\title{
WATER AND ENVIRONMENT
}

DOI: 10.1556/Novenyterm.59.2010.Suppl.3 


\title{
APPLICATION OF THE SMART MUTAGENICITY TEST AND AN AQUATIC TOXICITY BIOTEST ON PESTICIDES AS ENVIRONMENTAL STRESSORS
}

\author{
Kata BOKÁN ${ }^{1,2}$ - Ágnes FEJES ${ }^{1,3}$ - Gábor FEKETE ${ }^{1}$ \\ ${ }^{1}$ Department of Ecotoxicology and Environmental Chemistry, Plant Protection Institute, Hungarian Academy \\ of Sciences, H.1022 Budapest, Herman Ottó 15, Hungary. e-mail: bokan@julia-nki.hu \\ ${ }^{2}$ Szent István University, PhD School of Environmental Sciences, H-2103 Gödöllö, Páter K. u. 1, Hungary \\ ${ }^{3}$ University of Pannonia, Georgikon Faculty of Agriculture, Doctoral School in Animal and Agricultural \\ Environmental Sciences, H-8360 Keszthely, Deák F. u. 16, Hungary.
}

Abstract: Mutagenicity is a key biological effect environmental contaminants may exert. In our examinations groundwater samples - originating mainly from cereal fields - were analyzed. Mutagenicity was determined by application of the somatic mutation and recombination test (SMART). The test utilizes Drosophila melanogaster females carrying $m w h$ (multi wing hair) and males carrying flr (flare) recessive marker mutations. Homozygote $m w h$ cells grow 3-7 hairs in bundles, while flr homozygote cells form a single curly hair. Treated larvae derive from the hybridization of such parents. Larvae surviving the exposition of mutagens and developing into imagoes have possible mosaic patches on wings. As a new approach towards the practical application of the SMART test, the first step was to survey most frequent pesticides in Hungarian ground water samples. In parallel, aquatic toxicity biotests were carried out using the Daphina magna Straus. The most contaminated water samples, containing residues of acetochlor, atrazine, diazinon, metolachlor, terbutryn and/or trifluralin at levels of 0.18 to over $1000 \mathrm{ng} \mathrm{ml}^{-1}$ showed acute toxicity in the Daphnia magna test, but no mutagenic effect (mutation frequency was $<10^{-4}$ ) in the SMART test.

Keywords: mutagenicity tests, mutagenic, SMART test, pesticide, environmental sample, Drosophila melanogaster, aquatic toxicity, Daphnia magna

\section{Introduction}

Thousands of new synthetic compounds are produced annually. Several among them are mutagenic, and numerous are carcinogenic as well. The strong connection between carcinogenic and mutagenic substances makes it necessary to detect the mutagenic effects of compounds released into the environment. The living organisms do not have an opportunity to adapt to the quickly changing environment. It is proven, that almost $90 \%$ of the cancerous diseases are caused by the mutagens reaching the environment, especially via pesticides (Szabad, 1987). A quarter of the currently used pesticides show mutagenic effect in at least one of the accepted mutagenicity tests. The Somatic Mutation and Recombination test (SMART) test is highly suitable for screening genotoxic activity, as it is an easy and inexpensive test using a eukaryotic organism in vivo (Szabad et al, 1983) and provides a means to assess the potential of complex environmental samples (Jacociunas et al, 2010). This wing spot assay performed on mutant strains of the fruit fly, Drosophila melanogaster offers novel information on mutagenity beyond conventional bacterial test methods.

Certain groundwater samples, collected in environmental surveys in Hungary, showed high activity previously in the standardized Daphnia magna immobilization test for aquatic toxicity. Chemical analysis revealed that the samples contained pesticide residues (acetochlor, atrazine, metolachlor, terbutryn, trifluralin) in agreement with results of earlier water and soil contamination surveys (Anton et al, 2004; Székács et al, 2005; Oldal et al, 2006; Maloschik et al, 2007). To assess whether such pesticide 
contamination cause mutagenic effects in addition to toxicity to aquatic organisms, the samples were subjected to the SMART test.

\section{Materials and methods}

\section{Sample collection and preparation}

Groundwater samples were collected in June, 2009 from 2 industrial sites in Gyomaendrőd, Békés county, Hungary. Water sampling was carried out according to national standard MSZ ISO 5667 (Hungarian Standards Institution, 1995), from already existing groundwater monitoring wells. The samples examined were originated from wells at an industrial pollution site. Water samples were filtered and subjected to solid phase extraction (SPE) (Maloschik et al, 2007) using CarboPrep-90 SPE columns (500 $\mathrm{mg}, 6 \mathrm{ml}$ ). This absorbed material from $1000 \mathrm{ml}$ of water was eluted from the SPE column with dichloromethane/methanol evaporated to final volumes of $1 \mathrm{ml}$ upon solvent exchange.

\section{Immobilization test on Daphnia magna}

Aquatic biotests, using the giant water flea (Daphnia magna Straus), were carried out on water samples with highest contamination rates detected. Immobilization tests were performed according to the ISO 6341:1996 standard (International Organisation for Standardisation, 1996).

\section{Drosophila strains applied}

Virgin female and male fruit flies (Drosophila melanogaster) carrying recessive marker mutations on the 3. chromosome were collected from reared laboratory colonies. Females and males carried $m w h$ (multi wing hair) and flr (flare) mutations, respectively. The $m w h$ homozygote cells grow 3-7 hairs in bundles, while $\mathrm{flr}^{3}$ homozygote cells form a single curly hair. Both strains were obtained from Prof. J. Szabad (University of Szeged).

\section{Wing spot test}

D. melanogaster larvae treated with the samples of interest derived from the hybridization of the mutant parents. Larvae surviving the treatment and reaching imago stadium have possible mosaic patches on their wings. These mosaic spots have long been known to form on the cuticle of the adults if larvae from which they develop are exposed to different mutagens. Mosaic patches are rarely formed if the examined implement does not have a mutagenic effect. The mutagenic activity of the treatment should be reflected in an elevation in the mosaic spot frequency as compared to the control.

\section{Treatments}

From the crossed offspring, $72 \mathrm{~h}$ old larvae in their third embryonic stage were washed out from the vials and were transferred to prepared medium. Twelve larvae were placed in each prepared vial, with two repetitions at every concentration. All experiments were performed at $25 \pm 1^{\circ} \mathrm{C}$.

Adult flies were collected from treatment vials, their wings were removed and mounted in Faure's solution (30 g of gum arabic; $20 \mathrm{~mL}$ of glycerol, $1.5 \mathrm{~g}$ of chloral hydrate and $50 \mathrm{~mL}$ of distilled water) (Dias et al, 2009). The wings' dorsal and ventral surfaces 
were examined under a compound microscope at X400 magnification for the occurrence of mutant spots (clones) on the phenotypically wild type wing blade. Formaldehyde, causing easily detectable mutation, was used as a positive control.

\section{Statistical analysis}

The effectiveness of the potential mutagen is measurable by the mutation frequency (f). $f=n^{*} m / C^{*} N$, where $n$ is the number of the mosaic spots, $m$ is their average size, $N$ is the number of the examined wings and $C$ is the number of the cells in the wing blade, which is 30800 according to Garcio-bellido and Merriam (1971).

\section{Results and discussion}

Mutagenicity of surface waters in Hungary has been reported (Csanady and Straub, 1995). Although observed mutagenicity was linked to trihalomethanes, systematic screening for other mutagenic pollutants including 2,4-D, malathion and benzo(a)pyrene was urged. The role of environmental mutagens as soil contaminants has also been emphasized in general (Szende, 1982) and in relation to PCP (Hajdu et al, 2009).

Significant aquatic toxicity was detected in all water samples heavily contaminated with pesticide residues indicating that these contaminants do cause toxicity on D. magna. Even though the contaminated site the samples originated from has previously been cleaned-up from industrial pollution, chemical analysis still showed the samples severely contaminated with pesticides residues. Major contaminants were atrazine and acetochlor at concentrations of 0.18 to over $1000 \mathrm{ng} \mathrm{ml}^{-1}$, minor contaminants were diazinon, metolachlor, terbutryn and trifluralin at concentrations of 0.008-55.9 $\mathrm{ng} \mathrm{ml}^{-1}$, Samples polluted with acetochlor and atrazine caused full mortality in the D. magna biotest, when applied undiluted. These most contaminated water samples were measured in 5-, 10- and 25-fold dilutions as well, and it was found that $50 \%$ mortality $\left(\mathrm{EC}_{50}\right)$ was reached when the samples were applied at dilutions of 6.4- and 13.3-fold, respectively. The strong mortality caused by these samples was a clear result of synergistic effect of the individual contaminants, as the actual, although apparently high, levels were far below of the individual $\mathrm{EC}_{50}$ values. Henceforth some groundwater samples of high toxic activity in the previously applied Daphnia magna immobilization test were examined using the Drosophila wing spot test. The samples applied contained pesticides' active ingredients already investigated as pure compounds in the SMART test. Previous investigations identified that atrazine and glyphosate cause wing spot mosaicism at high concentration (Torres et al., 1992; Kaya et al, 2000). In contrast to these literature results, no mutagenic event was recorded in the SMART test with the above-mentioned pesticide contaminants, particularly with atrazine and acetochlor even above $1000 \mathrm{ng} \mathrm{ml}^{-1}$. The results obtained shows that mutation frequency of the groundwater samples in all cases were lower $\left(5.5^{*} 10^{-6}-1.9^{*} 10^{-5}\right)$ than in the case of formaldehyde used as positive control $\left(f=9 * 10^{-4}\right.$ ). Accordingly the examined environmental samples cannot be considered mutagenic in the SMART test.

\section{Conclusions}

The D. melanogaster wing spot test allows fast and reliable quantification of pesticides' active ingredients and groundwater samples to disturb the Drosophila somatic genome. 
No genotoxical events were identified with ground water samples containing residues of acetochlor, atrazine, diazinon, metolachlor, terbutryn and/or trifluralin at levels of 0.18 to over $1000 \mathrm{ng} \mathrm{ml}-1$, even though these residues caused considerable toxicity to the aquatic arthropod, Daphnia magna Straus. Toxicity on D. magna is mechanism-based as the key toxicant in this test, diazionon, is a neurotoxin. Nonetheless, the contaminants detected exert no mutagenic effect at the concentrations detected, and accordingly were not manifested in the SMART test. The present experiments illustrated that the SMART test is suitable not only for the investigations of mutagenicity by pure compounds, but is applicable for environmental samples as well.

\section{Acknowledgements}

This investigation was supported by research project MONTABIO (OM 00029/2008) by the National Office for Research and Technology of Hungary (NKTH JÁP).

\section{References}

Anton, A. - Oldal, B. - Székács, A.: 2004. Survey of pesticide active agents taken from different Hungarian soil reference points. In: Geophysical Research Abstracts, European Geosciences Union. SRef-ID: 16077962/gra/EGU04-A-07666, 6: 07666.

Csanady, M. - Straub, I.: 1995. Health damage due to water pollution in Hungary. In: Assessing and Managing Health Risks from Drinking Water Contamination: Approaches and Applications. IAHS Publ. 233: $147-152$.

Dias, C. D. - Araújo, B. C. - Dutra, E. S. - Nepomuceno, J. C.: 2009. Protective effects of beta-carotene against the genotoxicity of doxorubicin in somatic cells of Drosophila melanogaster. Genet. Mol. Res., 8(4): 1367-1375.

Garcia-Bellido, A. - Merriam, J. R.: 1971. Parameters of the wing imaginal disc development of Drosophila melanogaster. Dev Biol., 24(1): 61-87.

Hajdu, C. - Gruiz, K. - Fenyvesi, É.: 2009. Bioavailability- and bioaccessibility-dependent mutagenicity of pentachlorophenol (PCP). Land Contam. Reclam. 17 (3-4): 475-484.

Hungarian Standards Institution: 1995. Water quality. Sampling: Part 1. Guidance on the design of sampling programmes and sampling techniques (ISO 5667-1:2006). Hungarian Standard (MSZ ISO) 5667-6:1995

International Organisation for Standardisation: 1996. Water quality. Determination of the inhibition of mobility of Daphnia magna Straus (Cladocera, Crustacea) - acute toxicity test. ISO 6341:1996, Geneva, Switzerland

Jacociunas, L. V. - Dihl, R. R. - Lehmann, M. - Reguly, M. L. - de Andrade, H. H.: 2010. Recombinagenic activity of water and sediment from Sinos River and Araçá and Garças Streams (Canoas, Brazil), in the Drosophila wing spot test. Sci Total Environ.;408(3):571-577.

Kaya, B. - Creus, A. - Yanikoğlu, A. - Cabré, O. - Marcos, R.: 2000. Use of the Drosophila wing spot test in the genotoxicity testing of different herbicides. Environ. Mol. Mutagen., 36(1): 40-46.

Maloschik, E. - Ernst, A. - Hegedűs, Gy. - Darvas, B. - Székács, A.: 2007. Monitoring water polluting pesticides in Hungary. Microchem J, 85: 88-97.

Oldal, B. - Maloschik, E. - Uzinger, N. - Anton, A. - Székács, A.: 2006. Pesticide residues in Hungarian soils. Geoderma, 135: 163-178.

Szabad, J. - Soós, I. - Polgár, Gy. - Héjja, Gy.: 1983. Testing the mutagenicity of malondialdehyde and formaldehyde by the Drosophila mosaic and the sex-linked recessive lethal tests. Mutation Res., 113: 117-133.

Szabad, J.: 1987. Rákkeltő tényezők szürése muslica mozaikokkal. Tudomány, 2: 51-56.

Székács, A. - Ernst, A. - Juracsek, J. - Darvas, B.: 2005: Monitoring water polluting pesticides in Hungary. In: Elbestawy, E. - Moklyachuk, L. - Pidlisnyuk, V. - Schulz, N. - Stefanovska, T.- Vijgen, J. (eds), $7^{\text {th }}$ International $\mathrm{HCH}$ and Pesticides Forum Book. International $\mathrm{HCH} \&$ Pesticides Association, Holte, Denmark, 68-69.

Szende, K.: 1982. Environmental mutagens, ecological genetics and evolution. Mutation Res. 97: 225-226.

Torres, C. - Ribas, G. - Xamena, N. - Creus, A. - Marcos, R.: 1992. Genotoxicity of four herbicides in the Drosophila wing spot test. Mutat Res., 280(4): 291-295. 


\title{
APPLIED LAND CHANGE MODELLING BASED ON EXCESS WATER AFFECTED AREAS FOR AGRO-ECOLOGICAL SUSTAINABILITY ON THE SOUTHERN GREAT PLAIN
}

\author{
Csaba BOZÁN ${ }^{1}$ - János TAMÁS ${ }^{2}$ \\ ${ }^{1}$ Research Institute for Fisheries, Aquaculture and Irrigation, Hungary, H-5541 Szarvas, Anna-liget 8., e- \\ mail: bozancs@haki.hu \\ ${ }^{2}$ Department of Water- and Environmental Management, Faculty of Agronomy, Centre of Agriculture and \\ Engineering Sciences, University of Debrecen, Hungary, H-4032 Debrecen, Böszörményi út 138., e-mail: \\ tamas@gisserver1.date.hu
}

Abstract: Land-Use modeling is a rapidly growing scientific field because land-use changing is one of the most important ways that humans influence can cause for agro-environment. This paper presents a LCMIDRISI land-use change GIS model to plan and find the best compromise between land-use management and excess water affected areas. Simulation processes were as follows: 1) the data acquisition and quality evaluation, 2) the simulation model, and 3) the statistical techniques of goodness-of-fit. LCM is a grid-based land-use and land-cover change model, which simulates the spatial pattern of land change forwards or backwards in time, and it can produce an image of the cumulative environmental impact over the duration of the simulation. The output of LCM model is a map of the simulated landscape of among the cells zones at the ending time with spatial mask. The suitability map was created, by using several driver maps and the landcover map from the beginning time to calculate transitional potential and trend surfaces of categories. The predicted maps and scenarios can help decision makers, and it is being to help develop land-use strategies elsewhere in the agro-environment where a goal is to make approaches to the expected land management (agricultural planning, water management interventions, water oriented cultivation systems, wetland restoration etc.). The sustainable and rational land use needs continuous actions and permanent care for the maintenance of agro-ecosystems' resilience. The results of land change modeling may show those significant areas where there is a need to regulate or moderate the effects of extreme hydrological events and to minimize risks of soil degradation by enhancing its resilience.

Keywords: LCM, MLP, excess water inundation, gain and loss

\section{Introduction}

Land-Use modeling is a rapidly growing scientific field because land-use changing is one of the most important ways that humans influence can cause for agro-environment. For the sustainable utilization of the land ecosystems, it is essential to know the natural characteristics, extent and location, quality, productivity, suitability and limitations of various land uses (Rahman and Saha, 2009). The analysis of the spatial extent and temporal change of land-use categories using remotely sensed data is of critical importance to agricultural sciences (Tamás, 2003). The rational land-use and proper soil management are important elements of sustainable (agricultural) development, having special importance both in the national economy and in environmental protection (Várallyay, 2006). Space-born remote sensing has a good potential for change detection and good data availability and is, therefore, well suited for the monitoring of land-use change over a time period.

\section{Materials and methods}

In our study we examined the relation between CLC2000 (Source: FÖMI) and CLC2006 (Source: EEA EIONET) database. The CLC's have a working scale of 1:100000. CLC distinguishes different land-use classes which are mapped as a separate 
category (Büttner et al., 2001). The land cover classes were compared using a pixel based analysis approach to develop a land cover change map and net changes graphs based on pixel change values. The land change, driver, transition potentials and prediction maps were processed with the Land Change Model (LCM). The investigated area was the Southern Great Plain. We also compiled the map of relative frequency of excess water events. Its source was the yearly mapping of the areas damaged by maximal inundation from 1960 to 2006 . Relative frequency of excess water events can be determined by dividing number of excess water events by total number of examined years.

Spatial data were processed by IDRISI Andes 15.0 and ArcGIS 9.2.

\section{Results and discussion}

Gains and losses (Figure 1) are based on change of values between 2000 and 2006 land cover pixels and exclude pixels with no change. Values are shown in hectares some of the gains and/or losses are offset by pixel misclassification and generalization of cluster groups. The biggest gains are in the Pastures, Coniferous forest and Arable lands.

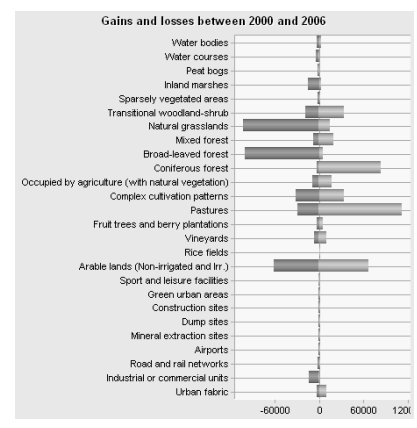

Figure 1. Land Cover Gains and Losses

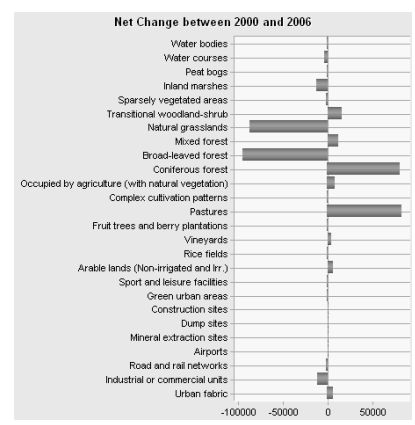

Figure 2. Land Cover Net Changes

The Land Cover Net Changes graphs (Figure 2) show the total net changes in hectares for the 26 land cover classes. The graph shows the Natural Grassland and the Broadleaved Forest areas have declined more than 25.000 hectares and the Coniferous Forest and the Pastures areas have increased more than 23.000 hectares. According to the land cover change map the changes are based on a pixel value change analysis. Detail land cover changes are shown on the legend. Pixels with no change have been assigned a nodata value and are not shown on the legend. The most noticeable changes are in the Natural Grassland, Arable Lands, Complex Cultivation Patterns and Broad-leaves Forest which is shown in sample size (Figure 3). The next step is to create a group transitions into a set of sub-models and to explore the potential power of explanatory variables. Static variables express aspects of basic suitability for the transition under consideration, and are unchanging over time. According to the results of running LCM model the number of transitions was high so it was reduced to just 4 transitions (ignore transitions less than $15.000 \mathrm{ha}$ ). In order to predict changes, we will need (at any moment in time) to be able to create a map of the potential of land to go through each of these transitions so called transition potential maps. 


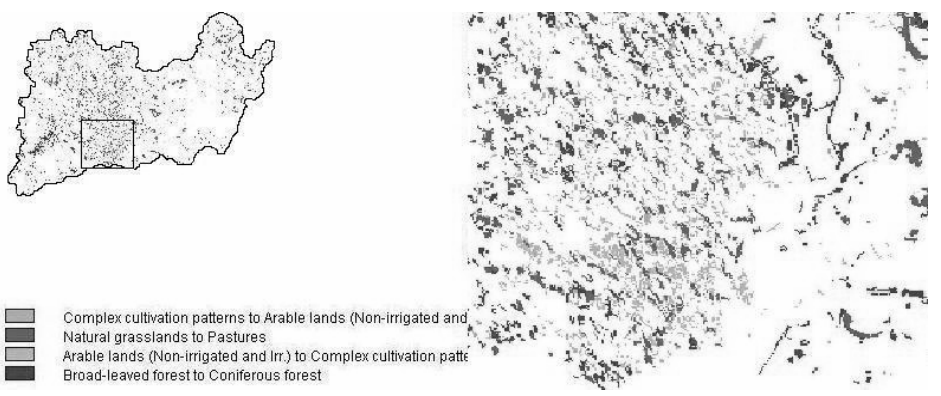

Figure 3. Land cover change map

The evidence likelihood transformation is a very effective means of incorporating categorical variables into the analysis. It was created by determining the relative frequency with which different land cover categories occurred within the areas that transitioned from 2000 to 2006. The numbers thus express the likelihood of finding the land cover at the pixel in question if this were an area that would transition. According to the high Cramer's V values the broad-leaved forest, the complex cultivation patterns and the rice fields have a strong association with all categories. The driver map was selected for the LCM model. It was used for creation the distance map from 4-times frequency of excess water inundation (Figure 4).

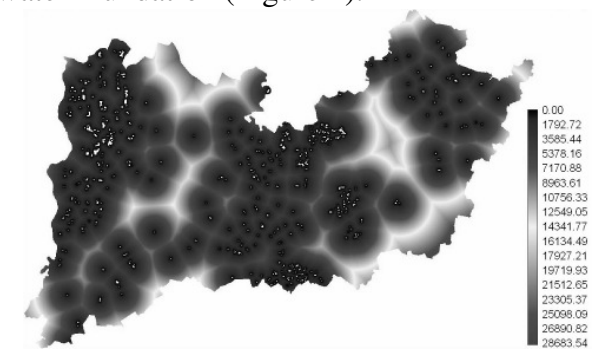

Figure 4. Distance from 4-times frequency of excess water inundation

Each transition was modeled using Multi-layer Perceptron (MLP) neural network which is a dynamic process. The MLP constructs a network of neurons between explanatory variables and output classes (the transitions and persistence classes), and a web of connections between the neurons that are applied as a set of (initially random) weights. These weights structure the multivariate function. When the MLP completes its training, it is up to us to decide whether it has done well enough and whether it should re-train either with the same parameters, but a different random sample, or with new parameters. As launched by LCM IDRISI, the MLP starts training on the samples it has been provided of pixels that have and have not experienced the transitions being modeled. At this point, the MLP is operating in automatic mode whereby it makes its own decisions about the parameters to be used and how they should be changed to better model the data. After training has been completed, we need to classify to complete the process of transition potential modeling. The result in either case is a transition potential map for each transition (Figure 5). 


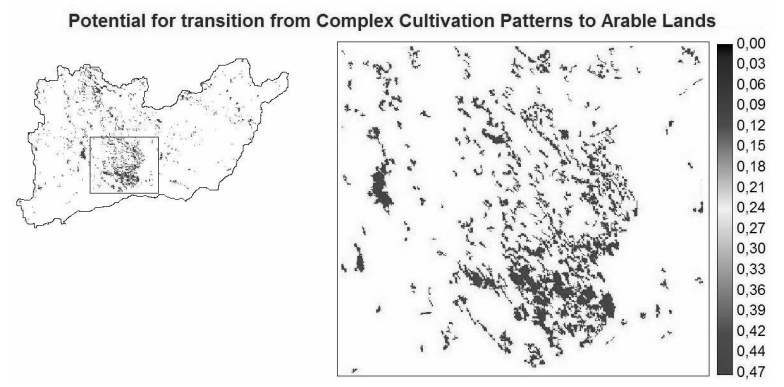

Figure 5. Transition potential map (sample)

If we want to determine the potential of land transform (Figure 6), we may consider the distance to excess water hazarded areas.

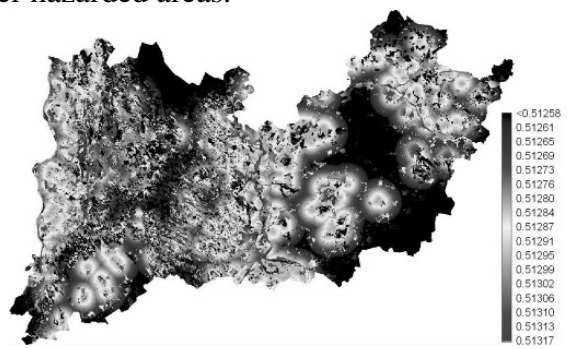

Figure 6. Soft prediction to land transforms

\section{Conclusions}

One of the major components of land cover change prediction is modeling transition potential. According to the LCM IDRISI the primary tool for transition potential modeling is the MLP Neural Network. In LCM, land cover change prediction utilizes two land cover maps from two different dates (2000 and 2006) to predict what the land cover will be in the future or what land cover need to transform in the future. The particular transitions of interest were specified for the sub-model and specified a variable which drive the type of transition taking place. As a consequence the resulted maps and the integrated database can be utilized in numerous land related activities (e.g. land-use and agricultural planning).

\section{References}

Büttner, G. - Bíró, M. - Maucha, G. - Petrik, O.: 2001. Land cover mapping at scale 1:50.000 in Hungary: Lessons learnt from the European CORINE programme, in: A decade of Trans-European Remote Sensing Cooperation, Buchroithner, M.F. (Ed.), Balkema. 25-31.

Rejmur Rahman, Md. - Saha, S. K.: 2009. Spatial dynamics of cropland and cropping pattern change analysis using Landsat TM and IRS P6 LISS III satellite images with GIS. Geo-spatial Information Science, 12 (2): 123-134.

Tamás, J.: 2003. Problems and solutions of field scale agro-ecological data acquisition and data interpretations in agroinformatical domain. Applied Ecology and Enviromental Research, International Scientific Journal, 1 (1-2). 143-159.

Várallyay, Gy.: 2006. Soil degradation processes and extreme soil moisture regime as environmental problems in the Carpathian Basin. Agrokémia és Talajtan, 55 (1-2): 9-18. 


\title{
ASSIGNMENT OF HYDROLIMITS FOR ESTIMATION OF SOIL ABILITY TO SUPPLY PLANTS BY WATER
}

\author{
Vlasta ŠTEKAUEROVÁ ${ }^{1}-$ Jana SKALOVÁ ${ }^{2}-$ Katarína NOVÁKOVÁ $^{3}$ \\ ${ }^{1}$ Institute of Hydrology, Slovak Academy of Sciences, Račianska 75, 83102 Bratislava, Slovakia, \\ stekauer@uh.savba.sk \\ ${ }^{2}$ Department of Land and Water Resources Management, Faculty of Civil Engineering, Slovak University of \\ Technology, Radlinského 11, 81368 Bratislava, Slovakia, jana.skalova@stuba.sk \\ ${ }^{3}$ Soil Science and Conservation Research Institute, Gagarinova 10, 82713 Bratislava, Slovakia, \\ k.novakova@vupop.sk
}

Abstract: The plants are supplied by water from soil aeration zone. It is necessary to know the water amount that the soil can provide to the plants. The hydrolimits can by used for estimation of water storage for plants need. They are soil water contents defined for certain values of soil water potentials. There are three very important hydrolimits. $\Theta_{\mathrm{FC}}-$ field capacity is defined for interval of soil water potentials $-\mathrm{pF}(2.0 ; 2.7), \Theta_{\mathrm{PDA}}$ - point of decreased of availability for interval - $\mathrm{pF}$ (3.0;3.3) and $\Theta_{\mathrm{WP}}-$ wilting point is defined for soil water potentials $-\mathrm{pF}=4.18$. The variability of each hydrolimit in said interval expresses kind of plant. The hydrolimits can be found by various ways. It is very important to obtain these characteristics for various kind of soil or the best for catchment. To obtain the hydrolimits from soil water retention curves is the best way. Aim of the study is to calculate values of above mentioned hydrolimits using pedotransfer function that were devised from soil water retention curves that were measured for soils of Morava river chatment (Slovak side). The hydrolimits calculated this way are compared to hydrolimits values from another measured soil moisture retention curves. Suitability of the method for its use in practice is verified.

Keywords: soil, water, retention curve, pedotransfer function

\section{Introduction}

Soil water regime, which determines its production ability, depends on inflow into or outflow from the area. Considering the fact that plants are supplied by water from the soil aeration zone, it is necessary to know the water amount that the soil can provide the plants with (Klupács et al, 2009.; Nagy and Igaz, 2009). The water storage in the soil aeration zone reacts to climate changes and to antropogenic activity realised within the area from the long-term point of view (Szolgay et al., 2009; Mikulec and Stehlová, 2006; Horváth et al., 2007). For estimation of water storage in the soil aeration zone in relation to plants the hydrolimits can be used.

Hydrolimits are soil water contents defined for certain values of water potentials. Closer attention is paid to three hydrolimits: $\Theta_{\mathrm{FC}}-$ field capacity is defined for interval of soil water potentials $\mathrm{pF}(2.0 ; 2.7)$ in $\mathrm{cm}$ it is $\left(10^{2.0} ; 10^{2.7}\right)$, $\Theta_{\mathrm{PDA}}-$ point of decreased availability for $\mathrm{pF}(3.0 ; 3.3)$ and $\Theta_{\mathrm{WP}}$ wilting point for $\mathrm{pF}=4.18$. The hydrolimits can be find out by various ways. Use of soil water retention curves for reading of hydrolimit values for respective water potentials is one from possibility to obtain theirs values. The problem of hydrolimit assessment is concentrated on assessment of water retention curve.

Measuring of the dependence $h_{w}(\Theta)$ is expensive and time demanding. An obvious relationship between $h_{w}(\Theta)$ and soil texture has led to formulation of models that are trying to put into relation e.g. sand, clay, loam and dry bulk density with $h_{w}(\Theta)$, etc. and they are generally called pedotransfer functions (PTFs) (Pachepsky - Rawls, 2004). 
Aim of the study is to calculate values of above mentioned hydrolimits using pedotransfer functions that were devised from a data file of water retention curves measured for soil samles from Morava chatment. The hydrolimits calculated this way are compared to hydrolimit values determined from another measured water retention curves. Suitability of the method for its using in practice is verified this way.

\section{Materials and methods}

Water retention curves of the Morava chatment soils were determined under laboratory conditions using overpressure apparatus. The data set contained drying branches of water retention curves (WRCs) from 43 soil samples. Volumetric water contents were determined at water potentials of $-3,-60,-200,-560,-1000$ and $-3000 \mathrm{~cm}$, particle size distribution was determined by Cassagrande's method for each sample as well as bulk density $\rho_{\mathrm{d}}$ and humus.

From these soil samples pedotransfer functions (PTFs) were obtained by fivetuple linear regression for soil volume water contents $\Theta_{\mathrm{hw}}$ at above mentioned soil water potentials $\mathrm{h}_{\mathrm{w}}$ depending on percentage content of category particles I $(d<0.01 \mathrm{~mm})$, II $(0.01 \mathrm{~mm}<$ $d<0,05 \mathrm{~mm})$, III $(0.05 \mathrm{~mm}<d<0,1 \mathrm{~mm})$, on dry bulk density $\rho_{\mathrm{d}}\left(\mathrm{g} . \mathrm{cm}^{-3}\right)$ and percentage content of humus ( $d$ is diameter of particles). Resultant PTFs have the general form:

$\Theta_{\text {hw }}=\mathrm{A}($ III.cat $)+\mathrm{B}($ II.cat $)+\mathrm{C}($ I.cat $)+\mathrm{D} \rho_{\mathrm{d}}+\mathrm{E}($ humus $)+\mathrm{F}$

where A, B, C, D, E, F are regression coefficients, I., II. and III. grain categories are presented in $\%$ and humus in $\%$, too. Regression coefficients $\mathrm{A}, \mathrm{B}, \mathrm{C}, \mathrm{D}, \mathrm{E}, \mathrm{F}$ are presented in Table 1 for all water potentials together with a correlation coefficient $\mathrm{R}$.

Table 1. Coefficients A, B, C, D, E, F of regression relations and correlation coefficient $\mathrm{R}$ for pedotransfer functions where $\mathrm{h}_{\mathrm{w}}$ is soil moisture potential

\begin{tabular}{|c|c|c|c|c|c|c|c|}
\hline $\mathrm{h}_{\mathrm{w}}$ & \multicolumn{5}{|c|}{ Coefficients of regression relations } & $\begin{array}{c}\text { correlation } \\
\text { coefficient }\end{array}$ \\
\hline$[\mathrm{cm}]$ & $\mathrm{A}$ & $\mathrm{B}$ & $\mathrm{C}$ & $\mathrm{D}$ & $\mathrm{E}$ & $\mathrm{F}$ & $\mathrm{R}$ \\
\hline \hline-1 & 0,00362 & 0,00066 & 0,00119 & $-0,29625$ & 0,00014 & 0,79648 & 0,95343 \\
-60 & 0,00896 & 0,00104 & 0,00229 & $-0,10879$ & 0,03398 & 0,27547 & 0,94669 \\
-200 & 0,00695 & 0,00161 & 0,00259 & $-0,04853$ & 0,04200 & 0,12051 & 0,94507 \\
-560 & 0,00567 & 0,00178 & 0,00272 & $-0,01197$ & 0,04481 & 0,03037 & 0,94522 \\
-1000 & 0,00489 & 0,00166 & 0,00259 & $-0,00135$ & 0,04873 & 0,00300 & 0,94252 \\
-3000 & 0,00447 & 0,00137 & 0,00274 & 0,05599 & 0,04888 & $-0,11906$ & 0,93914 \\
\hline
\end{tabular}

A value of residual moisture $\Theta_{\mathrm{r}}$ was calculated for the soil samples using the relation (Š́útor, Majerčák, 1988): $\Theta_{\mathrm{r}}=0,20058$ (\% I.cat) $+1,03747$.

A new data file of WRCs measured in 9 soil samples was obtained from congenerous localities from which the data file of original 43 WRCs was obtained. The WRCs of the 9 samples were measured using the same above-mentioned method for the same soil water potentials, particle size distributions of soil samles were determined as well as bulk density $\rho_{\mathrm{d}}$ and humus. The points of each from 9 WRC were approximated by van Genuchten's relations (1980) and coefficients $a_{m}$ and $n_{m}$ were obtained. The $m$ is mark for coefficients obtained for measured WRCs. The data file of the approximated WRCs 
was labelled as $S_{m}$. Than point values of $\mathrm{WRC}$ at water potentials of $-3,-60,-200,-560$, -1000 and $-3000 \mathrm{~cm}$ were calculated from the PTFs fumction (eq.1, Table 1). The above-mentioned point values were also approximated according to van Genuchten and thereby the coefficient values $\alpha_{P T F}$ and $n_{P T F}$ were obtained. The PTF index means that the coefficients obtained for WRC were calculated using PTFs. The file of approximated WRC was labelled as $\mathrm{S}_{\mathrm{PTF}}$. The hydrolimits field capacity $\Theta_{\mathrm{FC}}$, point of decreased availability $\Theta_{\mathrm{PDA}}$ and the wilting point $\Theta_{\mathrm{WP}}$ were determined from the WRC approximated according to van Genuchten for both files $S_{m}$ and $S_{P T F}$.

\section{Results and discussion}

Main parameters obtained by approximation of WRCs using the van Genuchten relation for both files $S_{\mathrm{m}}$ and $\mathrm{S}_{\mathrm{PTF}}$ are presented for 9 soil samples A1 - A9 (Table 2).

$\Theta_{\mathrm{FC}}, \Theta_{\mathrm{PDA}}$ and $\Theta_{\mathrm{WP}}$ for mean values of water potentials namely for $\mathrm{pF} \mathrm{F}_{\mathrm{FC}}=2.5, \mathrm{pF}_{\mathrm{PDA}}=$ 3.3 and $\mathrm{pF}_{\mathrm{WP}}=4.18$ were obtained from water retention curves from the file $\mathrm{S}_{\mathrm{PTF}}$ and from measured WRCs (the file $S_{\mathrm{m}}$ ). The results are presented in Table 3.

Table 2. Basic parameters of the WRCs obtained by approximation by van Genuchten relation $(\alpha, \mathrm{n})$. Sm

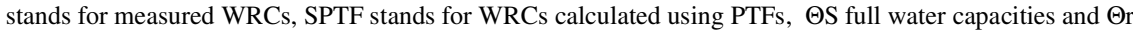
residual volume water contents are equal for both files. MD and RMSD for comparison of the measured values with the calculated values of WRCs

\begin{tabular}{|c|c|c|c|c|c|c|c|c|c|}
\hline WRC & & $\mathrm{S}_{\mathrm{m}}$ & & & $\mathrm{S}_{\mathrm{PDF}}$ & & & \multicolumn{1}{c|}{$\mathrm{MD}$} & $\mathrm{RMSD}$ \\
\hline & $\alpha_{\mathrm{m}}$ & $n_{\mathrm{m}}$ & $\Theta_{\mathrm{S}}$ & $\alpha_{P D F}$ & $n_{P D F}$ & $\Theta_{\mathrm{s}}$ & $\Theta_{\mathrm{r}}$ & $\mathrm{m}^{3} \mathrm{~m}^{-3}$ & $\mathrm{~m}^{3} \mathrm{~m}^{-3}$ \\
\hline \hline A1 & 0,0753 & 1,1282 & 0,3713 & 0,0844 & 1,1043 & 0,3638 & 0,1143 & 0,0043 & 0,0081 \\
$\mathrm{~A} 2$ & 0,0116 & 1,1200 & 0,4652 & 0,0162 & 1,0998 & 0,4711 & 0,1179 & 0,0072 & 0,0081 \\
$\mathrm{~A} 3$ & 0,0283 & 1,1267 & 0,3988 & 0,0455 & 1,1158 & 0,3964 & 0,0870 & $-0,0057$ & 0,0068 \\
$\mathrm{~A} 4$ & 0,0410 & 1,0899 & 0,3856 & 0,0312 & 1,1104 & 0,3849 & 0,0752 & $-0,0068$ & 0,0089 \\
$\mathrm{~A} 5$ & 0,0174 & 1,1678 & 0,2628 & 0,0633 & 1,1355 & 0,2759 & 0,0568 & $-0,0009$ & 0,0089 \\
$\mathrm{~A} 6$ & 0,0591 & 1,2339 & 0,3288 & 0,1010 & 1,1904 & 0,3191 & 0,0350 & $-0,0021$ & 0,0092 \\
$\mathrm{~A} 7$ & 0,0160 & 1,1944 & 0,4486 & 0,0364 & 1,1531 & 0,4578 & 0,0836 & 0,0014 & 0,0088 \\
A8 & 0,0893 & 1,1666 & 0,3414 & 0,1137 & 1,1685 & 0,3586 & 0,0525 & 0,0045 & 0,0074 \\
A9 & 0,0351 & 1,2314 & 0,3224 & 0,0918 & 1,1906 & 0,3230 & 0,0397 & $-0,0079$ & 0,0122 \\
\hline
\end{tabular}

Table 3. Hydrolimits calculated from WRCs approximated using van Genuchten relation for both files $\mathrm{S}_{\mathrm{m}}$ and $S_{\mathrm{PTF}} \Theta_{\mathrm{FC}}$ - field capacity, $\Theta_{\mathrm{PDA}}$ - point of decreased availability, $\Theta_{\mathrm{WP}}$ - wilting point. $\Delta$ is difference between hydrolimit values from the files $S_{\mathrm{m}}$ and $\mathrm{S}_{\mathrm{PTF}}$

\begin{tabular}{|c|c|c|c|c|c|c|c|c|c|}
\hline & & $\mathrm{S}_{\mathrm{m}}$ & & & $\mathrm{S}_{\mathrm{PTF}}$ & & $\Delta=$ & $\mathrm{S}_{\mathrm{PTF}}-\mathrm{S}_{\mathrm{m}}$ & \\
\hline $\mathrm{WRC}$ & $\Theta_{\mathrm{FC}}$ & $\Theta_{\mathrm{PDA}}$ & $\Theta_{\mathrm{WP}}$ & $\Theta_{\mathrm{FC}}$ & $\Theta_{\mathrm{PDA}}$ & $\Theta_{\mathrm{WP}}$ & $\Theta_{\mathrm{FC}}$ & $\Theta_{\mathrm{PDA}}$ & $\Theta_{\mathrm{WP}}$ \\
\hline & $\mathrm{pF}=2.5$ & $\mathrm{pF}=3.3$ & $\mathrm{pF}=4.18$ & $\mathrm{pF}=2.5$ & $\mathrm{pF}=3.3$ & $\mathrm{pF}=4.18$ & $\mathrm{pF}=2.5$ & $\mathrm{pF}=3.3$ & $\mathrm{pF}=4.18$ \\
\hline $\mathrm{A} 1$ & 0.2849 & 0.2494 & 0.2186 & 0.2910 & 0.2604 & 0.2326 & 0.0061 & 0.0110 & 0.0140 \\
$\mathrm{~A} 2$ & 0.4084 & 0.3553 & 0.3046 & 0.4138 & 0.3671 & 0.3219 & 0.0054 & 0.0118 & 0.0173 \\
$\mathrm{~A} 3$ & 0.3210 & 0.2738 & 0.2316 & 0.3131 & 0.2705 & 0.2322 & -0.0079 & -0.0033 & 0.0006 \\
$\mathrm{~A} 4$ & 0.3205 & 0.2839 & 0.2493 & 0.3139 & 0.2713 & 0.2321 & -0.0066 & -0.0126 & 0.0172 \\
$\mathrm{~A} 5$ & 0.2087 & 0.1702 & 0.1377 & 0.2022 & 0.1705 & 0.1432 & -0.0065 & 0.0003 & 0.0055 \\
$\mathrm{~A} 6$ & 0.1824 & 0.1313 & 0.0950 & 0.1815 & 0.1384 & 0.1053 & -0.0009 & 0.0071 & 0.0103 \\
$\mathrm{~A} 7$ & 0.3442 & 0.2693 & 0.2092 & 0.3391 & 0.2776 & 0.2260 & -0.0051 & 0.0083 & 0.0160 \\
$\mathrm{~A} 8$ & 0.2176 & 0.1743 & 0.1394 & 0.2195 & 0.1752 & 0.1397 & 0.0019 & 0.0009 & 0.0003 \\
$\mathrm{~A} 9$ & 0.2001 & 0.1453 & 0.1059 & 0.1884 & 0.1446 & 0.1110 & -0.0117 & -0.0007 & 0.0051 \\
\hline
\end{tabular}


A close agreement is evident when comparing WRC measured and calculated using PTFs. Accuracy of the calculated WRCs is quantified with the mean difference (MD) and with the root of mean squared difference (RMSD). MD and RMSD are calculated from equations:

$$
M D=\frac{1}{6} \sum_{1}^{6}\left(\left(\theta_{h w i}\right)_{P D F}-\left(\theta_{h w i}\right)_{m}\right) \quad R M S D=\left[\frac{1}{6} \sum_{1}^{6}\left(\left(\theta_{h w i}\right)_{P D F}-\left(\theta_{h w i}\right)_{m}\right)^{2}\right]^{1 / 2} \text {, }
$$

where $h_{w i}=-3,-60,-200,-560,-1000$ and $-3000 \mathrm{~cm}$ for $\mathrm{i}=1,2, \ldots 6$.

The results of MD and RMDS values for soil samples A1 - A9 are in the Table 2 and RMSD values occur between 0,68 and $1,22 \%$ of the volume water content.

Difference between values of the hydrolimit $\Theta_{\mathrm{FC}}$ from data files $\mathrm{S}_{\mathrm{m}}$ and $\mathrm{S}_{\mathrm{PTF}}$ ranges from 0,09 to $1,17 \%$ of the volume water content, for $\Theta_{\mathrm{PDA}}$ it is from 0,03 to $1,26 \%$ and in case of $\Theta_{\mathrm{WP}}$ from 0,03 to $1,73 \%$ for all the cases.

\section{Conclusions}

Pedotransfer functions (PTFs) were obtained from 43 drying branches of water retention curves (WRC). The PTFs were used for a calculation of 9 WRCs that were measured too and were not included in the foregoing data file. The WRCs were approximated using van Genuchten relation in the both cases. Table 2 clearly demonstrate a close agreement for all 9 WRCs. Measured and calculated WRC were used for hydrolimit values assessment of the field capacity $\Theta_{\mathrm{FC}}$, point of decreased availability $\Theta_{\mathrm{PDA}}$, and the wilting point $\Theta_{\mathrm{WP}}$. It was found out, that differences between $\Theta_{\mathrm{FC}}$ and $\Theta_{\mathrm{PDA}}$ determined from approximated WRCs measured and calculated from PTFs did not exceed $1.26 \%$ of volume water content and a difference $\Theta_{\mathrm{WP}}$ did not exceed $1.73 \%$.

The presented study documents an efficiency and promptness of PTFs using for a region of interest for dynamics evaluation of water storage in the soil aeration zone considering the water supply of plants.

\section{Acknowledgements}

The authors would like to express theirs thanks to projects: VEGA (2/0120/08, 1/0319/09 and 1/0585/08) and APVV-0271-07.

\section{References}

Horváth E. - Farkas Cs. - Flachner Zs. - Tóth E. - Bakacsi Zs.: 2007. Analysing Soil hydraulic properties in the Bodrogközregion for supporting sustainable landuse. Cereal Research Communications, 34: 45-48

Klupács, H. - Nyárai, F.H. - Balla, I. - Jolánkai, M.: 2009. Water availability - a stressor influencing quantity and quality of winter wheat Triticum aestivum L. Yield. Cereal Research Communications, 37. 361-364.

Mikulec V. - Stehlová K.: 2006. Application of the climate change scenarios on selected meteorological characteristics for the purpouses of water content course prognosis in time horizons 2010, 2030 and 2075. Cereal Research Communications, 35: 485-488.

Nagy, V. - Igaz, D.: 2009. Use of the gravimetric and TDR methods for characterizing soil water storage stress for the vegetation. Cereal Research Communications, 37: 481-484

Pachepsky Ya. - Rawls W.J.: 2004. Development of pedotransfer functions in soil hydrology. Development in soil science. Amsterdam, Elsevier, 30: 512

Szolgay, J. - Hlavčová, K. - Parajka, J. - Lapin, M. - Kohnová, S. - Hlásny, T.: 2009. Climate Change Impact on Runoff in the Hron River Basin. Key Publishing, Ostrava, 116 


\title{
CHANGES IN WATER MANAGEMENT STRATEGY AS THE WAY FOR INCREASING OF AGRO-ECOSYSTEMS RESILIENCE TOWARDS DROUGHT
}

\author{
Viliam BÁREK ${ }^{1}$ - Ján ČIMO ${ }^{2}$ - Jozef ŽEMBERY ${ }^{5}$ - Denisa HALAJOVÁ ${ }^{4-}$ \\ Lucia TÁTOŠOVÁ ${ }^{3}$ \\ ${ }^{1}$ Department of Landscape Engineering, Faculty of Horticulture and Landscape Engineering, Slovak \\ University of Agriculture, Hospodárska 7, Nitra, Slovakia, e-mail: viliam.barek@ uniag.sk \\ ${ }^{2}$ Department of Biometeorology and Hydrology, Faculty of Horticulture and Landscape Engineering, Slovak \\ University of Agriculture \\ ${ }^{3}$ Department of Landscape Planning and Land Consolidation, Faculty of Horticulture and Landscape \\ Engineering, Slovak University of Agriculture \\ ${ }^{4}$ Department of Garden and Landscape Architecture, Faculty of Horticulture and Landscape Engineering, \\ Slovak University of Agriculture \\ ${ }^{5}$ Department of Plant Production, Faculty of Agrobiology and Food Resources, Slovak University of \\ Agriculture
}

\begin{abstract}
Acceleration of climate change may cause instability of most agricultural and forest ecosystems, including soil-ecological ecosystem. These changes will cause change of productive and environmental functions of soil cover, which may influence many Slovak regions, especially the south region. However, in some cases these changes may have positive effect on production potential of biomass production if there is properly regulated moisture regime. Assessment of irrigation water sources is determined by water balance in the basins. Balanced state of these ecosystems guaranteed sustainable development also for agriculture sectors as the largest consumer of water. Signs of climate change over the past 20 years bring instability into this sector, which consequently influence agricultural production and the ecosystem as a unit. Irrigation is one of the main adaptative measures on climate change (decrease of runoff from the basin, reducing of groundwater levels, and decrease of soil moisture). Current methods of water demand balancing of plants are not adequate in conditions of Slovak Republic. This paper shows determination of plants water demand according to FAO methodology (Penman - Montieh method of ET0 calculation) using outputs of scenarios of GISSmod and CCCMmod for time horizons of years 2030, 2075 and 2100. Target classes are field crops, vegetable, and special crops for conditions of the Slovak Republic. There was used DAISY model for changes simulation.
\end{abstract}

Keywords: climate change, irrigation, vegetables and special plants, production potential

\section{Introduction}

Changes of temperature, rainfall totals, but also other factors of the environment often change the time course of the plants live, i. e. beginning of the phenophases and by this also the duration of the phenophase intervals and the whole duration of vegetative periods of the individual plants (Parry et al., 2005). This scenario predicts the basic indicators of the agro-climatic relationships of the main vegetative period as for example increase of daily temperature sums (by 32 up to $55 \%$ ), photosynthetic active radiation increase by 10 up to $25 \%$, evapotranspiration increase in the south of Slovakia up to $20 \%$. Earlier onset and delay of phenophases ending is valid for vegetative periods, limited by the physiologic important temperatures to the time horizons of year 2100. It is assumed an increase of biomass production potential by $10 \%$ in the south region of Slovakia, and by $25 \%$ in the north region of Slovakia up to time horizon 2100. It is assumed that fully rentable cornflake cultivar will shift to altitudes up to 500 $\mathrm{m}$ a. s. 1. and the rentable cornflake cultivar will shift up to $800 \mathrm{~m}$ a. s. 1. (Šiška et al., 2002). 
Monitoring of the hydrologic series and actualized hydrologic scenarios (according to new climate scenarios) showed that there is a high probability to expect the general decrease of all three water resources in the future: surface, ground and soil. According to evaluation of total hydrologic situation in Slovakia for the last pentade can be stated that the extremeness partly increased, while the values assessed for the main Slovakian river basins didn't change significantly for the last years, compared to long-time averages. The years from 1996 up to 2000 belonged to the period with the highest ammouts of floods. These floods were from the river systems as well as from the storms which occurred generally on the relative small areas (Lapin et al., 1997; Lapin, 2004).

\section{Materials and methods}

There was used total water consumption Vc calculation according to Slovak technical standard STN 83 0635. The total water consumption Vc is an amount of water, which is necessary for evaporation, what assures the supposed development and the plant growth in given climate conditions and also ensures the other factors of growth during the whole vegetative period. The processes of evaporation and transpiration are influenced by weather, crop characteristics, management practices, and by environmental aspects. Actual evapotranspiration is also influenced by crop type, its variety and phenological development of crop. Evapotranspiration differs from reference evapotranspiration if soil cover, vesture properties and aerodynamic resistance of crop are different compared to the grass. Potential evapotranspiration $\mathrm{ET}_{\mathrm{c}}$ i.e. crop evapotranspiration under standard conditions (Allen et al., 1998) is evapotranspiration of healthy, well manured crop which is grown on large area under optimal soil water content reaching full production in given climate condition. Irrigation need represents the difference between moisture demand of crop and effective precipitation. Actual evapotranspiration $\mathrm{ET}_{\mathrm{a}}$, i.e. evapotranspiration under non-standard condition (Allen et al., 1998), is evapotranspiration from crop grown under farming management and natural conditions, which defers from standard conditions. Evapotranspiration derives from reference evapotranspiration, if the surface cover, vesture properties and crop aerodynamic resistance are different compared to the grass. Influence effect of different vesture characteristic of concrete crop on its evapotranspiration $E T_{c}$ is included into the crop coefficient $K_{c}: E T_{c}=K_{c} . E T_{0}$.

Daily climate data series (global radiation, air temperature, rainfall) for climatic station Hurbanovo were processed into required input data sets for numerical simulation by model DAISY. Software DAISY (Hansen et al., 1990) represents one dimensional numerical modeling tool for crop production assessment, soil water dynamics and nitrogen dynamics for different strategies of crop production management. Particular phenomena included in model are described by transport and transformation processes of water, heat, carbon and nitrogen. We carried out series of simulation using DAISY model for representative time period of years 1966-1985 (without assumption of climate change influence) and for climate change scenarios $\mathrm{CCCM}_{\text {prep }}$, GISS $\mathrm{S}_{\text {prep }}$ for time horizons of years, 2030, 2075 and 2100 for climatic station Hurbanovo. We used meteorological input data (global radiation, air temperature and rainfall) for 20 years time series with daily time step. 


\section{Results and discussion}

Results analysis showed indisputable limitation of recently used methodology in Slovak irrigation practice for climate change scenarios for time horizon of year 2100. This study introduce results of simulated potential evapotranspiration (ETo) using DAISY model for scenarios CCCMprep a GISSprep for time horizons of years 2030, 2075 and 2100 .

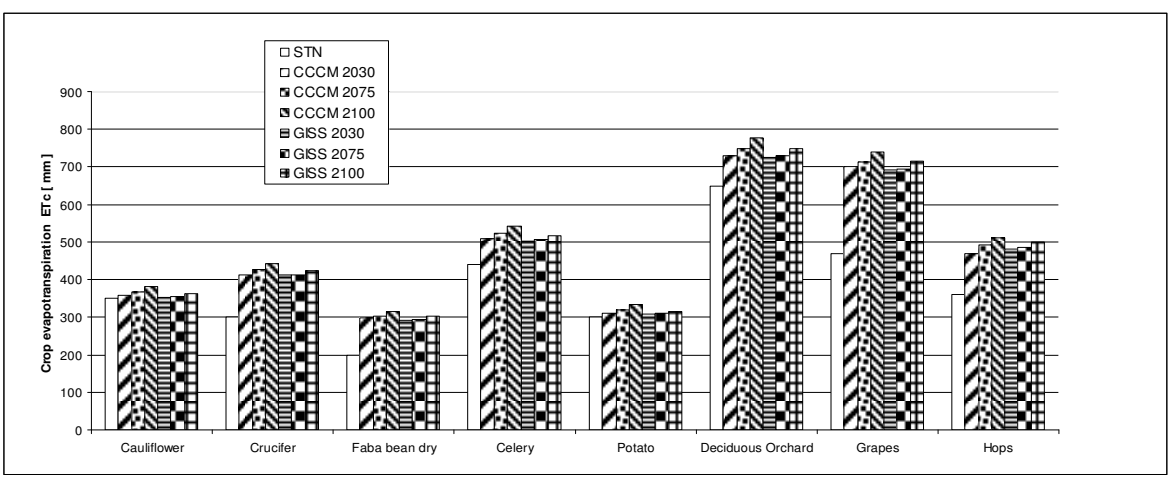

Figure 1. Comparison of consumptive water usage $\mathrm{V}_{\mathrm{c}}$ for selected special crops according to STN 830635 with simulated values of potential evapotranspiration $\mathrm{ET}_{0}$ according to $\mathrm{FAO}$ methodology for time horizons of years 2030, 2075 and 2100 for scenarios CCCMprep a GISSprep

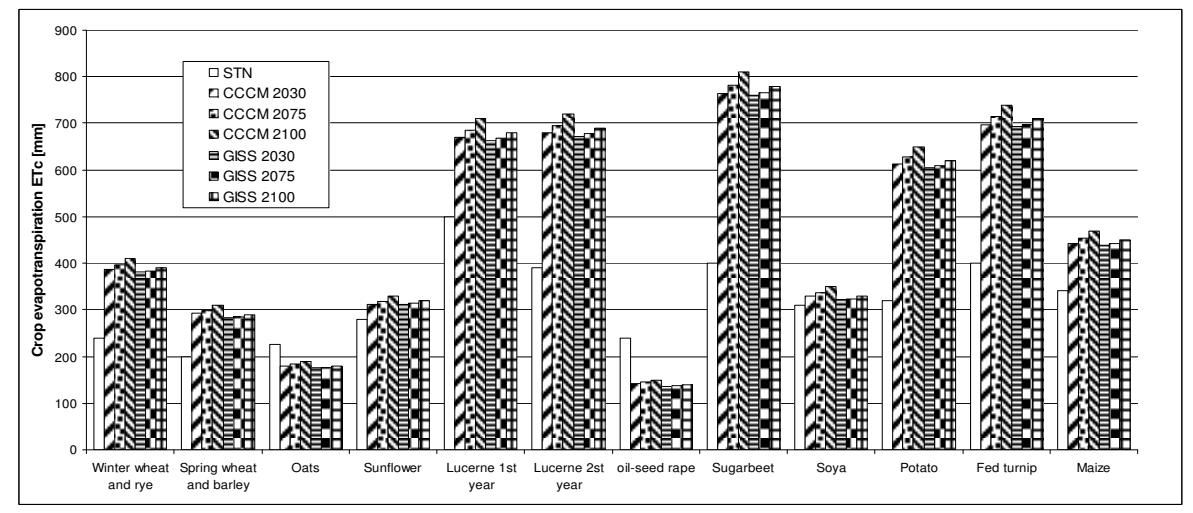

Figure 2. Comparison of consumptive water usage $\mathrm{V}_{\mathrm{c}}$ for selected field crops according to STN 830635 with simulated values of potential evapotranspiration $\mathrm{ET}_{0}$ according to $\mathrm{FAO}$ methodology for time horizons of years 2030, 2075 and 2100 for scenarios CCCMprep a GISSprep

As a next step, we calculated crop potential evapotranspiration according to FAO methodology. The results were compared wit consumptive water usage $\mathrm{V}_{\mathrm{c}}$ which is currently used in condition of Slovakia. The results are shown in Fig. 1 and Fig. 2. Analysis of simulated results for climate change scenarios showed increase of crops potential evapotranspiration for both climate change scenarios. The scenario $\mathrm{CCCM}_{\text {prep }}$ shows significantly higher values of ETo. The increase of ETo for particular crops is by 
9 up to $57 \%$ compared to consumptive water usage calculated according to currently valid Slovak Technical Standard STN 83 0635. The increase of ETo for GISS scenario is within the interval $3-51 \%$. Mean potential evapotranspiration value of vegetables will increase by $23 \%$ and by special plants will increase by $34 \%$. The highest increase of ETo value was found according to both scenarios by grape - $51 \%$ and the lowest by cauliflower $-4 \%$. In group of crops for oats ETo will decreas by 13 $\%$, pre oil-seed rape by $56 \%$. For another crops will increase variously e.g. for potatoes by $82 \%$ and sugar beet as for $89 \%$.

\section{Conclusions}

The obtained results of consumptive water usage calculations for time horizon of year 2100 showed substantial increasing of water demand for agroecological systems that is also manifested by instability of the productive systems. We may assume sufficient drought resilience potential for cultivation of fruit, vegetables and oil-bearing crops. The prognosis for cultivation of root crops and forage crops are unfavorable with high probability of irreversible damage of the systems. The possibilities of the problem solution may be based on breeding of new drought resilience species of crops, changes in crop patterns with preferences for crops of arid zones e.g. pulses, millet, sorghum and amaranthus. However an effective irrigation still belongs among the key element of agroecological systems stabilization in climate change condition.

\section{Acknowledgements}

This study was supported by Slovak Grant Agency - VEGA, No.1/0624/09, No. 1/0601/09, No.1/0110/08, No.1/0152/08 and by Slovak Research and Development Agency - APVV, No. 0271-07.

\section{References}

Allen, R. et al.: 1998. Crop evapotranspiration - Guidelines for computing crop water requirements. FAO Irrigation and drainage paper 56, Rome. 1998. ISBN 92-5-104219-5.

Hansen, S. - Jensen, H. E. - Nielsen, N. E. - Svendsen, H.: 1990. DAISY: Soil Plant Atmosphere System Model. NPO Report No. A 10, The National Agency for Environmental Protection, Copenhagen: 272.

Hardy, J. T.: 2003. Climate Change: Causes, Effects, And Solutions, Publisher: John Wiley \& Sons ISBN: 0470850191, Publishing Date: 2003-07-07

Lapin, M. - Melo, M.: 2002. Time Series scenarios of Ten Climate Characteristics for horizon 2001-2090 according to models CCCM2000 a GISS98. In: Proceedings of Abstracts of XIV. Czechoslovak Bioclimatological Conference: Bioclimate -Environment -Economy. Lednice: 4 (In Slovak)

Lapin, M.: 2004. Climate Change and Their Possible Impact on Hydrological Cycle - Scenarios of Changes till the year 2100 www.dmc.fmph.uniba.sk (In Slovak)

Parry, M. A. J. - Flexas, J. - Medrano, H.: 2005. Prospects for crop production under drought: research priorities and future directions. Ann Appl Biol 147. 211-226.

Šiška, B. - Takáč, J. - Igaz, D.: 2004. May we expect the yiekd distribution changes as an influence a climate change in Danubian Lowlands? In: Conference proceedings: Climat change - Weather Extremes. Organisms and Ecosystems. International Bioclimatological Workshop. Viničky 2. - 26. 8. 2004. CD ROM. (In Slovak)

Šiška, B. - Bízik, J. - Takáč, J. - Igaz, D.: 2002. Impact of Climate Change on Crop Production. Final Report of Research. SVP. š.p. Hydromeliorácie. Bratislava: 64 (In Slovak) 


\title{
CHANGES OF WATER RESOURCES AND SOILS AS COMPONENTS OF AGRO-ECOSYSTEM IN SLOVAKIA
}

\author{
Yvetta VELÍSKOVÁ
}

Institute of Hydrology, Slovak Academy of Sciences, Račianska 75, 83102 Bratislava, Slovakia, e-mail: veliskova@uh.savba.sk

\begin{abstract}
This contribution is dedicated especially to the water resources (WR) and soils in the agroecosystem of Slovakia. Quality of soils and WR are impacted with trend in agriculture, so for this reason the part of paper will deal with it. The most productive agricultural area of Slovakia is the Danube Lowland, notably the south part - the Rye Island (Žitný Ostrov), so it is very important to deal with water availability and soil characteristics in it. For this reason the part of contribution will be focused on this area. Evaluation period of particular indicators (e.g. $\mathrm{pH}, \mathrm{Cl}, \mathrm{NO}_{3}, \mathrm{COD}, \mathrm{GW}$ runoff, soil reaction, structure of agricultural land, trends of fertilizer consumption, etc.) is from 10 to 30 years, it depends on accessibility of monitoring data.
\end{abstract}

Keywords: water resources, soils, quality, quantity, fertiliser consumption

\section{Introduction}

Agro-ecosystem contains various components. The re-assessment of them and update of their changes is useful for specialists to understand and predict processes and also for better management or control of the area from different points of view. This contribution will be dedicated especially to the water resources (WR) and soils in the agro-ecosystem of Slovakia from quantitative and qualitative aspects. When the agroecosystem is analysed, it is appropriate also to deal with changes in using of an agricultural land. Besides, Rye Island (Žitný Ostrov) is one of the most productive agricultural areas of Slovakia, so it is very important to deal with quantity and quality of WR and soils at this region. Many specialists have studied this complex problem: Štekauerová and Nagy (2007), Pekárová et al., (2007), Jolánkai et al., (2008), Kulman, jr. and Kulman, sr. (2007), etc. In this paper there were used results of some of their contributions, results of field measurements, computer simulations and values from database of Slovak Hydro-Meteorological Institute (SHMI), Reports on water management in the Slovak Republic and State of the Environment Reports of the Slovak Republic published by Slovak Environmental Agency.

\section{Materials and methods}

Quality of surface water (SW), groundwater (GW) and soils was evaluated separately in this paper. Quantitative aspects of SW and GW in Slovakia territory were evaluated on the base of analysis of data published in Reports mentioned above and by Kulman, jr. Kulman, sr. (2007). Data for evaluation of soil properties and changes in using of an agricultural land come from Reports, field measurements and results of works by Kováčová, 2007, Burger and Čelková, 2009 and Štekauerová and Nagy, 2007. Results of field measurements and computer simulations were used for assessment of the Rye Island area. Data from field measurements in this area was supplemented with data from the database of SHMI. There were applied standard statistical methods for their preparing and processing. In relation to water quality assessment, it is necessary to note, that at present Slovakia is undergoing changes in SW assessment in consequence of the provisions of framework Directive on Water No. 2000/60/EC. In the past, the STN 75 
7221 "Water quality. Surface water quality classification" norm used as the primary reference in assessing water quality by Slovak Institute of Technical Normalisation, was invalidated since 1. 3. 2007. For this reason the quality assessment is performed by using some physical-chemical indicators.

\section{Results and discussion}

Total Slovak economy grew in last years faster than agricultural economy. Percentage of agriculture on gross domestic product dropped in 2007 to 2,5\%, as opposed to 4,7\% in 1996. One of the indicators of this state is value and structure of the agricultural land. In 1997, total area of agricultural land in Slovakia was 2444 thousand ha, whereas in 2007 it was only 2429 thousand ha. Course of fertiliser consumption during the years $1990-2007$ is shown in Fig. 1. The consumption of water in agricultural, especially for plant production and irrigation (possibly in agriculture and livestock production) represents Fig. 2.

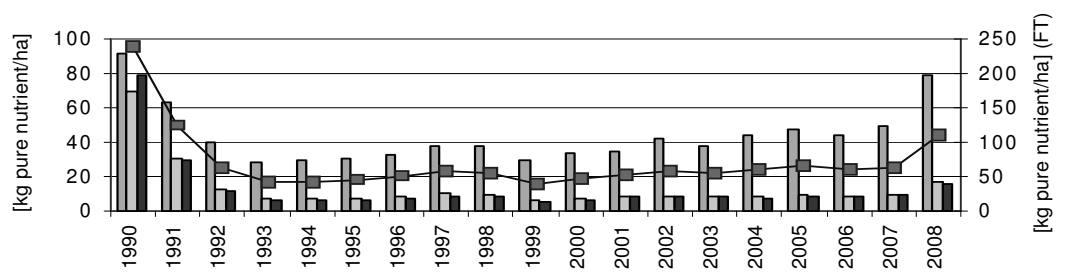

\begin{tabular}{ll|}
\hline Nitrogenous fertilisers & Phosphorous fertilisers \\
Potassium fertilisers & $\square$ Fertilisers total (FT) \\
\hline
\end{tabular}

Figure 1. Fertiliser consumption in Slovakia
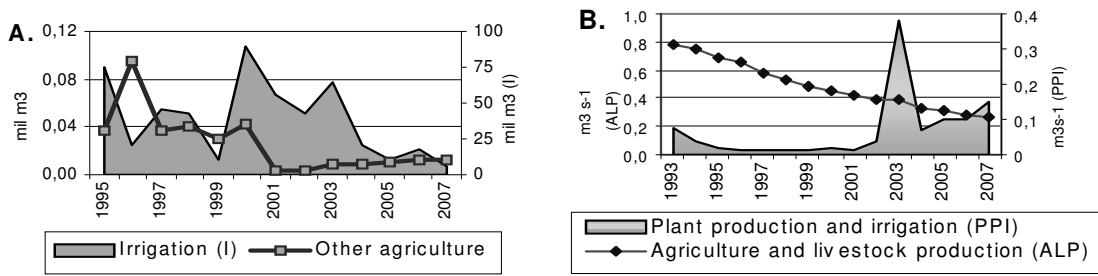

Figure 2. Trends in water use in agriculture in Slovakia (A. surface water; B. groundwater)

The usability of SW fund of Slovakia is limited. Due to its fluctuating characteristics the Slovak water potential is not able to cover all demands continuously, so it is necessary in some cases - to increase its volume by building reservoirs. Summary of the total hydrological balance of water resources during the period 1996-2007 is clearly documented in Fig.3. Considering GW, in 2007, there were approximately $77 \mathrm{~m}^{3} \mathrm{~s}^{-1}$ available GW resources. This value was obtained on the base of hydro-geological assessment and surveys in Slovakia. In the long-term evaluation, the increase of the efficient volume in comparison with 1990 makes 2,7\%. 


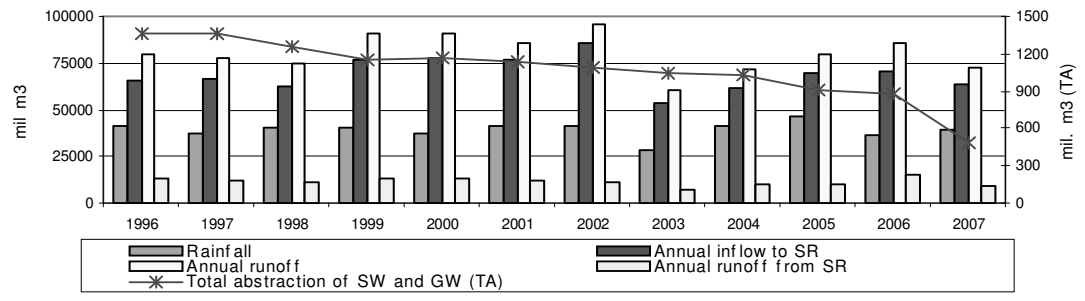

Figure 3. Total hydrological balance of water resources in Slovakia

As it was mentioned above, the principles of the quality water assessment changed in 2007. For this reason, there is difficult to perform an analysis of quality changes by a uniform principle and for whole territory of Slovakia. However, there was performed an assessment of some physical-chemical indicators in SW and GW at one of the most productive agricultural areas of Slovakia - the Rye Island area. Results are shown in Tab.1. Values in table serves only as a summary of observed data from this locality. In the case of the GW, indicators were evaluated at one locality in 3-7 test pits. In generally, the mean values of $\mathrm{Cl}^{-}$and $\mathrm{SO}_{4}{ }^{-}$noticeably decreased in one test pit.

Table 1. Physical-chemical indicators in surface water and groundwater at the Rye Island area

\begin{tabular}{|c|c|c|c|c|c|c|c|}
\hline & & Jelka $^{\text {GW }}$ & Mliečany $^{\mathrm{GW}}$ & Gabčíkovo $^{\mathrm{GW}}$ & $\check{C ̌ V ~ S e n e c ~}^{\text {SW }}$ & MD Jelka $^{\text {SW }}$ & D Gabčíkov $^{\text {sw }}$ \\
\hline \multirow{3}{*}{$\mathrm{pH}$} & mean & 7,47 & 7,5 & 7,5 & 7,73 & 7,64 & 8,12 \\
\hline & $\max$ & 8 & 7,9 & 8,15 & 8,50 & 9,00 & 8,84 \\
\hline & $\min$ & 6,4 & 6,75 & 5,65 & 0,30 & 6,50 & 7,50 \\
\hline \multirow{3}{*}{$\begin{array}{c}\mathrm{Cl}^{-} \\
{[\mathrm{mg} / \mathrm{l}]}\end{array}$} & mean & 37 & 22 & 17 & 33,9 & 28,42 & 17,09 \\
\hline & $\max$ & 83 & 84 & 120 & 113,9 & 91,20 & 31,00 \\
\hline & $\min$ & 9 & 10,5 & 1,33 & 11,2 & 10,00 & 7,10 \\
\hline \multirow{3}{*}{$\begin{array}{l}\mathrm{NO}_{3}^{-} \\
{[\mathrm{mg} / \mathrm{l}]}\end{array}$} & mean & 19,5 & 20 & 2,3 & 14,13 & 11,82 & 9,50 \\
\hline & $\max$ & 49 & 51 & 49,5 & 42,98 & 23,45 & 18,81 \\
\hline & $\min$ & 0,6 & 1,6 & 0,01 & 4,20 & 4,87 & 3,44 \\
\hline \multirow{3}{*}{$\begin{array}{l}\mathrm{SO}_{4}{ }^{2-} \\
{[\mathrm{mg} / \mathrm{l}]}\end{array}$} & mean & 112 & 75 & 59,5 & 61,95 & 53,03 & 29,35 \\
\hline & $\max$ & 165 & 327 & 369 & 252,50 & 214,80 & 43,50 \\
\hline & $\min$ & 38 & 35 & 4,8 & 11,30 & 19,10 & 17,50 \\
\hline \multirow{3}{*}{$\begin{array}{l}\mathrm{COD} \\
{[\mathrm{mg} / \mathrm{l}]}\end{array}$} & mean & 1,15 & 1 & 1,24 & 6,20 & 53,03 & 3,62 \\
\hline & $\max$ & 4,3 & 9,46 & 96 & 18,60 & 214,80 & 12,54 \\
\hline & $\min$ & 0,37 & 0,1 & 0,16 & 1,40 & 19,10 & 0,80 \\
\hline
\end{tabular}

Information on state and trend in some agricultural soil (AS) properties (by the Agrochemical soil testing) is shown in Fig. 4. Data show an increase in the proportion of AS with acid $(+6,2 \%)$ and weak acid soil reaction $(+8,8 \%)$. On the other hand, a reduction was seen in the proportion of AS with neutral $(+4,7 \%)$ and alkaline $(+10,3 \%)$ soil reaction. During the same period there was an increase in low supply of all three available nutrients - phosphorus, potassium and magnesium. It was by $14,6 \%$ in $\mathrm{P}$, by $10,7 \%$ in $\mathrm{K}$ and by $5,3 \%$ in $\mathrm{Mg}$. However, good supply of all three available 
nutrients was reduced during this period: $12,4 \%$ in $\mathrm{P}, 24,2 \%$ in $\mathrm{K}$ and $12 \%$ in $\mathrm{Mg}$. In terms of plant nutrition, it signals a negative tendency.
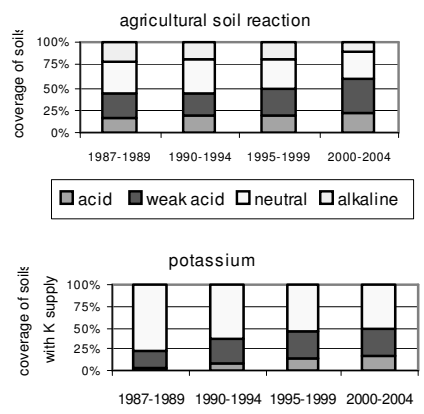

$\square$ low supply $\square$ middle supply $\square$ good supply
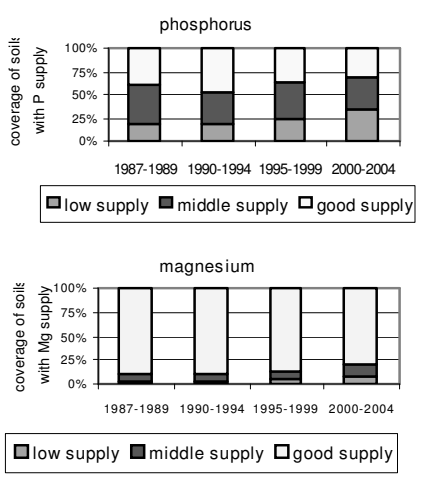

Figure 4. Trends in some agricultural soil properties

\section{Conclusions}

The aim of this paper was to give a view on changes of water resources and soil as ones of main components of agro-ecosystem in Slovakia. Part of it is focused to the Danube Lowland - the Rye Island area, which is the most productive agricultural area in Slovakia. The evaluation of these aspects is only partial, especially from point of view of their interaction. This is the role of the next time, because the processes that running among indicators and water resources in environment are complicated, data is not always accessible or compatible. However, knowledge in this contribution can be useful as a base for next research.

\section{Acknowledgements}

This work was supported by the contracts APVV-0271-07 and it is also the result of the project implementation ITMS 26240120014 Center of excellence for protection and use of landscape and biodiversity supported by the Research \& Development Operational Programme funded by the ERDF.

\section{References}

Annual reports about quality of surface water and groundwater, SHMI, 1991-2006.

Burger F. - Čelková A.: 2009. Salinization and contamination of subsurface environment. Institute of Hydrology SAS, Bratislava, ISBN 978-80-89139-17-0, CD (in Slovak)

Jolánkai M - Nyárai F.H. - Tarnawa A. - Klupács H. - Farkas I.: 2008. Plant and soil interrelations, Cereal Research Communications, 36: 1. 7-10.

Kováčová V.: 2007. Contamination in soil and its movement in dependence on groundwater level in the Danubian Lowland. Columbia University seminar proceedings. IH SAS Bratislava, Slovakia, 149-164.

Kulman, E. jr. - Kulman, E. sr.: 2007. Quantitative change of groundwater in space and time on Slovak territory. Podzemná voda, 13: 2. 135-145.

Pekárová P. - Onderka M. - Pekár J. - Rončák P. - Miklánek P.: 2009. Prediction of water quality in Danube River under extreme hydrological and temperature conditions. J. Hydrology and Hydromechanics, 57: 1. 3-15.

Reports on water management in the Slovak Republic, WRI Bratislava, 2006-2007 (in Slovak).

State of the Environment Report of the Slovak Republic, Slovak Environmental Agency, 1992-2008.

Štekauerová V. - Nagy V.: 2007. The influence of extreme meteorological phenomena on soil water regime of lowlands. Cereal Research Communications, 35: 1097-1100. 


\title{
CLIMATIC STRESS AND RESILIENCE RELATED TO WINTER WHEAT (TRITICUM AESTIVUM L.) YIELDS IN DIFFERENT CROPYEARS
}

\author{
Zsolt SZENTPÉTERY ${ }^{l}-$ András MÁTÉ ${ }^{2}-$ Ildikó FARKAS
}

${ }^{1}$ Szent István University, Gödöllő, e-mail: szentpetery.zsolt@gek.szie.hu

${ }^{2}$ Institute of Crop Production, Szent István University, Gödöllő

Abstract: Climate has a profound impact on crop production as it is an out-door activity. If climatic factors differ considerably from average level that means a higher level of stress that can disturbe phisiology of crops even as adaptive ones as winter wheat is. The reaction of wheat can be studied through the yield level deviation from average. Not only climate, that is give in a cropyear, determines yields but also agronomical factors that can be changed by grower, like variety used, level of plant nutrition, etc. In small plot experiments run at the Szent István University's Nagygombos experimental site in ten years series, treatments were the combinations of these agronomical factors. In this ten-year-period we had some cropyears with extrem climatic values. The impact of that climatic stress was modified by agronomic milieu regulated by our treatments. From the yields measured in each treatment in each crop year the ability of wheat for survive bad conditions can be assessed and also the possibility of grower to neutralise the impact of cropyear.

Keywords: Climate stress, winter wheat, yield, backing quality

\section{Introduction}

Cereals represent a most plausible source of human alimentation in the world. Utility, market and alimentation value of the crop is highly affected by climatic condition and within the annual weather performances. In wheat production the yield quantity and quality are determined by ecological (precipitation, temperature) and agro technical factors. The aim of wheat production is twofold: to provide quantity and quality. Milling and baking quality of wheat is mainly determined by the genetic basis, however it can be influenced by management techniques (Nagy et al., 2006). Quality and quantity success of the chosen species is influenced considerably by ecological conditions. Accordingly adaptability to the variable ecological, mainly weather conditions is a measure of value characteristics of the individual species (Balogh and Pepó, 2008). High temperature is one of the most important environmental factors during grain filling and may influence both the quantity and quality of the yield. High temperature after anthesis causes a reduction in grain filling (Veisz et al., 2008), more rapid apoptosis and the earlier attainment of harvest maturity.

\section{Materials and methods}

In long term field trials a wide range of high quality winter wheat varieties were examined under identical agronomic and monitored climatic conditions in the experimental years of 1999-2009 (OMSZ). From the varieties we have chosen the Alföld-90 variety, because this type were examinated in each year. The small plot trials were run at the Nagygombos experimental field of the SZIU Crop Production Institute. Soil type of the experimental field is chernozem (calciustoll). Experiment were conducted in spil-plot design with four replications. The size of each plot was $10 \mathrm{~m}^{2}$. Various agronomic treatments were applied to plots. Precipitation records have been evaluated in relations with yield quantity and quality. Yield, hl-weight, protein, 
farinographic value, wet gluten content and Hagberg falling number were correlated with precipitation and temperature.

\section{Results and discussion}

The 2000-2003 years were drought, in the 2004-2009 years the precipitation was average. We can see these tendencies in the figures of yields. The drought conditions increase the baking quality, however in the average years the quality figures were average as well (Table 1.).

Table 1. The quantity and quality figures of Alföld-90 variety in the examined period

\begin{tabular}{|c|c|c|c|c|c|c|}
\hline & yield [t/ha] & $\begin{array}{c}\text { wet gluten } \\
{[\%]}\end{array}$ & $\begin{array}{c}\text { baking } \\
\text { qualityvalue }\end{array}$ & $\begin{array}{c}\text { total protein } \\
\text { content [\%] }\end{array}$ & $\begin{array}{c}\text { hl-wight } \\
{[\mathrm{kg} / \mathrm{hl}]}\end{array}$ & $\begin{array}{c}\text { falling } \\
\text { number [s] }\end{array}$ \\
\hline \hline 2000 & 2,54 & 22,1 & 38,3 & 11,8 & 69,2 & 175 \\
\hline 2001 & 2,66 & 26,3 & 31,7 & 11,4 & 83,3 & 280 \\
\hline 2002 & 4,52 & 26,6 & 63,8 & 17,6 & 82,9 & 382 \\
\hline 2003 & 3,15 & 29 & 54,4 & 18,6 & 76,1 & 387 \\
\hline 2004 & 5,2 & 29,5 & 49,6 & 13,8 & 83,5 & 317 \\
\hline 2005 & 3,2 & 33,4 & 38,2 & 14,5 & 79,9 & 292 \\
\hline 2006 & 7,075 & 35,2 & 49,8 & 16,6 & 78,35 & 347 \\
\hline 2007 & 5,475 & 36,2 & 60 & 17,7 & 81,5 & 389 \\
\hline 2008 & 7,45 & 38 & 41,9 & 12,1 & 80,35 & 323 \\
\hline 2009 & 7,1 & 38,9 & 43,5 & 10,8 & 81,25 & 218 \\
\hline
\end{tabular}

The result of the yield figures and the weather-data has been compared to each other, climatic-indices $(\Sigma \Psi)$ were established (the sum of squares of the deviation from the mean precipitation and temperature figures of the very months, see Table 2 ).

Table 2. Climatic indices $(\Sigma \Psi)$ by month in each crop year

\begin{tabular}{|c|c|c|c|c|c|c|c|c|c|c|c|c|}
\hline & sept. & okt. & nov. & dec. & jan. & feb. & mar. & apr.. & may & jun. & jul. & average \\
\hline $\begin{array}{l}1999- \\
2000\end{array}$ & 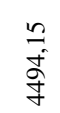 & $\begin{array}{l}\mathscr{n} \\
\dot{f} \\
f\end{array}$ & 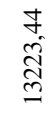 & $\begin{array}{l}F \\
\stackrel{\nabla}{r}\end{array}$ & $\begin{array}{l}\text { fo } \\
\text { to } \\
\frac{7}{7}\end{array}$ & กิ & $\begin{array}{l}\infty \\
\stackrel{n}{f}\end{array}$ & 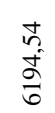 & $\frac{5}{6}$ & $\begin{array}{l}\infty \\
\infty \\
\text { } \\
\sigma\end{array}$ & $\begin{array}{l}\hat{b} \\
\text { ஸे } \\
\text { है }\end{array}$ & $\underset{G}{ت}$ \\
\hline $\begin{array}{l}2000- \\
2001\end{array}$ & $\begin{array}{l}\simeq \\
6 \\
0 \\
\infty\end{array}$ & $\begin{array}{l}\infty \\
\stackrel{2}{\hat{N}} \\
\stackrel{n}{n}\end{array}$ & $\begin{array}{l}\text { ले } \\
\text { ते }\end{array}$ & $\begin{array}{l}\hat{\sigma} \\
\tilde{\sigma}\end{array}$ & $\begin{array}{l}\text { N } \\
\stackrel{0}{0} \\
\stackrel{I}{I}\end{array}$ & $\begin{array}{l}\overline{0} \\
\infty \\
0\end{array}$ & 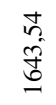 & $\begin{array}{l}\overparen{N} \\
\infty \\
\stackrel{0}{0}\end{array}$ & กิ & $\frac{n}{n}$ & 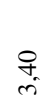 & $\stackrel{8}{8}$ \\
\hline $\begin{array}{l}2001- \\
2002\end{array}$ & 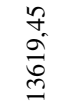 & $\begin{array}{l}n \\
\infty \\
n \\
\wp \\
n \\
n\end{array}$ & $\begin{array}{l}8 \\
\dot{8} \\
\infty\end{array}$ & $\begin{array}{l}g \\
\text { to } \\
\infty \\
\infty \\
\text { }\end{array}$ & $\begin{array}{l}\text { to } \\
\infty \\
\text { N } \\
\text { ñ. }\end{array}$ & $\begin{array}{l}n \\
2 \\
2 \\
\approx\end{array}$ & $\frac{n}{\frac{n}{a}}$ & ָ̊ & $\begin{array}{l}\stackrel{\infty}{+} \\
\stackrel{5}{\forall}\end{array}$ & $\begin{array}{l}\text { ஃั } \\
\text { ป }\end{array}$ & mे & $\stackrel{\overbrace{}}{0}$ \\
\hline $\begin{array}{l}2002- \\
2003\end{array}$ & $\frac{5}{6}$ & $\begin{array}{l}\text { J } \\
\text { 足 } \\
\text { I }\end{array}$ & 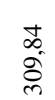 & $\frac{9}{0}$ & $\begin{array}{l}\stackrel{8}{2} \\
\text { ơ } \\
\text { I }\end{array}$ & 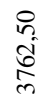 & 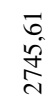 & 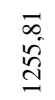 & $\begin{array}{l}\text { ㅇ. } \\
\text { g̊ }\end{array}$ & $\begin{array}{l}\stackrel{2}{2} \\
\infty \\
\frac{\infty}{ \pm}\end{array}$ & i & $\begin{array}{l}\text { C } \\
\infty \\
\text { in }\end{array}$ \\
\hline
\end{tabular}




\begin{tabular}{|c|c|c|c|c|c|c|c|c|c|c|c|c|}
\hline $\begin{array}{l}2003- \\
2004\end{array}$ & 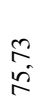 & 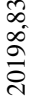 & $\begin{array}{l}0 \\
0 \\
0 \\
0\end{array}$ & 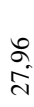 & $\begin{array}{l}\hat{\sigma} \\
\text { ñ }\end{array}$ & 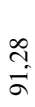 & 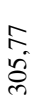 & $\begin{array}{l}m \\
\text { f́ } \\
\text { f }\end{array}$ & $\begin{array}{l}n \\
\text { nn } \\
\infty \\
\infty \\
\infty\end{array}$ & $\frac{8}{6}$ & $\begin{array}{l}\mathscr{1} \\
\infty \\
\infty \\
\infty \\
0\end{array}$ & à \\
\hline $\begin{array}{l}2004- \\
2005\end{array}$ & సิ & $\frac{ \pm}{i}$ & $\begin{array}{l}\hat{\imath} \\
\hat{\sigma}\end{array}$ & 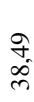 & $\begin{array}{l}\stackrel{0}{\infty} \\
\underset{\sim}{+}\end{array}$ & 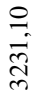 & $\frac{\hat{a}}{\bar{g}}$ & $\begin{array}{l}\text { r. } \\
8 \\
8 \\
0\end{array}$ & $\frac{1}{0}$ & $\begin{array}{l}\infty \\
\infty \\
0 \\
\text { లె }\end{array}$ & $\begin{array}{l}\text { के } \\
\text { से }\end{array}$ & $\stackrel{8}{\circ}$ \\
\hline $\begin{array}{l}2005- \\
2006\end{array}$ & $\stackrel{\nabla}{ \pm}$ & $\stackrel{n}{\underline{n}}$ & $\begin{array}{l}\hat{\alpha} \\
\text { }\end{array}$ & $\begin{array}{l}2 \\
\circ \\
\circ\end{array}$ & $\begin{array}{l}q \\
\dot{f}\end{array}$ & 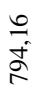 & $\begin{array}{l}\infty \\
\infty \\
\infty \\
+\end{array}$ & $\begin{array}{l}\stackrel{m}{a} \\
\stackrel{2}{2}\end{array}$ & 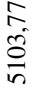 & $\begin{array}{l}\infty \\
\infty \\
\infty \\
\infty \\
\infty\end{array}$ & 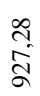 & $\begin{array}{l}\infty \\
\infty \\
\dot{m}\end{array}$ \\
\hline $\begin{array}{l}2006- \\
2007\end{array}$ & $\begin{array}{l}\text { Ja } \\
\stackrel{2}{2}\end{array}$ & ूे & 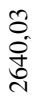 & $\begin{array}{l}\text { I } \\
\text { si } \\
\text { ơ }\end{array}$ & $\begin{array}{l}\text { a } \\
\text { d }\end{array}$ & 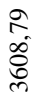 & $\begin{array}{l}\text { to } \\
\stackrel{+}{+}\end{array}$ & 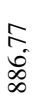 & $\begin{array}{l}\text { ते } \\
\text { ते }\end{array}$ & 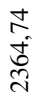 & 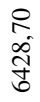 & \begin{tabular}{l} 
ते \\
\multirow{2}{\alpha}{} \\
$\alpha$
\end{tabular} \\
\hline $\begin{array}{l}2007- \\
2008\end{array}$ & $\stackrel{\infty}{\stackrel{\infty}{\stackrel{2}{\Xi}}}$ & 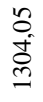 & $\underset{\vec{\Delta}}{\stackrel{\infty}{\Delta}}$ & $\frac{ \pm}{m}$ & $\begin{array}{c}\sigma \\
\text { ले }\end{array}$ & $\begin{array}{l}\text { ते } \\
\text { స̆ }\end{array}$ & $\begin{array}{l}\stackrel{R}{2} \\
\stackrel{2}{2}\end{array}$ & $\underset{r}{\stackrel{F}{r}}$ & $\overline{0}$ & $\begin{array}{l}\vec{n} \\
\infty \\
=\end{array}$ & 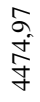 & जे \\
\hline $\begin{array}{l}2008- \\
2009\end{array}$ & $\stackrel{\widehat{\Omega}}{\Omega}$ & $\begin{array}{l}\vec{\Xi} \\
\stackrel{5}{\Xi} \\
=\end{array}$ & $\hat{n}$ & \begin{tabular}{l}
+ \\
\multirow{2}{*}{} \\
in \\
in
\end{tabular} & $\stackrel{n}{m}$ & हे & 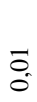 & $\begin{array}{l}\text { ठే } \\
\text { న̃ } \\
\text { సે }\end{array}$ & $\frac{?}{6}$ & 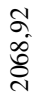 & $\begin{array}{l}\bar{\sigma} \\
\bar{\Omega}\end{array}$ & O̊ \\
\hline
\end{tabular}

The yield and wet gluten content was investigated from that point of view, that the low result years and the high result years were described in the same table and figure. 10 years of data were investigated: 7 high yields versus 3 low results, 6 and 4, 5 and 5, and so on. In the $3^{\text {rd }}$. and $4^{\text {th }}$. tables the best results were marked with red (dark) fields and the second best results were with yellow (light) fields. From these result were created the frequency index of cases, the red coloured fields represented two fold values and the yellows were representing one. These results are described by Figure 1.

Table 3. The yield and wet gluten level frequency indices

\begin{tabular}{|c|c|c|c|c|c|c|c|c|c|c|}
\hline & \multicolumn{2}{|c|}{$3-7$} & \multicolumn{2}{|c|}{$4-6$} & \multicolumn{2}{|c|}{$5-5$} & \multicolumn{2}{|c|}{$6-4$} & \multicolumn{2}{|c|}{$7-3$} \\
\hline & $\frac{\partial}{d}$ & 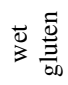 & $\frac{\partial}{d}$ & $\stackrel{\vec{D}}{\frac{D}{\Xi}}$ & $\frac{\pi}{\frac{\pi}{\lambda}}$ & 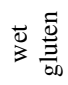 & $\frac{7}{\frac{0}{\lambda}}$ & $\stackrel{\overrightarrow{0}}{\frac{\Xi}{3}}$ & $\frac{\partial}{\frac{\pi}{\lambda}}$ & 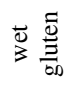 \\
\hline september & $\dot{m}_{0}^{+}$ & $\begin{array}{l}0 \\
0 \\
0\end{array}$ & in & $\stackrel{?}{0}$ & $\stackrel{2}{2}$ & $\frac{\infty}{0}$ & $\begin{array}{l}\stackrel{2}{2} \\
\text { o. }\end{array}$ & $\stackrel{\circ}{\circ}$ & 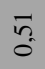 & $\stackrel{\overrightarrow{0}}{\circ}$ \\
\hline oktober & ô. & $\stackrel{?}{q}$ & $\underset{\text { I }}{\text { I }}$ & त̂. & $\stackrel{\text { I }}{0}$ & 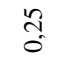 & $\stackrel{\infty}{\overbrace{0}^{\infty}}$ & $\stackrel{\infty}{0}$ & ț & $\ddot{0}$ \\
\hline november & $\overline{\tilde{o}}$ & $\begin{array}{l}\text { ते } \\
\text { o }\end{array}$ & $\overrightarrow{0}$ & $\vec{m}$ & $\stackrel{0}{\circ}$ & $=$ & $\hat{n}$ & $\stackrel{8}{\circ}$ & $\underset{0}{8}$ & $\begin{array}{l}\text { ñ } \\
\text { ô }\end{array}$ \\
\hline december & $\bar{n}$ & 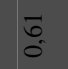 & in & $\vec{n}$ & $\stackrel{\infty}{+}$ & $\stackrel{\sim}{\circ}$ & $\begin{array}{c}\bar{\sigma} \\
\text { o }\end{array}$ & $\bar{m}$ & $\begin{array}{l}\text { तิ } \\
\text { ô }\end{array}$ & तิ \\
\hline january & $\bar{\sigma}$ & లి & हn & $\begin{array}{l}0 \\
0 \\
0\end{array}$ & గి. & $\underset{0}{0}$ & $\stackrel{m}{0}$ & $\overline{\tilde{o}}$ & $\begin{array}{l}\text { స్ } \\
0\end{array}$ & $\begin{array}{l}0 \\
0 \\
0\end{array}$ \\
\hline
\end{tabular}




\begin{tabular}{|c|c|c|c|c|c|c|c|c|c|c|}
\hline february & ?n & $\bar{n}$ & n. & ते & gु & $\stackrel{\infty}{0}$ & $\stackrel{\circ}{\circ}$ & ले & no & $\stackrel{\Delta}{0}$ \\
\hline march & $\frac{0}{0}$ & "n & है & ô. & $\bar{m}$ & : & $\begin{array}{c}\infty \\
\vdots \\
0\end{array}$ & $\stackrel{8}{0}$ & s. & $\stackrel{0}{0}$ \\
\hline april & तु & 8 & ते & o. & สุ & $\stackrel{2}{0}$ & तิ & तิ & त̂ & $\frac{7}{0}$ \\
\hline may & $\tilde{n}$ & $=$ & $\frac{0}{0}$ & $\overline{\sigma_{0}}$ & $\stackrel{\%}{0}$ & $\frac{\infty}{0}$ & ते है & $\bar{\pi}$ & สิ & $\stackrel{8}{\circ}$ \\
\hline june & $\bar{n}$ & to & $\frac{7}{0}$ & gi & $\overline{0}_{0}$ & $\stackrel{\infty}{0}$ & $\bar{m}$ & F & $\begin{array}{c}\infty \\
\text { a } \\
0\end{array}$ & $\stackrel{+}{\text { ¿ }}$ \\
\hline july & $\hat{\tilde{c}}$ & $\stackrel{8}{0}$ & สุ & $\stackrel{8}{0}$ & $\frac{m}{0}$ & $\overline{0}$ & ลิ & $\frac{m}{0}$ & है & 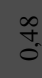 \\
\hline average & 5 & $\approx$ & F & $\overline{\tilde{c}}$ & $\stackrel{0}{0}$ & \begin{tabular}{l}
$\infty$ \\
\multirow{1}{0}{} \\
0
\end{tabular} & $\stackrel{\circ}{\circ}$ & के & $\vec{\pi}$ & $\stackrel{\infty}{0}$ \\
\hline $\begin{array}{l}\text { frequency- } \\
\text { index }\end{array}$ & $=$ & \pm & $\simeq$ & 0 & - & - & in & in & r & 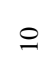 \\
\hline
\end{tabular}

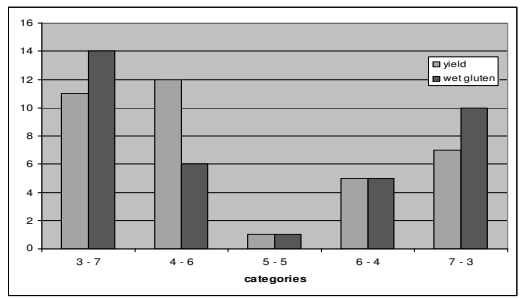

Figure 1. The frequecy-indices by categories

According to the figure the frequency indices were higher in the case of extreme weather conditions (3-7 and 7-3 graphs), in case of average weather conditions the quantity and the quality of the wheat yield could be considered stable.

\section{Acknowledgements}

The authors would like to express their thanks to NKTH and the Hungarian Scademy of Scirences for supporting this research.

\section{References}

Balogh, Á. - Pepó, P.: 2008. Crop year effects on the fertilizer responses of winter wheat genotypes. Cereal Res. Comm. 36: 731-734.

Nagy V. - Ján H.: 2006. Method to estimate the critical soil water content of limited availability for plants Biologia, 61. 19. 289-293 pp.

OMSZ - Hungarian Meteorological Service: http://met.hu/omsz.php

Veisz, O. - Bencze, Sz. - Balla, K. - Vida, Gy.: 2008. Change in water stress resistance of cereals due to atmospheric CO2 enrichment. Cereal Res. Comm. 36: 1095-1098. 


\title{
COMPARISON OF THE WATER USE EFFICIENCY OF MAIZE AND SORGHUM IN LYSIMETERS
}

\author{
József ZSEMBELI ${ }^{1}-$ Enikö BENE $^{2}$ \\ ${ }^{1}$ Research Institute of Karcag RIC CASE University of Debrecen, 5300 Karcag, Kisújszállási út 166. \\ zsembeli@dateki.hu \\ ${ }^{2}$ Faculty of Agriculture CASE University of Debrecen
}

\begin{abstract}
Maize and sorghum was studied in a lysimeter experiment in order to determine the water use efficiency of these two plants as farmers often have the dilemma if maize can be substituted by sorghum even with benefit (e.g. better water use efficiency) under the soil- and climatic conditions of the Great Hungarian Plain. This question is arisen even with a greater emphasis under irrigated conditions, especially as the safety of plant production can be ensured by irrigation only in droughty periods. Weighable lysimeters are very suitable tools for the determination of the water balance of the soil providing the possibility of the precise calculation of evapotranspiration, especially as the differences can be precisely quantified. One maize and one sorghum hybrids in three replications were applied as indicator crops for the comparison. Water balances for different time frames (seasonal, monthly, daily) were calculated involving the determination of each components of them. On the base of the different yield- and water balance parameters indexes characterising the water use efficiency of the crops were also calculated. It could be concluded that sorghum consumed 10 per cent more water under irrigated conditions and its daily duration of transpiration is longer. Nevertheless sorghum repaid for irrigation well as it needed 32\% less water to build up $1 \mathrm{~kg}$ plant biomass showing more favourable water use efficiency.
\end{abstract}

Keywords: irrigation, water use efficiency, maize, sorghum, lysimeter

\section{Introduction}

The control of the water regime of the soil will be of great importance in the food production worldwide (Láng et al., 1983; Várallyay, 1978). This will be one of the strategic question of the maintenance of soil fertility and the increase of crop yields. It can be predicted with no risk that water will become the main limiting factor of crop production in the future, especially taking the effects of the global climatic change into consideration. In Hungary farmers also want to accommodate to the changing conditions. There is long tradition of the efforts focus on saving water in agricultural use of water to ensure the safety of yield with as little amount of water as possible. On large areas of the Great Hungarian Plain irrigation can be used only conditionally (strictly taking its environmental impacts as secondary salinization, soil degradation, etc into consideration) due to the special ecological and soil conditions. Basically two approaches, water saving soil cultivation and the application of crops with higher water use efficiency) can be the solution of this problem, depending on the intensity of the production. Although maize can be grown successfully if its plant nutrition is rational (Sávári and Győri, 1998) on the better soils of the Great Hungarian Plain, nowadays sorghum has great a perspective as a potential substitution of maize as a fodder as well as an energy crop (Blaskó et al., 2008, Kovács et al., 2009). Nevertheless there are no sufficient, scientifically established and quantified data comparing the water use efficiency of maize and sorghum. 


\section{Materials and methods}

In 2009 an experiment was set at lysimeter station of the Karcag Research Institute in order to compare the water balance of sorghum and maize. One sorghum (Sucrosorgo) and one maize hybrid (PR37F73) were studied in three replications in the six weighable lysimeters of the institute. The sawing date was $17^{\text {th }}$ of April, 160:80:80 kg ha-1 substances of NPK fertilizers were applied at sawing time. During the examination period (June - September) the same amount of irrigation water was used for each lysimeter unit. The units were irrigated in smaller doses in order to avoid the high passive evaporation lost from the soil surface. All the lysimeters were irrigated with the same doses.

\section{Results and discussion}

Water balances for different time frames (seasonal, monthly, daily) were calculated involving the determination of each components of them. The water balances calculated for the whole examination period (June - September) are shown in Figure 1. As all the components of the water balance are indicated, it is well visible that the two indicator crops had different outputs even the water inputs (natural precipitation and irrigation) were exactly the same. Among the outputs, the difference in the amount of deep percolation water (drain water) has nothing to do with the plants and its very small quantity is not determining the difference experienced in the water regime of the crops. Much more dominant role has the evapotranspiration (ET) making the water balance of the two crops different. If we consider the 4 months of the investigated period, the average daily amount of ET is above $4 \mathrm{~mm}$. This value can be considered realistic taking the relevant meteorological conditions (warm summer) and the optimum-like water supply into account. As a summary it can be concluded that sorghum had approximately $10 \%$ higher water consumption than maize had even all the agrotechnical conditions were the same.

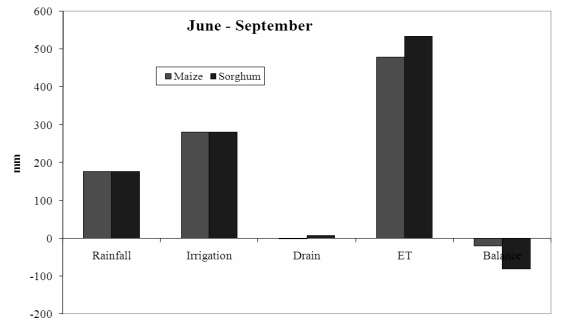

Figure 1. The water balances of maize and sorghum for the investigated period

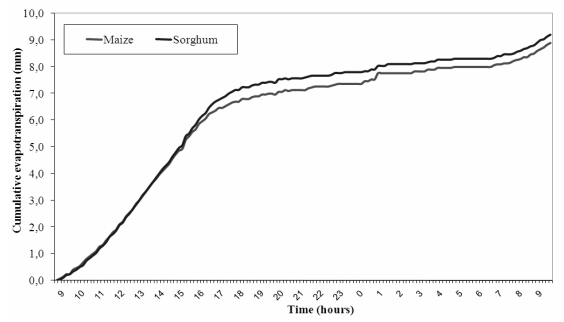

Figure 2. The daily cumulative evapotranspiration of maize and sorghum

Figure 2. shows the daily dynamics of ET of maize and sorghum. This time frame was used for the periods when no input water got into the lysimeters (periods between two water inputs). In these periods ET is the only output and it equals the water balance. As water balance was determined for every ten minutes, the dynamics of water loss after a 
higher input can be studied well with this time scale. In the figure it is visible that the dynamics of ET for both crops is similar until 4 p.m., but after that the ET value of sorghum remained high for longer, while maize transpirated less for a certain period. Later, from the evening hours, the difference disappeared again (parallel curves). It is obvious that difference arose in the ET during the late afternoon determined the difference of the water balance of the two crops. This tendency was experienced several times studying other periods too.

In order to assess the effect of irrigation on the water balance of maize and sorghum further, the yield data were also used. The harvest time was $25^{\text {th }}$ September. We measured the total biomass for both indicator crops, the corn and cob mass was determined for maize, while for sorghum, the sugar content was measured. Naturally the biomass yields of the two crops cannot be compared directly, but they were used as the base of further calculations for determining the water use efficiency. As we experienced different values of ET, the question arose if the water use efficiencies of the two crops are different as well. In other words, some economic calculations can answer the question whether the bigger biomass or yield can compensate the higher input originating from the higher water consumption. As the hydrological approach of this question some indexes characterising the water use efficiency of the crops were calculated. These indexes can be the bases of further economic calculations.

The ET of maize and sorghum in the function of the total water input of the investigated period is shown in Figure 3. This index shows whether the water balance was negative or positive, in other words if the water supply was sufficient (100\% or below) for the crop, or insufficient meaning that the crop decreased the moisture fund of the soil. In this experiment the water balances were negative, $10 \%$ of the water transpirated by maize originated from the soil moisture fund, while $24 \%$ in the case of sorghum. This result is in harmony with the literature data stating the soil drying capability of sorghum.

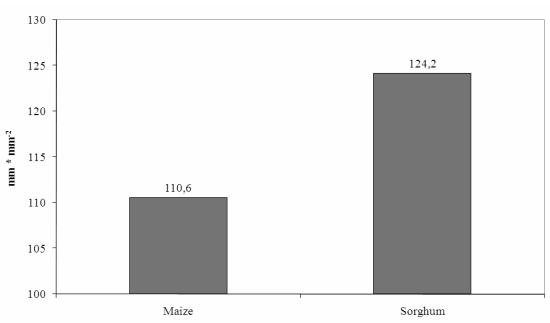

Figure 3. The ET of maize and sorghum in the function of the total water input for the investigated period

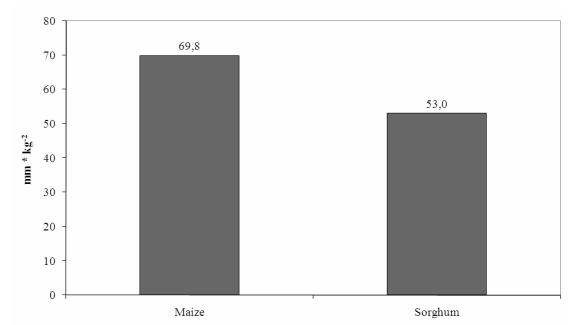

Figure 4. The ET of maize and sorghum in the function of the biomass production

The ET of maize and sorghum in the function of the total biomass production is shown in Figure 4. This index describes how much water was used to build up $1 \mathrm{~kg}$ of plant biomass during the investigated period. The results show a relatively higher water 
consumption of maize as it consumed less water in total, but approximately $32 \%$ more for producing $1 \mathrm{~kg}$ of biomass. This difference obviously originates from the higher biomass prodution of sorghum, but also means a better water use efficiency.

In Table 2. the water use efficiency indexes calculated for the main products of the two crops are shown. This index shows how much water was used to generate $1 \mathrm{~kg}$ of corn (with cob) in the case of maize and $1 \%$ of sugar in the case of sorghum. Naturally not the comparison of the two crops was our aim, but these values can be compared to other results gained under similar conditions.

Table 2. Water use efficiency indexes in the function of the yields

\begin{tabular}{|l|c|c|}
\hline \multicolumn{1}{|c|}{ Index } & Maizea & Sorghum \\
\hline \hline ET/corn+cob mass $(\mathrm{mm} / \mathrm{kg})$ & 187.3 & - \\
\hline ET/sugar content $(\mathrm{mm} / \%)$ & - & 29.9 \\
\hline
\end{tabular}

\section{Conclusions}

On the base of the different yield- and water balance parameters indexes characterising the water use efficiency of maize and sorghum were calculated. It could be concluded that sorghum consumed 10 per cent more water under irrigated conditions and its daily duration of transpiration is longer. Nevertheless sorghum repaid for irrigation well as it needed $32 \%$ less water to build up $1 \mathrm{~kg}$ plant biomass showing more favourable water use efficiency. Weighable lysimeters are very suitable tools for the determination of the water balance of the soil providing the possibility of the precise calculation of evapotranspiration, especially as the differences can be precisely quantified.

\section{References}

Blaskó L. - Balogh I. - Ábrahám É. B.: 2008. Possibilities of sweet sorghum production for ethanol ont he Great Hungarian Plain. Suppl. Cereal Research Communications, 36, 1251-1254.

Kovács G. - Mikó P. - Nagy L. - Balla I. - Gyuricza Cs.: 2009. Talajművelési eljárások hatása a cukorcirok (Sorghum bicolor L.) beltartalmi és fenológiai paramétereire. V. Növénytermesztési Tudományos Nap, Keszthely, 121-125. Akadémiai Kiadó Budapest.

Láng, I. - Csete, L. - Harnos, Zs.: 1983. A magyar mezőgazdaság agroökológiai potenciálja az ezredfordulón. Mezőgazdasági Kiadó, Budapest.

Sárvári M - Győri Z. : 1981. A monokultúrában és vetésváltásban termesztett kukorica termésátlagának és minőségének változása különböző tápanyagellátás esetén. Növénytermelés, vol. 31. 2. pp: 177-185.

Várallyay GY.: 1978. A talajfizika helyzete és jövőbeli feladatai. Agrokémia és Talajtan. 27. sz. 203 - 218.

Zsembeli J. - Kovács Gy. - Murányi A. - Tanaka, T.: 2009. Water use efficiency of sorghum and maize treated with PENTAKEEP-V. 13. Gumpensteiner Lysimeteragung, Austria, 59-61. ISBN-13:978-3902559-31-9, ISSN: 1818-7722. 


\title{
EFFECT OF FOLIAR FERTILIZERS ON CHLOROPHYLL CONTENT INDEX AND YIELD OF POTATO CROP GROWN UNDER WATER STRESS CONDITIONS
}

\author{
Tea HORVAT ${ }^{l}$ - Milan POLJAK ${ }^{l}$ - Boris LAZAREVIC ${ }^{l}$ - Zlatko SVEČNJAK ${ }^{2}$ - \\ Tomislav KARAŽIJA ${ }^{\text {I }}$ \\ ${ }^{1}$ Department of Plant Nutrition, Faculty of Agriculture, University of Zagreb, Svetošimunska 25, HR-10000 \\ Zagreb, Croatia, e-mail: thorvat@agr.hr \\ 2 Department of Field Crop Production, Grassland and Forages, Faculty of Agriculture, University of Zagreb
}

Abstract: The aim of this study was to determine the effect of three foliar fertilizers (Epso Salt, Megagreen and Drin) and control treatment (with no foliar fertilizer) on the chlorophyll content index, tuber size and yield of potato crop grown under water stress conditions. The experiment was conducted during three growing seasons (2005, 2006 and 2007) in the greenhouse using variety 'Courage' and arranged in a split-plot design with three replications. Foliar fertilization was carried out five times during vegetation in the period from the start of tuber formation to the stage of full tuberization. Water stress was induced at the full tuberization growth stage. There was no significant difference in chlorophyll content index in potato leaf influenced by foliar fertilizers between water stress conditions and optimum water supply. However, tuber yield was significantly reduced by an average of $15 \%$ under water stress conditions. In addition, water stress resulted in a significantly higher number of $0-25 \mathrm{~mm}$ size tubers, but lower number of $50-75 \mathrm{~mm}$ size tubers. Foliar application of Epso Salt brought about similar tuber yields under conditions of water stress and optimum water supply. In contrast, Megagreen, Drin and control treatment achieved significantly higher tuber yield under optimum water supply when compared to water stress conditions.

Keywords: potato, foliar fertilizers, water stress, chlorophyll content index, tuber yield

\section{Introduction}

Water stress is an important factor which induces significant alterations in plant physiology and biochemistry (El-Tayeb, 2006). It causes inhibition of growth which is reflected in a restriction of chlorophyll content and photosynthesis, dry matter formation and yield (Poljak et al., 2005; Hnilička et al., 2007). The potato (Solanum tuberosum L.) is well known as one of the most sensitive crops to water stress. Water stress during mid and late bulking periods reduces yield while increases the percentage of undersized tubers and causes tubers brown spots (Horvat et al., 2008). Soil fertilization is not always sufficient to meet the needs of crops, especially in water stress conditions, because the root is not able to absorb nutrients in adequate quantities from the upper layer of dry soil. Furthemore, in water stress conditions transport of certain nutrients ( $\mathrm{Ca}, \mathrm{Mg}, \mathrm{B}, \mathrm{Mn}$ ) that are transported through the plant by xylem is limited. Apart from soil fertilization, fertilizers can be applied foliar through leaves and stems. On the market there are different foliar fertilizers, which are often mixtures of micronutrients and secondary nutrients. Their application is recommended to increase the yield and quality of crops. However, there are very few scientific results based on their effectiveness on the plants metabolism.

The objective of this study was to determine the effect of foliar fertilizers on the chlorophyll content index, tuber size and yield of potato crop grown under water stress conditions. 


\section{Materials and methods}

The experiment was conducted during three growing seasons $(2005,2006$ and 2007) in the greenhouse of the Faculty of Agriculture, University of Zagreb in partly controlled conditions. Potato tubers of variety 'Courage' were planted in $25 \mathrm{~L}$ pots filled with a mixture of soil and perlite at a ratio of $3: 1$. The basic fertilization, calculated per pot, was carried out with $700 \mathrm{~kg} \mathrm{ha}^{-1} \mathrm{NPK}$ 7:20:30 and $250 \mathrm{~kg} \mathrm{ha}^{-1}$ KAN at pre-planting. The experiment consisted of three foliar fertilizers (Epso Salt $(\mathrm{Mg}, \mathrm{S}, \mathrm{B}, \mathrm{Mn})$, Drin (alpha amino acid), Megagreen (Ca) and control treatment (with no foliar fertilizer) and was arranged in a randomized split-plot design with three replications. Foliar fertilization was carried out five times during vegetation $(50,60,70,80$ and 90 days after planting) in the period from the start of tuber formation to the stage of full tuberization. Foliar fertilizers were applied as instructed by manufacturers (Epso Salt at a dose of $25 \mathrm{~kg} \mathrm{ha}^{-1}$, Drin $0,51 \mathrm{ha}^{-1}$ and Megagreen at a dose of $2 \mathrm{~kg} \mathrm{ha}^{-1}$ ) with the water consumption of $3001 \mathrm{ha}^{-1}$ calculated per pot. Drip irrigation was used. Water deficit stress was induced at the full tuberization growth stage ( 90 days after planting) by interrupting the irrigation. Chlorophyll content index in potato leaves was measured by portable CCM 200 apparatus (ADC, Bio Scientific Ltd. UK) on the second and sixth day after exposure of plants to water stress. After 20-day exposure of plants to water stress, fresh tuber yield and the number of tubers by size were calculated. Data were analyzed with analysis of variance. Mean separation was obtained using a protected LSD test at the 0,05 probability level when significant F-tests $(\mathrm{P} \leq 0.05)$ were observed.

\section{Results and discussion}

Chlorophyll content index significantly differed depending on the water stress conditions and optimum water supply conditions in individual growing seasons (Figure 1). In 2005 and 2006, a significant difference in chlorophyll content index in water stress and optimum water supply conditions was not found. In contrast, chlorophyll content index in water stress conditions in 2007 was 18,7 and was significantly lower by $40 \%$ compared to optimum water supply conditions $(31,0)$. Reduction of chlorophyll content in water stress conditions was reported by Kiani et al. (2008). There was no significant difference in chlorophyll content index in potato leaf influenced by foliar fertilizers between water stress conditions and optimum water supply in both growing seasons.

The analysis of variance showed that water stress significantly influenced the potato tuber yield and number of 0-25 $\mathrm{mm}$ and $50-75 \mathrm{~mm}$ size tubers (Table 1). Potato tuber yield was significantly reduced in water stress conditions by an average of $15 \%$ and amounted $370,0 \mathrm{~g}$ per plant compared with $433,5 \mathrm{~g}$ per plant under optimum water supply conditions. The negative impact of water stress during and at the end of tuber bulking on potato yield and quality was also found by Pereira and Shock (2006). The authors reported the reduction in yield and specific gravity and increase in reducing sugar in potato tuber due to water stress. 
$\square$ Stress $\square$ Non stress

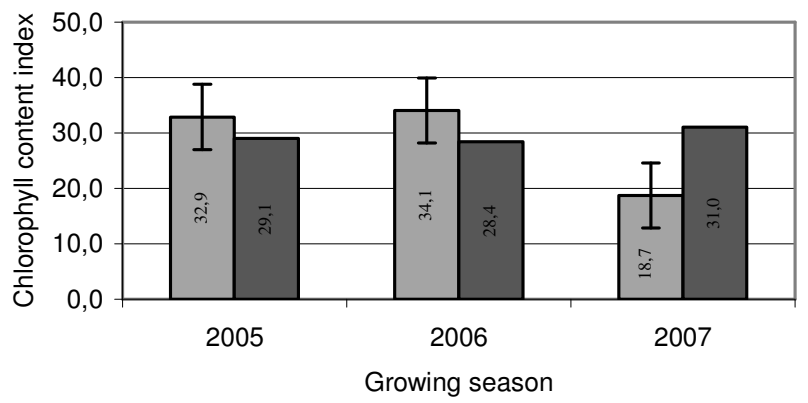

Figure 1. The average chlorophyll content index in stress and non stress conditions in growing seasons 2005, 2006 and 2007. LSD 0,05 =5,9; bars apply for comparing stress and non stress conditions within the same growing season.

Foliar treatments significantly differed in tuber yield produced under water stress and optimum water supply conditions (Table 1).

Table 1. Combined analysis of variance for potato yield and number of tubers by size.

\begin{tabular}{|c|c|c|c|c|}
\hline \multirow{2}{*}{ Source of variation } & \multirow{2}{*}{$\begin{array}{c}\text { Potato yield } \\
\text { (g per plant) }\end{array}$} & \multicolumn{3}{|c|}{ Number of tubers by size } \\
& $*$ & $* *$ & NS & $*$ \\
\hline \hline Growing season (GS) & $*$ & NS & NS & $*$ \\
\hline Treatment (T) & NS & NS & NS & NS \\
\hline GS $\times$ T & $* *$ & $*$ & NS & $*$ \\
\hline Stress (S) & $*$ & NS & NS & NS \\
\hline GS $\times$ S & $*$ & NS & NS & NS \\
\hline T $\times S$ & &
\end{tabular}

NS Not significant; * Significant at $\mathrm{P} \leq 0.05 ; * *$ Significant at $\mathrm{P} \leq 0.01$

Foliar application of Epso Salt brought about similar tuber yields under conditions of water stress and optimum water supply (Figure 2). In contrast, plants subjected to control, Megagreen and Drin had a significantly higher tuber yield under optimum water supply when compared to water stress conditions. Takacs-Hajos et al. (2007) indicated a positive impact of foliar fertilizer Epso Salt on the yield and quality of sugar beet. In water stress conditions Megagreen treatment achieved a higher yield (418,3 g per plant). The smallest yield in stress conditions was obtained under the influence of Drin treatment. In water stress conditions, a significantly higher number of 0-25 mm size tubers, but lower number of $50-75 \mathrm{~mm}$ size tubers was determined. The likely reason is that in water deficit conditions the stoma closure decreased the intensity of photosynthesis, prevented the translocation of assimilates into the tuber and further thickening. A reduced number of larger tubers in water stress conditions was reported by Walworth and Carling (2002). The absence of interaction between treatments and stress indicate that treatments responded similarly in the number of tubers by size in water stress and optimum water supply conditions (Table 1).

217 DOI: 10.1556/Novenyterm.59.2010.Suppl.3 
$\square$ Water stress $\square$ Non-w ater stress

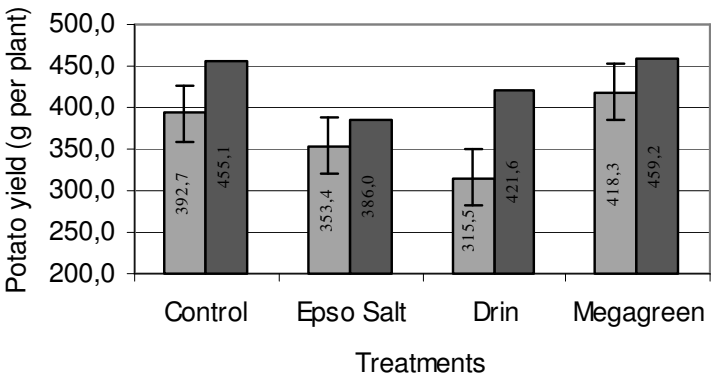

Figure 2. The average yield of potato tubers following application of foliar treatments compared with control in stress and non stress conditions. LSD $0,05=33,53 \mathrm{~g}$ per plant; bars apply for comparing treatment in stress and non stress conditions.

\section{Conclusions}

A significantly lower average tuber yield was attained in water stress conditions. In addition, water stress resulted in a significantly higher number of $0-25 \mathrm{~mm}$ size tubers, but lower number of 50-75 mm size tubers. Our findings have shown a positive impact of foliar fertilizer Epso Salt on potato tuber yield in water stress conditions. There was no significant difference in chlorophyll content index in potato leaf influenced by foliar fertilizers between water stress conditions and optimum water supply.

\section{References}

El-Tayeb, M.A.: 2006. Differential response of two Vicia faba cultivars to drought: Growth, pigments, lipid peroxidation, organic solutes, catalase and peroxidase activity. Acta Agronomica Hungarica, 54: 1. 25-37.

Hnilička, F. - Hniličková, H. - Martinková, J. - Bláha, L.: 2007. The influence of drought and the application of 24 -epibrassinolide on the formation of dry matter and yield in wheat. Cereal Research Communications, 35: 2. 457-460.

Horvat, T. - Poljak, M. - Majić, A. - Svečnjak, Z. - Jurkić, V.: 2008. Effects of foliar fertilization and water stress on yield and physiological characteristics of potato. Cereal Research Communications, 36: 3 . 16591662.

Kiani, S:P. - Maury, P. - Sarrafi A. - Grieu, P.: 2008. QTL analysis of chlorophyll fluorescence parameters in sunflower (Helianthus annuus L.) under well-watered and water-stressed conditions. Plant Sciences, 175: $565-573$.

Pereira, A.B. - Shock, C. C.: 2006. Development of irrigation best management practices for potato from a research perspective in the United States. Sakia.org e-publish, 1: 1. 1-20.

Poljak, M. - Ćosić, T. - Herak-Ćustić, M. - Horvat, T. - Buturac, I.: 2005. Potato nitrogen fertilization efficiency. Proceedings of the XL Croatian Symposium on Agriculture with International Participation. Faculty of Agriculture, University of J. J. Strossmayer, Osijek, 369-370.

Takacs-Hajos, M. - Szabo, L. - Racz, I. - Mathe, A. - Szőke, E.: 2007. The effect of Mg-leaf fertilization on quality parameters of some horticultural species. Cereal Research Communications, 35: 2. 1181-1184.

Walworth, J.L. - Carling, D.E.: 2002. Tuber initiation and development in irrigated and non-irrigated potatoes. American Journal of Potato Research, 79: 6. 387-395. 


\title{
EFFECTS OF DROUGHT ON GRAIN QUALITY PARAMETERS IN WINTER WHEAT
}

\author{
Pavlína HRSTKOVÁ ${ }^{l}-$ Karel VEJRAŽKA ${ }^{2}$ \\ ${ }^{1}$ Dept. of Crop Science, Plant Breeding and Plant Medicine, Faculty of Agronomy, Mendel University, \\ Zemědělská 1, CZ 61300 Brno, hrstkova@mendelu.cz \\ ${ }^{2}$ Agricultural Research Ltd., Zahradní 1, CZ 66441 Troubsko
}

\begin{abstract}
The effects of water availability on the winter wheat quality parameters were studied in the field experiments in the Czech Republic in 2006/07; 2007/08 and 2008/09 seasons. The plot trials were performed simultaneously on a clayey soil with good water retention and on a drought prone sandy soil. The reduced water availability on sandy site was confirmed by a continuous soil moisture measurement in all years. Commercially grown wheat varieties (16) with a different bread making quality according to the Czech standards were chosen for the experiment and the grain samples were evaluated for protein content, Hagberg falling number, Zeleny sedimentation volume, gluten content and gluten index. Grain hardness was assessed using the Single Kernel Characterization System 4100 (SKCS). The results showed that drought significantly increased protein content, Zeleny volume and gluten content. The impact on HFN and grain hardness was small and the gluten index was much higher in grain from more humid conditions.
\end{abstract}

Keywords: winter wheat, drought, quality parameters, grain hardness.

\section{Introduction}

Winter wheat breeding programs are commonly aimed also at better performance of new varieties under water deficient conditions (Cseuz et al., 2009). Limited water availability has got a basic impact not only on the grain yield but also on grain quality. In general the grain from plants subjected to drought and high temperatures is characteristic by high protein content, low starch content and changes in protein fractions ratio (Balla et al., 2009). As the protein content is a purely quantitative trait, the gluten quality has to be assessed using further parameters as sedimentation test, wet gluten content or the strength of gluten (gluten index). In spite of high protein content the grain affected by drought is considered as of lower quality (Weightman et al., 2008). Crop/variety resilience is widely studied for quantitative characters with low heritability, i.e. yield (Falco and Chavas, 2008) or starch content. In wheat these traits are affected by the length of grain filling period that can be significantly shortened by the lack of water. Kernel characteristics, as hardness, are related to important milling properties, such as conditioning, flour particle size, starch damage, water absorption and milling yield (Lyford et al., 2005). The relative hardness or softness of a grain can be defined as a measure of the resistance to deformation. The single-kernel characterization system (SKCS) evaluates wheat kernel texture characteristics by measuring the weight, electrical current, and force needed to crush the kernels (Anderssen and Haraszi, 2009). Hardness values for hard wheats are around 75 and for soft wheats around 30 (Gaines et al., 1996; Turnbull and Rahman, 2002). Although grain hardness is strongly genetically determined trait, it can be influenced by the environment, particularly by conditions during grain filling. 


\section{Materials and methods}

The effects of limited water availability on the winter wheat quality parameters were studied in the field experiments in the Czech Republic in 2006/07; 2007/08 and 2008/09 growing seasons. Sixteen commercially grown wheat varieties (Triticum aestivum L) with a different bread making quality according to the Czech standards were chosen for the experiment. The standard plot trials were performed simultaneously on two sites with different soil conditions at Žabčice location (South Moravia region $49^{\circ} 01^{\prime} \mathrm{N}$; $16^{\circ} 37^{\prime} \mathrm{E} ; 179$ m.s.1.). The A site was characterized by a clayey soil with good water retention (gleyic fluvisol, $51 \%$ of clayey particles), the B site was on a drought prone sandy soil of chernozem type formed on a gravel terrace $(20-28 \%$ of clayey particles). The long term (1961-1990) average annual temperature in Žabčice is $9.2^{\circ} \mathrm{C}$ and the average sum of annual precipitation is $480 \mathrm{~mm}$. An uneven rainfall distribution and relatively high temperatures result in common occurrences of drought periods mainly from April to September. The reduced water availability on sandy site was confirmed by a continuous soil moisture measurement in all years (data not given).

Table 1. Grain characteristics determined for 16 varieties at two sites for three seasons

\begin{tabular}{|c|c|c|c|c|c|c|c|c|c|c|c|c|c|c|}
\hline \multirow[t]{2}{*}{ Trial } & \multirow[t]{2}{*}{ Year } & \multirow[t]{2}{*}{$\mathrm{N}$} & \multicolumn{4}{|c|}{ Protein content DM (\%) } & \multicolumn{4}{|c|}{ Zeleny test volume (ml) } & \multicolumn{4}{|c|}{ Hagberg falling number (s) } \\
\hline & & & Mean & SD & Min. & Max. & Mean & SD & Min. & Max. & Mean & SD & Min. & Max. \\
\hline \multirow{4}{*}{$\begin{array}{c}\text { Site } \\
\text { A }\end{array}$} & 2007 & 16 & 12.7 & 1.6 & 9.9 & 16.8 & 30.9 & 8.6 & 20.0 & 47.0 & 341 & 38 & 262 & 401 \\
\hline & 2008 & 16 & 14.0 & 0.9 & 12.8 & 15.5 & 50.2 & 11.1 & 27.0 & 65.0 & 400 & 30 & 341 & 453 \\
\hline & 2009 & 16 & 14.2 & 0.8 & 12.9 & 15.6 & 45.7 & 11.1 & 26.0 & 66.0 & 349 & 40 & 268 & 397 \\
\hline & Mean & 48 & 13.6 & 1.3 & & & 42.3 & 13.1 & & & 363 & 44 & & \\
\hline \multirow{4}{*}{$\begin{array}{c}\text { Site } \\
\text { B }\end{array}$} & 2007 & 16 & 17.4 & 1.0 & 16.0 & 19.2 & 46.9 & 9.1 & 32.0 & 64.0 & 373 & 37 & 286 & 442 \\
\hline & 2008 & 16 & 20.5 & 1.0 & 18.8 & 22.4 & 66.6 & 5.2 & 56.0 & 73.0 & 417 & 48 & 320 & 493 \\
\hline & 2009 & 16 & \begin{tabular}{|l|}
19.2 \\
\end{tabular} & 1.4 & 17.0 & 21.5 & 69.1 & 4.9 & 60.0 & 75.0 & 315 & 53 & 237 & 419 \\
\hline & Mean & 48 & 19.0 & 1.7 & & & 60.9 & 12.0 & & & 368 & 62 & & \\
\hline
\end{tabular}

\begin{tabular}{|c|c|c|c|c|c|c|c|c|c|c|c|c|c|c|}
\hline \multirow[t]{2}{*}{ Trial } & \multirow[t]{2}{*}{ Year } & \multirow[t]{2}{*}{$\mathrm{N}$} & \multicolumn{4}{|c|}{ Wet gluten content $(\%)$} & \multicolumn{4}{|c|}{ Gluten index } & \multicolumn{4}{|c|}{ SKCS } \\
\hline & & & Mean & SD & Min. & Max. & Mean & $\mathrm{SD}$ & Min. & Max. & Mean & SD & Min. & Max. \\
\hline \multirow{4}{*}{$\begin{array}{c}\text { Site } \\
\text { A }\end{array}$} & 2007 & 16 & \begin{tabular}{|l|}
28.9 \\
\end{tabular} & 4.4 & \begin{tabular}{|l|l}
19.9 \\
\end{tabular} & 34.6 & \begin{tabular}{|l}
89.9 \\
\end{tabular} & 12.4 & 64.0 & 100.0 & 58.0 & 16.7 & 21.7 & 83.3 \\
\hline & 2008 & 16 & \begin{tabular}{|l|}
36.1 \\
\end{tabular} & 3.8 & 29.3 & 43.1 & \begin{tabular}{|l|}
93.3 \\
\end{tabular} & 6.9 & 79.4 & 100.0 & 50.8 & 18.4 & 7.1 & 68.1 \\
\hline & 2009 & 16 & 36.4 & 2.5 & 32.7 & 40.8 & 73.2 & 16.3 & 37.0 & 93.3 & 54.1 & 21.0 & 6.9 & 75.0 \\
\hline & Mean & 48 & 33.8 & 5.0 & & & 85.5 & 15.1 & & & 54.3 & 18.6 & & \\
\hline \multirow{4}{*}{$\begin{array}{c}\text { Site } \\
\text { B }\end{array}$} & 2007 & 16 & 42.4 & 3.3 & 37.7 & 48.8 & \begin{tabular}{|l|}
67.0 \\
\end{tabular} & 17.8 & 36.0 & 96.3 & \begin{tabular}{|l|}
61.4 \\
\end{tabular} & 17.5 & 17.9 & 76.3 \\
\hline & 2008 & 16 & 59.7 & 5.9 & 52.5 & 74.0 & \begin{tabular}{|l}
63.6 \\
\end{tabular} & 7.8 & 45.4 & 75.6 & 53.6 & 18.8 & 9.8 & 78.5 \\
\hline & 2009 & 16 & \begin{tabular}{|l|}
53.6 \\
\end{tabular} & 6.5 & 45.1 & 65.6 & 55.1 & 10.4 & 41.7 & 83.5 & 57.1 & 16.1 & 19.1 & 78.2 \\
\hline & Mean & 48 & 51.9 & 9.0 & & & \begin{tabular}{|l|l}
61.9 \\
\end{tabular} & 13.4 & & & \begin{tabular}{|l|l} 
\\
57.3
\end{tabular} & 17.4 & & \\
\hline
\end{tabular}

SD - stardard deviation; min. - minimum value; max. - maximum value 
The gain yield was significantly lower at the B site. After the harvest the grain samples were evaluated for protein content on a dry weight basis and grain moisture (FOSS 6500), Hagberg falling number (HFN) and Zeleny sedimentation volume according to ISO standards, wet gluten content and gluten index (Glutomatic, Perten). Grain hardness was assessed using the Single Kernel Characterization System (SKCS 4100, Perten).

\section{Results and discussion}

The average values for all measured grain characteristics are given in Table 1. The grain quality from A site was basically comparable with the quality values from similar trials, at the yield level of 9-10 t.ha ${ }^{-1}$ some lower quality varieties did not meet the standards required for bread making wheat, particularly in the harvest year 2007. The grain from B site was typical of dry areas, with very high protein content (19\%), Zeleny test volume $(60.9 \mathrm{ml})$, and wet gluten content $(51.9 \%)$ and lower gluten index (61.9) in all three years. For HFN and grain hardness no significant differences were found between sites. While HFN depends on the amount of precipitation before harvest, grain hardness is a trait strongly determined by a genotype, particularly by the specific mutation of puroindoline genes (Nadolska-Orczyk et al., 2009). Only two from 16 varieties had SKCS units below 30 and belonged to the soft class (Arida 14; Venistar 16) and two reached values over 70 (Hedvika 72; Mulan 73).

Table 2. Correlation coefficients for grain characteristics

\begin{tabular}{|l|r|r|r|r|r|}
\hline Site A & Zeleny vol. & \multicolumn{1}{c|}{ HFN } & Wet gluten & Gluten ind. & SKCS \\
\hline \hline Protein cont. & $0,70^{*}$ & 0,26 & $0,78^{*}$ & $-0,01$ & $-0,04$ \\
\hline SKCS & 0,27 & $0,34 *$ & 0,01 & $-0,13$ & \\
\hline Gluten ind. & 0,21 & 0,24 & $-0,27$ & & \\
\hline Wet gluten & $0,60 *$ & $0,32 *$ & & & \\
\hline HFN & $0,55^{*}$ & & & & \\
\hline
\end{tabular}

\begin{tabular}{|l|r|r|r|r|r|}
\hline Site B & Zeleny vol. & \multicolumn{1}{c|}{ HFN } & Wet gluten & Gluten ind. & SKCS \\
\hline \hline Protein cont. & $0,65^{*}$ & 0,25 & $0,82^{*}$ & $-0,03$ & $-0,16$ \\
\hline SKCS & $-0,12$ & 0,23 & $-0,06$ & $-0,25$ & \\
\hline Gluten ind. & $-0,05$ & 0,12 & $-0,23$ & & \\
\hline Wet gluten & $0,61^{*}$ & 0,19 & & & \\
\hline HFN & 0,00 & & & & \\
\hline
\end{tabular}

* Significant at $\mathrm{p} \leq 0.05$

The relationship among parameters was tested using correlation coefficients for both sites separately (Table 2). The same pattern was found for most parameters with the exception of HFN. The content of protein was significantly correlated with Zeleny test and the wet gluten content. The results confirmed that there is not relation between hardness and protein content (Vejražka and Hrstková, 2007; Gazza et al., 2008). 
Weightman et al. (2008) suggested that drought increases grain hardness together with protein content and vitreosity. Our results did not confirm this expectation, although the protein content was much higher from the B site, the average hardness was comparable from both sites (54.3 and 57.3 SKCS units). On the other hand the hardness was the most stable parameter, the correlation coefficient for SKCS for the A and B site over all three years $(n=48)$ was 0.88 ; for Zeleny volume 0.76 and for wet gluten content and gluten index only 0.60. As expected, the lowest correlation was found for protein content $(r=0.44)$, that suggests that under dry conditions also low-quality varieties can reach very high levels of protein in grain.

\section{Conclusions}

The aim of this study was to investigate the effect of limited water availability on grain quality of winter wheat. The quality was determined using following parameters: protein content, Hagberg falling number, Zeleny sedimentation volume, wet gluten content, gluten index and SKCS units, the grain of 16 varieties grown under normal and drought conditions over three years was used for analysis. The results showed that drought strongly increased protein content, Zeleny sedimentation volume and wet gluten content. Gluten index was significantly lower and no changes were detected for SKCS units and HFN. The relationships between parameters at both sites were similar, the protein content was positively correlated with Zeleny volume and wet gluten content. No strong correlations were found for HFN, gluten index and SKCS. The SKCS was the parameter with the smallest response to drought.

\section{Acknowledgements}

Authors gratefully acknowledge the financial support of the Grant Agency of Czech Ministry of Agriculture, project QH 91192 and MSM2629608001 project.

\section{References}

Anderssen RS. - Haraszi R.: 2009. Characterizing and exploiting the rheology of wheat hardness. European Food Research and Technology, 229: 1. 159-174.

Balla K. - Karsai I. - Veisz O.: 2009. Analysis of the quality of wheat varieties at extremely high temperatures. Cereal Research Communications, 37. 13-16.

Cseuz L. - Pauk - Lantos C. - Kovács I.: 2009. Wheat breeding for drought tolerance. (Efforts and results.). Cereal Research Communications, 3. 245-248.

Falco S. - Chavas JP.: 2008. Rainfall Shocks, Resilience, and the Effects of Crop Biodiversity on Agroecosystem Productivity. Land Economics, 84: 1. 83-96.

Gaines C. S. - Finnley P. F. - Fleege L. M. - Andrews L. C.: 1996. Predicting a Hardness Measurement Using the Single-Kernel Characterization System. Cereal Chemistry, 73: 2. 278-283.

Gazza L. - Taddei F. - Corbellini M. - Cacciatori P. - Pogna NE.: 2008. Genetic and environmental factors affecting grain texture in common wheat. Journal of Cereal Science 47: 1. 52-58.

Lyford CP - Kidd W - Rayas-Duarte P - Deyoe Ch.: 2005. Prediction of flour extraction rate in hard red winter wheat using the single kernel characterization. Journal of Food Quality 28: 3. 279-288.

Nadolska-Orczyk A. - Gasparis S. - Orczyk W.: 2009. The determinants of grain texture in cereals. Journal of Applied Genetics 50: 3. 185-197.

Turnbull K.M. - Rahman S.: 2002. Endosperm Texture in Wheat. Journal of Cereal Science 36. 327-337.

Vejražka K. - Hrstková P.: 2007. Selected physical properties and baking quality parameters of winter wheat grain. Proceedings of the $4^{\text {th }}$ international congress on FLOUR - BREAD '07. 142-146.

Weightman R.M. - Millar S. - Alava J. - Foulkes M.J. - Fish L. - Snape J.W.: 2008. Effects of drought and the presence of the $1 \mathrm{BL} / 1 \mathrm{RS}$ translocation on grain vitreosity, hardness and protein content in winter wheat. Journal of Cereal Science 47: 3. 457-468. 


\title{
ENVIRONMENTAL SALINISATION PROCESSES IN AGRO- ECOSYSTEM OF NERETVA RIVER ESTUARY
}

\author{
Gabrijel ONDRASEK ${ }^{1}$ - Zed RENGEL ${ }^{2}$ - Davor ROMIC ${ }^{1}$ - Radovan SAVIC ${ }^{3}$ \\ ${ }^{1}$ Faculty of Agriculture, University of Zagreb, Svetosimunska 25/10000 Zagreb/Croatia, gondrasek@agr.hr \\ ${ }^{2}$ Soil Science \& Plant Nutrition, Faculty of Natural \& Agricultural Sciences, University of Western Australia, \\ Crawley WA6009/Australia \\ ${ }^{3}$ Faculty of Agriculture, University of Novi Sad, Dositej Obradovic Sq. 8/21000 Novi Sad/Serbia
}

\begin{abstract}
Agriculture in Neretva River estuary (Republic of Croatia) is an important economic activity for more than 30,000 people. Due to proximity to Adriatic Sea and porous (karst) hydrogeological structure of alluvial river valley, sea water intrusion is common. As a consequence, most water sources used for irrigation are saline $\left(\mathrm{EC}>2 \mathrm{dS} \mathrm{m}^{-1}\right)$ periodically or even continuously, which can have enormous effects on soil physical and chemical properties as well as on viability of ecosystems in the estuary. Salinisation of the soil that surrounds roots (rhizosphere) diminishes growth and development of most crops, impairing yield and quality. Moreover, increased soil salinity may enhance uptake and accumulation of certain biotoxic elements (e.g. Cd) in edible crop parts and thus in the human food chain. In this study, chemical analyses of water (open channels and groundwater) and topsoil saturation extracts indicated potential secondary salinisation processes on around 2,500 ha of irrigated land in Neretva River estuary, with EC and SAR values exceeding those recommended for agriculture by FAO. However, intensive rainfall $(>650 \mathrm{~mm})$ during winter and homogenous and stable solum structure with favourable water permeability properties enable salt leaching and underpin resilience of agricultural ecosystems. Nevertheless, it is of utmost importance to control water and land salinisation processes in Neretva River valley to ensure sustainable agricultural production in the future.
\end{abstract}

Keywords: secondary salinity, salt leaching, EC, SAR

\section{Introduction}

For appropriate growth and development, plants need optimal concentrations of dissolved minerals (salts) in the rhizosphere. However, increased content of soluble salts in irrigation water or soil medium are harmful to most cultured plants, and can cause different physiological disorders (e.g. water, osmotic, ionic and/or oxidative stress), jeopardizing growth and development and impairing fruit yield and quality (Ondrasek et al., 2009a). In addition, excessive root zone salinity may enhance phytoaccumulation of certain biotoxic elements (e.g. Cd) in edible parts of some cereals/vegetables, and thus in the human foodstuffs (Ondrasek, 2008; Ondrasek et al., 2009b). Excessive soil salinity is one of the most widespread abiotic disorders in irrigated crop production, affecting at least $20 \%$ of arable land or nearly $50 \%$ of irrigated land worldwide (Flowers and Yeo, 1995). Salt-affected soils in Republic of Croatia (RH) occupy $<1000$ ha, mostly in the coastal area around the river estuaries (Ondrasek, 2008). Soil salinisation processes can be naturally-induced (primary salinisation), like sea water intrusion, and/or human-induced (secondary salinisation), like fert/irrigation practices with saline $\left(>2 \mathrm{dS} \mathrm{m}^{-1}\right.$ ) water (Varallyay et al., 2005). In Neretva River estuary, as one of the regions with the most intensive horticultural production in RH, proximity to Adriatic Sea and porous (karst) hydrogeological structure of alluvial river valley influence salinisation processes (Ondrasek, 2008; Romic et al., 2008). However, usage of channel water and/or groundwater of poor quality for irrigation is still common practice. Therefore, the aim of this study was to characterize the current salinisation status of the most important environmental 
resources (agricultural land and water) exploited in crop production in Neretva River estuary.

\section{Materials and methods}

In 2009, the investigations were conducted in Neretva River estuary (Opuzen end Metkovic area) on five plots (cca 2,500 ha) with intensive horticultural production, ameliorated with an open drainage channel network and supplemented with modern sprinkle or trickle irrigation systems. On each plot, one soil profile was dug down to parent soil material; at the beginning of vegetation (April), soil samples $(0-45 \mathrm{~cm})$ were taken per horizon for hydrophysical (water permeability) and physical (mechanical composition, porosity and density) analyses, as well as chemical (pH, EC, $\mathrm{Na}, \mathrm{Mg}, \mathrm{Ca}$ and SAR) properties of saturated soil extract (Se) according to standard analytical procedures (Romic et al., 2008). Apart from the soil profile, one piezometer (Pz) was set up to $4 \mathrm{~m}$ depth, and during vegetation season (April-October) groundwater sample from $\mathrm{Pz}$ and water sample from the nearest open channel (W) were taken monthly at each location. In Pz and W samples (1 L), chemical properties as described above for Se were detected, whereas Sodium Adsorption Ratio was determined as follows: $\mathrm{SAR}=\left(\left(\mathrm{Na}^{+}\right) / \sqrt{ }\left[\left(\mathrm{Ca}^{2+}\right)+\left(\mathrm{Mg}^{2+}\right) / 2\right]\right)$. To interprete climate conditions, and determine annual Penman-Monteith reference evapotranspiration (ETo), average annual climate data (air temperature, insolation, relative air humidity, precipitation and wind speed) were analyzed from meteorological station Opuzen $\left(43^{\circ} 05^{\prime} \mathrm{N} ; 17^{\circ} 39^{\prime} \mathrm{E}\right)$ for period 1981 2008, and processed by means of computer program CropWat ver. 5.7 (Smith, 1992).

\section{Results and discussion}

Table 1 contained average $(n=6)$ chemical characteristics of water $(\mathrm{Pz}$ and $\mathrm{W})$ and saturated topsoil extracts (Se). The $\mathrm{pH}$ values were fairly similar in water and soil environment, and ranged from almost neutral (7.1) to moderately alkaline (7.9). The concentration of total soluble salts or electrical conductivity (EC) was the highest in piezometer water samples, with exception of Plot $4(\mathrm{P} 4)$, where open channel water was more saline than groundwater by $0.6 \mathrm{dS} \mathrm{m}^{-1}$. At P3 and P5, electrical conductivity of groundwater was extremely high $\left(23 \mathrm{dS} \mathrm{\textrm {m } ^ { - 1 }}\right)$, and even higher by one order of magnitude then in saturated topsoil extracts. According to the USDA salinity laboratory criteria (Richards, 1954), salt-affected soils are not detected at the investigated plots because EC values of their saturated paste extracts were much lower than the boundary salinity level $\left(4 \mathrm{dS} \mathrm{m}^{-1}\right)$ differentiating between saline and non-saline soils. However, with respect to more strict classification of the FAO, which has a lower salinity threshold between non-saline and saline soils $\left(2 \mathrm{dS} \mathrm{m}^{-1}\right.$ in the saturation extract), agricultural soils at P4 and P5 could be considered slightly saline (Abrol et al., 1988). Also, EC data from groundwater $(\mathrm{Pz})$ and channel water $(\mathrm{W})$ indicated serious restriction in their usage for agricultural irrigation, especially because EC exceeded the threshold for severe salinity $\left(3 \mathrm{dS} \mathrm{m}{ }^{-1}\right)$ in all $\mathrm{Pz}$, and $\mathrm{W} 1, \mathrm{~W} 3$ and $\mathrm{W} 4$ samples; In contrast, samples W2 $\left(1.5 \mathrm{dS} \mathrm{m}^{-1}\right)$ and W5 $\left(2.1 \mathrm{dS} \mathrm{m}^{-1}\right)$ were slightly to moderately restrictive (Ayers and Westcot, 1994). The most dominant cation in $\mathrm{Pz}$ and $\mathrm{W}$ samples was sodium, whose concentration by $2.5-61$ times exceeded the Na threshold limit (70 
$\mathrm{mg} \mathrm{L}^{-1}$ ) for salt-sensitive plant species (Ayers and Westcot, 1994); in the case of overhead sprinkler irrigation (the most implemented at studied area) can cause serious crops damage (Romic et al., 2008). Contrary, in all Se samples with dominated calcium (concentration up to $>100$-folds higher then $\mathrm{Na}(\mathrm{Se} 2)$ ), can be explained by higher $\mathrm{Ca}^{2+}$ affinity (vs. $\mathrm{Na}^{+}$) to an/organic soil components (Ondrasek et al., 2009a), and relatively low proportion (15-33\%) of clay particles in the topsoil horizons (Table 2). Excessive $\mathrm{Na}$ in irrigation water can promote soil structural dispersion, especially if $\mathrm{Na}: \mathrm{Ca}$ is $>3$ (Ayers and Westcot, 1994), what is confirmed in W1, W3, Pz3 and Pz5 samples. The last parameter form Table 1 (SAR), together with salinity (EC) strongly influences to infiltration soil properties (Romic et al., 2008). In general, infiltration rate is proportional to EC and inversely proportional to SAR (Ayers and Westcot, 1994), due to dispersing activities of sodium, as well as strong stabilizing influence of calcium on soil aggregates and structure (Ondrasek, 2008). According to FAO water quality criteria (Ayers and Westcot, 1994), topsoil infiltration rate would not be affected by EC and SAR when analyzed water $(\mathrm{Pz}$ and $\mathrm{W})$ was used for irrigation of observed plots (Table 1).

Table 1. Chemical composition of water (W-open channel, Pz-piezometer) and saturated soil extract (Se) samples from analysed plots $(\mathrm{P})$

\begin{tabular}{|c|c|c|c|c|c|c|c|}
\hline \multirow{2}{*}{ Plot } & \multirow{2}{*}{ Sample } & \multirow{2}{*}{$\mathrm{pH}$} & $\mathrm{EC}$ & $\mathrm{Na}^{+}$ & $\mathrm{Ca}^{2+}$ & $\mathrm{Mg}^{2+}$ & \multirow{2}{*}{ SAR } \\
\hline & & & $\mathrm{dS} \mathrm{m}{ }^{-1}$ & \multicolumn{3}{|c|}{$\mathrm{mg} \mathrm{L}^{-1}$} & \\
\hline \multirow{3}{*}{$\mathrm{P} 1$} & W1 & 7.7 & 6.1 & 844 & 170 & 126 & 16.9 \\
\hline & Pz1 & 7.6 & 6.3 & 755 & 484 & 152 & 10.9 \\
\hline & Se1 & 7.5 & 0.8 & 73 & 119 & 33 & 2.2 \\
\hline \multirow{3}{*}{$\mathrm{P} 2$} & W2 & 7.6 & 1.5 & 171 & 102 & 32 & 5.2 \\
\hline & Pz2 & 7.4 & 4.0 & 285 & 554 & 77 & 4.3 \\
\hline & $\mathrm{Se} 2$ & 7.7 & 0.6 & 1.7 & 151 & 7.8 & 0.1 \\
\hline \multirow{3}{*}{ P3 } & W3 & 7.7 & 3.3 & 478 & 109 & 75 & 12.2 \\
\hline & Pz3 & 7.4 & 23 & 4231 & 492 & 533 & 44.5 \\
\hline & $\mathrm{Se} 3$ & 7.9 & 1.1 & 122 & 125 & 5.8 & 4.4 \\
\hline \multirow{3}{*}{$\mathrm{P} 4$} & W4 & 7.1 & 3.5 & 471 & 183 & 74 & 10.5 \\
\hline & $\mathrm{Pz} 4$ & 7.4 & 3.1 & 303 & 295 & 42 & 6.2 \\
\hline & $\mathrm{Se} 4$ & 7.7 & 2.2 & 15 & 186 & 27 & 0.4 \\
\hline \multirow{3}{*}{ P5 } & W5 & 7.6 & 2.1 & 279 & 106 & 44 & 8.1 \\
\hline & Pz5 & 7.4 & 23 & 4030 & 679 & 987 & 32.7 \\
\hline & $\mathrm{Se} 5$ & 7.4 & 2.3 & 19.4 & 619 & 49 & 0.3 \\
\hline
\end{tabular}

The studied area pertains to Mediterranean climate zone with hot and dry summer, and wet winter (Romic et al., 2008). The mean annual air temperature is $16.2^{\circ} \mathrm{C}$ (data not shown) with the hottest month being July $\left(25.5^{\circ} \mathrm{C}\right.$, data not shown) and annual ETo $>1200 \mathrm{~mm}$. Annual water deficit (between ETo and effective rainfall) is relatively low $(-197 \mathrm{~mm})$ compared to water deficit during vegetation $(-503 \mathrm{~mm})$. The most intensive 
water deficit, occurring in July $(-156 \mathrm{~mm})$, horticultural producers counteract with irrigation using mostly poor-quality water (Table 1), exposing soils to potential salinisation. However, intensive rainfall during winter $(>650 \mathrm{~mm})$ and homogenous and stable solum structure with favourable water permeability properties (Table 2) enable salt leaching and underpin resilience of agricultural ecosystems.

Table 2. Physical and hydraulic properties in soil profiles $(\mathrm{Pp})$

\begin{tabular}{|c|c|c|c|c|c|c|c|}
\hline \multirow{2}{*}{$\begin{array}{l}\text { Pedological } \\
\text { profile }\end{array}$} & \multirow{2}{*}{$\begin{array}{l}\text { Depth } \\
\mathrm{cm}\end{array}$} & \multicolumn{3}{|c|}{ Mechanical composition } & \multirow{2}{*}{$\begin{array}{c}\text { Porosity } \\
\%\end{array}$} & \multirow{2}{*}{$\begin{array}{c}\begin{array}{c}\text { Bulk } \\
\text { denisity }\end{array} \\
\mathrm{g} \mathrm{cm}^{-3}\end{array}$} & \multirow{2}{*}{$\begin{array}{c}\begin{array}{c}\text { Water } \\
\text { permeability }\end{array} \\
\mathrm{cm} \mathrm{s}^{-1}\end{array}$} \\
\hline & & $\%$ Clay & $\%$ Silt & $\%$ Sand & & & \\
\hline Pp1 & $0-40$ & 33 & 55 & 12 & 47 & 1.37 & $8.3 \times 10^{-4}$ \\
\hline $\mathrm{Pp} 2$ & $0-40$ & 17 & 67 & 16 & 44 & 1.52 & $1.2 \times 10^{-5}$ \\
\hline $\mathrm{Pp} 3$ & $0-45$ & 22 & 67 & 11 & 49 & 1.36 & $6.6 \times 10^{-4}$ \\
\hline $\mathrm{Pp} 4$ & $0-30$ & 17 & 66 & 17 & 44 & 1.48 & $5.9 \times 10^{-4}$ \\
\hline $\mathrm{Pp} 5$ & $0-45$ & 15 & 66 & 19 & 43 & 1.51 & $5.8 \times 10^{-5}$ \\
\hline
\end{tabular}

\section{Conclusions}

Because of salt degradation at particular plots and serious water-quality restrictions for crop irrigation, it is of utmost importance to control salinisation processes in Neretva River valley to ensure sustainable agricultural production in the future.

\section{References}

Abrol I.P. - Yadav J.S.P. - Massoud F.I.: 1988. Salt-Affected Soils and their Management. FAO Soils Bulletin 39, FAO, Rome.

Ayers R.S. - Westcot D.W.: 1994. Water qualitiy for Agriculture, FAO Irrig. and Drain. Paper 29, FAO, Rome.

Flowers T.J. - Yeo A.R.: 1995. Breeding for salinity resistance in crop plants. Where next? Aust. J. Plant Physiol. 22: 875-884.

Ondrasek G.: 2008. Salt stress and rhizosphere contamination by cadmium: Uptake and phytoaccumulation of nutrients and toxic metal. Doctoral Disertation. University of Zagreb.

Ondrasek G. - Romic D. - Rengel Z. - Romic M. - Zovko M.: 2009a. Cadmium accumulation by muskmelon under salt stress in contaminated organic soil. Sci. Total Environ. 407: 7. 2175-2182.

Ondrasek G. - Rengel Z. - Romic D. - Poljak M. - Romic M.: 2009b. Accumulation of non/essential elements in radish plants grown in salt-affected and cadmium-contaminated environment. Cereal research communications. 37: Suppl. S. 9-12.

Richards L.A.: 1954. Diagnosis and improvement of saline and alkali soils. USDA Handbook No. 60. Washington, D. C.

Romic D. - Ondrasek G. - Romic M. - Borosic J. - Vranjes M. - Petosic D.: 2008. Salinity and irrigation method affect crop yield and soil quality in watermelon (Citrullus lanatus L.) growing. Irrigation \& Drainage. 57: 4. 463-469.

Smith M.: 1992. CropWat. A computer program for irrigation planning and maangement. FAO Irrig. and Drain. Paper 46, FAO, Rome.

Varallyay G. - Toth T. - Toth G.: 2005. Salinisation/Sodification. Identifying Risk Areas for Soil Degradation in Europe by Salinisation/Sodification. In: Common Criteria for Risk Area Identification According to Soil Threats. European Soil Bureau Research Report No. 20, EUR 22185 EN. 43-50. Office for Official Publications of the European Communities, Luxembourg. 


\title{
EVALUATION OF THE OPERATIONAL STABILITY OF BIOCHEMICAL OXYGEN DEMAND BIOSENSORS IN WASTEWATER CONTAMINATED BY HEAVY METAL IONS
}

\author{
Svjetlana $\check{S} K R A B A L^{1}-$ Radoslav MILIČEVIC ${ }^{2}-$ Midhat JAŠI $\check{C}^{3}-$ Jurislav BABIĆ ${ }^{4}-$ \\ Borislav MILIČEVIC ${ }^{l}$ \\ ${ }^{1}$ Zvečevo dd, Food Industry, Kralja Zvonimira 1, Požega, Croatia, svjetlana.skrabal@ zvecevo.hr \\ ${ }^{2}$ Faculty for safety at work of Zagreb, I Lučića 5, Zagreb, Croatia, \\ ${ }_{3}^{3}$ Faculty of Technology University of Tuzla, Univerzitetska 8, Tuzla, BiH \\ ${ }^{4}$ Faculty of Food Technology University of Osijek, F Kuhača 18, Osijek, Croatia
}

\begin{abstract}
The biochemical oxygen demand (BOD) sensor based on an immobilized culture of microorganisms in combination with a dissolved oxygen electrode has been developed for the purpose of online monitoring of the organic pollution of wastewater. A general problem of all BOD sensors is in measuring samples containing heavy metal ions. The result of this study clearly demonstrates the need to use heavy metal resistant strains, while measuring the BOD of waste water contaminated by heavy metal ions. It's because even small concentration of heavy metal ions can have significant impact on operational stability of biochemical oxygen demand biosensors.
\end{abstract}

Keywords: BOD, wastewater, biosensors

\section{Introduction}

Over the last few years environmental monitoring and prevention of pollution are becoming increasingly important. This is particularly true for toxic substances with potential human health risk. The biochemical oxygen demand (BOD) is one of the most widely used and important tests in the measurement of wastewater organic pollution (Riedel et al., 1998). The conventional BOD test requires a 5 day incubation period and the test values depend upon the skill of the operator (Eaton et al., 1995).

Therefore, rapid and reproducible methods are desirable for the BOD monitoring. A very attractive technique for automated wastewater monitoring is the flow-injection analysis in combination with biosensors as the recognition element (Yang et al., 1997 and Yoshida et al., 2001). The major advantages of these systems are a short contact time between the wastewater and the biosensor and the whole system is entirely automated and computer controlled (Reynolds et al., 1997 and Konig et.al., 1999).

Biochemical oxygen demand sensor, based on an immobilized mixed culture of microorganisms in combination with a dissolved oxygen electrode, has been developed for the purpose of on-line monitoring of the organic pollution of waste water (Preininger et al., 1994 and Chee et al., 1999).This biosensors may be defined as an analytical device which combines a biological sensing component with a signal transducer (Amarjeet et al., 1996).

Optimum biosensor design requires effective immobilization techniques which can provides a thin film of biological component on the transducer surface in a reproducible manner (Chemnitius et.al., 1996). The biological sensing component provides unique interaction with wastewater. Function of the transducer is to convert this signal into a measurable response. 
Operational stability is one of the important factors to be considered in BOD biosensors (Byung et al., 2003). Stabile sensor performance over a desired period is essential for a reliable sensor system (Gil et al., 2003).

A general problem of all BOD sensors is in measuring samples containing heavy metal ions because they are known to cause inhibitory or toxic effects on microbiological components of sensors (Kim et al., 2002 and Liu et al., 2000).

To avoid this heavy metal interference it is important to make evaluation of heavy metals resistant of the biosensors and find microbiological components suitable for measuring the BOD in wastewater contaminated with heavy metal ions (Sharma and Rogers, 1997).

\section{Materials and methods}

Wastewater was collected from a production process at "Zvečevo dd, Food Industry" Croatia during 2007. The wastewater contained $23 \pm 7.5 \mathrm{mg}$ total nitrogen and $10.9 \pm 1.8$ $\mathrm{mg}$ total phosphorus, respectively, inorganic nitrogen was less than $5 \mathrm{mg}$. It was diluted using $50 \mathrm{mM}$ phosphate buffer $(\mathrm{pH} \mathrm{7})$ containing $100 \mathrm{mM} \mathrm{NaCl}$ to a designated concentration before being fed into the anode of biosensors.

In order to study the influence of heavy metal ions $1 \mathrm{mM} ; 2 \mathrm{mM} ; 3 \mathrm{mM} ; 4 \mathrm{mM} ; 5 \mathrm{mM}$; $6 \mathrm{mM} ; 7 \mathrm{mM} ; 8 \mathrm{mM} ; 10 \mathrm{mM}$ of cadmium were added into a standard wastewater.

All measuring experiments were conducted using three separate culture of microorganisms (Bacillus subtilis, Bacillus lichenifornis and Alcaligenes eutrophus) integrated in a flow trough system ("Strix" plc., Zagreb, Croatia). Results are compared with $\left(\mathrm{BOD}_{5}\right)$ results which are measured using standard methods (Eaton et al. 1995).

\section{Results and discussion}

Biochemical oxygen demand is one of the most widely used and important measurement in the environmental monitoring.

Nevertheless, only a few systems are present on the market today for automated wastewater monitoring. The reason for this can be found in intrinsic difficulty to preserve working conditions of the biosensors.

Table 1.shows the comparison of BOD values of wastewater samples measured by the sensor and those determined by $\mathrm{BOD}_{5}$ conventional test.

$\mathrm{BOD}_{5}$ values measured using conventional methods showed the standard deviation of $\pm 7,9 \%$ to $\pm 9,3 \%$, according to the (Eaton et al. 1995), $\pm 15.4 \%$ reproducibility is acceptable in $\mathrm{BOD}_{5}$ test.

In absence of heavy metal ions sensors were stable and result of measurements were in co-ordinance with $\mathrm{BOD}_{5}$ test results. 
Table 1. Comparison of BOD values of wastewater samples measured by the sensor and conventional $\mathrm{BOD}_{5}$

\begin{tabular}{|c|c|c|c|c|}
\hline Sample & $\mathrm{BOD}_{5}$ & $\begin{array}{l}\text { Sensor BOD } \\
\text { Bacillus } \\
\text { subtilis, }\end{array}$ & $\begin{array}{c}\text { Sensor BOD } \\
\text { Bacillus } \\
\text { lichenifornis }\end{array}$ & $\begin{array}{l}\text { Sensor BOD } \\
\text { Alcaligenes } \\
\text { eutrophus }\end{array}$ \\
\hline $\begin{array}{c}\mathbf{1} \\
\text { standard wastewater }\end{array}$ & $1203,03 \pm 7,9 \%$ & $1210,03 \pm 3,5 \%$ & $1211,00 \pm 3,7 \%$ & $1206,05 \pm 3,8 \%$ \\
\hline $\begin{array}{c}\mathbf{2} \\
(* 1 \mathrm{mM} \text { of cadmium were } \\
\text { added into a standard } \\
\text { wastewater })\end{array}$ & $1196,01 \pm 9,0 \%$ & $1001,03 \pm 3,7 \%$ & $1111,00 \pm 3,4 \%$ & $1200,00 \pm 4,0 \%$ \\
\hline $\begin{array}{c}\mathbf{3} \\
(* 2 \mathrm{mM} \text { of cadmium were } \\
\text { added into a standard } \\
\text { wastewater })\end{array}$ & $1201,01 \pm 8,0 \%$ & $991,03 \pm 3,6 \%$ & $1101,00 \pm 3,8 \%$ & $1198,00 \pm 4,1 \%$ \\
\hline $\begin{array}{c}\mathbf{4} \\
\text { (*3mM of cadmium were } \\
\text { added into a standard } \\
\text { wastewater) }\end{array}$ & $1200,01 \pm 8,1 \%$ & $893,03 \pm 4,0 \%$ & $961,00 \pm 4,1 \%$ & $1090,00 \pm 3,7 \%$ \\
\hline $\begin{array}{c}\mathbf{5} \\
(* 4 \mathrm{mM} \text { of cadmium were } \\
\text { added into a standard } \\
\text { wastewater })\end{array}$ & $1198,00 \pm 9,3 \%$ & $791,03 \pm 3,6 \%$ & $811,00 \pm 3,7 \%$ & $986,05 \pm 4,2 \%$ \\
\hline $\begin{array}{c}\mathbf{6} \\
(* 5 \mathrm{mM} \text { of cadmium were } \\
\text { added into a standard } \\
\text { wastewater })\end{array}$ & $1196,00 \pm 9,0 \%$ & $701,03 \pm 4,7 \%$ & $795,00 \pm 3,4 \%$ & $798,00 \pm 4,0 \%$ \\
\hline $\begin{array}{c}7 \\
(* 6 \mathrm{mM} \text { of cadmium were } \\
\text { added into a standard } \\
\text { wastewater })\end{array}$ & $1202,03 \pm 7,0 \%$ & $691,03 \pm 8,6 \%$ & $779,00 \pm 5,1 \%$ & $789,00 \pm 4,8 \%$ \\
\hline $\begin{array}{c}\mathbf{8} \\
(* 7 \mathrm{mM} \text { of cadmium were } \\
\text { added into a standard } \\
\text { wastewater })\end{array}$ & $1200,00 \pm 7,1 \%$ & $593,03 \pm 9,0 \%$ & $759,00 \pm 5,8$ & $770,00 \pm 5,1 \%$ \\
\hline $\begin{array}{c}\mathbf{9} \\
(* 8 \mathrm{mM} \text { of cadmium were } \\
\text { added into a standard } \\
\text { wastewater })\end{array}$ & $1198,50 \pm 9,3 \%$ & $491,03 \pm 8,8 \%$ & $733,00 \pm 5,7 \%$ & $769,00 \pm 7,7 \%$ \\
\hline $\begin{array}{c}\mathbf{1 0} \\
(* 10 \mathrm{mM} \text { of cadmium were } \\
\text { added into a standard } \\
\text { wastewater })\end{array}$ & $1202,20 \pm 9,0 \%$ & $351,03 \pm 10,0 \%$ & $729,05 \pm 5,2 \%$ & $763,00 \pm 4,8 \%$ \\
\hline
\end{tabular}

Measurements with wastewater containing 2 - 4mM cadmium ions showed immediately decreased of sensor response by about 15 to $35 \%$ these results are in accordance with published results ( Byung et al., 2003).

BOD values measured by the sensor showed the standard deviation from $\pm 3,5 \%$ to $\pm 3,8 \%$ during repeated experiments, and $\pm 3,6 \%$ to $\pm 4,2 \%$ for tests with 2 - $4 \mathrm{mM}$ cadmium (Table 1). The reproducibility of previously reported results varied from $\pm 2.4 \%$ to $\pm 10 \%$ for single strain sensors, (Liu and Mattiasson 2002).

In the spreadsheet 1 it's clearly visible that with bigger percentage of ion cadmium (5$10 \mathrm{mM}$ ) in the waste water we can't really talk about reliable respond of biological component. In this case heavy metal ions are causing significant inhibitory reaction in 
the system. Measurements showed decreased of sensor response by about 37 to $71 \%$, and reproducibility of results in repeated experiments varied from $\pm 4.7 \%$ to $\pm 10 \%$

Typical BOD sensor has a limited stability (Liu and Mattiasson 2002), a stable sensor performance over a desired period is essential for a reliable sensor system. According to results of experiments, above the value of $4 \mathrm{mM}$ cadmium operational stability of sensors system didn't exist.

\section{Conclusions}

In order to keep eco-system stability and preventing harmful effect of wastewater on soil and flora karasteristic, BOD measuring biosensors may be the devices of choice.

The obtained results of this study clearly demonstrate the need to use heavy metal resistant strains while measuring the BOD of wastewater which is contaminated with even smallest quantities of heavy metal ions, although challenges concerning operational lifetimes have yet to be investigated.

\section{References}

Amarjeet S.B. - Tang D. - Lee E. - Zhu Y.X. - Bergougnou M.A.: 1996. Biosensor in environmental and bioprocess monitoring and control. Food technol. and biotechol. 34: 9-21.

Byung H.K. - Chang I.S. - Geun C.G. - Hyung P.S. -Hyung J. K.: 2003. Novel BOD (biological oxygen demand) sensor using mediator-less microbial fuel cell Biotech. Let. 25: 541-545.

Chee G.J. - Nomura Y. - Karube I .: 1999. Biosensor for the estimation of low biochemical oxygen demand. Anal. Chem. Acta 379: 185-191.

Chemnitius G. - Meusel M. - Zaborosch C. - Knoll M. - Spener F. - Cammann K.: 1996. Highly sensitive electrochemical biosensor for water monitoring. Food technol. and biotechol. 34: 23-29.

Eaton A.D. - Clesceri L.S. - Greenberg A.E.: 1995. Standard Methodsfor the Examination of Water and Wastewater, 19th edn.Washington, DC: American Public Health Association.

Gil G.C. - Chang I.S. - Kim B.H. - Kim M. - Jang J.K. - Park H.S. - Kim H.J.: 2003. Operational parameters affecting the performance of a mediator-less microbial fuel cell. Biosens. Bioelectron.14: 887897.

Konig A. - Bachmannt T. T. - Metzger J.W. - Schmid R.D.: 1999. Disposable sensor for measuring the biochemical oxygen demand for nitrification and inhibition of nitrification in wastewater Applied microbiology and biotechnology 51,112-117.

Kim H.J. - Park H.S. - Hyun M.S. - Chang I.S. - Kim M. - Kim B.H.: 2002. A mediator-less microbial fuel cell using a metal reducing bacterium, Shewanella putrefaciens. Enzyme Microb. Technol. 30: 145-152.

Liu J. - Bjornsson L. - Mattiasson B.: 2000. Immobilized activated sludge based biosensor for biochemical oxygen demand measurement. Biosens. Bioelectron. 14: 883-893.

Liu J. - Mattiasson B.: 2002. Microbial BOD sensors for wastewater analysis. Water Res. 36: 3786-3802.

Preininger C. - Klimant I. and Wolfbeis O.S., (1994) Optical fiber sensor for biological oxygen demand. Anal. Chem. 66: 1841-1846.

Reynolds D.M. - Ahmad S.R.: 1997. Rapid and direct determination of waste water BOD values using a fluorescence technique. Water Res. 31: 2012-2018.

Riedel K. - Renneberg R. - Kühn M. - Scheller F.: 1998. A fast estimation of biochemical oxygen demand using microbial sensors. Appl. Microbiol. Biotechnol. 28: 316-318.

Sharma A. - Rogers K.: 1996. Immobilized bioreagent- based molecular devices. Food technol. and biotechol. 34: 113-123.

Yang Z. - Suzuki H. - Sasaki S. - McNiven S. - Karube I.: 1997. Comparison of the dynamic transient- and steady-state measuring methods in a batch type BOD sensing system. Sensor. Actuator.B45: 217-222.

Yoshida N. - Hoashi J. - Morita T. - McNiven S.J. - Nakamura H. - Karube I.: 2001. Improvement of a mediator-type biochemical oxygen demand sensor for on-site measurement Journal of Biotechnology, 88: 269-275. 


\title{
GLOBAL WARMING AND IRRIGATION DIFFICULTIES
}

\author{
Mubarak RASHID AL BOAININ ${ }^{1}$ - László GUTH ${ }^{2}$ \\ ${ }^{1}$ Institute of Regional Economics and Rural Development, Faculty of Economic and Social Science, Szent \\ István University, 2103 Gödöllö, Páter Károly u. 1. Hungary \\ ${ }^{2}$ Institute of Regional Economics and Rural Development, Faculty of Economic and Social Science, Szent \\ István University, 2103 Gödöllö, Páter Károly u. 1. Hungary, \\ e-mail: guth.laszlo@fh.szie.hu
}

Abstract: Reducing water demand is also a very effective strategy (perhaps the most effective strategy) to minimize risk and to reduce environmental damage. Most water quality problems derive from several factors: - over-pumping of aquifers, agricultural runoff, discharge of human and industrial wastewater, and loss of habitat.

During drought, when aquifers were pumped hard, water levels in Lebanon were typically falling by 10 to 40 $\mathrm{cm}$ per year. Over-pumping or 'mining' of what should be renewable aquifers is all common in this region. MENA (Middle -East and North Africa) countries have coastal aquifers, which in their natural state are 3 to 5 metres above sea level; this, in turn, creates an outward pressure that blocks at the low level of seawater. Pumping has lowered the fresh water level below sea level so the effect is reversed and salt water from the Mediterranean can now be found $1 \mathrm{~km}$ to $3 \mathrm{~km}$ inland.

Irrigation systems produce more than their share of environmental problems. In this region, agricultural runoff is the major non-point source of water pollution, including sediment, phosphorous, nitrogen and pesticides. Per hectare use of pesticides and fertilizer in Jordan and Palestine rates among the highest in the world, and runoff is correspondingly high. Nitrate concentrations in the Coastal Aquifer underlying Lebanon and Gaza (from both fertilizers and reuse of sewage efficient) have doubled. Practices such as conservation tillage, contour planting, terracing and filter systems, among others, can control soil erosion and reduce phosphorous and nitrogen runoff by up to $60 \%$. The annual potential evapo-transpiration rates, which are the loss of water to the atmosphere, are greater by between two and 20 times the annual rainfall across the region.

Keywords: Water quality problems, Human and industrial wastewater, Evapo-transpiration rates, Drought, Over-pumping

\section{Introduction}

Water utilisation of the common sector based on the domestic use by urban populations, and the industrial sectors generally exceeds more than $10 \%$ of all national water use in MENA countries. The water use contributes to as an input to urban society and to their livelihoods in urban areas, which is considerably indeed and much greater than the proportional use. Based on estimation of UN and national organizations, the water delivered to and used in cities will double by the end of 2030 . Most of the water needed will come from water re-allocated from agriculture but continuously for many coastal cities and urban settlements the water will come from desalination plants. By the year 2000 about 20 billion cubic meters per year were used for municipal including domestic use in the MENA region. Desalinated water is very costly, although its expenditure has started to fall since the middle of 1990s based on extending highly technologies of desalinating process.

The growth of population needs much more food production and in consequence of which, water use within unfavourable dry weather conditions based on the global warming process (Ligetvári et al., 2006). 


\section{Materials and methods}

Domestic and industrial uses are different from agricultural uses. The overall losses to transpiration are very small indeed in urban areas compared with those in the vast irrigated tracts of the region.

In generally the water use can be separated into four sections, which are as follows: household; municipal; industry; and agriculture. The municipal use also includes both of the water delivered to commercial buildings and hotels, and mainly for the same purposes as households, and to the generally larger amounts used for municipal gardens, street cleaning, fire fighting etc.), which are as follows based on he local special characters, as Sector of use Percentage: Households $3 \pm 20$; Municipal $3 \pm 10$; Industrial

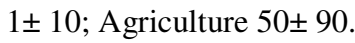

\section{Results and Discussion}

A surprisingly small proportion of water needs to meet drinking water standards, as defined by the World Health Organization. At 5 to 7 litres per person-day, only about 2 million cubic meter (MCM) per year is needed for every one million inhabitants, which is not very much water. In most parts of the world, including the Middle East, major uses do not require water of potable quality.

The potential evapo-transpiration is important for point of view for efficient water use, at first in agricultural sector. The annual potential evapo-transpiration rates, which are the loss of water to the atmosphere, are greater by between two and 20 times the annual rainfall across the region. Only when water reaches sub-surface aquifers is the storage secure from such unwanted losses. Water may be lost on its way to sub-surface storage through evaporation from ground, vegetation and water surfaces. It may also be lost in supporting vegetation that brings no return to local communities.

Because the soil water can not play significant role of MENA region, it can be important to discover groundwater storage, which can ensure water resource for irrigation. Even this can be very important, when low rainfall can not ensure adequate agricultural yield (see in detailed in Dobó et al., 2006).

Groundwater varies in accessibility according to depth, the size of the aquifer and its porosity and transmissibility. The physical nature of the strata in which the groundwater reservoir resides determines the rate at which water can be withdrawn.

They range from the alluvium of the region's river basins such as the Nile and the TigrisEuphrates, to the widespread limestone formations which are very porous- -with many small voids, and pervious - with many chambers which allow the storage and movement of water. Less porous sandstone strata underlie the extensive deserts of the region. Impervious volcanic formations are also widespread. They hold water only in fractures associated with tectomcally disturbed zones.

The Ecological Crisis: In the spring of 1994, five nations (Bahrain, Jordan, Lebanon, Syria and the United Arab Emirates) participated in an environmental conference organized by the American University of Beirut, and each of them identified water 
pollution as a critical issue. The key point is that, again by analogy to energy, it is just as important to conserve the quality of water as to conserve its quantity. Most of water quality problems derive from one or more of four factors: over-pumping of aquifers, agricultural runoff, discharge of human and industrial wastewater, and loss of habitat.

Over-pumping of Aquifers. Over-pumping of wells causes a decline in the water table. During the recent drought, when aquifers were pumped particularly hard, water levels in Lebanon were typically falling by 10 to $40 \mathrm{~cm}$ per year. Over-pumping or 'mining' of what should be renewable aquifers is all too common in this region.

A decline in the water table has several adverse effects. At a minimum, it adds to pumping costs and increases energy use. More importantly, a lower water table permits lower quality water to low inward and contaminate the fresh water of the aquifer. Many of the countries in the region have coastal aquifers, which in their natural state are 3 to 5 metres above sea level; this, in turn, creates an outward pressure that blocks at the low level of seawater. Pumping has lowered the fresh water level below sea level so the effect is reversed and salt water from the Mediterranean can now be found $1 \mathrm{~km}$ to $3 \mathrm{~km}$ inland.

Agricultural Runoff. Irrigation is obviously good for farmers but irrigation systems also produce more than their share of environmental problems. In most countries in the region, agricultural runoff is the major non-point source of water pollution, including sediment, phosphorous, nitrogen and pesticides. Per hectare use of pesticides and fertilizer in Jordan and Palestine rates among the highest in the world, and runoff is correspondingly high. As one result, over the past two decades, nitrate concentrations in the Coastal Aquifer underlying Lebanon and Gaza (from both fertilizers and reuse of sewage efficient) have doubled (Gabbay, 1992). In Syria, Al-Sin Lake, the main coastal source of fresh water, is polluted by runoff. Such problems are anything but inevitable. Practices such as conservation tillage, contour planting, terracing and filter systems, among others, can control soil erosion and reduce phosphorous and nitrogen runoff by up to $60 \%$.

Conservation of water, including both increases in efficiency with existing uses and changing use patterns, the water conservation has always been a major consideration in the water-short Middle East. However, as we learned from deeper analysis of energy use, the fact that a region is short of energy (water) does not imply either that existing uses are efficiently satisfied or that the pattern of use is appropriate. Additional to water-short of this region, many factors can also be negative including capital barriers, ill-designed policies, inaccessible technology, lack of information, and habits and traditions, intervene.

Although none of the countries under study comes close to maximizing economic, much less technical, potentials of efficiency in using water, the sheer dominance of irrigation requires special attention. Lebanon is regarded as a model of efficiency in irrigation, and in some senses this is true. Jordan pioneered the development of drip irrigation, and has gone on to improve the technique by sensors and computer controls that respond to

233 DOI: 10.1556/Novenyterm.59.2010.Suppl.3 
plant requirements rather than to a predetermined watering schedule. Today, water use per irrigated hectare is $40 \%$ less than it was in 1955, and gains continue to be made, if at a declining rate. Drip irrigation also reduces both the likelihood of salinization and pollution from runoff. Other nations in the region, notably Jordan, have adapted drip irrigation for many crops and are now producing their own pipe and other equipment. Unfortunately, drip irrigation is a capital-intensive technology, and it is not appropriate for all crops.

"In Syria the sustainable agriculture means to remain highly developed agricultural production level to supply foods for increasing population of the country with less negative influences on the natural environment." (Haddad and Zsarnóczai, 2008).

"Concerning the irrigation and drainage development, estimates on irrigation potential, based solely on soil resources, were about 5,9 million ha, which is roughly equal to the cultivable area. Considering the water resources available at present, irrigation potential is estimated at 1.250 .000 ha. Syria depends on international agreements with neighbouring countries on the sharing of river waters in the future" (Haddad and Zsarnóczai, 2008).

\section{Conclusions}

In conclusion, the social gains from approaching water problems from the demand side are very high and not restricted to direct financial savings. Reducing demand is also a very effective strategy (perhaps the most effective strategy) to minimize risk and to reduce environmental damage. The implication is that the long-term demand for water is much more elastic to price and policy than is recognized. In contrast, some analysts believe that water-short areas, such as the Jordan Valley countries, will have no alternative but to turn to external sources by some time early in the next century. They argue that even a higher level of end-use efficiency and a total shift of fresh water out of agriculture will be insufficient.

\section{References}

Dobó Erika - Fekete-Farkas Mária - Singh Mahesh Kumar - Szűcs István: 2006. Ecological-economic analysis of climate change on food system and agricultural vulnerability: a brief overview. Cereal Research Communications 34: 1. 777-781

Haddad G. - Zsarnóczai J. S.: 2008: Geographical background for agriculture in Syria. Cereal Research Communications 36: 1. 1019-1022.

Ligetvári F. - Várallyay Gy. - Schweitzer F.: 2006. Sivatagok és az elsivatagosodás nemzetközi éve, UNESCO 2006. Agrokémia és Talajtan 55: 2. 


\title{
IMPACT OF MICROCLIMATE ON CO2 EMISSION OF THE SOIL UNDER CONTROLLED WATER REGIME CONDITIONS
}

\author{
Nikolett SZÖLLÖSI
}

Department of Water- and Environmental Management, University of Debrecen CASE, H- Debrecen, Böszörményi út 146, szollosi@gisserver1.date.hu

\begin{abstract}
Biological processes in the soil lead to the accumulation of $\mathrm{CO}_{2}$ and a concomitant decrease in $\mathrm{O}_{2}$. Good gas exchange between soil and the ambient atmosphere is very important for the maintenance of an appropriate soil atmosphere regarding the $\mathrm{O}_{2}: \mathrm{CO}_{2}$ balance. The rate of $\mathrm{CO}_{2}$ accumulation depends both upon soil biological activity and physical characteristics such as porosity, structure, aggregate size, moisture content and temperature. Soil respiration is a critical determinant of landscape carbon balance too. Variations in soil temperature and moisture pattern are important physical processes controlling soil respiration which need to be better understood.

To gain more detailed information on the dynamics of $\mathrm{CO}_{2}$-emission from the soil in-situ measurements were done in a lysimeter experiment at the Karcag Research Institute of the University of Debrecen, CASE. An ANAGAS 98 infrared gas analyser was used in order to measure the $\mathrm{CO}_{2}$-concentration. For the spatial delimitation of the measuring area the original cylinders were substituted with a frame+bowl set. The aim of this experiment was to get information about $\mathrm{CO}_{2}$ cycle in lysimeters during 24 hours in different soil surfaces with same water supply. Comparing the grass covered and non-covered soil surfaces high $\mathrm{CO}_{2}$-emissions but no significant differences were figured out. The results underlined the dominant role of the organic material content of the soil contrary to the role of grass cover.
\end{abstract}

Keywords: $\mathrm{CO}_{2}$-emission, soil surface, daily dynamics

\section{Introduction}

Soil serves not only economic purposes, but biodiversity preservation too (Várallyay and Lang, 2000). In the soil of the Earth there are at around $1.58 \times 10^{18} \mathrm{~g}$ soil organic carbon (SOC) (Reiners, 1968). Mainly the common affects of climatic and edafic conditions result variance in the soil of different grassland types (Reeder and Schuman, 2002). Generally, when the soil organic carbon content of the soil rises, the clay content of the soil increases as well (Bauer et al., 1987) and parallel with the increasing precipitation too. The rate of soil breath of lawn in temperate regions is between 17-40 $\%$ (Raich and Tufekcioglu, 2000). Measurements have not been carried out to determine the order of the magnitude of the soil breath of arid grasslands. Soil breath is that part of primer production which could change an ecosystem from net carbon reservoir to emitter.

In space and time the $\mathrm{CO}_{2}$ gas exchange and any of its component (photosynthetic $\mathrm{CO}_{2}$ fixation, photosynthetic and non-photosynthetic organellums' dark respiration and photorespiration, furthermore their autotrophic and heterotrophic respiration) shows variability in all vegetation (Stoyan et al., 2000). This variability (generated by natural or artificial reasons) appears as the result of adaptation by continually variable environment conditions (Cheng et al., 2007). In addition the vegetation density affects soil moisture, temperature of soil surface, energetic and water regime, nutrient changes of soil and this relation is bilateral (Cosh and Brutsaert, 2003).

In the summer of 2009 measurements were carried out more than 40 times in six lysimeters at the Karcag Research Institute to quantify $\mathrm{CO}_{2}$ emission of the soil, soil temperature and soil moisture. Consequently the aim of the research was to get 
information about the daily dynamics of $\mathrm{CO}_{2}$ emission of the soil because processes that affect carbon oxidation are complex and variable.

\section{Materials and methods}

In the Department for Soil Utilisation and Rural Development of Karcag Research Institute of the University of Debrecen, Centre for Agricultural Sciences and Engineering in close co-operation with the Department of Water- and Environmental Management broad examination of new soil utilization methods was started based on $\mathrm{CO}_{2}$ emission of the soil under controlled water regime conditions. The experiment was carried out between 26th and 27th August (Table 1.). The soil type of the investigated lysimeters is meadow chernozem solonetzic in the deeper layers, a soil type that is characteristic for the Trans-Tisza Region of Hungary. In this experiment in situ measurements were carried out to separate $\mathrm{CO}_{2}$ emission originating from root respiration and microbiological activity by bare and grass covered soil surfaces.

Table 1. Meteorological data during the investigated period

\begin{tabular}{|c|c|c|c|c|c|c|c|}
\hline & $\begin{array}{c}\text { Daily } \\
\text { average } \\
\text { tempe- } \\
\text { rature } \\
\left({ }^{\circ} \mathrm{C}\right)\end{array}$ & $\begin{array}{c}\text { Global } \\
\text { radiance } \\
\left(\mathrm{W} \mathrm{m}^{-2}\right)\end{array}$ & $\begin{array}{c}\text { Sum } \\
\text { precipi- } \\
\text { tation } \\
(\mathrm{mm})\end{array}$ & $\begin{array}{c}\text { Min. } \\
\text { tempe- } \\
\text { rature } \\
\left({ }^{\circ} \mathrm{C}\right)\end{array}$ & $\begin{array}{c}\text { Max. } \\
\text { tempera- } \\
\text { ture }\left({ }^{\circ} \mathrm{C}\right)\end{array}$ & $\begin{array}{c}\text { Average } \\
\text { tempera } \\
- \text { ture } \\
\left({ }^{\circ} \mathrm{C}\right)\end{array}$ & $\begin{array}{c}\text { Rela- } \\
\text { tive } \\
\text { mois- } \\
\text { ture } \\
\text { min. } \\
(\%)\end{array}$ \\
\hline \hline $\begin{array}{c}26.08 . \\
2009\end{array}$ & 25.33 & 272.87 & 0.00 & 16.00 & 33.60 & 25.34 & 22.00 \\
\hline $\begin{array}{c}27.08 . \\
2009\end{array}$ & 25.79 & 266.20 & 0.00 & 17.60 & 33.50 & 25.79 & 23.00 \\
\hline
\end{tabular}

In order to quantify this, in situ $\mathrm{CO}_{2}$-emission of the soil was measured by means of an ANAGAS 98 infrared gas analyser. For the spatial delimitation of the measuring area frame+bowl sets were used. Such sets were successfully applied previously for grass covered soil surfaces (Zsembeli et al., 2006). At the same time soil moisture was measured by TTN-M (40 cm depth), while soil temperature (at $50 \mathrm{~mm}$ and $100 \mathrm{~mm}$ depths) and air temperature were measured with a digital thermometer. These data were required to discover the relationship between $\mathrm{CO}_{2}$ emission of the soil, soil and air temperature and soil moisture content.

\section{Results and discussion}

$\mathrm{CO}_{2}$ emission of the soil was measured under controlled water regime conditions during 24 hours (26.08.2009-27.08.2009) with the frequency of two hours. In Figure 1. the $\mathrm{CO}_{2}$-emission values of the two surfaces and their differences (flux of grassland minus flux of bare soil surface) are shown. The negative values mean that the emission from the grass covered surface was lower than from the bare soil.

On bare soil surface low $\mathrm{CO}_{2}$ concentration values were measured between 10 p.m. and 6. At noon the bare soil emitted more $\mathrm{CO}_{2}$. The lowest gas concentration value was measured at a.m. 6. In addition the $\mathrm{CO}_{2}$ emission of the soil decreased too when air 
temperature got a peak at $35.05{ }^{\circ} \mathrm{C}$ (Figure 1.). There wasn't linear significant correlation between soil moisture, temperature data and the $\mathrm{CO}_{2}$ emission of the soil.

In the morning hours there was higher gas emission from the grass covered soil surface until noon. In this area lower $\mathrm{CO}_{2}$ concentration values were measured between midnight and a.m. 6. The lowest gas concentration value was measured at a.m. $2(0.19 \mathrm{~g}$ $\left.\mathrm{m}^{-2} \mathrm{~h}^{-1}\right)$ and p.m. $2\left(0.2 \mathrm{~g} \mathrm{~m}^{-2} \mathrm{~h}^{-1}\right)$. However, the soil breath got a peak at a.m. $10(0.49 \mathrm{~g}$ $\left.\mathrm{m}^{-2} \mathrm{~h}^{-1}\right)$ and it was very high at p.m. $8\left(0.39 \mathrm{~g} \mathrm{~m}^{-2} \mathrm{~h}^{-1}\right)$ too and at this time was the highest the soil moisture as well. When in early afternoon high fluxes were measured two hours later temperature parameters got a peak too (Figure 1).

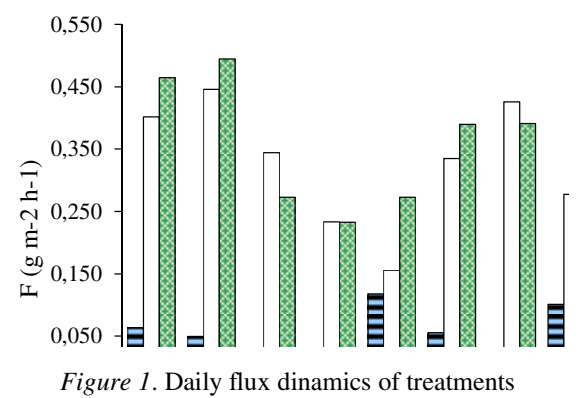

On the bare surface soil moisture content was 1.5- 2 times higher at the depth of $50 \mathrm{~mm}$, while these values were 2-3 times higher in the deeper layer $(100 \mathrm{~mm})$ than in the grass covered treatment (Figure 2-3.). In the latter case there were not roots in the upper layer.

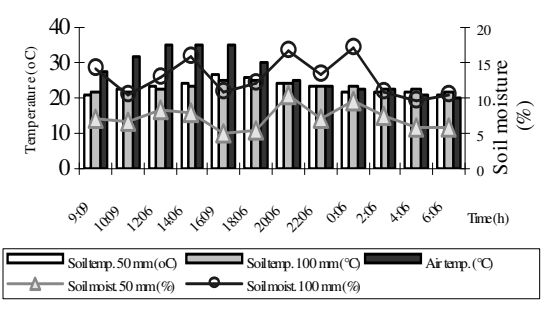

Figure 2. Temperature and soil moisture content in the bare soil surface treatment

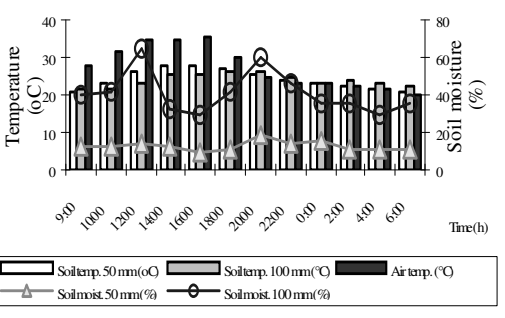

Figure 3. Temperature and soil moisture content in the grass covered treatment

The soil temperature was $2-3{ }^{\circ} \mathrm{C}$ lower in the plant covered soil surface which results in a better microclimate for microorganisms.

On the whole, there was a less active period during the night and the afternoon on the microbiological activity in the soil (Figure 1.). However, during the night this term comes later (at midnight) in the case of a grass cover and ends at the same time with the other treatment. In addition in the case of the grass cover the bottom of $\mathrm{CO}_{2}$ flux occurred earlier (at 2 p.m. with the same $\mathrm{CO}_{2}$ flux). At 2 p.m. the $\mathrm{CO}_{2}$ emission of the soil was equal in both treatments. During the day the air blending quickened and later the activity of vegetation too and there was a sinking in $\mathrm{CO}_{2}$ concentration. The highest concentrations were measured at 10 a.m. and 8 p.m., and the lowest values in the 
afternoon thus the $\mathrm{CO}_{2}$, which was accumulated during the night (and it is characteristic only for measuring area and its microclimate), completely assimilated in the border layer.

\section{Conclusions}

Studying the effect of different soil surface affects on the carbon stocks and the $\mathrm{CO}_{2}$-emission from soil is indisputably actual and needs more efforts as it can contribute to the correct assessment of environmental loads originating of the microbiological activity corresponding to the actual soil state.

\section{Acknowledgements}

I would like to express my gratitude to the researchers of Karcag Research Institute for supporting my analyses. Especially I would like to thank to Prof. Lajos Blaskó, Dr. József Zsembeli and Györgyi Kovács to support the measurement. In addition I would like to thank to Dr. Csaba Juhász for his continuous support in the Ph.D. program and to Prof. János Tamás for controlling my Ph.D. program.

\section{References}

Bauer A. - Cole C. V. - Black A. L.: 1987. Soil property comparisons in virgin grasslands between grazed and nongrazed management systems. Soil Science Society of America Journal, 51: 176-182.

Cheng X. - An S. - Chen J. - Li B. - Liu Y. - Liu S.: 2007. Spatial relationships among species, aboveground biomass, N, and P in degraded grasslands in Ordos Plateau, northwestern China. Journal of Arid Environmnets, 68: 652-667.

Cosh M. H. - Brutsaert W.: 2003. Microscale structural aspects of vegetation density variability. Journal of Hydrology, 276: 128-136.

IPCC: 2003. Good Practice Guidance for Land Use, Land-Use Change and Forestry, UNEP (Ed. By Jim Penman, Michael Gytarsky, Taka Hiraishi, Thelma Krug, Dina Kruger, Riitta Pipatti, Leandro Buendia, Kyoko Miwa, Todd Ngara, Kiyoto Tanabe and Fabian Wagner)

Raich J. W. - Tufekciogul, A.: 2000. Vegetation and soil respiration: correlations and controls. Biogeochemistry, 48: 71-90.

Reeder J. D. - Schuman, G. E.: 2002. Influence of livestock grazing on C sequestration in semi-arid mixedgrass and short-grass rangelands. Environmental Pollution, 116: 87-93.

Reiners W. A.: 1968.Carbon dioxideevolution from the floor of three Minnesota forests. Ecology, 49: 471483.

Stoyan H. - de-Polli H. - Böhm S. - Robertson G. P. - Paul E. A.: 2000. Spatial heterogeneity of soil respiration and related properties at the plant scale. Plant and Soil, 222: 1-2. 203-214.

Várallyay Gy. - Láng I.: 2000. A talaj kettős funkciója: természeti erőforrás és termőhely, A Debreceni Egyetem „Honoris Causa” cím átadása alkalmából (Debrecen, 2000. május 2.) megtartott előadás.

Zsembeli J. - Tuba G. - Kovács Gy: 2006. Development and extension of CO2-emission measurements for different soil surfaces. Cereal Research Communications, 34: 1. 359-362. 


\title{
IMPACT OF PREDICTED CLIMATIC CHANGES TO THE GROUNDWATER LEVEL IN LOWLAND TERRITORY
}

Andrej TALL

Institute of Hydrology, Slovak Academy of Sciences, Hollého 42, 07101 Michalovce, e-mail: tall@uh.savba.sk

\begin{abstract}
This paper deals with the research of predicted climatic changes and their impact to the groundwater level in lowland territory. Outputs were applied from the climatic scenario CCCM 2000 for climatic station in Milhostov, which is situated in eastern part of Slovakia. Output data were calculated from the normal 30-years period (1960-1990) for reference years 2010, 2030 and 2075. The impacts of predicted climatic changes were performed using numerical simulation on mathematical model FLOCR.
\end{abstract}

Keywords: climatic change, climatic scenario, groundwater level regime, numerical simulation, water availability

\section{Introduction}

Questions concerned to climatic changes are recently most discussed, especially in associate with appearance of various climatic anomalies as compared with long-term average climate. Increasing greenhouse effect will probably lead to global warming. Concerning the changes in atmosphere there has been an increase in the periodicity of the occurence of extreme hydrologic events in the past few years. For purpose of future climate prognosis, many climatic models were developed. Widely used climatic model in Slovakia is CCCM 2000 from Canadian Centre for Climate Modeling and Analysis. This model can provide time series data for up to 47 different climatic and hydrology elements (Lapin et al., 2003; Kandra and Gomboš, 2008; Nagy et al., 2007; Gomboš et al., 2007; Šoltész et al., 2007).

This contribution is focused on prognosis of groundwater level (GWL) in East Slovakian Lowland (ESL) according to the climatic scenario for future years 2010, 2030 and 2075.

\section{Materials and methods}

For GWL modeling was chosen locality Milhostov, which belongs to the ESL, in the eastern part of Slovakia. Soil profile is represented by clay-loam texture. All the necessary meteorological data were provided from the near meteorological station. As an initial data were used daily values of meteorological elements from 30-years normal period (1961-1990). Considered were only growing seasons (from April to September), not whole years. From all growing seasons (GS) of normal period was chosen one GS, which was considered as a representative. Criterium for selection was based on $\mathrm{ET}_{\text {pot }}$ values, which were calculated from meteorological elements, using Penman-Monteith equation. As a representative was chosen GS, whose sum of $\mathrm{ET}_{\text {pot }}$ was the nearest to the average from the whole normal period. Representative GS was used for application of climatic scenario. Used was Canadian climatic scenario CCCM 2000. Meteorological elements from the representative GS were recalculated using CCCM 2000. Obtained were meteorological elements for future years 2010, 2030 and 2075. These "hypothetical" values were used as an inputs for mathematical model FLOCR 
(Oostindie, K. - Bronswijk, J. J. B., 1992) and obtained were courses of GWL for years 2010, 2030 and 2075.

\section{Results and discussion}

Fig 1 presents some selected meteorological elements for 30 -years normal period. From this 30 years period was chosen one representative GS according the ET $_{\text {pot }}$ values. Representative GS for normal period 1961-1990 was GS in 1971.

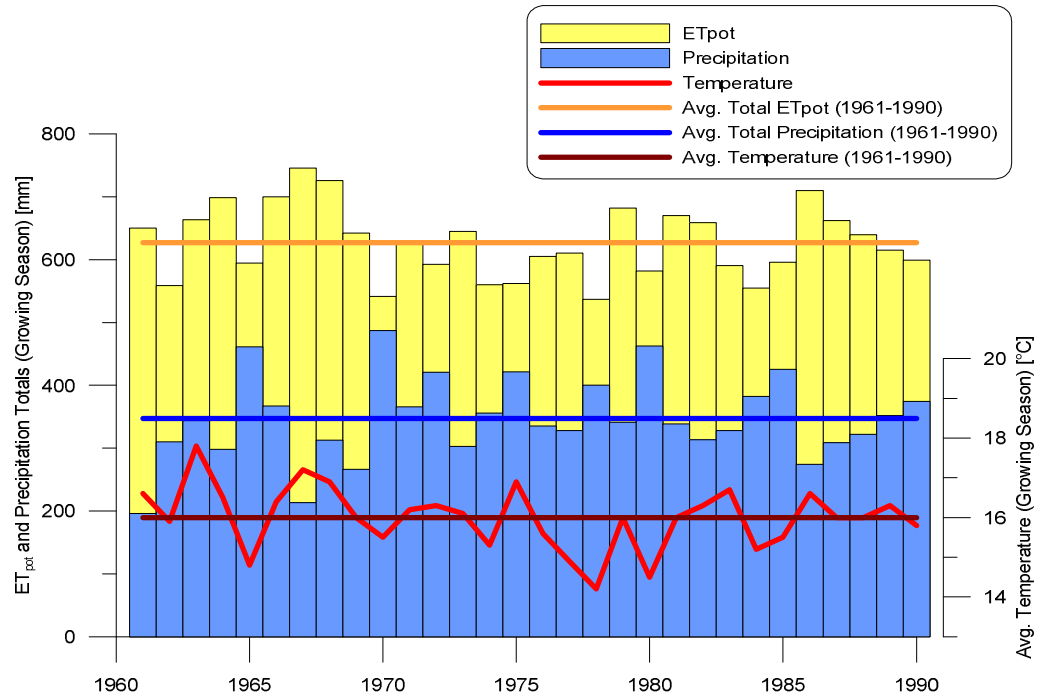

Figure 1. Growing seasons totals of selected meteorological elements from 1961 to 1990

A brief statistical survey from Fig 1 gives Tab 1.

Table 1. Basic statistics from selected meteorological elements

\begin{tabular}{|l|c|c|c|c|}
\hline & $\begin{array}{c}\mathrm{ET}_{\text {pot }} \\
(\text { Totals for GS }) \\
{[\mathrm{mm}]}\end{array}$ & $\begin{array}{c}\mathrm{ET}_{\text {pot }} \\
(\text { Avg. for GS }) \\
{[\mathrm{mm}]}\end{array}$ & $\begin{array}{c}\text { Temperature } \\
(\text { Avg. for GS }) \\
{\left[{ }^{\circ} \mathrm{C}\right]}\end{array}$ & $\begin{array}{c}\text { Precipitation } \\
(\text { Totals for GS }) \\
{[\mathrm{mm}]}\end{array}$ \\
\hline \hline Min. & $537(1978)$ & $2.93(1978)$ & $14.2(1978)$ & $196(1961)$ \\
\hline Max. & $746(1967)$ & $4.08(1967)$ & $17.8(1963)$ & $487(1970)$ \\
\hline Avg. & 627 & 3.43 & 16.0 & 347 \\
\hline Median & 620 & 3.39 & 16.0 & 340 \\
\hline Year 1971 & 625 & 3.42 & 16.2 & 366 \\
\hline
\end{tabular}

Representative GS in 1971 was recalculated with CCCM 2000 scenario for 2010, 2030 and 2075. Outputs were in form of daily values of $\mathrm{ET}_{\mathrm{pot}}$ and precipitation.

Tab 2 gives short survey of $\mathrm{ET}_{\text {pot }}$ and precipitation after application of CCCM 2000 scenario. As shown in Tab 2, scenario CCCM 2000 predicts progressive raise of $\mathrm{ET}_{\text {pot }}$ and slightly decrease of precipitation values in future GS. 
Table 2. ET and Precipitaion

\begin{tabular}{|c|c|c|}
\hline & $\begin{array}{c}\text { ET }_{\text {pot }} \text { (Totals for GS) } \\
{[\mathrm{mm}]}\end{array}$ & $\begin{array}{c}\text { Precipitation (Totals for GS) } \\
{[\mathrm{mm}]}\end{array}$ \\
\hline \hline 1971 & 625 & 366 \\
\hline $2010($ CCCM 2000$)$ & $689(+10 \%)$ & $363(-1 \%)$ \\
\hline $2030($ CCCM 2000$)$ & $716(+15 \%)$ & $351(-4 \%)$ \\
\hline $2075($ CCCM 2000$)$ & $793(+27 \%)$ & $359(-2 \%)$ \\
\hline
\end{tabular}

Detailed forecast of $\mathrm{ET}_{\text {pot }}$ daily values is presented in Fig 2.

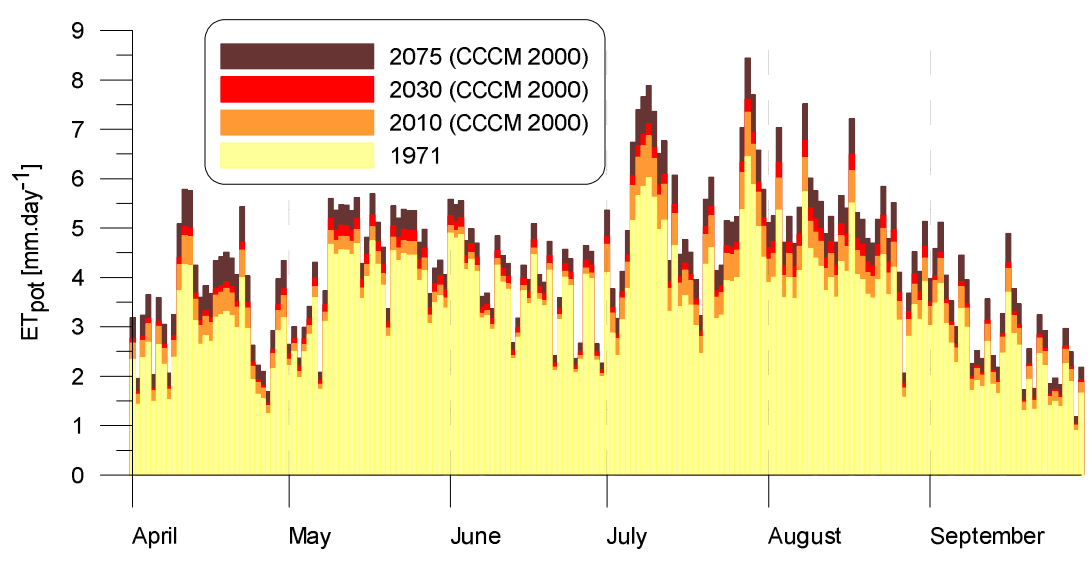

Figure 2. Daily $\mathrm{ET}_{\text {pot }}$ values according the CCCM 2000 climatic scenario

Outputs from CCCM 2000 were used as a inputs for numerical simulation of GWL. Computed courses of GWL are presented in Fig 3.

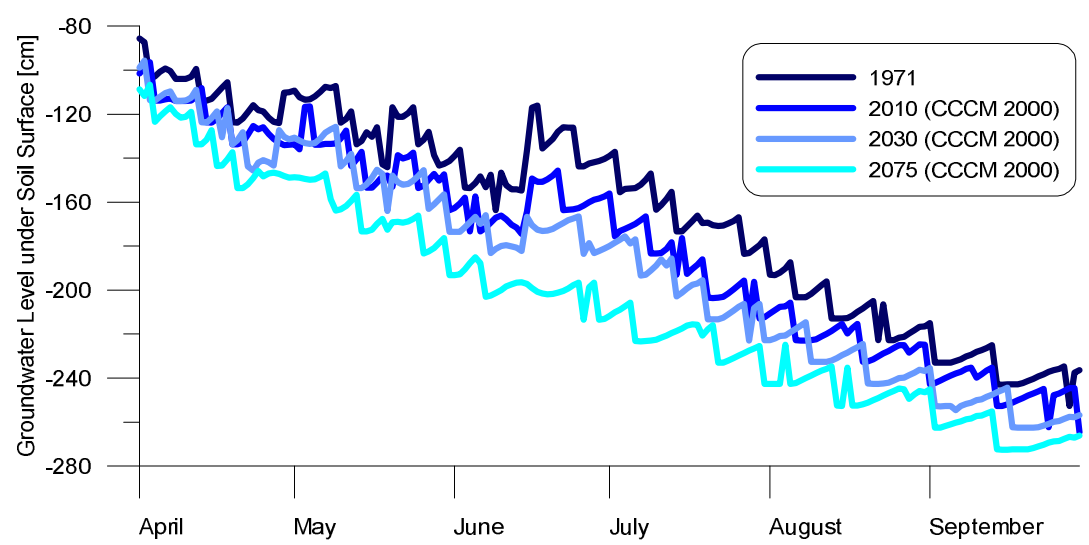

Figure 3. Modeled courses of GWL according the CCCM 2000 climatic scenario 
As shown in Fig 3, the trends of GWL in future years will be decreasing. An average level of GWL during GS in reference year 1971 was located $1.64 \mathrm{~m}$ under surface. Simulated GWL level in 2010 is $1.80 \mathrm{~m}$ under surface (decrease of 10\%). In future years the GWL will decrease according to the model to $1.88 \mathrm{~m}(-15 \%)$ in 2030 and to $2.05 \mathrm{~m}(-25 \%)$ in 2075.

\section{Conclusions}

Obtained were outputs from climatic scenario CCCM 2000 in form of daily sums of $\mathrm{ET}_{\text {pot }}$ and precipitations for locality Milhostov in East Slovakian Lowland. These values were used in mathematical model FLOCR for the purpose of prognosis of groundwater levels courses. Modeled outputs confirmed excepted decreasing trend of groundwater level in the future, which is probably caused by climatic changes. An average GWL level during growing season in representative year 1971 was $1.64 \mathrm{~m}$ under surface. As a result of predicted climatic changes, the GWL level in 2010 can decrease about $0.16 \mathrm{~m}$ $(-10 \%)$, in 2030 about $0.24 \mathrm{~m}(-15 \%)$ and in 2075 about $0.41 \mathrm{~m}(-25 \%)$. These changes can be evaluated as an unwelcome especially for agricultural sphere.

\section{Acknowledgements}

The author would like thank for the kind support of the project VEGA 2/0130/09.

\section{References}

Gomboš, M. - Pavelková, D. - Mati, R.: 2007. Časové a priestorové hodnotenie priemerných ročných úrovní hladiny podzemnej vody v Medzibodroží. Acta Hydrologica Slovaca. 8: 1. 127-134.

Kandra, B. - Gomboš, M.: 2008. Influence of climatic elements on the water regime in a soil profile. Cereal Research Communications, 36: 1187-1190.

Lapin, M. - Hlavčová, K. - Petrovič, P.: 2003. Vplyv klimatickej zmeny na hydrologické procesy. Acta Hydrologica Slovaca, 4: 2. 211 - 221

Nagy, V. - Štekauerová, V. - Neményi, M. - Milics, G. - Koltai, G.: 2007. The role of soil moisture regime in sustainable agriculture in both side of river Danube in 2002 and 2003. Cereal Research Communications, 35: 2. 821-824.

Oostindie, K. - Bronswijk, J. J. B.: 1992. FLOCR - A simulation model for the calculation of water balance, cracking and surface subsidence of clay soils : Report 47. Wageningen : The Winand Staring Centre for Integrated Land, Soil and Water Research. 65

Šoltész, A. - Baroková, D. - Hašková, L.: 2007. Optimalizácia vodného režimu na Medzibodroží. Acta Hydrologica Slovaca. 8: 2. 173-181. 


\title{
INDEX OF RELATIVE CROP AREA COVERAGE AND ITS RELATION TO NITRATE LOAD IN AGRICULTURAL SURFACE STREAM
}

\author{
Pavla PEKAROVA ${ }^{1}$ - Dana HALMOVA ${ }^{l}$ - Pavol MIKLANEK ${ }^{1}$ - Jan PEKAR ${ }^{2}$ \\ Ivan MESZAROS ${ }^{1}$ \\ ${ }^{1}$ Institute of Hydrology SAS, Bratislava, Racianska 75, Slovakia, e-mail: pekarova@uh.savba.sk \\ ${ }^{2}$ Faculty of Mathematics, Physics and Informatics, Comenius University, Bratislava, Slovakia
}

Abstract: The major objective of this paper is to show how land cover and land use affect the inorganic nitrogen export budget in two neighboring experimental microbasins differing in land cover. The aim of first part of the study is the comparison of the transported loads of nitrates from the agricultural microbasin Rybarik and the forested microbasin Lesny - located in the Puchov highland (West Slovakia). In the second part, the relative crop area coverage index $(R C I)$ is defined and quantified in the agricultural microbasin Rybarik. The use of RCI proved to be the proper tool for crop categorization according their ability to cover the soil surface. In the long-term period the impact of crop on nitrate load in the surface water was demonstrated. The nitrate load was 1.4-2.0 times higher in average in the years with maize growing compared to the period of barley-winter wheat growing.

Keywords: nitrate load, stream water, experimental basins

\section{Introduction}

The problems of nitrogen species contribution to the stream water quality in agricultural basins or nutrient loading changes in an agricultural watershed and its effects on water quality and stream biota are widely studied over the world (Heathewaite and Johnes, 1996; Chambers et al., 2006; Veliskova et al., 2009 Kadar, 2009). The transport of inorganic and organic forms of nitrogen from the soil, surface- and groundwater to surface streams is affected by agricultural activities (Haggard et al., 2003). Each watershed has its own intrinsic properties affecting the chemical composition of soil and surface water. Experimental basins received a great deal of popularity in hydrological and other environmentally oriented disciplines. Studying forested and agricultural landscapes can help understand the factors responsible for an excessive export of nutrients from headwater areas. It has been shown that the type of vegetation, age, and stand structure can actively affect the content of solutes in stream water (Siwek el al., 2008).

\section{Materials and methods}

Established in 1958 by the Institute of Hydrology, SAS, the experimental basin of the Mostenik creek $\left(18^{\circ} 40^{\prime} \mathrm{E}, 49^{\circ} \mathrm{N}\right)$ was one of the first hydrologic experimental sites in Slovakia (Figure 1).

Figure 1. Scheme of the experimental microbasins: Rybarik (agricultural), and Lesny (forested)

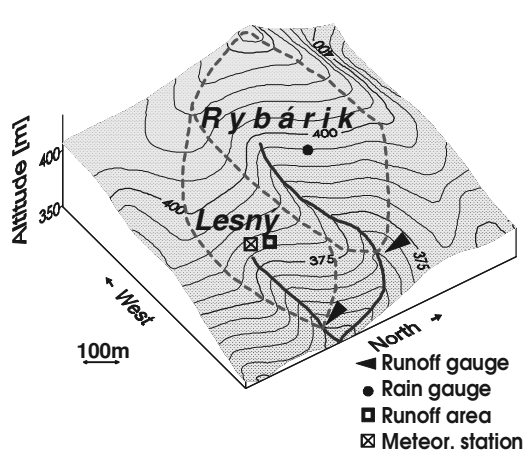

DOI: 10.1556/Novenyterm.59.2010.Suppl.3 
The surface area of the experimental forested subbasin Lesny is $0.0864 \mathrm{~km}^{2}$. The length of the stream to closing profile is $214 \mathrm{~m}$, soil class is brown forest soil. Basin has $90 \%$ of forest with following species: $75 \%$ hornbeam, $20 \%$ spruce, $5 \%$ pine. The age of the forest in 2005 was approximately $70-75$ years, stand density 0.86 .

Total area of the agricultural subbasin Rybarik is $0.119 \mathrm{~km}^{2}$. The length of the stream from spring to closing profile is $256 \mathrm{~m}$, the mean slope of the stream is $9.1 \%$, and the mean slope of the basin is $14.9 \%$. The basin is $70 \%$ cultivated by the state farm; private farmer covers the rest of the area.

In the Rybarik as well as in the Lesny microbasins, stream runoff were measured by the Thomson weirs, and recorded continuously by limnigraphs. Development of the basic hydrological balance elements is shown in graphs of the Figure 2. Since 1987, stream water samples were taken in 1-3 day intervals, depending on the runoff change. Approximately 100 samples per year were taken from both localities (Pekarova et al. 2009).

\section{Results and discussion}

The observed $\mathrm{NO}_{3}{ }^{-}$concentrations were used for calculation of the annual total nitrate loads $\left(\mathrm{LNO}_{3}{ }^{-}\right)$transported by surface runoff from the microbasins Rybarik and Lesny during the hydrological years 1986/87-2005/06. The annual nitrate loads from Rybarik microbasin show a decreasing trend with minor oscillations in certain years.
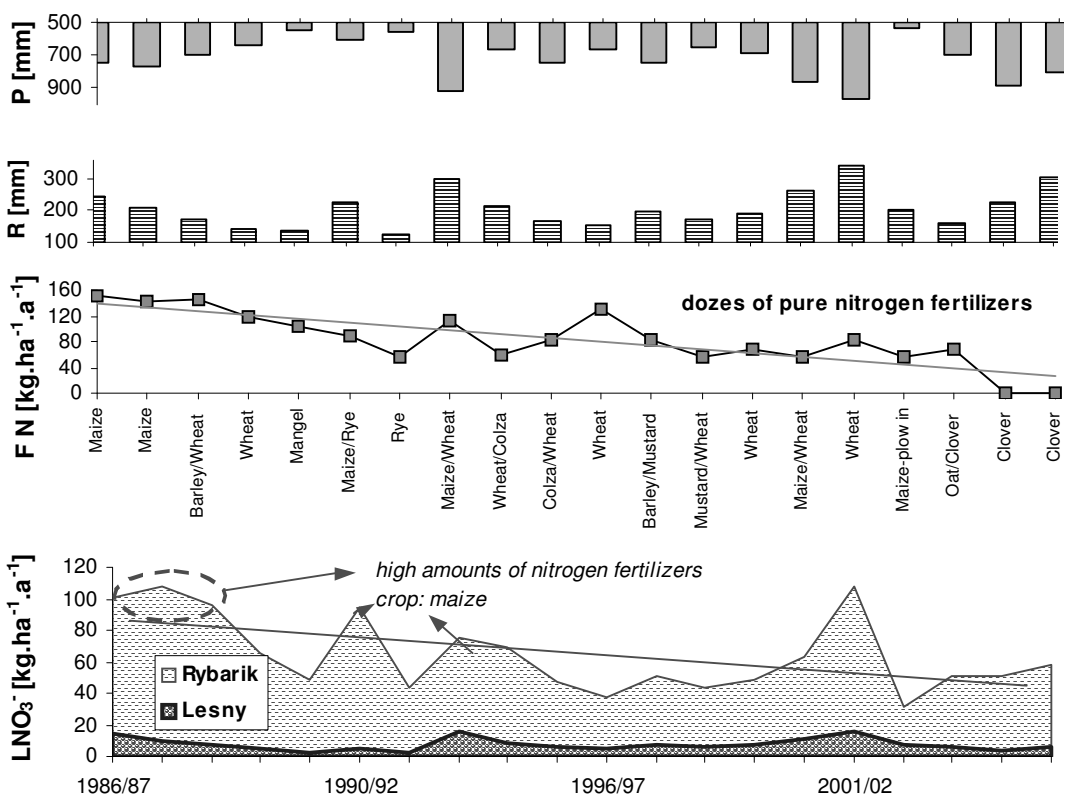

Figure 2. Mean annual precipitation totals $\mathrm{P}$, runoff R, dozes of nitrogen fertilizers $\mathrm{F}$ and the exported loads of nitrates $\mathrm{LNO}_{3}{ }^{-}$from the microbasins Rybarik and Lesny, 1986/87-2006/06 period 


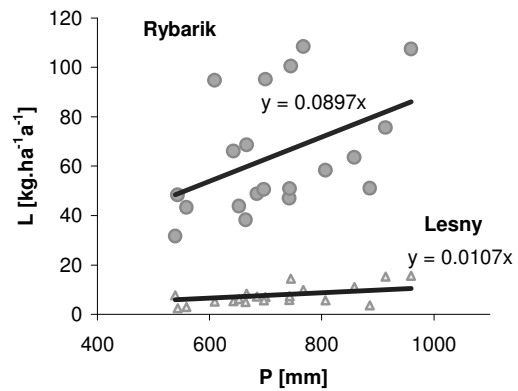

a)

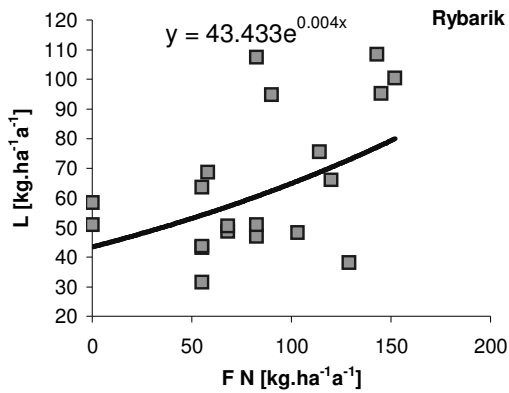

b)

Figure 3. a) Impact of the annual precipitation totals $\mathrm{P}$ upon the nitrate loads $\mathrm{L}$ transported from the Rybarik microbasin in the stream. b) Relationship between the annual applied pure nitrogen fertilizers FN and the nitrate loads L exported by stream from the Rybarik microbasin, period 1986/87-2005/06

These are caused by higher rainfall and higher runoff in certain years (Figure 3a), higher amounts of applied nitrogen fertilizers (Figure 3b), grown crops or combination of the mentioned factors. The yearly nitrate loads transported from the agricultural microbasin Rybarik varied from 31 to $108.5 \mathrm{~kg} \cdot \mathrm{ha}^{-1} \cdot \mathrm{a}^{-1}$, in the average of $65 \mathrm{~kg} \cdot \mathrm{ha}^{-1} \cdot \mathrm{a}^{-1}$. The yearly nitrate loads transported from the Lesny forested microbasin were within the range of 2.5 and $15.5 \mathrm{~kg} \cdot \mathrm{ha}^{-1} \cdot \mathrm{a}^{-1}$, the mean loads value was $7.6 \mathrm{~kg} \cdot \mathrm{ha}^{-1} \cdot \mathrm{a}^{-1}$.

In the second part of the study, we quantified impacts of the individual growled plant species in the agricultural microbasin Rybarik upon the basin runoff process and the nitrates intrusion through the soil profile into the basin runoff (expressed by the nitrate loads). From the database we selected data on the vegetation height $h(\mathrm{~cm})$ in the Rybarik microbasin, defined as mean height of the plants on the monitored area, and was registered in the biweekly intervals. From the plants height monthly values $h_{\text {month }}$, we calculated monthly values of the relative soil vegetation coverage index $R C I_{\text {month }}$ for the of the 20 years 1986/87-2005/06 period, according to formulae:

$R C I_{\text {month }}=h_{\text {month }} / h_{\text {max }}$,

where: $h_{\max }$ - is the maximum achieved vegetation height $(\mathrm{cm})$.

The yearly soil vegetation coverage index $R C I$ was determined as arithmetic mean of its monthly values.

The proposed parameter $R C I$ should not be confused and identified with the frequently used in professional literature the soil surface coverage parameter $s p$ (ratio of the vegetation covered area to the total area of the areal unit, in vertical projection). It should also not be confused with the leaf area index $L A I$. The long-term yearly course of the vegetation coverage index $R C I$ and of the nitrates concentration in the Rybarik stream, is presented in the Figure 4a. Impact of the $R C I$ index and the planted vegetation species can be seen on Figure 4b. The nitrate load was 1.4-2.0 times higher in average in the years with maize growing compared to the period of barley wheat growing. 


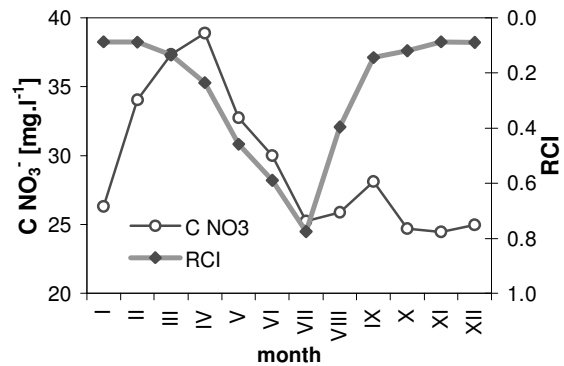

a)

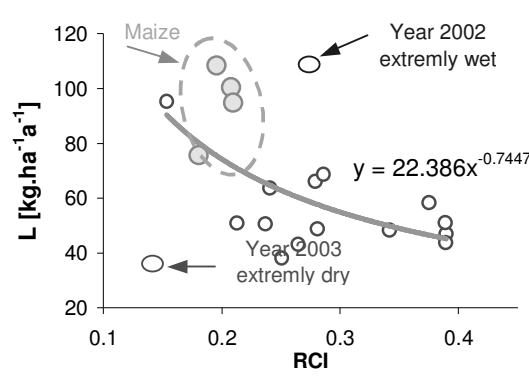

b)

Figure 4. a) Long-term annual course of the soil vegetation coverage index RCI and the nitrate concentrations, Rybarik microbasin. b) Dependence of the yearly nitrate transport upon the yearly course of the soil vegetation coverage index RCI, basin Rybarik, period 1986/87-2005/06.

\section{Conclusions}

The mean annual nitrate load from the agricultural microbasin Rybarik is 8.5-times higher than that from the forested microbasin Lesny during the period 1987-2006.

In accordance with the European Water Directive (WFD 2000), EU states are under the obligation to evaluate water quality in rivers according to watercourse type. The WFD defined a new term - the reference basin - designed to establish limits of what can be classified as "good water conditions". The Lesny microbasin can be used as "reference basins" for a given type of watercourse in the Slovakia.

\section{Acknowledgement}

This study was supported by Science and Technology Agency (Slovakia) under contract No. APVT 443/0 and by the project VEGA 0096/08.

\section{References}

Chambers P. A. - Meissner R. - Wrona F. J. - Rupp H. - Guhr, H. - Seeger J. - Culp J. M. - Brua R. B.: 2006. Changes in nutrient loading in an agricultural watershed and its effects on water quality and stream biota. Hydrobiologia, 556: 399-415.

Haggard B. E. - Moore P. A. - Chaubey I. - Stanley E. H.: 2003. Nitrogen and Phosphorus Concentrations and Export from an Ozark Plateau Catchment in the United States. Biosystems Engineering, 86: 75-85.

Heathwaite A. L. - Johnes P. J.: 1996. Contribution of nitrogen species and phosphorus fractions to stream water quality in agricultural basins. Hydrological Processes, 10: 7, 971-983.

Kadar I.: 2009. The effect of fertilisation on spring barley on calcareous sandy soil. Novenyterm, 58: 1, 5163.

Pekarova P. - Miklanek P. - Onderka M. - Kohnova S.: 2009. Water balance comparison of two small experimental basins with different vegetation cover. Biologia, 64: 3, 487-491.

Siwek J.P. - Żelazny M. - Chełmicki W.: 2008. Annual changes in the chemical composition of stream water in small catchments with different land-use (Carpathian Foothills, Poland). Soil and Water Research, 3: 3 $129-137$.

Veliskova Y. - Dulovicova R. - Skalova J.: 2009. Quality and quantity of water resources as stress factor for agri-environment at eastern part of Rye Island (Slovakia). Cereal Res. Comm., 37, 493-496. 


\title{
INFLUENCE OF GROUND WATER LEVEL ON THE WATER SUPPLY OF PLANTS ON SOILS WITH VARIOUS HYDROPHYSICAL CHARACTERISTICS
}

\author{
DANA PAVELKOVÁ
}

Institute of Hydrology, Slovak Academy of Sciences, Hollého 42, 07101 Michalovce, Slovakia

e-mail: pavelkova@uh.savba.sk

\begin{abstract}
Location of groundwater level and its dynamics in lowland areas is a result of meteorological conditions and hydrophysical characteristics of the soil profile. The meteorological elements are characterized by high temporal and spatial variability. Temporal variability of hydrophysical properties is negligible in comparison to meteorological elements. Spatial variability of hydrophysical properties is copying the areal variability of soil types.

In this paper are calculated functionalities between the positions of groundwater level and water supplies in the root zone of plant cover for selected soil types, using numerical simulation. There were identified threshold limits of the level of the groundwater level at which is the water supply in the root zone of the soil profile independent from the groundwater level position. Moreover, the example of extremely dry year 2007 documented the regulatory effects of groundwater level, which is defined for the threshold limits on the water supply in the root zone of plant cover.
\end{abstract}

Keywords: water availability, soil characteristics, ground water level, water supply

\section{Introduction}

Groundwater is part of the system of atmosphere - plant cover - unsaturated zone groundwater. Ground water level (GWL) defines the unsaturated zone in the space and time at its bottom. Position of GWL affects a water supply (WS) in soils and water availability for plant cover. Water storage in soil aeration zone represents an accessible water source for agricultural and forest ecosystems.

Relation between GWL and water supply in soil was a subject mater of many works. (Gomboš, 2008; Kandra et al., 2009; Kotorová and Mati, 2008; Šoltész and Baroková, 2006; Štekauerová et al., 2009; Tall, 2007; Várallyay and Rajkai, 1989).

The aim of this paper is to quantify the influence of GWL position to water supply in the root zone of plants in different soil types and to identify threshold limits of GWL, by which the water supply is at the level of threshold point.

\section{Materials and methods}

Influence of GWL position on water supply has been analyzed in the area of Medzibodrožie, in its Slovak part. It is the southernmost and the lowest elevated place of East Slovakian Lowland (ESL). It is situated in the south-east part of the Slovak Republic. Surface area of Medzibodrožie is $370 \mathrm{~km}^{2}$. The influence of position of GWL on the water supply was evaluated in four soil types. These were in light soils, medially heavy soils, heavy soils and extreme heavy soils. To examine this issue, the numerical simulation on a mathematical model GLOBAL was used (Majerčák and Novák, 1994).

The mathematical model GLOBAL was verified by the monitoring results of soil moisture in the studied area during the vegetation period in 2007. Analyzed profile in the numerical simulation was selected to the depth of $4 \mathrm{~m}$ below the surface. Water 
supply in the soil affected by the position of GWL has been evaluated to the depth of 1 $\mathrm{m}$ below the surface.

Numerical simulation was carried out with daily step. Hydrometeorological conditions entering into the mathematical model and the variability of GWL were used from the vegetation season in 2007.

Dependence of water supply from the position of GWL under the surface was expressed graphically for monitored soil types. Based on the obtained dependencies it was able to identify threshold limits of position of GWL. These are the limit points of position of GWL, by which the water supply is at the level of threshold point under the hydrophysical and hydrometeorological conditions. Consecutively, there was documented the regulatory effect of GWL, which was identified for threshold limits on water supply in the root zone of soil profile to the depth of 1 meter by use of the numerical simulation. Quantification of this influence is illustrated on medially heavy soils in the area of Somotor during the vegetation season in 2007.

\section{Results and discussion}

The Figure 1 shows the monitored dependence of GWL on the water supply in the root zone for different soil types. In 2007, GWL ranged from 3.5 to $2 \mathrm{~m}$ in monitored profiles. The figure shows the result that the heavier the soil is, the lower position beginning of the influence of GWL on water supply in the root zone of soil profile. In terms of retention, the influence of GWL is stronger in heavy soils with high content of clay elements. There was also analyzed course of dependence curves. The detailed analysis of the waveform shows that the beginning of non-linear course appears when the average of GWL at a distance of $3 \sigma(\sigma-$ standard deviation of the vertical movement of GWL) is below the bottom border of evaluated soil layer. At the distance of $2 \sigma$ the course of lines of dependences significantly changes and this indicates intense influence of GWL on the water supply in the monitored layer. It follows that the level of GWL increasingly encroaches into the soil profile. If the average position of the GWL under the balance layer of soil is $2 \sigma$, then in case of Gaussian random variable (position of GWL) $4.5 \%$ of positions of GWL above its average value directly affects the balance layer of soil. As an average value of GWL approaches to the bottom border of evaluated soil layer, the influence of GWL to the water storage is increasing.

From the course of given dependencies threshold limits on the levels of GWL were identified. That is defined as the average position of GWL at which the water supply of balanced layer of soil oscillates around threshold point (TP) under the given hydrophysical conditions.

From the above graph (Fig.1) it results that in case of light soil the water supply to the depth of $1 \mathrm{~m}$ at the TP is $227 \mathrm{~mm}$. To this moisture condition corresponds the threshold limit level of GWL $1.53 \mathrm{~m}$ below the surface. This level of GWL is below the bottom border of evaluated soil layer at a distance of size $1 \sigma$. For the medially heavy soils (TP $=265 \mathrm{~mm}$ ), the threshold value of GWL is located at a depth of 1.77 meters below the surface. GWL is then at a level below the $\sigma$ or $2 \sigma$ bottom border of evaluated soil layer lowered for. For the heavy soils $(\mathrm{TP}=304 \mathrm{~mm}) \mathrm{GWL}$ is located at a depth of 1.84 meters below the surface. As well in this case, the location of GWL is below the $\sigma$ or 
$2 \sigma$ bottom border of evaluated soil layer lowered for. For the very heavy soils $(\mathrm{TP}=373$ $\mathrm{mm}$ ) it is located at a depth of 2.28 meters below the surface. GWL is then at a level between $2 \sigma$ and $3 \sigma$.

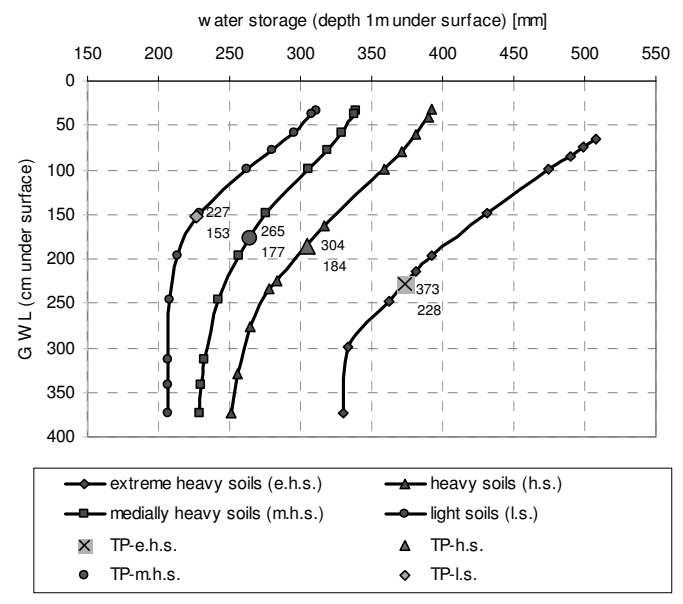

Figure 1. Influence of position of GWL to the WS in the root zone to the depth of $1 \mathrm{~m}$ for different soil types

In Fig. 2 there are documented the regulatory effects of GWL on the medially heavy soils in the Somotor locality, during the vegetation season in 2007. Regulated level of GWL is defined to the identified threshold level. From Fig.2 results that at the current state of GWL the water supply in the root zone is below the level of TP during the whole vegetation season. After increasing the level of GWL to the threshold limit of $177 \mathrm{~cm}$ below the terrain, the calculated water supply in the root zone oscillates around the level of TP. This illustrates the impact of regulation of GWL on water supply in the soil.

\section{Conclusions}

The aim of this paper is to quantify the influence of the position of GWL on water supply in the root zone of plants in different soil types and to identify the threshold limits of the level of GWL. This influence has been studied by numerical simulation on the mathematical model GLOBAL. The threshold limits of GWL are defined as level of GWL at which the water supply is at the TP under the given hydrophysical conditions. The research has shown that the influence of GWL on the water supply in the balance layer of soil profile depends on its variability and median value of its position in relation to the bottom border of evaluated soil layer. Influence of GWL on the water supply in the balance layer starts to show more if median position of GWL is below $2 \sigma$ the bottom border of evaluated layer of soil profile. It is well established on the regulatory effect of GWL defined for the threshold limits at which the water supply oscillates around TP. 


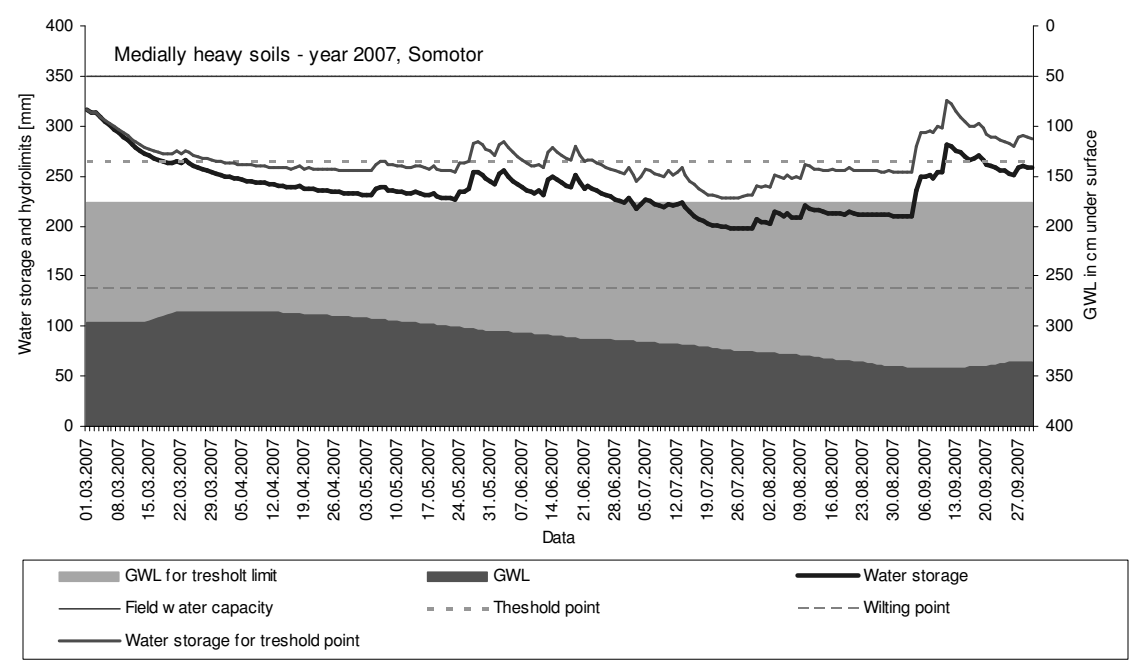

Figure 2. The regulatory effects of groundwater level, which is defined for the threshold limits on the water supply in the root zone.

\section{Acknowledgements}

The author would like to thank for the kind support of the project VEGA 2/0130/09.

\section{References}

Gomboš M.: 2008. Water storage dependability in root zone of soil. In Cereal Research Communications. 36, 1, 1191-1194. (1.190 - IF2008).

Kandra B. - Gomboš M. - Šútor J.: 2009. Kvantifikácia tokov vody medzi zónou aerácie pôdy a hladinou podzemnej vody. In Acta Hydrologica Slovaca. 10: 1. 84-93.

Kotorová D. - Mati R.: 2008. The trend analyse of water storage and physical properties in profile of heavy soils. In: Agriculture (Pol'nohospodárstvo) 54, 2008, č. 4, s. 155-164. ISSN 0551-3677

Majerčák J. - Novák V.: 1994. GLOBAL - a numerical model for water movement in the soil root zone. Research Report, IH-SAS, Bratislava, 75

Šoltész A. - Baroková D.: 2006. Analysis, prognosis and design of control measures of Ground water level regime using numerical modelling, Podzemná voda, XII, SAH, Bratislava 2006, č.2, s.113-123

Štekauerová V. - Nagy V. - Š́tor J. - Milics G. - Neményi M.: 2009. Influence of groundwater level on soil water regime of Žitný ostrov. In V. Növénytermesztési Tudományos Nap - Növénytermesztés: Gazdálkodás - Klimaváltozás - Társadalom. 197-200. ISBN 978-963-05-8804-1.

Tall A.: 2007. Impact of canopy on the water storage dynamics in soil. In Cereal Research Communications. 35. 2. 1185-1188.

Várallyay Gy. - Rajkai, K.,: 1989. Model for the estimation of water (and solute) transport from the groundwater to overlying soil horizons. In. Hung. Agrokémia és Talajtan. 38. 641-656. 


\title{
INFLUENCE OF HYDROAMELIORATED SOIL ON CHLORTOLURON LEACHING AND YIELD OF WINTER WHEAT
}

\author{
Ivan SIMUNIC ${ }^{1}$ - Mario SRAKA ${ }^{2}-$ Tanja LIKSO ${ }^{3}-$ Vilim FILIPOVIC $^{1}-$ \\ Stipo BELJAN ${ }^{4}$ \\ ${ }^{1}$ Faculty of Agriculture, University of Zagreb, Department of Soil Amelioration, Svetosimunska 25, 10000 \\ Zagreb, Croatia, e-mail: simunic@agr.hr \\ ${ }^{2}$ Faculty of Agriculture, University of Zagreb, Department of Soil Science, Svetosimunska 25, 10000 Zagreb, \\ Croatia \\ ${ }^{3}$ Meteorological and Hydrological Service of Croatia, Gric 3, 10000 Zagreb, Croatia \\ ${ }^{4}$ Student of postgraduate study
}

\begin{abstract}
Winter wheat is the leading culture according to sow area in Croatia. Herbicide products based on chlortoluron are most widely used because of their inhibition of photosynthesis that provides pre- and postemergence control of many annual and perennial weeds. Therefore the aim of this study was to determine the concentration and leaching of chlortoluron in drainage water on pipe drainage spacing from $20 \mathrm{~m}$. The study was conducted on reclamation test field, on hydroameliorated Gleyic Podzoluvisol during three years. Chlortoluron extracted from the samples of drainage waters was determinated by gas chromatography. Data were statistically processed by means of analysis of variance. The concentration of the chlortoluron recorded in drainage waters varied in a wide range, with maximum values recorded soon after its application and at the start of higher drainage discharge. The results indicate that maximal concentration of chlortoluron in drainage water exceeded the maximum allowable concentration (MAC) for single herbicides in drinking water (100 ng $\mathrm{I}^{-1}$ ) in the larger part of the year and there were statistically significant differences between the quantity of chlortoluron leached in tested years, as well as quantity of yield winter wheat in tested years. There are very high coefficient of correlation between the sum of annual precipitation and drainage discharge $(\mathrm{r}=0.981)$, as well as drainage discharge and leached of chlortoluron $(\mathrm{r}=0.977)$.
\end{abstract}

Keywords: hydroameliorated soil, chlortoluron leaching, winter wheat yield

\section{Introduction}

Application of herbicides to arable lands is one of the most important practices for controlling weed growth in modern agriculture. However, intensive use of pesticides in conventional agricultural practices has resulted in continuous and serious environmental (soil, water, food and organisms) pollution (Jolánkai et al., 2006; Kirsch et al., 2007; Varga et al., 2007; Velisková, 2006; Simunic et al., 2008). Since the winter wheat is the leading culture according to sow area in Croatia, herbicide products based on chlorotoluron are most widely used and one of the most frequently found in our water resources.

Chlorotoluron [3-(3-chloro-4-methylphenyl)-1, 1-dimethylurea], a phenylurea herbicide, with high activity and relatively low toxicity, is widely used for controlling grass weeds during the crop production. Recent studies have shown that due to its moderate adsorption onto soil constituents, chlorotoluron is fairly mobile and leaching, that can be detected in agricultural soils, lakes, streams and rivers (Denser, 2000).

The aim of the research carried out during 1997/98, 2000/01, 2006/07 was:

- to determine the concentration and leaching of chlortoluron in drainage waters on pipe drainage spacing from $20 \mathrm{~m}$; 
- to determine, whether there is a statistical significant, difference in concentration of chlortoluron in drainage water and its leaching between different tested years, and in yield of winter wheat between tested years.

\section{Materials and methods}

Trials were carried out on the Jelenscak reclamation test field, on hydroameliorated Gleyic Podzolluvisol during three years, which is located in the Sava river valley. Trial variant involved a drainpipe spacing from $20 \mathrm{~m}$, set up in four replications, which were combined with gravel as contact material $(\varnothing 5-25 \mathrm{~mm})$ in the drainage ditch above the pipe. Drainpipe characteristics were: length $95 \mathrm{~m}$, diameter $65 \mathrm{~mm}$, average slope 3\%o and average depth $1 \mathrm{~m}$. Drainpipes discharged directly into open canals. Each replication covered area of $1900 \mathrm{~m}^{2}$. Winter wheat was grown as the trial crop and the same agricultural practices were applied in all trial years. Weed control involved application of herbicide Dicuran forte (1.6 kgha-1, based on active substance chlortoluron $79.25 \%$ ), soon after sowing. Drainage discharge was measured continually by means of automatic electronic gauges - limnimeters. Drainage water was sampled every day during the discharge period. Chlortoluron extracted from the samples of drainage waters was detected by gas chromatography. The detection limit for chlortoluron in drainage waters was $20 \mathrm{ng} \mathrm{l}^{-1}$, well below the legal European limit for individual pesticides in drinking water (the EC maximum admissible concentration, 100 $\mathrm{ng}^{-1}$ ). Total annual quantities of chlortoluron leached were estimated on the basis of average monthly concentration and monthly quantity of drainage discharge. Data were statistically processed by means of the ANOVA.

\section{Results and discussion}

To facilitate interpretation of research results, the factors of soil and precipitation were taken into consideration (Table 1. and 2.), as well as hydrological relations (Table 3.).

Table 1. Major properties of drained Gleyic Podzoluvisol

\begin{tabular}{|c|c|c|c|c|c|c|c|c|c|c|}
\hline \multirow[t]{2}{*}{ Profile } & \multirow[t]{2}{*}{$\begin{array}{l}\text { Depth, } \\
\mathrm{cm}\end{array}$} & \multicolumn{2}{|c|}{$\begin{array}{c}\text { Content of } \\
\text { particles, } \\
\%\end{array}$} & \multirow[t]{2}{*}{$\begin{array}{c}\text { Porosity, } \\
\% \text { vol. }\end{array}$} & \multicolumn{2}{|c|}{$\begin{array}{c}\text { Capacity } \\
\text { for, \% vol. }\end{array}$} & \multirow[t]{2}{*}{$\begin{array}{l}\text { Permea- } \\
\text { bility, } \\
\text { m day }^{-1}\end{array}$} & \multirow[t]{2}{*}{$\begin{array}{c}\text { Bulk } \\
\text { density, } \\
\mathrm{g} \mathrm{cm}^{-1}\end{array}$} & \multirow[t]{2}{*}{$\begin{array}{c}\mathrm{pH} \\
\mathrm{KCl}\end{array}$} & \multirow[t]{2}{*}{$\begin{array}{c}\text { Organic } \\
\text { mater, } \\
\%\end{array}$} \\
\hline & & Silt & Clay & & Water & Air & & & & \\
\hline Ap & $0-35$ & 47 & 46 & 48 & 44 & 4 & "0,011 & 1,35 & 5,8 & 3,0 \\
\hline Btg & $35-75$ & 45 & 48 & 49 & 45 & 4 & 0,010 & 1,41 & 5,5 & \\
\hline Gso & $75-115$ & 55 & 39 & 46 & 42 & 4 & 0,011 & 1,43 & 7,1 & \\
\hline $\mathrm{Gr}$ & $115-130$ & 63 & 25 & 49 & 45 & 4 & & & & \\
\hline
\end{tabular}

Table 2. Total monthly and annual precipitation and its mean values, $1 \mathrm{~m}^{-2}$

\begin{tabular}{|c|c|c|c|c|c|c|c|c|c|c|c|c|c|}
\hline Year & X & XI & XII & I & II & III & IV & V & VI & VII & VIII & IX & $\Sigma$ \\
\hline \hline $1997 / 98$ & 76 & 127 & 86 & 65 & 5 & 58 & 59 & 103 & 107 & 121 & 87 & 174 & 1068 \\
\hline $2000 / 01$ & 49 & 96 & 79 & 88 & 4 & 102 & 60 & 35 & 121 & 35 & 44 & 197 & 910 \\
\hline $2006 / 07$ & 27 & 86 & 28 & 82 & 58 & 85 & 7 & 92 & 43 & 27 & 55 & 141 & 731 \\
\hline
\end{tabular}

Drainage discharge is important indicator of pipe drainage efficiency in draining excess water from soil. It can be seen (Table 3) that there were differences in the quantity of drainage discharge between the trial years, which are caused primarily because of different total annual quantity and distribution of precipitation. There are very high coefficient of correlation between the sum of annual precipitation and drainage discharge $(\mathrm{r}=0.981)$, as well as drainage discharge and leached of chlortoluron $(\mathrm{r}=0.977)$. 
Table 3. Quantities of drainage discharge $\left(1 \mathrm{~m}^{-2}\right)$

\begin{tabular}{|c|c|c|c|c|c|c|c|c|c|c|c|c|c|}
\hline Year & X & XI & XII & I & II & III & IV & V & VI & VII & VIII & IX & $\Sigma$ \\
\hline \hline $1997 / 98$ & 0 & 23 & 34 & 36 & 5 & 29 & 21 & 19 & 23 & 0 & 0 & 37 & 227 \\
\hline $2000 / 01$ & 0 & 0 & 61 & 31 & 0 & 37 & 30 & 0 & 6 & 0 & 0 & 45 & 210 \\
\hline $2006 / 07$ & 0 & 23 & 18 & 38 & 25 & 31 & 0 & 0 & 0 & 0 & 0 & 35 & 170 \\
\hline
\end{tabular}

It can be seen from Table 4. that different maximum and average values were determined for chlortoluron concentrations in drainage water in trial years. This was influenced by the date of chlortoluron application, quantity and distribution of rainfall and the quantity of drainage discharge. Similar results for concentrations of chlortoluron in drainage water for drainpipe spacing of $20 \mathrm{~m}$ were obtained Sraka et al. (2007).

Table 4. Minimum, maximum and average concentrations of chlortoluron (ng $\left.{ }^{-1}\right)$ in drainage water

\begin{tabular}{|c|c|c|c|c|c|c|c|c|c|}
\hline \multirow{2}{*}{ Spacing variants (m) } & \multicolumn{3}{|c|}{$1997 / 98$} & \multicolumn{3}{c|}{$2000 / 01$} & \multicolumn{3}{|c|}{$2006 / 07$} \\
\cline { 2 - 10 } & Min & Max & X & Min & Max & X & Min & Max & X \\
\hline 20 & $<20$ & 389 & 277 & $<20$ & 390 & 219 & $<20$ & 365 & 267 \\
\hline
\end{tabular}

Maximum chlortoluron concentrations in drainage water were recorded soon after its application and at the start of higher drainage discharge; they decreased in all years with later drainage discharge (figure 1).

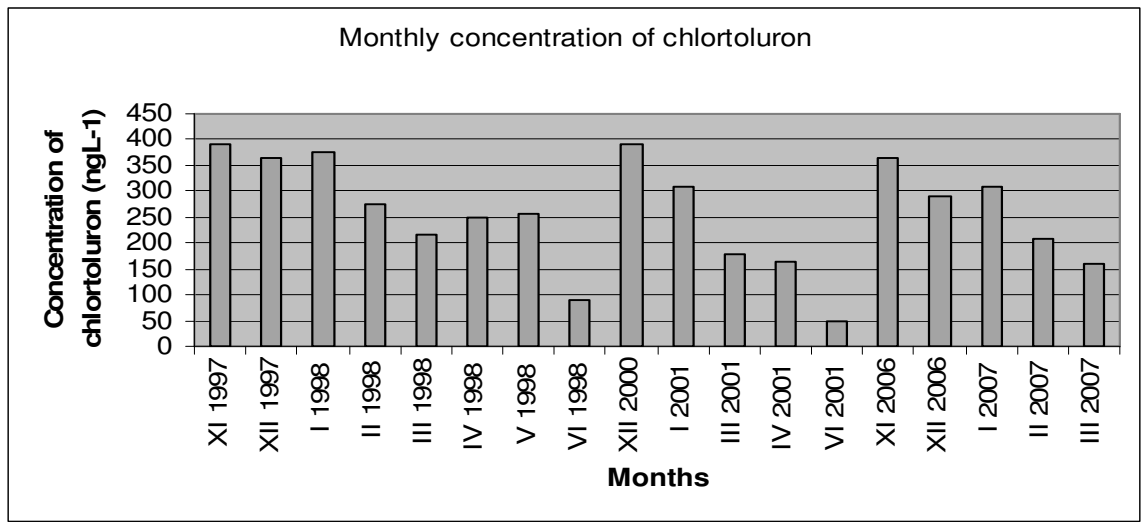

Figure 1. Fluctutation of chlortoluron concentration $\left(\mathrm{ng}^{1-1}\right)$ in drainage water

Results on the contamination of drainage water with chlortoluron are in agreement with the results Accinelli et al. (2002). This authors point to the fact that the quantity of pesticides leached in these parts is strongly influenced by the distribution of precipitation (drainage discharge), time of herbicide application, their quantities added, and the phenological stage of winter wheat. Larger quantity of total chlortoluron leached was recorded in the first two years (higher total drainage discharge and higher concentrations), table 5. Chlortoluron losses ranged from $43 \%$ to $28 . \%$ and were statistically significant difference in quantity of chlortoluron leached beetwen tested years (table 5). 
Table 5. Duncan's multiple range test for the mean values of quantity chlortoluron leached $\left(\mathrm{g} \mathrm{ha}^{-1}\right)$ during examined years

\begin{tabular}{|c|c|c|c|}
\hline Years & g ha $^{-1}$ & $\%$ & Group \\
\hline \hline $1997 / 98$ & 546 & 43,1 & ac \\
\hline $2000 / 01$ & 454 & 35,7 & ab \\
\hline $2006 / 07$ & 357 & 28,1 & bc \\
\hline
\end{tabular}

Values that are not marked by the same letter are significantly different.

The highest yields were archived in first years of investigation (1997/98) and the lowest yields are archived in last years of investigation (2006/2007), table 6. Statistically significant difference in yields between particular years can been probably due to various factors, like climatic factors, guantity of drainage discharge and chlortoluron leached, as well as chlorotoluron accumulation in plants. Namely, Song et al. (2007) indicate that the accumulation of chlorotoluron by plants affected the plant growth and caused the metabolic disorder.

Table 6. Duncan's multiple range test for the mean values of winter wheat yields $\left(\mathrm{t} \mathrm{ha}^{-1}\right)$ during examinedyears

\begin{tabular}{|c|c|c|}
\hline Years & $\mathrm{t} \mathrm{ha}^{-1}$ & Group \\
\hline \hline $1997 / 98$ & 3.89 & $\mathrm{ab}$ \\
\hline $2000 / 01$ & 3.75 & $\mathrm{ac}$ \\
\hline $2006 / 07$ & 3.36 & $\mathrm{cb}$ \\
\hline
\end{tabular}

Values that are not marked by the same letter are significantly different.

\section{Conclusions}

In 7-8 months in all years concentrations of chlortoluron were higher from the tolerated limit $\left(100 \mathrm{ng} \mathrm{l}^{-1}\right)$. Quantity of chlortoluron leached is depended on the total drainage discharge and its concentrations in drainage water. ANOVA showed that there were statistically significant differences both between the quantities of chlortoluron leached and achieved yields in all the years of research.

\section{References}

Accineli C. - Vicari A. - Rossi P. - Catizone P.: 2002. Losses of atrazine, metolachlor, prosulfuron and triasulfuron in subsurface drain water. Agronomie 22: 399- 411.

Denser J.W.: 2000. Toxicity of mixtures of pesticides in aquatic systems. Pest Management Science 56: 516520.

Jolánkai M. - Szentpétery Z. - Hegedűs Z.: 2006. Pesticide residue discharge dynamics in wheat grain. Cereal Research Communications 34: 1. 505- 508.

Kirsch J. - Horváth E. - Vágvölgyi C. - Tanács L.: 2007. Mobility of herbicides and fungicides in soil and their effects on soil microorganisms. Cereal Research Communications 35: 1. 673- 676.

Simunic I. - Sraka M. - Husnjak S. - Tomic F. - Baric K.: 2008. Influence of drainpipe on atrazine leaching. Cereal Research Communications, 36: (Suppl.). 1143- 1146.

Song N.H. - Yin X.L. - Chen F.G. - Yang H.: 2007. Biological responses of wheat (Triticum aestivum) plants to the herbicide chlorotoluron in soils. Chemosphere 68: 9. 1779- 1787.

Sraka M. - Vidacek Z. - Smit Z. - Bensa A. - Vrhovec D.: 2007. Herbicides in the soil and waters of river Drava catchment area. Cereal Research Communications 35: 2. 1089-1 092.

Varga B. - Svecnjak Z. - Jurkovic Z. - Pospisil M.: 2007. Quality responses of winter wheat cultivars to nitrogen and fungicide applications in Croatia. Acta Agronomica Hungarica 55: 1. 37- 48.

Vargha M. - Somlai Z. - Takáts Z. - Márialigeti K.: 2004. Microbiological impact of atrazine pollution in river sediment and soil. Acta Agronomica Hungarica 52: 3. 297- 307.

Velisková Y.: 2006. Problem of water pollution and ways of solution. Cereal Research Communications 34:1. 101- 103. 


\title{
IRRIGATION, NITROGEN FERTILIZATION AND GENOTYPE IMPACTS ON YIELD AND QUALITY OF MAIZE GRAIN
}

\author{
Marko JOSIPOVIĆ ${ }^{l}$ - Hrvoje PLAVŠIĆ ${ }^{1}$ - Ivan BRKIĆ ${ }^{l}$ - Rezica SUDAR ${ }^{l}$ \\ Monika MARKOVIĆ ${ }^{2}$ \\ ${ }^{1}$ Department of Agricultural Technics and Melioration, Agricultural Institute Osijek, Južno predgrađe 17 \\ Osijek 31 000; e-mail: markoj@poljinos.hr \\ 2 Department of Plant Production, Faculty of Agriculture, University J.J. Strossmayer, Osijek, Croatia
}

\begin{abstract}
Influences of irrigation rates $(A 1=$ non-irrigated, A2 $=$ irrigation starting on level of $60 \%$ field water capacity or FWC; A3 = irrigation starting on level of $80 \%$ FWC), nitrogen $(\mathrm{N})$ fertilization $(0,100$ and $200 \mathrm{~kg} \mathrm{~N} \mathrm{ha}^{-1}$, for the B1, B2 and B3, respectively) and genotype (maize hybrids: OSSK 596, OSK 602, OSSK 617 and OSSK 552) on yield and protein content in maize grain were tested under field conditions on Osijek eutric cambisol during four growing seasons (2006-2009). In general (4-year means comparison), irrigation and nitrogen fertilization resulted by maize yield increases up to $15 \%$ ( 8880 and $10198 \mathrm{~kg} \mathrm{ha}^{-1}$, for A1 and A3, respectively) and up to $19 \%$ ( 8700 and $10347 \mathrm{~kg} \mathrm{ha}^{-1}$, for 0 and $200 \mathrm{~kg} \mathrm{~N} \mathrm{ha}^{-1}$, respectively), while differences of yields among the hybrids were in range from $9259 \mathrm{~kg} \mathrm{ha}^{-1}$ (OSSK 596) to $9814 \mathrm{~kg} \mathrm{ha}^{-1}$ (OSSK $602)$. Also, protein contents in maize grain were slight decreased by irrigation $(8.81 \%$ and $8.51 \%$ for $\mathrm{A} 1$ and A3, respectively) and increased by $\mathrm{N}$ fertilization $\left(8.28 \%\right.$ and $8.92 \%$, for 0 and $200 \mathrm{~kg} \mathrm{~N} \mathrm{ha}^{-1}$, respectively), while differences of protein contents among the maize hybrids were in range from $8.51 \%$ (OSSK 552 ) to $8.79 \%$ (OSSK 617). Depending on the year, effects of irrigation on maize yield increases were from $13 \%$ (2006, 2008 and 2009) to $28 \%$ (2007). N fertilization effects on yield increases were the lowest in $2007(+13$ $\%$ ) while in the remaining three years they were higher and reciprocally similar (from $20 \%$ to $22 \%$ ).
\end{abstract}

Keywords: irrigation of maize, nitrogen fertilization, protein content

\section{Introduction}

Average cropped area (trough years 1988 to 2008) by maize (Zea mays L.) in Croatia is 358700 ha with average yield $5.66 \mathrm{t} \mathrm{ha}^{-1}$ (Croatian Statistic Bureau, 2009). Hot weather and limited precipitation during the growing season may alter protein, oil and starch concentrations in grain. Jurgens et al. (1978) found that drought increased the protein concentration, but decreased oil concentration. Irrigation consistently affected grain yield across the years and protein content in dry year according to Josipović et al. (2007), also. Maize is relatively tolerant to water stress during the vegetative stage, very sensitive during tasseling, silking and pollination and moderately sensitive during grain filling (Shaw, 1988). Thus, supplemental irrigation during critical stages of flowering and grain filling should eventually facilitate better grain quality. The objective of this study is show influence of irrigation, nitrogen $(\mathrm{N})$ fertilization and genotype on yield and protein concentration in maize grain.

\section{Materials and methods}

Influences of irrigation rates (IR), nitrogen (N) fertilization and genotype on yield and protein content in maize grain were tested under field conditions on Osijek $\left(45^{\circ} 32^{\prime \prime} \mathrm{N}\right.$ and $18^{\circ} 44^{\prime \prime} \mathrm{E}$; $90 \mathrm{~m}$ above sea level) during the four growing seasons (2006-2009). Irrigation (the factor $\mathrm{A}$ ) treatments were as follows: $\mathrm{A} 1=$ non-irrigated, $\mathrm{A} 2$ = irrigation starting on level of $60 \%$ field water capacity (FWC); A3 = irrigation starting on level of $80 \%$ (FWC) - Table 1. Self-moving sprinkler performed irrigation. Increased rates of N 
fertilization (the sub-factor B) were added: 0,100 and $200 \mathrm{~kg} \mathrm{~N} \mathrm{ha}^{-1}$, for the B1, B2 and $\mathrm{B} 3$, respectively. Two third of planned $\mathrm{N}$ quantities were added in autumn and before sowing (urea: $46 \% \mathrm{~N}$ ) and the rest by two top-dressings at early growth stages (calcium ammonium nitrate: $27 \% \mathrm{~N})$. Phosphorus $\left(100 \mathrm{~kg} \mathrm{P}_{2} \mathrm{O}_{5} \mathrm{ha}^{-1}\right)$ and potassium $\left(150 \mathrm{~kg} \mathrm{ha}^{-1}\right.$ $\left.\mathrm{K}_{2} \mathrm{O}\right)$ were applied in form of triplesuperphosphate $\left(45 \% \mathrm{P}_{2} \mathrm{O}_{5}\right)$ and potassium salt $(60 \%$ $\mathrm{K}_{2} \mathrm{O}$ as $\mathrm{KCl}$ ). Four maize cultivars (sub-sub factor $\mathrm{C}$ : $\mathrm{C} 1=$ OSSK 596, C2 = OSSK 602, C3 = OSSK 617 and C4 = OSSK 552) were tested. The experiment was conducted by split-split plot method according to randomized block design. Area of basic experimental plots were $19.6 \mathrm{~m}^{2}$ (genotype), $78.4 \mathrm{~m}^{2}$ (nitrogen) and $235 \mathrm{~m}^{2}$ (irrigation), respectively. Soil type is eutric cambisol (Soil Survey Division Staff, 1993), silt clay loam texture, shallow gley, $\mathrm{pH}$ in $\mathrm{KCl}$ from 6.5 to $6.9, \mathrm{P}_{2} \mathrm{O}_{5}$ content is from 22.6 to 26.4 $\mathrm{mg}$ per 100 grams of soil, $\mathrm{K}_{2} \mathrm{O}$ content is from 30.4 to $36.5 \mathrm{mg}$ per 100 grams of soil. Maize was sown in the middle of April and harvested in the first half of October. Planned plant density was 58309 plants ha ${ }^{-1}$ (spacing between rows $70 \mathrm{~cm}$ and distance in the row $24.5 \mathrm{~cm}$ ). Grain yields calculated on $13 \%$ grain moisture basis. Protein content was measured by NIT technology (Infratecc 1241, Foss Tecator). The statistics of trial's data results performed according SAS GLM, split-plot model procedure (SAS, 1998). The soil had retention water capacity close the value of FWC. Low precipitation and high air-temperatures characterized the 2007 and 2009 growing seasons (Table 2). Rainfall shortage, especially during July and August is mainly in close connection with low yields of spring crops including maize (Kovačević and Josipović, 2001).

Table 1 . Water distribution by irrigation and precipitation

\begin{tabular}{|c|c|c|c|c|c|c|c|}
\hline \multirow{3}{*}{ Year } & \multicolumn{4}{|c|}{ Number of irrigations (n) and irrigated water (mm) } & \multicolumn{3}{|c|}{ Water supply $(\mathrm{mm})$} \\
\hline & \multicolumn{2}{|c|}{$\mathrm{A} 2$} & \multicolumn{2}{|c|}{ A3 } & $\mathrm{A} 1 *$ & $\mathrm{~A} 2$ & $\mathrm{~A} 3$ \\
\hline & $\mathrm{n}$ & $\mathrm{mm}$ & $\mathrm{n}$ & $\mathrm{mm}$ & \multicolumn{3}{|c|}{$*=$ dry farming - precipitation only } \\
\hline 2006 & 2 & 80 & $\overline{3}$ & 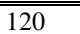 & $\overline{4413.9}$ & 493.9 & 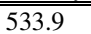 \\
\hline 2007 & 3 & 120 & 5 & 200 & 301.7 & 421.7 & 501.7 \\
\hline 2008 & 2 & 80 & 3 & 120 & 437.3 & 517.3 & 557.3 \\
\hline 2009 & 4 & 200 & 6 & 240 & 230.8 & 430.8 & 470.8 \\
\hline Mean & 2.8 & 120 & 4.3 & 170 & 345.9 & 465.9 & 515.9 \\
\hline
\end{tabular}

Table 2. Mean air temperature and precipitation (Osijek Weather Bureau)

\begin{tabular}{|c|c|c|c|c|c|c|c|c|c|c|}
\hline \multicolumn{11}{|c|}{ Mean air-temperature and precipitation in Osijek for 2006-2009 period $(61-90=$ mean 1961-1990) } \\
\hline & \multicolumn{5}{|c|}{ Mean air-temperature $\left({ }^{\circ} \mathrm{C}\right)$} & \multicolumn{5}{|c|}{ Precipitation $(\mathrm{mm})$} \\
\hline & 2006 & 2007 & 2008 & 2009 & $61-90$ & 2006 & 2007 & 2008 & 2009 & $61-90$ \\
\hline April & 12.9 & 13.7 & 12.6 & 14.6 & 11.3 & 95.5 & 0.7 & 51.6 & 15.7 & 54.1 \\
\hline May & 17.0 & 19.0 & 19.3 & 19.0 & 16.5 & 79.3 & 48.5 & 114.5 & 45.5 & 58.9 \\
\hline June & 20.5 & 22.7 & 22.0 & 19.7 & 19.4 & 52.5 & 80.6 & 88.9 & 73.9 & 83.5 \\
\hline July & 24.8 & 24.8 & 22.8 & 23.6 & 21.1 & 15.3 & 31.7 & 70.1 & 31.0 & 66.6 \\
\hline August & 20.5 & 23.5 & 23.1 & 23.5 & 20.3 & 122.6 & 89.0 & 27.8 & 61.9 & 59.6 \\
\hline September & 17.9 & 14.8 & 15.9 & 19.6 & 16.6 & 8.7 & 71.2 & 85.4 & 2.8 & 51.8 \\
\hline & 18.9 & 19.7 & 19.3 & 20.0 & 17.5 & 413.9 & 301.7 & 437.3 & 230.8 & 368.3 \\
\hline
\end{tabular}




\section{Results and discussion}

Impacts of irrigation, $\mathrm{N}$ fertilization and genotype on maize yield and protein contents in grain were shown in the Table 3. In general (4-year means comparison), irrigation and nitrogen fertilization resulted by maize yield increases up to $15 \%$ (8880 and 10198 $\mathrm{kg} \mathrm{ha}^{-1}$, for A1 and A3, respectively) and up to $19 \%$ (8700 and $10347 \mathrm{~kg} \mathrm{ha}^{-1}$, for 0 and $200 \mathrm{~kg} \mathrm{~N} \mathrm{ha}^{-1}$, respectively), while differences of yields among the hybrids increases up to $6 \%$ (from $9259 \mathrm{~kg} \mathrm{ha}^{-1}$, OSSK 596 to $9814 \mathrm{~kg} \mathrm{ha}^{-1}$, OSSK 602). Irrigation, as main factor, $\mathrm{N}$ fertilization as sub factor and maize as sub-sub factor resulted by statistically high significant differences $(\mathrm{P} \geq 0.01)$ in all investigated years in maize grain yield. Those results were in accordance with Russelle et al. (1981). Depending on the year, effects of irrigation on maize yield increases were from $13 \%(2006,2008$ and 2009) to $28 \%$ (2007). N fertilization effects were the lowest in $2007(+13 \%)$ while in the remaining three years they were higher and reciprocally similar (from $20 \%$ to $22 \%$ ).

Table 3. Influences of irrigation, $\mathrm{N}$ fertilization and genotype on yield and protein content in grain of maize

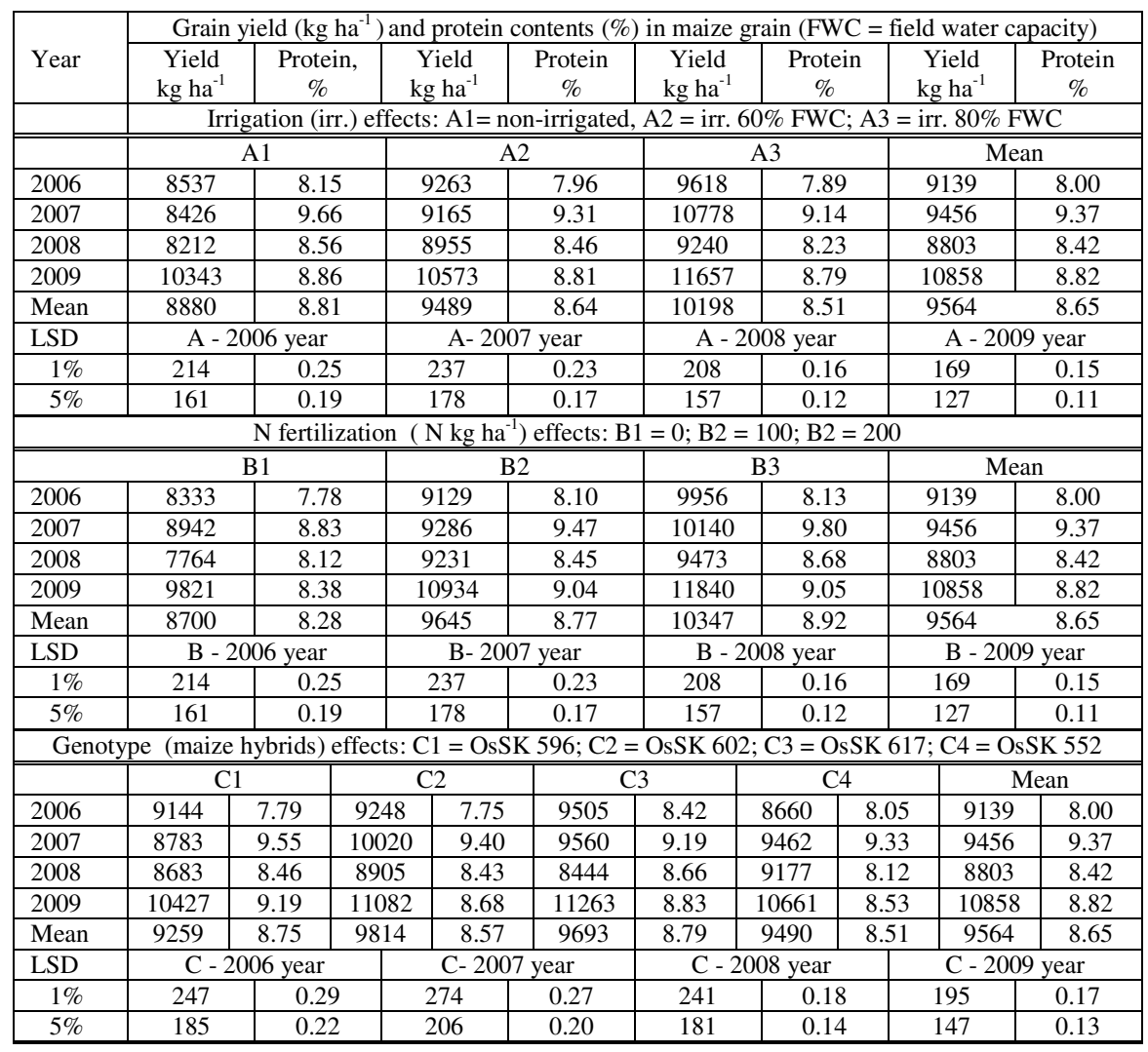


Also, protein contents in maize grain were slight decreased by irrigation $(8.81 \%$ and $8.51 \%$ for $\mathrm{A} 1$ and $\mathrm{A} 3$, respectively) and increased by $\mathrm{N}$ fertilization $(8.28 \%$ and $8.92 \%$, for 0 and $200 \mathrm{~kg} \mathrm{~N} \mathrm{ha}^{-1}$, respectively). Differences of protein contents among the maize hybrids were in range from $8.51 \%$ (OSSK 552) to $8.79 \%$ (OSSK 617) what corresponds with Jurgens et al. (1978) and Josipović et al. (2007) findings. Also, irrigation had significant effect $(\mathrm{P} \geq 0.05)$ in three investigated years on protein concentration, thus both irrigation treatments (A2 and A3) decreased the protein concentration opposite control treatment. Both, nitrogen fertilization and maize hybrids resulted by high significant level $(\mathrm{P} \geq 0.01)$ effect on protein concentration in all investigated years. Statistical significant combination treatments of maize grain yields were: $A B, A C$ and $\mathrm{ABC}$ in all investigated years, while in protein concentration treatments, $\mathrm{AB}$ were in three years, BC, AC combinations treatments in two years, respectively.

\section{Conclusions}

Irrigation and nitrogen fertilization resulted in maize yield increases up to $28 \%$ and up to $22 \%$, while differences of yields among the hybrids were up to $11 \%$. Also, protein contents in maize grain were slightly decreased by irrigation and increased by $\mathrm{N}$ fertilization, while differences of protein contents among the maize hybrids were also recorded. Irrigation from $80 \%$ to $100 \%$ FWC and $200 \mathrm{~kg}$ of N ha ${ }^{-1}$ with OSSK 602 and OSSK 613 hybrids could ensure high yields, while protein content might be decreased by irrigation, but increased by $\mathrm{N}$ fertilization and OSSK 613 hybrid the protein content.

\section{References}

Croatian Statistical Bureau.: 2009. www.hzs.hr

Josipović, M. - Jambrović, A. - Plavšić, H. - Liović, I. - Šoštarić, J.: 2007. Responses of grain composition traits to high plant density in irrigated maize hybrids. Cereal Research Communications, 35: 549-552.

Jurgens, S.K. - Johnson, R.R. - Boyer, J.S.: 1978. Dry matter production and translocation in maize subjected to drought during grain fill. Agronomy Journal 70:678-682.

Kovacevic V. - Josipovic M.: 2001. Soil degradation and weather influences on corn yields in eastern Croatia. 3rd International Conference on Land Degradation, Sept, 2001, Rio de Janeiro, Brazil. 130.

Meteorological and Hydrological Bulletin: 2006, 2007, 2008, 2009. Meteorological and Hydrological Bulletin Service of Republic of Croatia. http://meteo.hr

Russelle, M.P. - Diebert, E.J. - Hauch, R.D. - Stevanovic, M. - Olson, R.A.: 1981. Effects of water and nitrogen management on yield and ${ }^{15} \mathrm{~N}$-depletes fertilizer use effciciency of irrigated corn. Soil Science of America Journal 45 (3): 553-558.

SAS: 1998. SAS Online doc V7. SAS Institute Inc., Cary, NC.

Shaw, R.H.: 1988. Climate requirement. In: Sprague G.F., Dudley J.W., (eds.) Corn and Corn Improvement. 609-638. Agr. Mon. 18. $3^{\text {rd }}$ ed. Madison,WI: ASA, CSSA and SSSA.

Soil Survey Division Staff: 1993. Soil survey manual. Soil Conservation Service. U.S. Department of Agriculture Handbook 18. 


\title{
MODELLING EFFECTS OF IRRIGATION ON NITROGEN BALANCE AND MAIZE YIELD IN DIFFERENT TILLAGE SYSTEMS
}

\author{
Attila MEGYES
}

Institute for Land Utilisation, Technology and Regional Development, Centre for Agricultural Sciences and Engineering, University of Debrecen, H-4032 Debrecen Böszörményi u. 138., megyesat@agr.unideb.hu

\begin{abstract}
The objective of this study was to evaluate the effects of irrigation and tillage, under fertilized and non-fertilized conditions in eastern Hungary, on nitrogen balance and maize yield over the 2004-2006 crop seasons. The investigated tillage treatments were winter ploughing (WP) and disk tillage (DT). 4M crop simulation model was used for simulation. Under the very wet weather conditions over the 2004-2006 crop seasons, maize yield was significantly decreased by irrigation especially in non-fertilized plots, depending on tillage method (0,4 to 2,3 $\left.\mathrm{t} \mathrm{ha}^{-1}\right)$. The extent of yield drop was lower on fertilized plots and even a slight yield surplus was observed in the case of WP $\left(0.5-0.6 \mathrm{t} \mathrm{ha}^{-1}\right)$ - with the exception of 2005. Based on the simulation model runs, it was established that around $300-354 \mathrm{~kg} \mathrm{ha}^{-1}$ mineral $\mathrm{N}$ left the system on non-fertilized plots without irrigation during three years, depending on the tillage method applied, whereas $\mathrm{N}$ loss was moderate on well fertilized plots (149-191 kg ha $\left.{ }^{-1}\right)$. The decrease of the total soil $\mathrm{N}$ was slight in DT on both fertilized and non-fertilized plots. Estimated nitrogen leaching was greater in WP, while higher denitrification was predicted in DT. Fertilization and irrigation has increased nitrogen leaching as well as denitrification. Model' predicting in some cases results over-estimating.
\end{abstract}

Keywords: irrigation, tillage, simulation model, nitrogen-balance, nitrogen leaching

\section{Introduction}

There are crop years, when natural precipitation covers the water need of maize hybrids and the precipitation in the growing season significantly exceeding the average level. Under that conditions over-irrigation causes yield depression, it can reduce yield under the potential level by leaching nutrients out of the soil, causing airless conditions and increasing liability to diseases (Lelkes, 2001). Research results also show that yield decrease can occur as a result of irrigation in certain crop years in areas with inadequate nutrient supply, therefore the harmony of nutrient and water supply has to be provided simultaneously (Nagy, 2008). Work has been carried out in the last few years to study the soil water and nitrogen regime under different tillage methods in eastern Hungary and their influence on the development of field crops (Huzsvai et al., 2005).

The objective of this study was to evaluate the effects of irrigation and tillage, under fertilized and non-fertilized conditions in eastern Hungary, on nitrogen balance and maize yield over the 2004-2006 crop seasons.

\section{Materials and methods}

This study was conducted in 2004-2006 at the Látókép Experimental Station of the Centre of Agricultural Sciences and Engineering, Debrecen University located in the north-eastern part of the Great Hungarian Plain (47 $30^{\prime} \mathrm{N}, 21^{\circ} 36^{\prime} \mathrm{E}, 121 \mathrm{~m}$ elevation). The soil of the experimental site was a lowland pseudomyceliar chernozem (MollisolCalciustoll or Vermustoll, silt loam). The investigations were part of a long-term field experiment. The investigated tillage treatments were winter ploughing (WP) to a depth of $27 \mathrm{~cm}$ and disk tillage (DT) to a depth of $12 \mathrm{~cm}$. In autumn, $\mathrm{N}$ fertilizer was applied at a rate of 0 and $120 \mathrm{~kg} \mathrm{ha}^{-1}$. Corn hybrids (LG 2305 [FAO 290] in 2004, Goldaccord 
[FAO 310] in 2005 and 2006) were sown at a rate of 50,000 germs ha ${ }^{-1}$. Valmont linear irrigation system was used on the experimental plots. The amount of irrigation water was $100 \mathrm{~mm}$ in 2004, $80 \mathrm{~mm}$ in 2005 and $90 \mathrm{~mm}$ in 2006, respectively. The weather condition in the period of 2004-2006 was very favorable for maize, with sufficient precipitation both in the winter and in the vegetation period.

$4 \mathrm{M}$ v. 4.5 software package was used for modeling cropping systems (Fodor et al., 2002). The $4 \mathrm{M}$ crop model is a daily-step, deterministic model that simulates the water and nutrient balance of the soil, the soil-plant interactions and the plant development and growth. The validation of the model was done years ago, the data base required for executing the model is constantly updated. The model was continuously run from Oct 192003 to Oct 202006 covering the crop seasons of 2004, 2005 and 2006.

\section{Results and discussion}

When examining the $\mathrm{N}$ cycle of long-term field experiments, several problems might arise during the preparation of $\mathrm{N}$ balances that could be avoided by simulation models. By using simulation models, we can accurately estimate the nitrogen conversion and transport processes $\left(\mathrm{NO}_{3}\right.$ mineralization, leaching and denitrification) that are difficult or expensive to determine during traditional field examinations.

Based on the simulation model runs, it was established that around 300-354 kg ha ${ }^{-1}$ mineral $\mathrm{N}$ left the system on non-fertilized plots without irrigation during three years, depending on the tillage method applied, whereas $\mathrm{N}$ loss was moderate on well fertilized plots $\left(149-191 \mathrm{~kg} \mathrm{ha}^{-1}\right)$. This $\mathrm{N}$ is originated from $\mathrm{N}$ uptake from soil by maize, $\mathrm{N}$ leaching and denitrification as well. The decrease of the total soil $\mathrm{N}$ was slight in the DT treatment on both fertilized and non-fertilized plots. The model estimated an $\mathrm{N}$ balance which was $18-28 \%$ more negative at the end of the running period when WP was applied, depending on the fertilization method.

Based on the results of the runs provided by the model, the extent of cumulative $\mathrm{NO}_{3}$ leaching is negligible under non-irrigated conditions, whereas it increased 2-2.5 times as a result of fertilization. The extent of leaching was higher in the WP treatment than in DT. On the contrary, the extent of estimated denitrification was higher in DT and it further increased as a result of fertilization. This phenomenon can be explained by the unfavorable, insufficient water supply of the compacted layer of the soil at $15-20 \mathrm{~cm}$ depth, as well as the prevalence of reductive processes which are typical of anaerobic soil layers.

The simulation analyses show that besides fertilization, irrigation further increased both $\mathrm{NO}_{3}$ leaching and the denitrification of nitrogen. The increased leaching caused by irrigation was also observed in the WP treatment, whereas denitrification was more expressed in DT. The examinations show that $100-120 \mathrm{~kg} \mathrm{ha}^{-1} \mathrm{~N}$ is leached out of the upper $100 \mathrm{~cm}$ of the fertilized soils during 3 years, depending on the tillage method and the extent of irrigation. This value equals to an average yearly fertilizer dose used in the experiment. Nevertheless, this amount cannot be totally considered to be a loss, as maize can utilize the amount of plant available soil $\mathrm{N}$ of the $100-200 \mathrm{~cm}$ soil profile, even if only to a smaller extent (Table 1-2).

The results of the model runs are also confirmed by the smaller mineral $\mathrm{N}$ content measured in the soil profiles of the irrigated area, which indicates an intensive leaching to deeper layers. 
Table 1. Nitrogen balance of WP treatment in the upper $100 \mathrm{~cm}$ soil profile $\left(\mathrm{N} \mathrm{kg} \mathrm{ha}^{-1}\right)$.

\begin{tabular}{|c|c|c|c|c|c|c|}
\hline & \multicolumn{3}{|c|}{ Non-irrigated } & \multicolumn{3}{|c|}{ Irrigated } \\
\hline & Initial & & Final & Initial & & Final \\
\hline & Oct 192003 & Balance & Oct 202006 & Oct 192003 & Balance & Oct 202006 \\
\hline $\mathrm{Nokg} \mathrm{ha}{ }^{-1}$ & & & & & & \\
\hline Soil Organic N & 29803 & & 29455 & 29803 & & 29475 \\
\hline Initial Residue N & 40 & & 52 & 37 & & 44 \\
\hline Soil $\mathrm{NO}_{3}$ & 67 & & 50 & 62 & & 34 \\
\hline Soil $\mathrm{NH}_{4}$ & 7 & & 6 & 7 & & 6 \\
\hline Leached $\mathrm{NO}_{3}$ & & -45 & & & -72 & \\
\hline N Denitrified & & -9 & & & -19 & \\
\hline Fertilizer N & & 0 & & & 0 & \\
\hline Organic residue & & 160 & & & 139 & \\
\hline N Uptake from Soil & & -460 & & & -398 & \\
\hline Total N & 29917 & -354 & 29563 & 29909 & -350 & 29559 \\
\hline $\mathrm{N} 120 \mathrm{~kg} \mathrm{ha}^{-1}$ & & & & & & \\
\hline Soil Organic N & 29803 & & 29687 & 29803 & & 29634 \\
\hline Initial Residue N & 46 & & 53 & 53 & & 59 \\
\hline Soil $\mathrm{NO}_{3}$ & 150 & & 70 & 101 & & 61 \\
\hline Soil $\mathrm{NH}_{4}$ & 8 & & 6 & 8 & & 6 \\
\hline Leached $\mathrm{NO}_{3}$ & & -117 & & & -123 & \\
\hline N Denitrified & & -21 & & & -25 & \\
\hline Fertilizer N & & 360 & & & 360 & \\
\hline Organic residue & & 195 & & & 197 & \\
\hline N Uptake from Soil & & -608 & & & -614 & \\
\hline Total N & 30007 & -191 & 29816 & 29965 & -205 & 29760 \\
\hline
\end{tabular}

Table 2. Nitrogen balance of DT treatment in the upper $100 \mathrm{~cm}$ soil profile $\left(\mathrm{N} \mathrm{kg} \mathrm{ha}^{-1}\right)$.

\begin{tabular}{|c|c|c|c|c|c|c|}
\hline & \multicolumn{3}{|c|}{ Non-irrigated } & \multicolumn{3}{|c|}{ Irrigated } \\
\hline & Initial & & Final & Initial & & Final \\
\hline & Oct 192003 & Balance & Oct 202006 & Oct 192003 & Balance & Oct 202006 \\
\hline $\mathrm{NO} \mathrm{kg} \mathrm{ha}^{-1}$ & & & & & & \\
\hline Soil Organic N & 30467 & & 30163 & 30467 & & 30197 \\
\hline Initial Residue N & 37 & & 57 & 38 & & 45 \\
\hline Soil $\mathrm{NO}_{3}$ & 65 & & 49 & 48 & & 32 \\
\hline Soil $\mathrm{NH}_{4}$ & 5 & & 5 & 5 & & 5 \\
\hline Leached $\mathrm{NO}_{3}$ & & -39 & & & -65 & \\
\hline N Denitrified & & -13 & & & -29 & \\
\hline Fertilizer N & & 0 & & & 0 & \\
\hline Organic residue & & 174 & & & 116 & \\
\hline N Uptake from Soil & & -422 & & & -301 & \\
\hline Total N & 30574 & -300 & 30274 & 30558 & -279 & 30279 \\
\hline $\mathrm{N} 120 \mathrm{~kg} \mathrm{ha}^{-1}$ & & & & & & \\
\hline Soil Organic N & 30467 & & 30391 & 30467 & & 30349 \\
\hline Initial Residue N & 44 & & 58 & 46 & & 57 \\
\hline Soil $\mathrm{NO}_{3}$ & 149 & & 63 & 91 & & 50 \\
\hline Soil $\mathrm{NH}_{4}$ & 7 & & 6 & 7 & & 6 \\
\hline Leached $\mathrm{NO}_{3}$ & & -102 & & & -115 & \\
\hline N Denitrified & & -35 & & & -39 & \\
\hline Fertilizer $\mathrm{N}$ & & 360 & & & 360 & \\
\hline Organic residue & & 198 & & & 168 & \\
\hline N Uptake from Soil & & -570 & & & -523 & \\
\hline Total N & 30667 & -149 & 30518 & 30611 & -149 & 30462 \\
\hline
\end{tabular}

As a result of irrigation, it was observed a significant yield drop (0.4-2.5 $\mathrm{t} \mathrm{ha}^{-1}$, depending on the cultivation method and the crop year) in the non-fertilized treatment. The extent of yield drop was lower on fertilized plots and even a slight yield surplus was observed in the case of WP $\left(0.5-0.6 \mathrm{t} \mathrm{ha}^{-1}\right)$ - with the exception of 2005 (Figure 1). This phenomenon is in close correlation with the fact that there was more precipitation 
during the growing period of the examined 3 years than the average of 50 years. The high amount of precipitation, along with the irrigation water used, led to yield decrease on the non-fertilized, strongly nitrogen-deficient plots of the long-term experiment. The examinations of Huzsvai-Ványiné (2005) also verify the results above. Based on their observations, irrigation can increase maize yield only in the case of a sufficient level of nutrient supply.
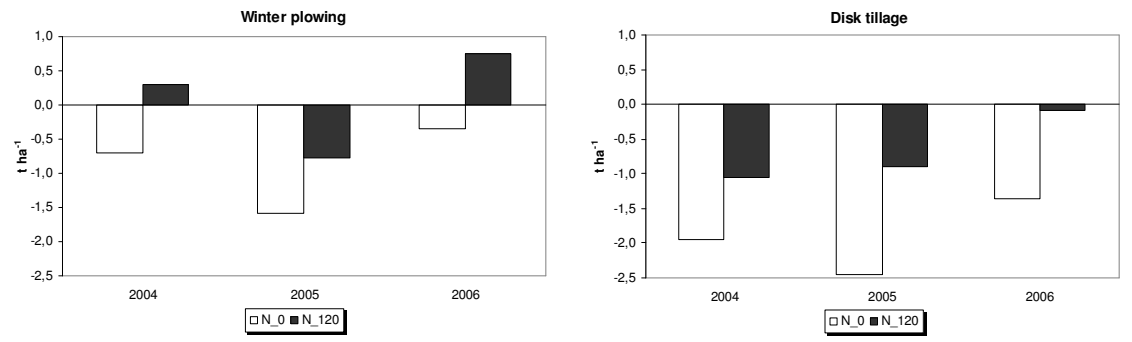

Figure 1. Effect of irrigation and fertilization on maize yield in different tillage treatments (Debrecen, 20032006)

\section{Conclusions}

Based on the examinations carried out in the long-term experiment, in some crop years that had more precipitation than average, irrigation leads to significant yield drop on non-fertilized plots. The research results draw attention to the establishment of harmony between nutrient and water supply. Under irrigated conditions, the effect of favorable water supply can only be utilized by applying proper amount of nutrients.

\section{Acknowledgements}

This work was supported by the Gábor Baross Program of the National Office for Research and Technology (NKTH OMFB-00820/2009) and the János Bolyai Research Scholarship of the Hungarian Academy of Sciences.

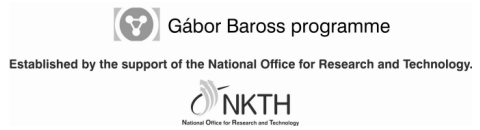

\section{References}

Fodor N. - Gabriella Máthéné-G. - Klára Pokovai - Géza J. Kovács.: 2002. 4M - software package for modelling cropping systems. European Journal of Agronomy, 18: 389-393.

Huzsvai L. - Rátonyi T. - Megyes A. - Sulyok D.: 2005. The effect of reduced tillage methods on physical characteristics of the soil and organic matter cycles. Cereal Research Communications, 33: 1. 399-402.

Huzsvai L. - Ványiné Széles A.: 2009. Water stress. In which cases does irrigation reduce the yield of maize? Cereal Research Communications, 37: Suppl. 1, 45-48.

Lelkes, J.: 2001. Az öntözés és szabványosítás. Poszter anyag. Készült a Magyar Tudomány Napja alkalmából. TSF MVKK. Szarvas.

Nagy J.: 2008. Maize production. Akadémia Kiadó, Budapest, 393. 


\title{
PESTICIDE CONTAMINATION IN SURFACE WATER AND SOIL IN HUNGARY
}

\author{
Mária MÖRTL - Erik MALOSCHIK - Judit JURACSEK - András SZÉKÁCS
}

Department of Ecotoxicology and Environmental Analysis, Plant Protection Institute, Hungarian Academy of Sciences, 1022 Budapest, Herman Ottó 15, Hungary, mortl@julia-nki.hu

\begin{abstract}
Ongoing systematic monitoring of pesticide residues in environmental matrices in Hungary since 1999 revealed extensive point contamination of both surface water and soil throughout the country. Major soil contaminant pesticides appeared to be DDT (and its metabolite DDE), lindane and atrazine at highest levels of 10 to $400 \mathrm{ng} \mathrm{g}^{-1}$. Most common water polluting pesticide active ingredients include atrazine and acetochlor at concentrations of 0.1 to $10 \mathrm{ng} \mathrm{ml}^{-1}$, as well as diazinone and trifluralin at lower levels. Chlorophenoxy acid type herbicide residues, dichlorprop, MCPA and 2,4,5-T, detected by a novel derivatization technique, were occasionally found at concentrations of $0.004-0.03 \mathrm{ng} \mathrm{ml}^{-1}$. Irrigation water is often contaminated with diazinone, atrazine or trifluralin, causing unintended pesticide exposure of irrigated soil and the environment, in general. Particularly at risk are watershed areas of pesticide production or formulation facilities and depositories, as well as corn growing regions. Atrazine and acetochlor contamination of the river Danube reaches raw drinking water, possibly causing continuous exposure as a prerequisite for chronic diseases. Some of the detected pesticide contamination appear to be persistent, questioning sustainability of certain existing agricultural technologies.
\end{abstract}

Keywords: pesticide, residue analysis, environmental sample, soil, ground water, surface water, gas chromatography, mass spectrometry, derivatization

\section{Introduction}

Sustainability of agricultural technologies, including intensive agriculture, integrated pest management and ecological farming, is focused on both the quality of soil and the environment (Larson and Pierce, 1994). The most important motives for the application of risk-reduction measures related to agricultural technologies has been to protect groundwater resources and to avoid human exposure to contaminants via drinking water from ground sources. Due to their impact on biodiversity, pesticide inputs to be reduced to the minimum level possible have been emphasized (McLaughlin and Mineau, 1995). The objective of the monitoring study reported hereby was to develop a soil and water contamination monitoring subsystem capable of complex survey of typical soil contaminants, using up-to-date sampling and measurement techniques, and therefore, eliminating environmental protection and environmental analytical limitations due to the agricultural focus of the presently functioning monitoring systems.

\section{Materials and methods}

\section{Chemicals}

Pesticide active ingredients as analytical standards of the target analytes were provided by the Plant Protection and Soil Conservation Directorate of Hungarian Agricultural Office (PPSCD HAO), or were purchased from Riedel-de Haën (Seelze, Germany). Organic reagents and solvents were purchased from Merck (Darmstadt, Germany), Fluka (Buchs, Switzerland) or Aldrich (Milwaukee, USA). CarboPrep-90 (500 mg, 6 $\mathrm{ml})$ and Carbograph (200 mg, $6 \mathrm{ml}$ ) columns were purchased from Restek (Bellefonte, PA, USA). For derivatization of chlorophenoxy acid type herbicides $t$ butyldimethylsilyl $N, N$-dimethyl carbamate was used (Maloschik et al., 2010). 


\section{Gas chromatography - mass spectrometry}

Gas chromatography coupled with mass spectrometry (GC-MS) was performed using a Varian Saturn 2000 workstation, equipped with a Varian 8200 autosampler. A Chrompack CP-Sil8 CB (low bleed/MS) analytical column (30 m x $0.25 \mathrm{~mm}, 0.25 \mu \mathrm{m})$ was used. The carrier gas was helium $\left(99.9999 \%\right.$ purity, $\left.1 \mathrm{ml} \mathrm{min}^{-1}\right)$. The temperature program for GC: initial temperature $130^{\circ} \mathrm{C}$, linear gradient of $20{ }^{\circ} \mathrm{C} \mathrm{min}{ }^{-1}$ to $270{ }^{\circ} \mathrm{C}$, held for $3 \mathrm{~min}$. (Injector temperature $280{ }^{\circ} \mathrm{C}$, injection $1 \mu \mathrm{l}$, split ratio 1:100.) Compounds were analyzed on GC-MS in the full scan mode, quantification was carried out using mass chromatograms for selected characteristic fragment ions extracted from the full scan spectra of the analytes. Mass spectra were obtained in electron impact mode $(70 \mathrm{eV})$ in the range between 70 and $400 \mathrm{~m} / \mathrm{z}$.

\section{Sample preparation}

Air-dried soil samples (10 g) were extracted with $15 \mathrm{ml}$ of hexane/acetone (1:1), and the centrifuged supernatant was evaporated and resuspended in $1 \mathrm{ml}$ of ethyl acetate (Cairns and Sherma, 1992; Oldal et al., 2006). Water samples were filtered and subjected to solid phase extraction (SPE) (Majzik-Solymos et al., 2001; Maloschik etal., 2007) using CarboPrep-90 SPE columns (500 mg, $6 \mathrm{ml}$ ). Absorbed material from $1000 \mathrm{ml}$ of water was eluted from the SPE column with dichloromethane/methanol evaporated to final volumes of $1 \mathrm{ml}$ upon solvent exchange. Basic/neutral and acidic analytes were eluted in two consecutive steps (fractions 1 and 2) using dichloromethane/methanol $(8: 2 \mathrm{v} / \mathrm{v})$ and dichloromethane/methanol $(6: 4 \mathrm{v} / \mathrm{v})$ basified with $0.016 \mathrm{~mol} \mathrm{l}^{-1} \mathrm{KOH}$, respectively.

\section{Sample collection}

In national monitoring programs, 673 soil samples and 877 surface and ground water samples were collected between 1999 and 2009 from agricultural fields and industrial sites in Hungary. Among agricultural areas, three types of land usage have been involved: arable lands under intensive cultivation, arable lands under organic farming and pasture. Spatial setting of sampling accuracy was supported by a global positioning system. Soil and water sampling were carried out according to national standards MSZ 21470-1:1998 (Hungarian Standards Institution, 1998) and MSZ ISO 5667 (Hungarian Standards Institution, 1995) before and after agricultural pesticide applications.

\section{Results and discussion}

Within the scope of national survey programs, main pesticide active ingredients, metabolites and other organic micropollutants (i.e. acetochlor, atrazine, carbofuran, DDT/DDE, diazinon, dieldrin, dimetachlor, endrin, fenoxycarb, glyphosate, HCHs, heptachlor, metolachlor, metribuzine, phorate, propisochor, simazine, terbutryn, trifluralin) and related compounds (i.e. AMPA) or compound groups (camphechlor) were monitored by GC-MS. The analyte range was expanded to chlorophenoxy acid herbicides using a new silylation method developed in our laboratory (Maloschik et al., 2010). Although various reagents are used for the formation of thermally stable and volatile derivatives of analytes, these procedures require either high temperature or hazardous chemicals. Silylating agent $t$-butyldimethylsilyl $N, N$-dimethyl carbamate was 
proven to be a convenient agent effective at room temperature resulting derivatives of improved mass spectral properties (less fragments and higher abundance) and hydrolytic stability. The simple and quantitative derivatization procedure is well suited for the trace level determination of various chlorophenoxy acids with LODs of 5 to $100 \mathrm{pg}$ applying GC with EI-MS detection in full scan mode.

Two SPE methods using graphitized carbon black cartridge were tested for the preparation of water samples for chemical analysis. Single-step elution (Ding et al., 2000) provided high recoveries for 2,4-D and 2,4,5-TP (93-102\%), and recovery levels complied with literature data $(75-95 \%)$, but recoveries were lower for most of the analytes than in the other procedure. A two-step procedure (Majzik-Solymos et al., 2001; Di Corcia and Marchetti, 2001), allowing isolation of acidic compounds from basic/neutral ones by two consecutive elution steps using a single sample loading step, is the suggested method of choice by PPSCD HAO for pesticide residue monitoring. Obtained recoveries in the two-step procedure were limited by the fact that a substantial proportion $(2-17 \%)$ of the analytes was detected in fraction 1 as well. Nonetheless, sufficient recoveries (84-97\%) in agreement with reported values (77-101\%) were determined, therefore, this method has been applied in this study.

As for pesticide contamination detected in surface and ground water samples within a 3year survey (1999-2001), alarmingly high point type contamination (> $\left.10 \mathrm{ng} \mathrm{ml}^{-1}\right)$ was found at 2 sites $\left(2.2 \%\right.$ of all sites), medium contamination $\left(1-10 \mathrm{ng} \mathrm{ml}^{-1}\right)$ at 14 sites $(15.6 \%)$ and low contamination $\left(<1 \mathrm{ng} \mathrm{ml}^{-1}\right)$ at 32 sites $(35.2 \%)$. Within a two-year sampling campaign (2008-2009, 2010 is to be completed) of 202 water samples analyzed, 76 samples contained detectable contamination by one or more target compounds (contamination was marginal in 11 cases, the most contaminated samples arrived from an identified illegal contamination site scheduled for remediation). Therefore, contamination rate found was 18-67\%. Pesticide contamination in soil samples appeared to be more uniform in time: of 423 soil samples analyzed in 2008200977 samples contained detectable contamination by one or more target compounds (contamination rate $17-19 \%)$. Most common water contaminants were acetochlor (0.02$\left.3900 \mathrm{ng} \mathrm{ml}^{-1}\right)$, atrazine $\left(0.5-100 \mathrm{ng} \mathrm{ml}^{-1}\right)$, metolachlor $\left(0.001-56 \mathrm{ng} \mathrm{ml}^{-1}\right)$, trifluralin (0.8-9 $\left.\mathrm{ng} \mathrm{ml}^{-1}\right)$ and diazinon $\left(0.001-0.85 \mathrm{ng} \mathrm{ml}^{-1}\right)$, the most common soil contaminants appeared to be atrazine (10-580 $\mathrm{ng} \mathrm{g}^{-1}$ ), trifluralin (3-200 $\left.\mathrm{ng} \mathrm{g}^{-1}\right)$, acetochlor/metolachlor (5-80 $\left.\mathrm{ng} \mathrm{g}^{-1}\right)$, as well as DDT/DDE (38-460 $\mathrm{ng} \mathrm{g}^{-1}$ ) and lindane/HCH (7-103 $\left.\mathrm{ng} \mathrm{g}^{-1}\right)$. Found contamination levels were in certain cases alarming as the corresponding harmonized EC Directive (European Parliament and Council, 2006), effective in Hungary as well, sets the maximum residue limit (MRL) of $0.1 \mathrm{ng} \mathrm{ml}^{-1}$ for a given pesticide compound and $0.5 \mathrm{ng} \mathrm{ml}^{-1}$ for all pesticide residues in subsurface water.

Chlorophenoxy acid herbicide residues were detected in eight cases within 115 surface and ground water samples collected from Békés county in Hungary at 14 sampling sites in 2009. One surface water sample (Battonya region) contained 2,4,5-T, five ground water samples (Orosháza region) contained dichlorprop, and in two ground water samples (Csorvás region) MCPB was found. Analyte concentrations found ranged between 0.004 and $0.030 \mathrm{ng} \mathrm{m}^{-1}\left(0.03,0.004-0.012\right.$ and $0.005 \mathrm{ng} \mathrm{ml}^{-1}$ for 2,4,5-T, diclorprop and MCPA, respectively), in all cases near to the LOD. Contamination prevalence was found to be $7 \%$ over the year, yet, as all contaminated samples were found within a single sampling regime, the within regime contamination incidence was 
to an alarming $24 \%$. The severity of this finding is lessened by the fact that only trace amounts were detected, yet it is of considerable concern, however, that one of the found contaminants $(2,4,5-\mathrm{T})$ is a herbicide banned in Hungary since 1994.

\section{Conclusions}

Pesticide contamination repeatedly occurs both in surface and ground waters and in soil. While such surface water pollution considerably varies over the years (contamination prevalence $18-65 \%$ ), possibly due to meteorological conditions, soil contamination appears to be more invariable (contamination prevalence 17-19\%). Persistent soil contaminants, including atrazine, acetochlor and trifluralin may wash out from lower soil layers, and appear as water contaminant. EU regulations set MRL for given pesticides $\left(0.1 \mathrm{ng} \mathrm{ml}^{-1}\right.$ in water and $100 \mathrm{ng} \mathrm{g}^{-1}$ in soil) with a safety factor of 100 . Therefore, should contamination levels exceed 100-fold of the MRL, they are considered hazardous to human health. In the case of the present survey, acetochlor, atrazine and metolachlor were found above this value (100 MRL) in 8 surface water samples (4\% of all water samples). In contrast, pesticide residue contaminants in soil have not exceeded $100 \mathrm{MRL}$ in any case.

\section{Acknowledgements}

This investigation was supported by research project MONTABIO (OM 00029/2008) by the National Office for Research and Technology of Hungary (NKTH JÁP).

\section{References}

Cairns T. - Sherma J. (eds).: 1992. Emerging strategies for pesticide analysis. CRC Press, Boca Raton, FL, USA. 24-25.

Di Corcia A. - Marchetti M.: 2001. Multiresidue method for pesticides in drinking water using a graphitized carbon black cartridge extraction and liquid chromatographic analysis. Anal. Chem., 63: 580-585.

Ding W-H. - Liu C-H. - Yeh S-P.: 2000. Analysis of chlorophenoxy acid herbicides in water by large-volume on-line derivatization and gas chromatography-mass spectrometry. J. Chromatogr. A, 896: 111-116.

European Parliament and Council.: 2006. Directive 2006/118/EC (12 Dec 2006) on the protection of groundwater against pollution and deterioration. Offic. J. Eur. Union L 372: 19-31.

Hungarian Standards Institution.: 1995. Water quality. Sampling: Part 1. Guidance on the design of sampling programmes and sampling techniques (ISO 5667-1:2006). Hungarian Standard (MSZ ISO) 5667-6:1995, Budapest, Hungary (in Hungarian).

Hungarian Standards Institution.: 1998. Environmental soil investigation. Sampling. Hungarian Standard (MSZ) 21470-1:1998, Budapest, Hungary (in Hungarian).

Larson WE. - Pierce FJ.: 1994. The dynamics of soil quality as a measure of sustainable management. In: Doran JW. - Coleman DC. - Bezdicek DF. - Stewart BA. (eds.), Defining Soil Quality for a Sustainable Environment. Soil Sci. Soc. Am., Special Publication 35. SSSA, Madison, WI, USA, 37-52.

Majzik-Solymos E. - Visi E. - Károly G. - Beke-Bérczi B. - Győrfi L.: 2001. Comparison of extraction methods to monitor pesticide residues in surface water. J. Chromatogr. Sci., 39: 325-331.

Maloschik E. - Ernst A. - Hegedüs Gy. - Darvas B. - Székács A.: 2007. Monitoring water polluting pesticides in Hungary. Microchem. J., 85: 88-97.

Maloschik E. - Mörtl M. - Székács A.: 2010. Novel derivatisation technique for the determination of chlorophenoxy acid type herbicides by gas chromatography-mass spectrometry. Anal. Bioanal. Chem., in press.

McLaughlin A. - Mineau P.: 1995. The impact of agricultural practices on biodiversity. Agricult. Ecosyst. Environ., 55: 201-212.

Oldal B. - Maloschik E. - Uzinger N. - Anton A. - Székács A.: 2006. Pesticide residues in Hungarian soils. Geoderma 135: 163-178. 


\title{
PLANT GROWTH AND DEVELOPMENT IN HYDROCULTURAL GROWING
}

\author{
Péter LÉVAI ${ }^{1}$ - Zsuzsa TURI FARKAS ${ }^{2}-$ Tímea KISS $^{3}$ \\ ${ }^{1}$ Kecskemet College, Faculty of Horticultural, H 6000 Kecskemét, Erdei F. tér 1-3., levai.peter@kfk.kefo.hu \\ ${ }^{2}$ Kecskemet College, Faculty of Horticultural, H 6000 Kecskemét, Erdei F. tér 1-3., \\ turine.zsuzsa@kfk.kefo.hu \\ ${ }^{3}$ Kecskemet College, Faculty of Horticultural, H 6000 Kecskemét, Erdei F. tér 1-3., timea.kiss@kfk.kefo.hu
}

Abstract: The closed system hydro-cultural growing is environment-friendly, the chemical fertilizer used for nourishing material supply does not contaminate the soil water and it is possible to eliminate the chemical materials accumulating during the disinfection of the soil getting into the environment. It can be mechanized and regulated well so the optimum growing conditions can be fixed for the plant and as a consequence higher yield can be reached both for the carnation and for Zantedeschia. Growing method with saving both the nourishing material and the water. Taking all the above into consideration timing is easier and better, it can be programmed better than the traditional chemo-cultural growing.

Keywords: hydro-cultural, plant growth, carnation, Zantedeschia,

\section{Introduction}

The importance of hydro-cultural growing is significantly increasing. We have been dealing with the hydro-cultural growing of cut flowers at the Department of Ornamental Plant Growing and Maintenance of Gardens at the College Faculty of Horticulture at Kecskemét College since 1988. We started our experiments by growing carnation in growing establishment without soil then we introduced other species of cut flowers and potted ornamental plants into our research work.

Our aim was to examine the effect of Grodan and PU-sponge media on the growth, the yield of flowers, the diameter of the flowers and the length of the stem concerning the species of carnation 'Pink Castellaro'.

Our aim was to examine three types of growing and two plantation media, PU-sponge and the mixture of soil applied for container growing as well as two types of growing establishment, Filclair greenhouse and Primör-1 glass-house on the growth, the yield, the length of the flower and the stem and the vase life of Zantedeschia.

\section{Materials and methods}

The experiments of hydro-cultural growing of carnation were carried out by the French Filclair growing establishment, growing was arranged in a closed, circular system. The planting of shoots with roots was arranged by 40 pieces $/ \mathrm{m}^{2}$ at the end of May. We applied PU-sponge and Grodan as the medium of plantation, the length of the growing season was one year. The experiment was carried out by repeating the procedure four times. The supply of nutritional material was made by using complex chemical fertilizer, the $\mathrm{pH}$ of the nourishing solution was 5,0-6,5, the conductivity was 2,5-3,5 $\mathrm{mS}$ and these parameters were continuously controlled. The height of the plants was measured from September to the end of the growing period each week. We measured the quantity of the picked flowers from the beginning of blooming each time. We chose 
10-10 of the picked flowers by random choice and measured the characteristics of flower quality: the diameter of the flower and the length of the stem.

We used Zantedeschia aethiopica 'Perle von Stuttgart' species for hydro-cultural growing of Zantedeschia. We planted the rootstocks in the second decade of July in both years. We repeated the tests four times. In case of Filclair growing establishment we grew Zantedeschia together with carnation according to the details above. In Primör1 growing establishment we assured the same conditions as those in the other establishment but it had soil heating as well.

We measured the height of the plants from October to March, we tested the quantity of the flowers, the length of the flowers and the length of the stem from September to April. The measuring of Zantedeschia was arranged according to the methods used for carnation.

We processed the data by Microsoft Excel 2000 program on IBM-compatible PC. During the statistical analysis we made variety analysis and calculated the SD 5\% values by F-test Student-type.

\section{Results and discussion}

The effect of the media on the height of the carnation

In case of the hydro-cultural growing of carnation both the polyurethane-ether sponge and Grodan had a good effect on the growth of the plant, both are adequate as a plantation media but the stock grown in the sponge was higher.

The effect of the media on the yield of the carnation

We managed to reach the average flower yield of 7-9 flowers per stem (Figure 1.) characteristic of the traditional chemo-cultural growing in case of hydro-cultural growing in polyurethane-ether sponge and in Grodan that is both are adequate plantation media for hydro-cultural growing.

The effect of the media on the flower diameter of the carnation

During the two growing seasons of the experiments the average diameter of the flowers planted in polyurethane-ether sponge and in Grodan reached the parameters of $1^{\text {st }}$ class flowers that is 7-cm flower diameter. We did not experience significantly better results in case of the two media so both are adequate for the hydro-cultural growing of carnation.

The effect of the media on the length of the flower stem of carnation

The plantation media influenced neither the yearly nor the monthly length of the stem significantly in the years of research.

Taking the yearly average into consideration we reached the requirement of $1^{\text {st }}$ class quality that is 55-60-cm stem length in case of both media.

Considering all the above both polyurethane-ether sponge and Grodan are adequate media for hydro-cultural growing. 


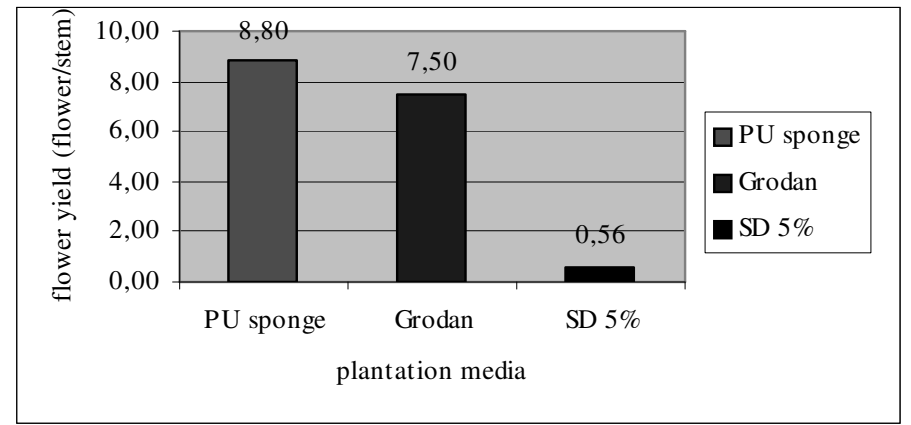

Figure 1. The effect of plantation media on the yearly yield of carnation 'Pink Castellaro'

$$
\text { (Kecskemét, 1999-2000.) }
$$

The effect of the media on the height of Zantedeschia

The plants grown in container, soil mixture produced higher growth. It can be explained by the fact that the plantation media gets warmer sooner and it has got a positive effect on the development of the plants (Figure 2).

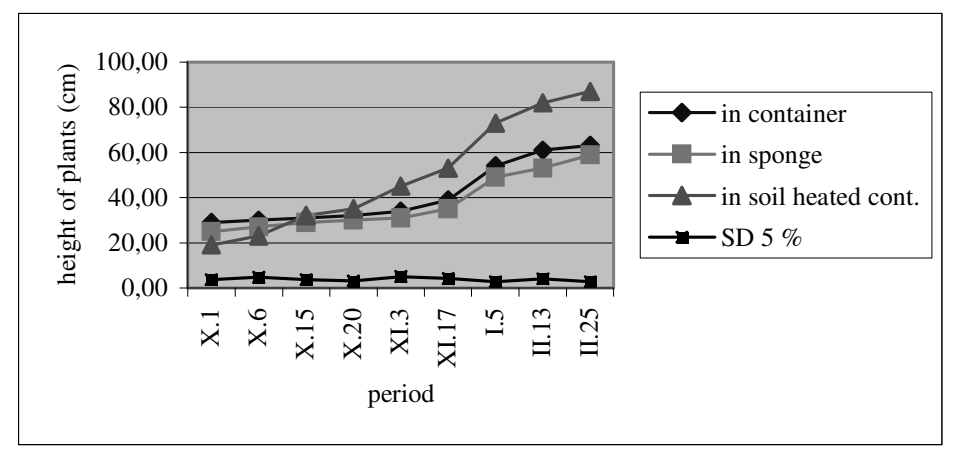

Figure 2. The effect of the growing methods on the height of Zantedeschia (Kecskemét, 2002-2003.)

The effect of the growing establishment on the height of Zantedeschia

During the period of experiments the height of the stock in container, planted in Primör1 greenhouse increased by leaps in the period following November; it can be explained by the effect of starting the soil heating and its effect on the development of the plants. The effect of the growing establishment on the flower length of Zantedeschia In the period of the experiment neither Primör-1 nor Filclair had significant effect on the length of the flower, concerning the length of the flower both growing establishments are adequate for the hydro-cultural growing of Zantedeschia.

The effect of the growing establishment on the length of the stem of Zantedeschia

The length of the flower stem in Primör-1 greenhouse increased significantly from December on that can be explained by starting soil heating; the quality of the picked 
flowers was extra till the end of the survey period. Taking all the above into consideration it is advisable to install soil heating in order to have better flower quality.

\section{Conclusions}

Concerning environmental protection PU sponge is more and more adequate media for growing carnation since it can be used until complete decomposition.

Both PU sponge and Grodan have got a favourable effect on the growth of the plant, the yield of the flowers and the flower quality characteristics that is why Grodan is also an adequate media for the hydro-cultural growing of carnation.

We recommend PU sponge as a plantation media for the hydro-cultural growing of Zantedeschia but it is necessary to have soil heating in the growing establishment from the point of adequate development, high flower yield and long stem as well as extra quality flower since the sponge gets warmer harder than the soil mixture.

Zantedeschia grown in hydro-culture lasts longer due to the better supply of nourishing material characteristic of hydro-cultural growing.

\section{Literature}

Benoit, F. - Ceustermans, N.: 1990. The use of recycled polyurethane (PUR) as an ecological growing medium. Plasticulture, 4, 41-48.

Benoit, F. - Ceustermans, N.: 1995. Horticultural Aspects of Ecological Soilless Growing Methods. Acta Horticulturae, 346, 11-18.

Cruz Castillo, J. G. - Cárdenas Alonso, M.: 1998. The calla lily (Zantedeschia spp.): a new crop for Veracruz, Mexico Proceedings of the Interamerican Society for Tropical Horticulture 41, 84-87.

Guba, W. - Starck, J. R. - Strojny, Z.: 1993. The effect of different pH in root environment on yield and nutrition level of carnation grown in rockwool. Journal-of-fruit-and-Ornamental-Plant-Research. 5, (1) 27-33.

Gugenhan, E.: 1991. Calla im Aufwind. Zierpflanzenbau, XXX. (24) 1009-1010.

Jolánkai M - Németh T.: 2007. Agronómiai és környezetvédelmi elvárások. In: Németh T, Neményi M, Harnos Zs (ed.) A precíziós mezőgazdaság módszertana. Szeged: JATE Press - MTA TAKI, 2007. 63-76.

Jolánkai M.: 2008. Energy cropping considerations. KLÍMA-21 FÜZETEK 55: 80 - 86.

Kovács, A.: 2000. Talaj nélküli termesztés. 101-121. In: Balázs S. (Szerk.) A zöldséghajtatás kézikönyve Budapest: Mezőgazda Kiadó

Leinfelder, J. - Röber, R.: 1991.Der Anbau von Edelnelken im geschlossenen System. Gartenbau, 38 (3) 4043.

Lévai P. - Turiné Farkas Zs.: 2007. The development of hidroponic way of growing in floriculture. "Lippay János - Ormos Imre - Vas Károly" Tudományos Ülésszak 2007. november 7-8. Összefoglalók, Kertészettudomány. Budapesti Corvinus Egyetem, Kertészettudományi Kar, Budapest 63.

Schmidt, G. (Ed.): 2002. Növényházi dísznövények termesztése. Budapest: Mezőgazda Kiadó. 622.

Turiné Farkas, Zs.:2002. Kála, tölcsérvirág - Zantedeschia spp. 308-312. In: Schmidt, G. (Ed.): Növényházi dísznövények termesztése. Budapest: Mezőgazda Kiadó. 622. 


\title{
RESILIENCE TO DROUGHT: WHETHER IT IS POSSIBLE?
}

\author{
Sándor SZALAI
}

Szent István University, Páter Károly u. 1, 2103. Hungary. e-mail: szalai.sandor@mkk.szie.hu

Abstract: The influence of drought is investigated on the detrended maize time series. The effect of drought in different part of the year is shown. The severity of drought is described by SPI index, and the different drought date and length is compared with the detrended maize yield time series.

Keywords: drought, SPI, effect on yield

\section{Introduction}

Water scarcity and droughts are becoming increasingly important problems in Europe and in many regions all over the world. Lesser water resources can reduce soil fertility, translate into land degradation, favour desertification and provoke serious impacts in societies and the environment.

Drought has not an overall definition, and the phenomena drought, aridity and water scarcity are frequently misused. While drought means a temporary decrease in water availability due, for instance, to rainfall deficiency, water scarcity means that water demand exceeds the water resources exploitable under sustainable conditions. Drought is a recurrent natural phenomenon, while water scarcity is directly connected to the human activity. Water scarcity occurs where there are insufficient water resources to satisfy long-term average requirements. It refers to long-term water imbalances, combining low water availability with a level of water demand exceeding the supply capacity of the natural system.

Droughts can occur anywhere in Europe, by definition in both high and low rainfall areas and in any seasons. The impact of droughts can be exacerbated when occurring in a region with already low water resources, with mismanagement of water resources and with imbalances between water demands and the supply capacity of the natural system. In some regions, the severity and frequency of droughts can lead in the future to water scarcity situations due to overexploitation of available water resources. Consequently, attention needs to be paid on the synergies between the phenomenon of drought and the phenomenon of water scarcity, especially in the river basins being affected by water scarcity.

In addition, climate change could decrease available water resources, worsening scenarios. Drought episodes, contrary to other extreme events, such as floods, have a slow onset, are difficult to prevent, and the geographic impacted area or specific duration can be difficult to identify (Estrela et al., 2008).

Drought damages are among the largest damages caused by natural disasters, but they are not well published and known, because the methodology of calculation has not been established. The possible agricultural drought damage is estimated in this paper, investigating the drought events in different seasons and their potential effects on the yields. 


\section{Materials and methods}

As the drought has no universal definition, has not universal measure as well. Therefore, several drought indices used to be applied for drought monitoring purposes usually. Only the SPI index will be used this time, because it is a simple, generally used tool for drought measurements (McKee et al., 1993). Its benefits are the use only precipitation data (i.e. low input data needs), versatility and the consistent values. Among the disadvantages we can list the dependency on the basic period, it could be problems at the transformation into the normal distribution and the poor input parameters (no knowledge about the soil, temperature, etc.).

Theoretically, small scale investigations are preferred, but the availability of data is possible on county level from the database of Central Statistical Office. Therefore, we used the spatial scale for the county, temporal scale for the yields is year and for the SPI month.

The maize yield time series was used for the Baranya county, and the SPI time series for the meteorological station Pécs from 1922-2001. The lack of data is in 1944, 1945, 1946 and 1949.

\section{Results and discussion}

Fig 1 shows the original yield and the fitted trend time series. The tendency is stable from 1922 to 1955, growing from 1956 to 1984, decreasing from 1985 to 1990 and stable from 1991 to 2001 . The Fig. 2 shows the different time series, i.e. the difference between the original time series and the trend time series. We assume the follow:

1. the changes of yield are the consequence of development of agrotechnology, seeds, etc.

2. the remaining values are more depending on the meteorology of the given year. Therefore, the drought indices will be compared with the different time series.

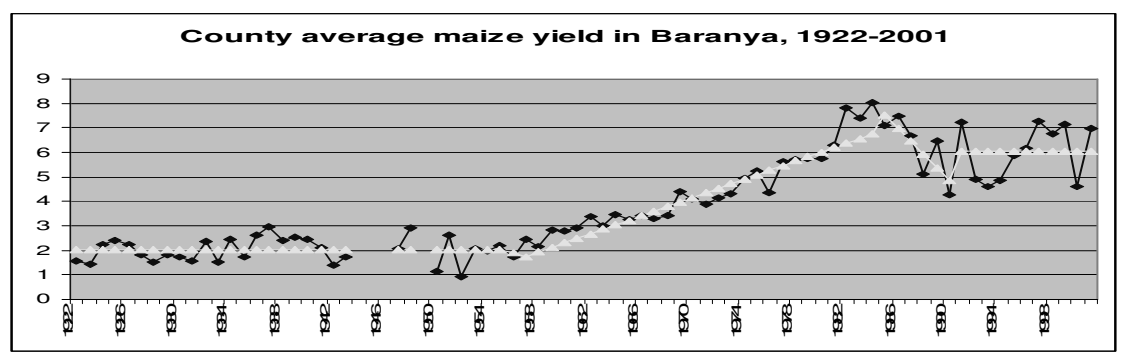

Figure 1. The original and the trend time series for maize in Baranya county 


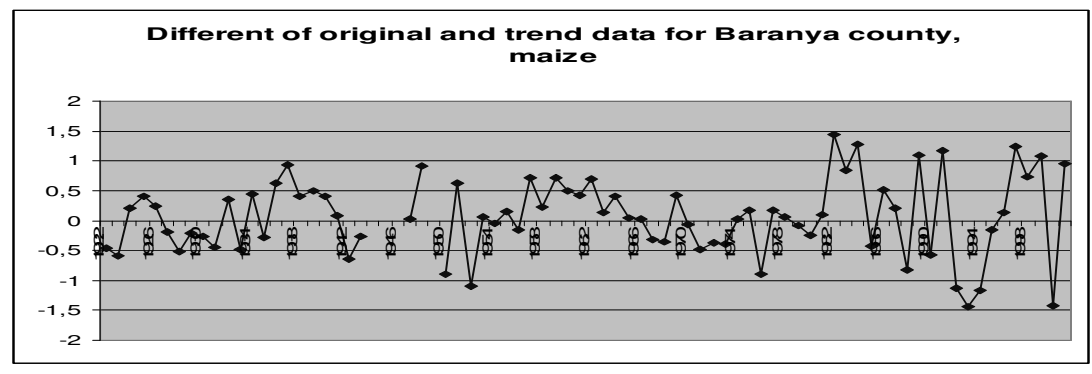

Figure 2. The different time series assumed mainly influenced by meteorology

The smaller variability at the beginning of the time series and the larger ones at the end could be explained on different ways. The difference is an absolute value, therefore it can be, that the same influence has larger impact because of the larger yield. From the other side, it is known, that drought events are more common recently, and their severity is growing, therefore they can cause larger effects.

The correlation of different length of SPI with the residual yield time series for the month of August is shown on Tab. 1.

Table 1. Correlation of different length of SPI for August with the residual yield time series

\begin{tabular}{|c|c|}
\hline Length of SPI basis & Correlation \\
\hline \hline 1 & $17 \%$ \\
\hline 2 & $33 \%$ \\
\hline 3 & $42 \%$ \\
\hline 4 & $44 \%$ \\
\hline 5 & $35 \%$ \\
\hline 6 & $35 \%$ \\
\hline 7 & $35 \%$ \\
\hline
\end{tabular}

According to the Tab. 1. the largest correlation has the yield with the May-August precipitation. After that, the maximum value of the residual time series was taken. It happened in the year of $1982(1,44)$. Tab. 2 shows, that February, April and May was dry and very dry in Pécs. Despite of that, the residual value is very high. The reason for that can be the wet December in 1981 (SPI=1,88, which means very wet conditions), and the relatively high precipitation in summer (3-months SPI $=1,54$, very wet conditions), each months had higher than average precipitation, and June and August were wetter than the normal.

The lowest value in the residual time series was in $1993(-1,44)$. In this year almost all months were drier than the average, but only one (May) had extremely dry conditions. (The value of -1 is the threshold value of SPI between the normal and the dry conditions, and on appropriate way, 1 is the threshold between normal and wet conditions. 0 means the climatological average.)

If we compare the two extreme years, we find, that three extreme dry months were observed in the year of the highest value and only one with the lowest one. It can be assumed, that the effect of dry spring was reduced by the more wet winter (saturated soil) and by the wet summer in the most important development phases of maize in 
1982, while the sequential dry months had a large influence on the yield, even if they were not very dry, and there was a lack of water in the most important part of the plant development, i.e. in summer. The three driest months were in 1982, and only the forth driest month was measured in 1993, in comparison of the years. This result support the assumption, that the vulnerability of a given territory is larger to the smaller decrease of precipitation in a longer drier than average period, than in the equally distributed around average period.

Table 2. The one-month SPI values in 1982 (maximum value in the residual time series) and in 1993 (minimum value in the residual time series)

\begin{tabular}{|c|c|c|}
\hline Months & 1982 SPI values & 1993 SPI values \\
\hline 1 & $-0,95$ & $-0,81$ \\
\hline 2 & $-1,64$ & $-0,54$ \\
\hline 3 & 0,14 & 0,11 \\
\hline 4 & $-1,82$ & $-0,51$ \\
\hline 5 & $-1,61$ & $-1,5$ \\
\hline 6 & 1,1 & $-0,56$ \\
\hline 7 & 0,66 & 0,01 \\
\hline 8 & 1,34 & $-0,08$ \\
\hline
\end{tabular}

\section{Conclusions}

The paper made one additional evidence to the estimation, that not only the size of the natural disaster (drought in our case) determines the damage, but better the sensitivity of the environment. Therefore, a simple investigation of drought index size could not give general information about the whole process, because the effect of dry months can be taken up. The present research shows, that there is possible to have resilience to drought, even within one vegetation period. Another consequence of this investigation is, that the precipitation in appropriate time could be more important, than the quantity of the precipitation, therefore, the climate change investigations should pay more attention to the shift of the distribution of precipitation within a year.

\section{References}

Estrela, T. - Vargas, E. - Bonaiti, G. - Davy, T.: 2008. European Regional Process, Chapter 3. Water scarcity and droughts. Working Document of the WG Water Scarcity and Drought.

McKee, T. B. - Doesken, N. J. - Kleist, J.: 1993. The relationship of drought frequency and duration to time scales. Proceedings of the 8th Conference on Applied Climatology, Texas, TX, 233-236. 


\title{
ROLE OF SOIL WATER REGIME IN RESILIENCE OF MAIZE PRODUCTION
}

\author{
Fülöp Lajos DÓKA
}

Institue of Crop Sciences, Agronomy Faculty, Centre of Agricultural Sciences and Engineering, University of Debrecen, H-4032 Debrecen, Böszörményi str 138, doka@agr.unideb.hu

\begin{abstract}
Due to effect of global warming increased the prevalence of dry cropyear and number of extreme incident of weather. We examined the change of the time of water balance of soil and yield in 25 years old experiment, on chernozem soil, in different crop-rotation systems (mono-, bi- and triculture) in two extreme cropyear in 2007 and 2009 in maizestock. According to our results the values of waterdeficit of soil in maizestock were about $100 \mathrm{~mm}$ before the sowing time that grew because of considerable deficit of precipitation and high average temperature in months of summer in 2009. Values of waterdeficit achieved at the end of August the maximum and lessed a little bit to end of crop time. Decrease of waterstock stopped because of irrigation treatments in irrigated plots but the difference between two irrigation treatments (Ö1-Ö3) vanished at the end of summer, waterdeficit were higher with $17 \mathrm{~mm}$ in monoculture in irrigated plot than value of not-irrigated plot. Considerabler precipitation in Jun effected on waterbalance of soils of three of crop-rotation systems favourable, rapid waterloss starting to April began to lessen at the end of May and started to increase from early in July. Precipitation in Jun had positiv effect on yield also. The best of yields gave in biculture and in irrigated plots of three of crop-rotation systems Our scientific results proved that the agrotechnical elements (crop-rotation, irrigation) have important effect on the resilience of agro ecosystems.
\end{abstract}

Keywords: cropyear, water deficit, irrigation, maize, crop-rotation, yield

\section{Introduction}

The future possibilities of crop production will probably be widened or limited by the level of adaptation to climatic changes. The primary cause of drought damage is the lack of precipitation (Jolánkai-Birkás, 2009). The weather phenomena of the past 6 years verify the forecasts. Not only the more dry or wet periods are becoming frequent, but the number of extremities within a year or even in a season is increasing (Birkás, 2006). If there is no supply to the water uptaken from the soil (precipitation, irrigation), then the soil moisture level will decrease and the water uptake by plants will become more difficult. Therefore, it is worthwhile to continuously supply the water uptaken from the soil. The soil can balance the extremes of the natural environment to a certain extent and to provide the plants with water and nutrients from the stored stocks at a certain level for a shorter or longer period (Vad et al., 2007; Várallyay, 2006; VargaHaszonits et al., 2008). The year has a significant impact on the yield of maize, if the amount of precipitation is favourable during the season, outstanding yields can be achieved. In dry years, the intensity of photosynthesis and transpiration drops as a result of water stress and the yield can be halved as compared to a wet year (Hegyi et al, 2008; Jambrovic et al., 2008; Ceska et al., 2008; Hoffmann et al., 2007). Irrigation obviously has an effect on maize yield, but this is strongly influenced by the crop rotation, there is a tight correlation between the year, the water supply and the agrotechnical factors (crop rotation, fertilization, plant density (Pepó et al, 2008).

\section{Materials and methods}

The examinations were carried out in the years of 2007 and 2009 at the Experimental Station of the University of Debrecen at Látókép in the polyfactorial long-term 
experiment set up by Prof. László Ruzsányi in 1983 and supervised by Prof. Péter Pepó since 2004. The soil of the experiment is calcareous chernozem with a medium waterholding capacity. Soil cultivation, crop protection and harvest were performed uniformly. The tested hybrid was Reseda (PR37M81). To study the water cycle, soil samples were collected on 6 occassions (pre-sowing, post-harvest and at the major phenological phases) from each $20 \mathrm{~cm}$ layer from the $0-200 \mathrm{~cm}$ soil profile in 2007 and 2009 from the irrigated and non-irrigated parcels of all three crop rotation systems (mono-, bi- and triculture) with $\mathrm{N}_{120}+\mathrm{PK}$ fertilization and 60000 plants ha ${ }^{-1}$ plant density. The weight of the original soil samples was measured, then they were dried in a drying cupboard at $105{ }^{\circ} \mathrm{C}$. The dried samples were measured again and from the wet and dry weights we calculated the percent moisture by weight. Using the soil parameters, the water deficiency of the soil profile was calculated from the soil moisture values for the given measurement time and was expressed in $\mathrm{mm}$.

Table 1. More important meteorological datas (Debrecen - Látókép, 2007, 2009)

\begin{tabular}{|l|c|c|c|c|c|c|c|}
\hline Precipitation [mm] & April & May & June & July & August & September & Total \\
\hline \hline 2007. year & 3,6 & 54 & 22,8 & 39,7 & 77,6 & 86,1 & 283,8 \\
\hline 2009. year & 9,9 & 20,1 & 96,6 & 9,2 & 11,3 & 21,7 & 168,8 \\
\hline 30-year average & 42,4 & 58,8 & 79,5 & 65,7 & 60,7 & 38,0 & 345,1 \\
\hline Difference $(2009)$ & $-32,5$ & $-38,7$ & 17,1 & $-56,5$ & $-49,4$ & $-16,3$ & $-176,3$ \\
\hline Temperature [ $\left.{ }^{\circ} \mathrm{C}\right]$ & April & May & June & July & August & September & Total \\
\hline \hline 2009. year & 14,9 & 17,4 & 19,8 & 23,4 & 22,6 & 18,9 & 117 \\
\hline 30-year average & 10,7 & 15,8 & 18,7 & 20,3 & 19,6 & 15,8 & 100,9 \\
\hline Difference & 4,2 & 1,6 & 1,1 & 3,1 & 3 & 3,1 & 16,1 \\
\hline
\end{tabular}

Table 1 shows that the amount of precipitation in 2007 until August was much lower than the average of 30 years. The season of 2009 was even more dry (total precipitation of $168.8 \mathrm{~mm}$ ), the amount of precipitation was below the 30 -year average in all months except for June. The natural water supply had not been satisfactory already at the beginning of the season (sowing, emergence, early development). This trend continued also during the summer months. The lack of precipitation was accompanied by monthly mean temperatures higher than the 30-year average, which further increased the harmful effects of water deficiency.

\section{Results and discussion}

We studied the relationships between the precipitation in the season of 2009, irrigation and the soil water dynamics (Figure 1). Among the three crop rotation systems, the largest water deficiency was measured in monoculture. In parallel with increasing mean temperatures and decreasing precipitation, the water stock of the soil started to decrease, consequently, increasing water deficiency values were obtained. The favourable effect of precipitation in June on the soil water stock could be observed in all three crop rotation systems. The water deficiency increased rapidly from the end of April until the end of May, however, this pace decelerated by June and the reduction in the soil water stock was much smaller. From the end of July, the soil water stock was strongly reduced due to the high evaporation and the increasing water uptake by plants and this state was 
sustained until the end of the season. The largest water deficiency values of the season were also measured in August (324 mm in monoculture., $318 \mathrm{~mm}$ in biculture and 336 $\mathrm{mm}$ in triculture) and in September (329 $\mathrm{mm}$ in mono- and biculture, $318 \mathrm{~mm}$ in triculture).

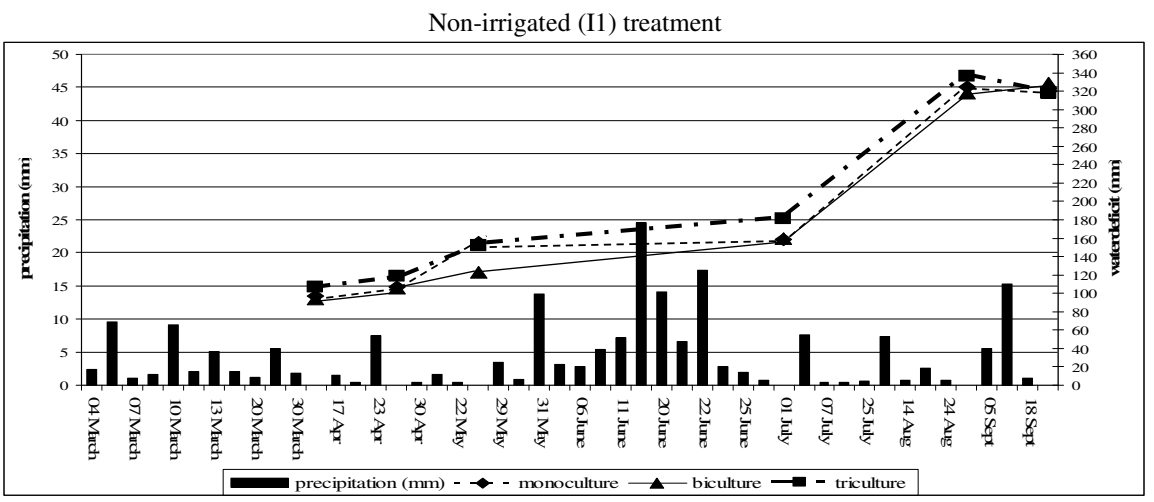

Irrigated (I3) treatment

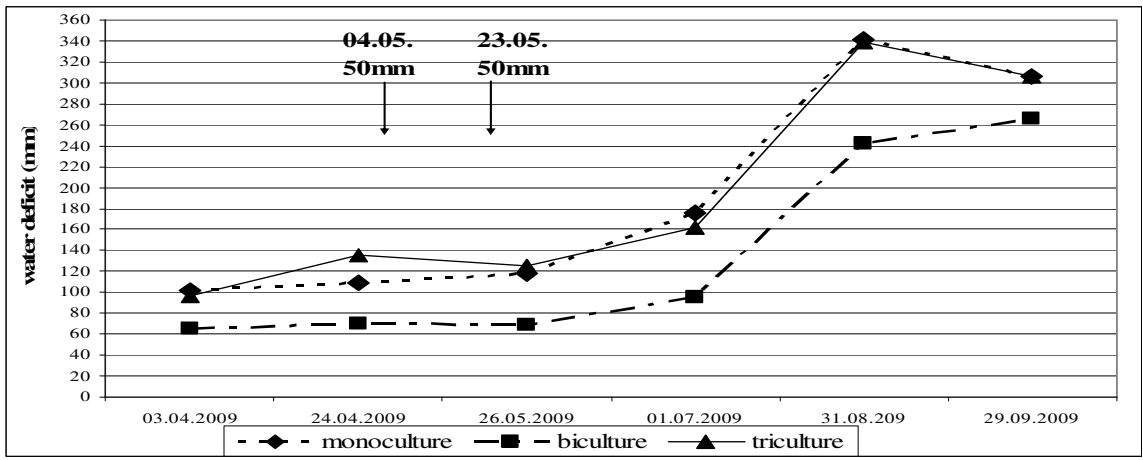

Figure 1. Values of watersupply of different crop-rotation systems and precipitation of croptime (Debrecen -

Látókép, chernozem soil, 2009)

The lines of the diagram in the irrigated treatments during the period between the end of April and the beginning of June show the positive effect of irrigation. While water deficiency suddenly increased in this period in the non-irrigated treatments, there was no large reduction in the irrigated treatments in the soil water stock as a result of irrigation in May, the lines are almost horizontal. The proper timing of irrigation is proved by the fact that the water deficiency values stagnated in this period. The maize stand received the water supply in the growth phase, so it could be wholly utilized for vegetative development.When comparing the yields and the largest water deficiency values of the season in 2007 and 2009, it can be said that the trends of water deficiency values were similar in both years (Table 2). In 2009, the precipitation received in the last minute as regards maize development preceded directly the flowering and grain set, thereby saving the yield, while in 2007, the stand received a higher amount of 
precipitation only late, at mid-August, therefore, it did not have a yield-increasing effect.

In 2009, the largest yield (12295 $\left.\mathrm{kgha}^{-1}\right)$ was obtained in biculture in the non-irrigated treatment $\left(I_{1}\right)$. In the treatment $I_{3}$, yield was higher in all three crop rotation systems as compared to that of the non-irrigated parcels. The largest increment $\left(2952 \mathrm{kgha}^{-1}\right)$ was observed in triculture $\left(\mathrm{I}_{1}: 9913 \mathrm{kgha}^{-1} ; \mathrm{I}_{3}: 12865 \mathrm{kgha}^{-1}\right)$.

Table 2. Effect of agrotechnical factors on the yields of maize (Debrecen - Látókép, 2007, 2009)

\begin{tabular}{|l|c|c|c|c|c|c|}
\hline & \multicolumn{2}{|c|}{ Monoculture } & \multicolumn{2}{c|}{ Biculture } & \multicolumn{2}{c|}{ Triculture } \\
\cline { 2 - 7 } & $\begin{array}{c}\text { Water deficiency } \\
(\mathrm{mm})\end{array}$ & $\begin{array}{c}\text { Yield } \\
\left(\mathrm{kgha}^{-1}\right)\end{array}$ & $\begin{array}{c}\text { Water deficiency } \\
(\mathrm{mm})\end{array}$ & $\begin{array}{c}\text { Yield } \\
\left(\mathrm{kgha}^{-1}\right)\end{array}$ & $\begin{array}{c}\text { Water deficiency } \\
(\mathrm{mm})\end{array}$ & $\begin{array}{c}\text { Yield } \\
\left(\mathrm{kgha}^{-1}\right)\end{array}$ \\
\hline \hline 2007 non-i & 338 & 4316 & 357 & 7706 & 327 & 7062 \\
\hline 2007 irr. & 314 & 8449 & 354 & 10970 & 329 & 10679 \\
\hline $\begin{array}{l}2009 \text { non- } \\
\text { irr. }\end{array}$ & 324 & 9008 & 318 & 12295 & 336 & 9913 \\
\hline 2009 irr. & 341 & 10789 & 242 & 13942 & 339 & 12865 \\
\hline
\end{tabular}

\section{Conclusions}

In two dry years (2007 and 2009), we studied the relationships between the soil water stock and maize yield. The water deficiency values indicate that biculture is the most favourable for maize, the lowest values during the whole season were obtained in this system. The low yields of 2007 can be attributed to the high water deficiency values, while in 2009 the yields were considerably higher in spite of the unfavourable precipitation values. This was due to the high amount of precipitation in June. This precipitation being higher than the 30 -year average had a beneficial effect by satisfying the increasing water demand of maize during flowering and grain set, thereby, it contributed to higher yields. In the case of the irrigated parcels, the water supply in May provided a more uniform water supply for maize during the first half of the season, therefore, the vegetative development was stronger and even higher yields were obtained. The study has proved that by applying the proper agrotechnical elements, the yield-reducing effect of drought can be flexibly mitigated also in dry years.

\section{References}

Birkás M.: 2006. Lehet-e védekezni a klímaszélsőségek ellen? Mezőgazdasági technika, XLVII: 9. $37-39$.

Ceská J. - Hejnák V. - Ernestová Z. - Krizková J.: 2008. The effect of soil drought on photosynthesis and transpiration rates of maize (Zea mays L.). Cereal Research Communications, 36. 823-826.

Hegyi Z. - Pók I. - Berzy T. - Pintér J. - Marton L.C.: 2008. Comparisonof the grain yield and quality potential of maize hybrids in different fao maturity groups. Acta Agronomica Hungarica. 56: 2. 161-167.

Hoffman S. - Debreczeni K. - Hoffman B. - Berecz K.: 2007. Grain yield of wheat and maize as affected by previous crop and seasonal impacts. Cereal Research Communications, 35: 2. 469-72.

Jambrovic A. - Andric L. - Ledencan T. - Zdunic Z.: 2008. Soil and genotype influences on yield and nutritional status of maize hybrid parents. Cereal Research Communications, 36. 1015-1018.

Jolánkai M. - Birkás M.: 2009. Klímaváltozás és növénytermesztés. V. Növénytermesztési Tudományos Nap. Növénytermesztés: Gazdálkodás - Klímaváltozás - Társadalom. Akadémiai Kiadó. 27-32.

Pepó P. - Vad A. - Berényi S.: 2008. Effects of irrigation on yields of maize (Zea mays L.) in different crop rotations. Cereal Research Communications, 36. 735-738.

Várallyay Gy.: 2006. A talaj multifunkcionalitása és szerepe a tájökológiában. II. Magyar Tájökológiai Konferencia Debrecen, 2006. április 7-9. Az előadások és poszterek összefoglalói. 2.

Varga-Haszonits Z. - Varga Z. - Lantos Zs. - Enzsölné Gerencsér E. - Milics G.: 2008. A talajok vízellátottságának hatása a gazdasági növények vízigényének alakulására. Agrokémia és talajtan. 57: 1 


\title{
SHORT-TERM FORECASTS OF WATER STORAGE IN SOIL
}

\author{
Viliam NAGY - Katarína BREZIANSKA
}

Institute of Hydrology, Slovak Academy of Sciences, Račianska 75, 83102 Bratislava, nagy@uh.savba.sk, stehlova@uh.savba.sk

\begin{abstract}
Changes of the precipitation regime are influencing water resources of the Earth and of the regional ecological stability. One of the serious problems to be studied in this context is that of the aeration zone soil water storage change their formation and dynamics, in the agricultural, as well as in the forest ecosystems. The vegetation is mostly supplied by water from the soil aeration zone. Without sufficient water in the aeration zone plants can not grow as expected, in extreme situations they dry out and the agro-ecosystems will not be resilient anymore. It is therefore necessary to know how much water is the soil able to supply to the vegetation plants or in critical situations to endanger their growth or even their existence. One of the possible approaches is to forecast the soil water storage. This can be done by use of the soil water regime mathematical model coupled with a climatic model supplying the necessary input for the first one (meteorological data from the climate change scenarios). Another method could be the one based upon use of the monitored soil profile moisture values. As time series of such monitored data are not too long, their use for such forecasts is limited only for the shortest time period, usually for one third of such period. Year 2010 is the most convenient to give forecast for, as verification of the model can be carried out in a short time. A method has been proposed, enabling on base of the 9 year time series of the soil moisture observations, to elaborate forecast for the 2010 year, and thus to extend the base of data into a 12 year time series. Such data base then can be used for evaluation of the territory resistance against the possible extreme events.
\end{abstract}

Keywords: soil, moisture, climate, water storage,

\section{Introduction}

Aeration zone soil moisture dynamics, as result of the natural elements activity, shows a characteristic course in time and in space (Gusev and Novák, 2007; Gomboš et al., 2009; Birkás et al., 2009). It is denoted in literature as the soil water regime. Soil water regime refers to the whole soil profile in the soil - rock formation layer. So it refers to the set of all soil genetic horizons, including the transition one, up to the groundwater level. Its formation is influenced by several factors. It is not always necessary to investigate the soil profile water regime in its whole depth, particularly if it is very deep. Climate change that impacts upon the meteorological elements is elaborated relatively wide in the world as well as in Slovakia. Much has been done in those impacts upon surface water runoff, its river regime, mainly upon their flood regime (Hlavčová, 2008). But only few authors devoted their attention to these impacts upon the soil water regime change (Velísková et al., 2006; Koós et al., 2009; Šútor and Rodný, 2009). They use mostly soil water regime mathematical models simulating the soil water storage (Štekauerová - Š́tor, 2008). Water storage capacity of Hungarian soils was reported by Várallyay (2005), which is a valuable source for the investigations. Soil moisture measurements, and it importance was investigated by various researchers in the near past (Nagy et al., 2009; Neményi and Milics, 2007; Štekauerová et al., 2009; Šútor et al., 2009). Here the expected climate change is expressed by the input meteorological data developed by the climate change scenarios. These are produced by either coupled or separately used climatic models (GCM models).

To arrive at time courses of the data on soil water resources by the soil moisture measurements at short time intervals, is rather demanding, financially and also as to the necessary instrumentation. However, this method cannot be substituted. For instance, to 
acquire a 10 - year soil moisture time series from several soil profile depths in one locality is considered a fair success.

A method has been proposed, enabling on base of the 9 - year soil moisture observation period, to elaborate forecast for the year 2010, and thus to extend the original data base into the 12 - year one, and to assess vulnerability of the site (locality) even as to occurrence of a dangerous soil moisture event.

\section{Materials and methods}

The Bodíky site experimental base (southwestern Slovakia) has been selected to investigate climate change impacts upon the lowland part soil water regime of this region. Bodíky site is located in a natural environment of the Žitný Ostrov (Rye Island) alluvial forest. This locality belongs to forest ecosystem, mostly with the poplar trees vegetation. Soil of this site is clayey (or sandy- clayey) up to the depth $120 \mathrm{~cm}$ from the surface. From this depth it continues gradually to a sandy character. Its gravel base is located a $150 \mathrm{~cm}$ depth below surface. Soil moisture monitoring at the Bodíky experimental base is in operation since the year 1999, by means of the neutron probe. The moisture is measured at each $10 \mathrm{~cm}$ depth from the surface up to the groundwater level. From these measurements, the water storage in layers 0-30, 0-50, 0-100 and 0-150 $\mathrm{cm}$ under the soil surface were computed.

Based upon the soil water storage observations in the above defined soil layers in 9 years (period 1999 - 2007), the soil storage forecast was elaborated up to the year 2010. Thus this database has been extended to the 12 - year period.

Forecasted values were derived by trend analysis of the mean monthly soil water storage values, for the three consecutive years. For each month were used (plotted) the observed data (mean monthly water storage), and using the best suitable trend (with the highest correlation coefficient), the data series extrapolated by the trend equations up to the year 2010 . Four trends were evaluated: linear, logarithmic, exponential, and power.

\section{Results and discussion}

In Fig.1, there are interpreted graphically the water storages in several soil layers, those measured in the period 1999 - 2007, and the forecasted ones (by the trend analysis) in the period $1999-2010$. As can be seen from this figure, the water storage should rise up to 2010 in all the examined soil layers. For statistical analysis, the cause of such trend is not in centre of the interest, it follows from the previous measurements. This rising trend is more pronounced in the deeper soil layers, so the question arises for the soil physicist, e.g. of the groundwater level influence.

In Fig.2, there are compared mean monthly water storages in the soil layers. Increase of these values, mostly the months of September, October, November, and December take part. From it results water storage in spring should not be endangered because they are crucial for the spring start of vegetation. 

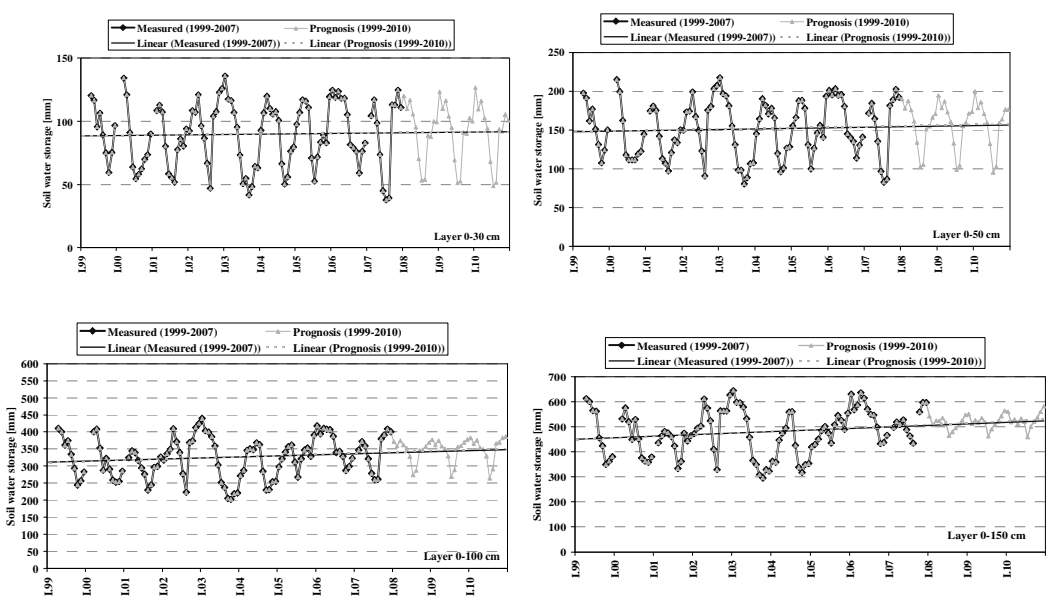

Figure 1. Water storage time course in soil layers 0-30, 0-50, 0-100 a 0-150 cm, calculated from the measured soil moisture values in period 1999-2007 and forecasted water storages in period $1999-2010$, Bodíky locality.
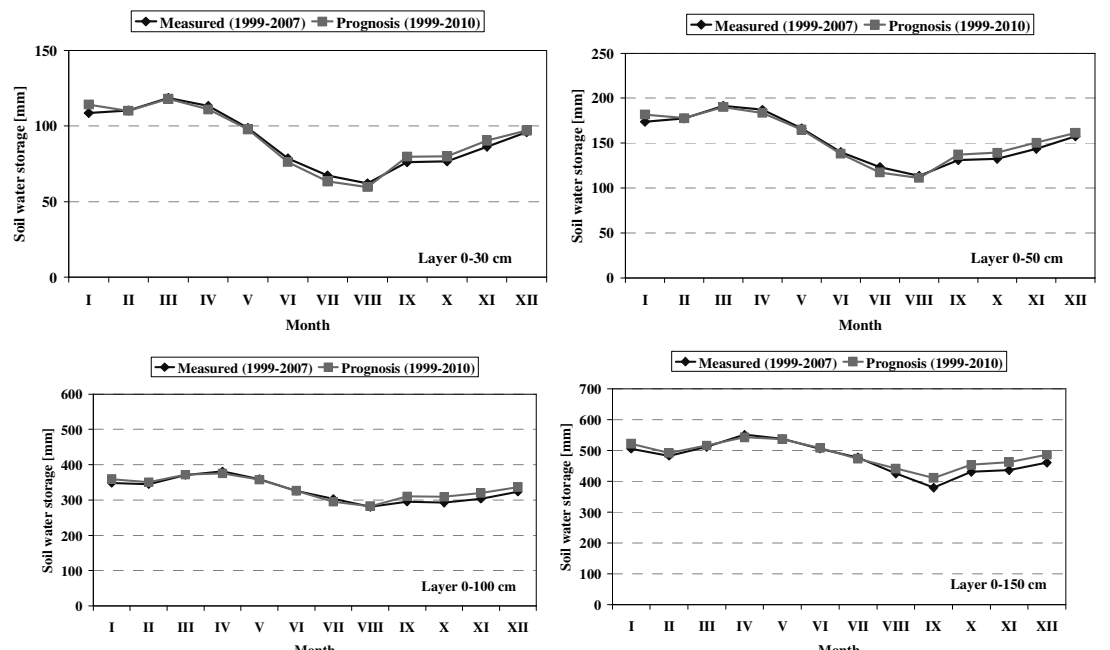

Figure 2. Comparison of the mean monthly values measured (in years 1999-2007) and forecasted (for years 1999-2010) of the water storage in layers $0-30,0-50,0-100$, and 0-150 cm, Bodíky locality. 


\section{Conclusions}

The studied problem of climate change impacts upon the soil water regime is quite complicated, because of lack of usable and long observation on this phenomenon. In Slovakia there is no systematic soil water storage monitoring system which would cover the whole country. The existing local short-term measurements are not sufficient for development of an analytical trend of this phenomenon for the longer time period. On the Bodíky locality, soil moisture monitoring is in operation since 1999 continuously. Using this data, the measurement results were evaluated and the soil water storages calculated in four soil layers, in the years $1999-2007$. These were used for forecasting the soil water storages up to the year 2010. These results, however, are not comparable with those calculated from the input data future meteorological scenarios, but they present a real picture of the present soil water storage development on the experimental locality. Their temporal trends, evaluated from the past observations, shows a rising tendency. These were used to forecast the soil water storages up to the year 2010. The rising tendency can be mainly explained by the fact, that the site is located downstream of the large Danube water structure Gabčíkovo. The alluvial forest in this area is artificially flooded in particular period of the year. In consequence, the vegetation in Bodíky locality should not suffer with the water shortage in the foreseeable future.

\section{Acknowledgements}

The authors would like to thank to projects: VEGA 2/0120/08, and APVT 0271-07.

\section{References}

Birkás M. - Dexter A. - Szemők A.:2009. Tillage-induced soil compaction, as a climate threat increasing stressor. Cereal Research Communications, 37: 379-382.

Gomboš M. - Tall A. - Kandra B.: 2009. Creation of soil cracks as an indicator of soil drought. Cereal Research Communications, 37: 367-370.

Gusev Y. - Novák V.: 2007. Soil water - main water resources for terrestrial ecosystems of the biosphere. Journal Hydrol. Hydromech., 55, 3-15.

Hlavčová K. - Szolgay J. - Kohnová S. - Hlásny T.: 2008. Simulation of hydrological response to the future climate in the Hron river basin. Journal of Hydrol. Hydromech., 56, 163-175.

Koós S. - Ristolainen A. - Farkas C.: 2009. Evaluating the effect of abiotic mechanical stress on spatial distribution of soil hydraulic properties. Cereal Research Communications, 37: 383-386

Nagy V. - Milics G. - Deákvári J. - Rodnỳ M. - Šurda P. - Štekauerová V. - Šútor J. - Fenyvesi L. Neményi M.: 2009. A talaj fajlagos elektromos vezetőképessége és a talajnedvességtartalom közötti összefüggés vizsgálata. 5th Crop Production Science Day, Akadémiai Kiadó, Keszthely, 169-172.

Neményi M. - Milics G.: 2007. Precision agriculture technology and diversity. Cereal Research Communications, Vol. 35, Nr 2, Jun 2007, 829-832, Akadémiai Kiadó, DOI 10.1556/CRC.35.2007.2.166, ISSN 0133-3720

Štekauerová V. - Nagy V. - Š́tor J. - Milics G. - Neményi M.: 2009. Influence of groundwater level on soil water regime of Žitnỳ Ostrov. 5th Crop Production Science Day,Akadémiai Kiadó,Keszthely,197-200.

Štekauerová V - Š́tor J.: 2008. Alternative method to soil water infiltration experiment. Cereal Research Communications, 36, 1471-1474.

Š́tor J. - Rodný M.: 2009. Prognosis of soil drought. Cereal Research Communications, 37, Suppl. 395-398.

Š́tor J. - Štekauerová V. - Nagy V. - Rodnỳ M. - Šurda P. - Milics G. - Neményi M.: 2009. Agricultural ecosystems protection by the soil water regime stabilization. 5th Crop Production Science Day, Akadémiai Kiadó, Keszthely, 209-212.

Várallyay, Gy.: 2005. Water storage capacity of Hungarian soils. (In Hung.) Agrokémia és Talajtan. 54. 5-24.

Velísková Y. - Dulovičová R. - Skalová J.: 2009. Quality and quantity of water resources as stress factor for agri-environment at eastern part of rye island (Slovakia). Cereal Research Communications, 37: 493-496. 


\title{
SIMULATION OF THE WATER AVAILABILITY CHANGES FOR THE PLANT COVER AS A RESULT OF CLIMATE CHANGE
}

\author{
Milan GOMBOঙ̌
}

Institute of Hydrology, Slovak Academy of Sciences, Hollého 42, 07101 Michalovce, e-mail: gombos@uh.savba.sk

Abstract: There are inscribed results of numerical simulation of soil moisture regime during vegetal periods of the years 2010, 2030 and 2075 in climatic station Milhostov at East Slovakian Lowland in rendered paper. Hydrometeorological inputs into the simulations were obtained from the climatic scenario CCCM 2000 applied for normal period 1960-1990. Gained informations of the water regime during the reference years were compared with the normal period. Expected changes of the soil water storage were quantified by using this methodology.

Keywords: climatic change, water availability, water storage

\section{Introduction}

Within the climate change progression it is possible to expect rising of the vulnerability of the water resources. One of the water resources is the soil water. Water stored in the soil is of the great importance because it is the water source for the biosphere. Vulnerability of this water source is manifested by decreasing of the assurance and therefore decreasing of the water availability for the plant cover. (Mati et al., 2008; Šoltész, Baroková, László, 2008) Availability of the water for the plant cover is determined by the interval between field water capacity and treshold point (Tall and Kandra, 2007; Vilček, 2004). Moisture state between treshold and wilting point is possible to define as the state of drought. (Nagy et al., 2007; )The aim of the paper is to quantify the impact of expected climate change on the soil-water storage availability for the plant cover.

\section{Materials and methods}

Impact of climate changes on water storage in the soil has been examined in the locality of Milhostov in East Slovakian Lowland. There is located climatic station in the area of interest. There were worked out climatic scenarios of climate change for inscribed station.

Results from Canadian climatic scenario CCCM 2000 were used in inscribed paper. Outlets from this scenario were prepared on the bases of normal period 1961-1990 for reference years 2010, 2030 and 2075 (Lapin et al., 2003; Stehlová and Skalová, 2009). Gained data were used as input for model FLOCR (Oostindie and Bronswijk, 1992).

There were numerically simulated developments of soil water storage into the depth of $3 \mathrm{~m}$ by $0,1 \mathrm{~m}$ layers. Soil water storage was analyzed with the day time-step into the depth of $1 \mathrm{~m}$. Determining part of the root zone of the field plants occurs in this layer. Simulation was realized for vegetal periods of the years 2010, 2030, 2075 and 1971. Total daily evapotranspiration ETpot of vegetal period of the year 1971 is closest to the long-time average value of ETpot of vegetal periods of 1961-1990. Therefore was 
vegetal period of the year 1971 chosen as a representative for normal period of 19611990.

Total changes of the soil water storage and changes of available water storage for the plant cover was quantified from the gained results. Changes were quantified for vegetal periods during years 2010, 2030 and 2075 with regard to vegetal period of the year 1971.

\section{Results and discussion}

There are inscribed developments of soil-water storages into the depth of $1 \mathrm{~m}$ with a one day time-step for representative year 1971 of a normal period 1961-1990 and for reference years 2010, 2030 and 2075 at the figure 1. Apparent remission of the soil water storage caused by expected climate change is clearly visible at the figure. The biggest changes are manifested during the year 2075 .

There are inscribed average remissions of total water storages during vegetal periods of the years 2010, 2030 and 2075 at the figure 2. Remissions are expressed in percentages with regard to the year 1971. Changes of water storage were analyzed in topsoil layer $(0,0-0,3 \mathrm{~m}>$, in sub-topsoil layer $(0,3-0,5 \mathrm{~m}>$, in bottom soil layer $(0,5-1,0 \mathrm{~m}>$ and in the layer of root zone of the soil profile to the depth of $1 \mathrm{~m}$. The highest decline of the water was identified in topsoil layer. It is possible to expect such a decline with the value of $5 \%$ compared to the normal period on the present. In the year of 2075 it is possible to

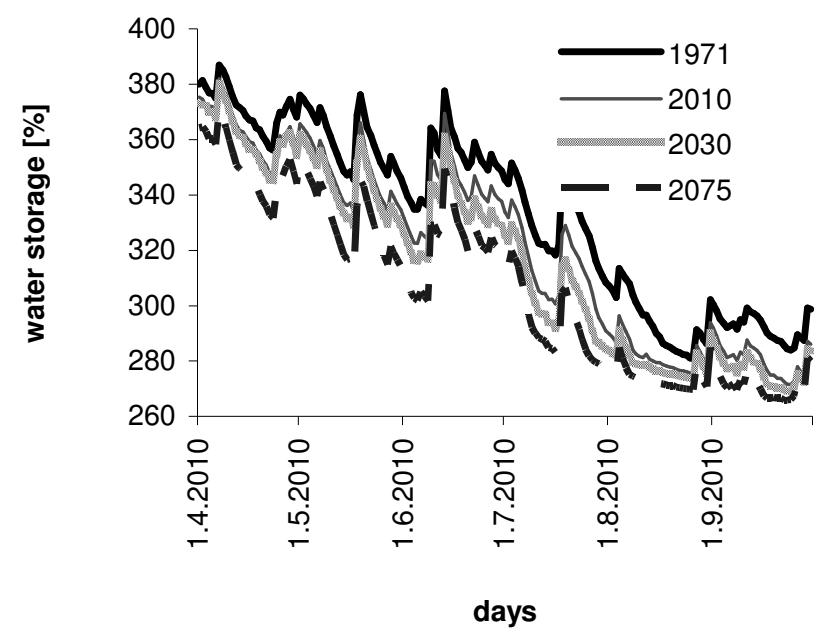

Figure 1. Development of soil water storage into the depth of $1 \mathrm{~m}$ in 1971 and during reference years of 2010 , 2030 and 2075. 


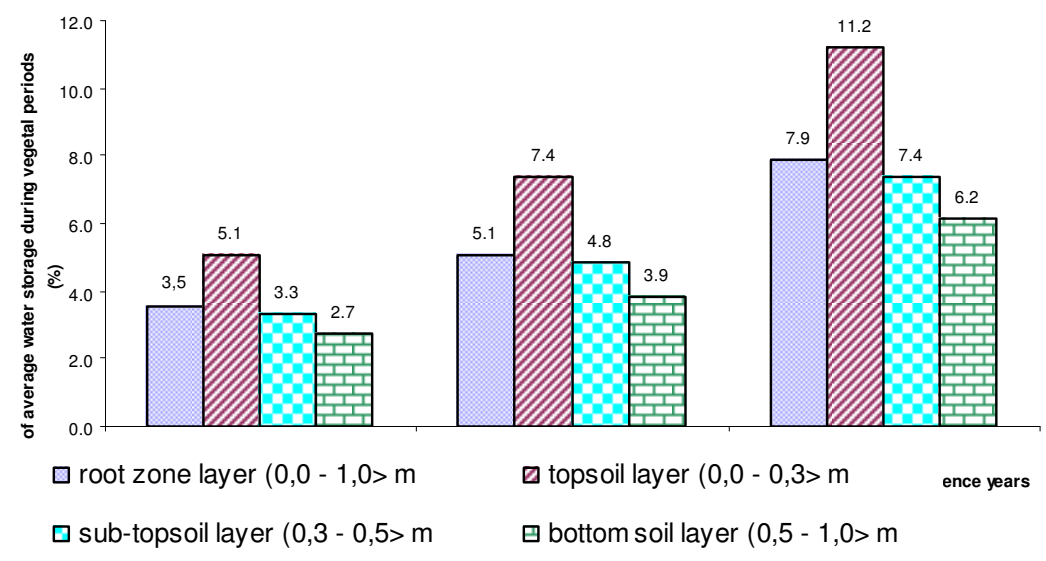

Figure 2. Decline of soil-water storage into the depth of $1 \mathrm{~m}$ during reference years 2010, 2030 and 2075 expressed in (\%) with regard to the year 1971. Decline is quantified for different soil layers.

expect increase of this deficiency up to $11 \%$. Average deficiencies in sub-topsoil layer are on the decline level of whole root zone and rising from $3,5 \%$ (on the present) to $8 \%$ (in 2075).

Impact of expected climate change on soil-water storage in term of water availability for the plant cover is expressing figure 3. Declines of water storages are expressed in light of soil water that is within the interval of utilizable water capacity. Identified average

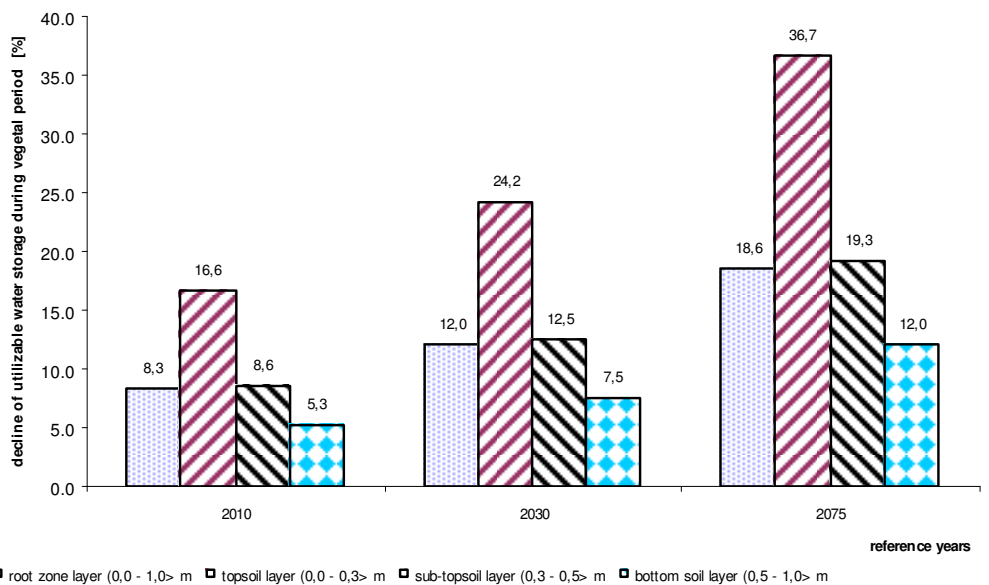

Figure 3. Decline of utilizable soil water storage to the depth of $1 \mathrm{~m}$ in reference years 2010, 2030 and 2075 expressed in (\%) with regard to year 1971. Decline is quantified for different soil layers. 
decline of utilizable water storage during vegetal periods in topsoil layer increases from today's $17 \%$ to $37 \%$ in year 2075. These declines are rising from today's $8 \%$ to $19 \%$ in year 2075 in sub-topsoil layer and a root zone.

\section{Conclusions}

There are inscribed results of numerical simulation of soil moisture regime during vegetal periods of the years 2010, 2030 and 2075 in climatic station Milhostov at East Slovakian Lowland in rendered paper. Hydrometeorological inputs into the simulations were obtained from the climatic scenario CCCM 2000 applied for normal period 19601990. Gained information of the water regime during the reference years were compared with the normal period. Expected changes of the soil water storage were quantified by using this procedure. Normal period is on the basis of selective criteria ETpot represented by vegetal period of the year 1971.

Results clearly indicates that impact of climate change will manifest by decrease of water storage in the interval of available water capacity in examined profile. Average deficiency of water availability into the depth of $1 \mathrm{~m}$ will rise from $8 \%$ to $19 \%$ in the year 2075 in comparison to the year 1971. The highest identified average decline of water storage for vegetal periods are manifested in topsoil layer which are rising from $17 \%$ to $37 \%$ in year 2075 . It will be possible to verify inscribed results on the basis of monitoring of the soil-water storage in examine profile in the year 2010.

\section{Acknowledgement}

The author would like thank for the kind support of the project VEGA 2/0130/09.

\section{References}

Bronswijk, J. J. B.: 1990. Shrinkage geometry of a heavy clay soil at various stresses. Soil Science Society of America Journal 54: 1500-1502.

Lapin, M. - Hlavčová, K. - Petrovič, P.: 2003. Vplyv klimatickej zmeny na hydrologické procesy. Acta Hydrologica Slovaca, 4: 2. 211 - 221

Mati, R. - Kotorová, D. - Pavelková, D. - Kováč, L.: 2008. Kvantifikácia vodoretenčných schopností zóny aerácie pôdy v suchom Poldri Beša. Physics of Soil Water, 17th slovak - czech - polish scientific seminar Slovakia, ÚH SAV, ISBN 978-80-89139-15-6, 6 s.

Nagy, V. - Štekauerová, V. - Neményi, M. - Milics, G. - Koltai, G.: 2007. The role of soil moisture regime in sustainable agriculture in both side of river Danube in 2002 and 2003. Cereal Research Communications, 35: 2. 821-824.

Šoltész, A. - Baroková, D. - László, I.: 2008. Hidrogeológia, Élet a folyók között. In ed. E. Dobos. A Bodrogköz tájhasználati monográfiája. Miskolc, Miskolci Egyetem, ISBN 978 9630642644, 25-38

Stehlová, K. - Skalová, J.: 2009. Soil Water Regime Influenced by Climate Change. In Eds. G. Halasi-Kun. Pollution and Water Resources, Columbia University Seminar Proceedings : Scientific and SocialInstitutional Aspects of Central Europe and USA. Pécs : Hungarian Academy of Sciences, , ISBN 978963-9899-11-7, 259-285.

Tall, A. - Kandra, B.: 2007. Zhodnotenie vodného režimu pôdy s ohl'adom na pôdne sucho. In Acta Hydrologica Slovaca, , roč. 8, no. 1, s. 119-126. ISSN 1335-6291.

Vilček, J.: 2004. Zonálnost' a produkčno-ekonomická charakteristika pol'nohospodárskych pôd Východoslovenskej nížiny; Agriculture, 50, (7-9): 139-146. 


\title{
SOIL MOISTURE MEASUREMENTS COMPARISON OF DIFFERENT TECHNIQUES
}

\author{
Botond SINÓROS-SZABÓ ${ }^{1}-$ József DEÁKVÁRI ${ }^{2}-$ László FENYVESI $^{2}$ \\ ${ }^{1}$ University of Debrecen, Centre for Agricultural Sciences and Engineering, Institute of Research and \\ Development, Böszörményi u. 138. Debrecen, H-4032, Hungary, Tel: + 36 52/508-310. \\ ${ }^{2}$ FVMMI Hungarian Institute of Agricultural Engineering, Tessedik Sámuel u. 4., Gödöllő, H-2100, \\ Hungary, Tel.: + 36 28/511-601, e-mail: deakvari@fvmmi.hu
}

Abstract: State of the soil - especially its water content - is a very important factor in the agro-ecosystem. Soil moisture content plays fundamental role in the life of plants. Without supply of water plants reach the wilting point, where a given agro-ecosystem can not be resilient any longer. Knowledge about soil moisture therefore is mandatory in order to sustain productive plant production. For measuring soil moisture there are several methods. The most reliable is the gravimetric method; however sampling and measurements require time and relatively large workforce. Using special instruments, like the neutron probe requires previously prepared sampling sites as well as continuous calibration. Time domain reflectometry (TDR) method results quick and reliable information however the goodness of soil moisture map depends on the sampling strategy and the density of sampling sites. In this article authors report the measuring and mapping methods for determining soil moisture. At the same time authors compare an on-the-go instrument namely Veris 3100 electrical conductivity measurement device with the conventional soil moisture measurement systems in order to investigate the possibility of application of the instrument for soil moisture measurement.

Keywords: Soil moisture measurement, TDR method, soil electrical conductivity

\section{Introduction}

Soils - as the most complex geo-sphere - has been investigated from different points of view: Várallyay (2007) stated that soils are conditionally renewable natural resources. As a (conditionally) renewable source, soil conditions influence - through plant production - the food chain therefore soils influence the quality of life (Várallyay, 2006). Importance of soil moisture measurement was emphasized by various authors: Soil water regime of agricultural field and forest ecosystems was investigated by (Štekauerová et al., 2006; Nagy et al., 2007; and Š́tor et al., 2009). Measurement techniques of soil moisture and their comparable results were reported earlier by Rajkai and Rydén (1992), Rajkai (1993) and recently by Nagy et al. (2009). Application of GIS softwares for visualization of the measured data was reported by Milics et al. (2006) and Morschhauser and Milics, (2009). From the plant production aspect, role of soil moisture was investigated by Neményi and Milics (2007) and Milics and Neményi (2008).

For soil moisture measurement various methods are available. One of the most commonly used methods is Time Domain Reflectometry (TDR) measurement which provides quick and reliable information about soil moisture. Reliability of the TDR measurements can be ensured by calibration or comparison the measured values with values measured by means of gravimetric method. Correlation between gravimetric and TDR measurement techniques was reported very strong $\left(\mathrm{R}^{2}=0,88\right)$ by Milics et al., (2009). Soil moisture is interdependent with various factors. One of these factors is soil electrical conductivity. In present study authors report the results of comparison of soil moisture content and soil electrical conductivity measured by a special device (Veris Technologies 3100). 


\section{Materials and methods}

In order to be able to collect sufficient amount of data as well as reach spatially well distributed samples a 23.52 ha research area were chosen in a study field belonging to University of West Hungary. Soil samples for gravimetric measurements were collected in 24 locations, soil moisture content measurements by TDR method was carried out in 1364 different locations; on-the-go electrical conductivity measurements provided 13531 data (Fig 1)
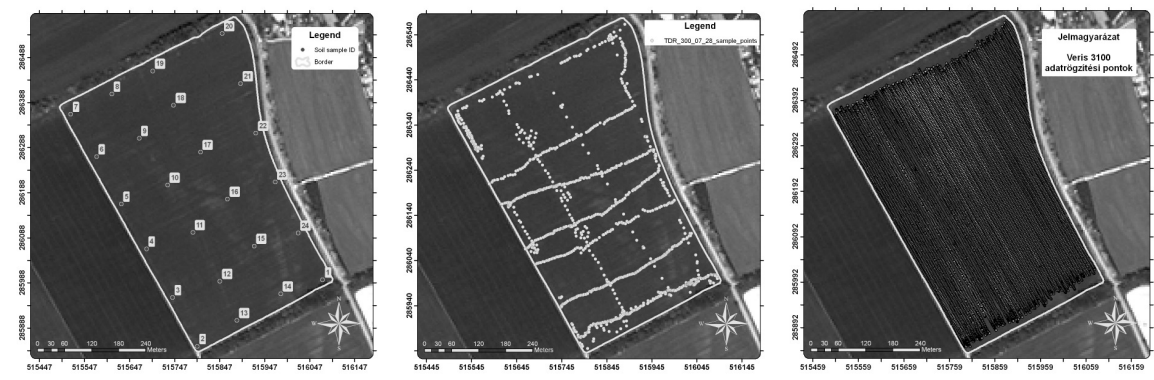

Figure 1. Data collection points (Soil samples /hand/, TDR /hand/, electrical conductivity /on-the-go/.)

Spectrum TDR-300 instrument was equipped with a $20 \mathrm{~cm}$ rod. Sampling was always carried out by giving geographical coordinates to the measurement locations. In case of hand collected data a handheld GPS receiver (Garmin eTrex Vista C), in case of TDR measurements and automatized GPS coordinate was assigned to the measured data. In case of Veris-3100 electrical conductivity measurements GPS coordinates are provided by the system component GPS receiver. Measurements were carried out in $28^{\text {th }}$ of July, 2009 after winter wheat was harvested from the field. Prior to visualization by means of ArcView Geographical Information Software (GIS), data was filtered by means of Grubbs-test for outliers, therefore 1348 TDR and 13485 Veris 3100 measurement points were included in the final dataset.

In order to be able to visually correlate the data, inverse distance weighting interpolation was carried out.

\section{Results and discussion}

Volumetric soil moisture content measured by gravimetric and TDR methods showed a comparable map with soil electrical conductivity map (Fig. 2) Differences in the resolution clearly show that the densest the measurement is, the most reliable map can be interpolated from the dataset. For geostatistical comparison similar output raster size maps could be interpolated, however the reliability of such map could be questioned for a 23.52 hectare area based on only 24 sampling point. 

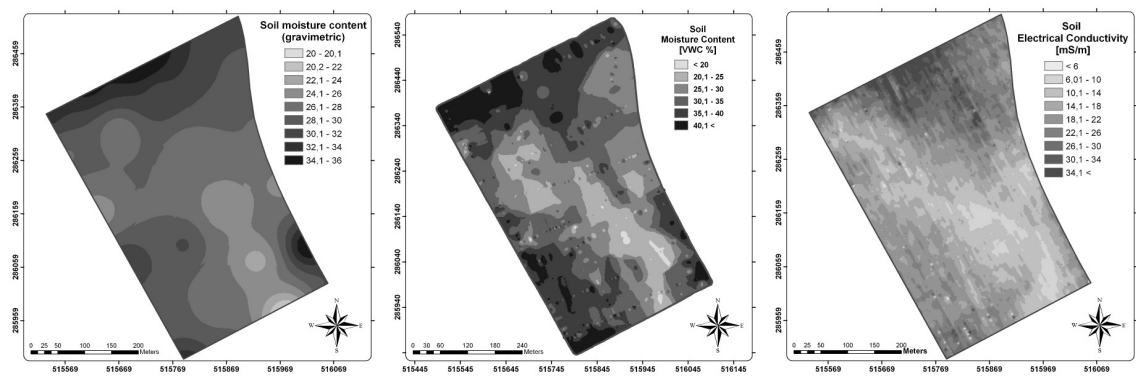

Figure 2. Interpolated soil moisture and electrical conductivity maps.

The interpolated soil moisture map based on the gravimetric measurements (24 sample points) shows only a rough pattern, the soil moisture map based on the dataset collected by means of TDR measurements (1348 sample points) on the other hand can be used as a reliable soil moisture map about the studied field. The interpolated map based on the on-the-go Veris-3100 measurements 13485 sample points can give further description of the pattern of the field. By visual comparison it can be stated that there is correlation between soil moisture and soil electrical conductivity.

\section{Conclusions}

Veris Technologies 3100 electrical conductivity measurements among other important information on the soil can provide reliable data on soil moisture content. For more precise comparison a denser sampling technique for the gravimetric measurements should be developed, however for visualization and decision support for site-specific soil management electrical conductivity mapping can be a usable tool.

\section{Acknowledgements}

Authors would like to thank for the support of FVM-MGI, University of West Hungary, Mosonmagyaróvár and Szent István University, Gödöllö.

\section{References}

Milics G. - Neményi M.: 2008. Precision Agriculture. In: M. Neményi (Ed.): Research Activities of the Institute of Biosystems Engineering (University of West Hungary) Related to Renewable Energies. (Renewable Energy Textbooks, Vol. 5.), NYME-MÉK, Biológiai Rendszerek Müszaki Intézete, Mosonmagyaróvár, 70-94. ISBN 978-963-9883-00-0

Milics G. - Nagy V. - Štekauerová V.: 2006. Application of GIS for evaluating, monitoring and presenting groundwater and soil moisture data. Pollution and Water Resources Columbia University Seminar Proceedings, Vol. XXXVI, New York, USA 69-75.

Milics G. - Nagy, V. - Marek Rodný, M. - Šurda, P. - Štekauerová, V. - Š́tor, J. - Neményi, M.: 2009. Comparison of gravimetric and TDR soil moisture measurement methods from the aspect of site-specific plant production, 17th International Posterday, Bratislava, Conference CD, 391-395 
Morschhauser T. - Milics G.: 2009. Mapping stress in natural and artificial ecosystems. Cereal Research Communications 37:(suppl.) 577-580.

Nagy, V. - Štekauerová, V. - Neményi, M. - Milics, G. - Koltai, G.: 2007. The role of soil moisture regime in sustainable agriculture in both sides of river Danube in 2002 and 2003. Cereal Research Communications, 35: 821-824.

Nagy, V. - Štekauerová, V. - Milics G. - Lichner, L. - Neményi M.: 2008. Harmonisation of different measuring methods of soil moisture used in Žitný Ostrov (SK) and Szigetköz (HU). Cereal Research Communications, 36: 1475-1478.

Neményi M. - Milics G.: 2007. Precision agriculture technology and diversity. Cereal Research Communications, 35: 829-832.

Rajkai K.: 1993. A talajok vízgazdálkodási tulajdonságainak vizsgálati módszerei. In: Búzás I. (ed): Talaj- és agrokémiai vizsgálati módszerkönyv 1. A talaj fizikai, vízgazdálkodási és ásványtani vizsgálata. INDA 4321 Kiadó, Budapest. pp. 115-160.

Rajkai K. - Rydén, B. E.: 1992. Measuring areal soil moisture distribution with TDR method, Geoderma, Vol. 52: $73-85$

Štekauerová, V. - Nagy, V. - Kotorová, D.: 2006 Soil water regime of agricultural field and forest ecosystems. In: Biologia. Vol. 61, Suppl. 19, 2006, S300-S304. ISSN-1335-6372.

Šútor J. - Štekauerová V. - Nagy V. - Rodnỳ M. - Šurda P. - Milics G. - Neményi M.: 2009. Agricultural ecosystems protection by the soil water regime stabilization. 5th Crop Production Science Day, Akadémiai Kiadó, Keszthely, 209-212.

Várallyay, Gy.: 2006. Life quality - soil - food chain. Cereal Research Communications, 34: 335-339.

Várallyay, Gy.: 2007. Soil resilience (Is soil a renewable natural resource?) Cereal Research Communications, 35: $1277-1280$. 


\title{
SOIL MOISTURE MONITORING AS RESILIENCE INDICATOR ON THE DANUBE LOWLANDS
}

\author{
Gábor KOLTAI ${ }^{1}$ - Friderika HEGEDÜS MIKÉNÉ ${ }^{1}$ - Krisztina R. VÉGH ${ }^{2}-$ \\ Tomáš ORFÁNUS ${ }^{3}-$ Kálmán RAJKAI ${ }^{2}$ \\ ${ }^{1}$ Faculty of Agricultural and Food Sciences, University of West Hungary, 9200 Mosonmagyaróvár, Vár 2. \\ Hungary, e-mail: mikehf@mtk.nyme.hu \\ ${ }^{2}$ Soil Science Department, Institute for Soil Science and Agricultural Chemistry of Hungarian Academy of \\ Sciences, 1025 P.O.Box, Budapest, Hungary, e-mail: krajkai@ rissac.hu \\ ${ }^{3}$ Farm Business Analysis Department of Institute of Hydrology, 1355 PO Box 5, Bratislava, 55. Slovakia, e- \\ mail: tomas.orfanus@uh.savba.sk
}

Abstract: In the Danube Lowland in West Hungary and Slovakia the ground water table depth is depending on the water quantity in the riverbed. Water relations of the soil and vegetation systems in the Lowland area are determined primarily by the ground water systems while climate is only secondary. However, the intensive agricultural plant production is controlled both by ground water supply and precipitation as well. Moisture supply for plants can be followed by monitoring actual soil moisture content of the vadose zone. Monitoring of soil moisture dynamism in the vadose zone is used to judge the available soil water storages at 3 sites in the vegetation seasons in 2008 and 2009 years. For estimating of soil resilience at the study sites plant growth model is used to find that ground water table depth, and its rising combinations, which keep the agricultural potential. Monitoring of soil moisture status can immediately indicate changes in soil hydrology caused by either ground water hydrology or local weather. Repeated changes, however, may overcome soil resilience, lead to altered soil environment.

Keywords: monitoring of soil moisture, crop model, soil resilience, soil hydrology, environmental indication

\section{Introduction}

Diversion of the river Danube in 1992 has improved runoff amounts in Mosoni Danube but has decreased the mean runoff in the main riverbed by 10-20\% within the $42 \mathrm{~km}$ long stage between Dunacsúny and Szap localities. Since technological arrangements on the old Danube riverbed have still not been finished to compensate this runoff shrinkage, the ground water level has lowered in substantial part of the area (Deák et al, 2004). Some technological arrangements which were already introduced (dam near Dunakiliti) have positive effect in part of the area, but for the rest of the area the relatively deep old Danube riverbed with low water levels acts rather as drainage then as ground-water supplier. An environmental monitoring system has been functioned in the area influenced by the Danube diversion. Measurement of the soil water content profiles at observation sites in the Danube Lowlands forms a significant part of the monitoring system.

Effects of the ground water depression on capillary supply of the water demand of cultivated lands are evaluated by simulation modeling. Water consumption and the recorded ground water depths of wheat or maize and grass fields, plus a poplar plantation are studied at three observations sites in two consecutive years in the Szigetköz.

\section{Materials and methods}

Ground water table and land use interactions were evaluated for three study sites: Dunasziget (Site1), Dunaremete (Site2) and Ásványráró (Site3). In Site1 ( $\alpha=$ 
$\left.47^{\circ} 55^{\prime} 44^{\prime \prime}, \lambda=17^{\circ} 24^{\prime} 19^{\prime \prime}\right)$ a poplar plantation planted in 2006 is grown with $680 \mathrm{~mm}$ year ${ }^{-1}$ water demand. Site $2\left(\alpha=47^{\circ} 52^{\prime} 44^{\prime \prime}, \lambda=17^{\circ} 27^{\prime} 23^{\prime \prime}\right)$ is a grass field consisting of $20 \%$ short, $60 \%$ tall grass and $20 \%$ legume species. In Site3 $\left(\alpha=47^{\circ} 49^{\prime} 07^{\prime \prime}, \lambda=\right.$ $\left.17^{\circ} 32^{\prime} 15^{\prime \prime}\right)$ winter wheat and maize crops were produced in 2008 and 2009.

At each study site capacitance probe, and neutron probe measurements plus core soil sample collection were made at $0-150 \mathrm{~cm}$ depth in the bilateral cooperation frame between the Hungarian and Slovak Academy of Sciences (Nagy et al, 2007; 2008).

Estimated mean capillary rise flux at the lower depth of the rooting zone was used to calculate the ground water depth of layered soil. For this calculation we used the CAPRISE program by Anlauf et al. (1990). Water potential at the ground water table is zero, and $-1 \mathrm{kPa}$ at the lower boundary of the root zone (Visser, 1966). Rooting depth for plant cover in each study site is given in Table 1. We estimated the monthly water demand for grass lay and for wheat and maize crops according to Vinczeffy (1993) and Sárközy (1989). Water flux of capillary rise was calculated monthly from April to September. The way of its calculation was as follows:

$$
q=(p w d-p r e-d r w s) / d n
$$

where, $q$ is water flux to the root zone $\left(\mathrm{mm} \cdot \mathrm{day}^{-1}\right)$; pwd is monthly plant water demand $(\mathrm{mm})$; pre is precipitation sum of the month $(\mathrm{mm})$; drsw is decrease in rooting zone water storage $(\mathrm{mm})$; $\mathrm{dn}$ is day number. In our case dn equals one month.

Of course the steady state model estimates of ground water table depth are fairly approximate from many reasons, but physically based as shown by (Várallyay, Rajkai, 1989). Soil texture categories of the CAPRISE program were fitted to the soil layers of the study sites on their clay content, field capacity and wilting point values (Table 1). From weather data of the Hungarian Meteorological Service precipitation as water input, air temperature for calculating water demand of grass lay by Vinceffy (1993) was used. Ground water table depths were taken from the database of the Local Nature Protection Agency and the Water Authority.

\section{Results and discussion}

In the region ground water plays decisive role in soil formation processes and in their agricultural utilization (Várallyay, 1980; 1992). However, intensive agricultural use puts even emphasis on the amount and distribution of precipitation as well, as it is shown by the model calculations. The minimum and maximum values of the calculated water flux from the capillary rise to the rooting zone are shown in Table 1.

The measured and modelled ground water depths using the monthly water fluxes in the vegetation period (Table 1) are shown in Figure 1 for Site 1 and Site3.

In Site 1 the model calculated ground water depths for the poplar plantation were 50-100 $\mathrm{cm}$ higher than the recorded levels in April and September of 2008 and 2009. However, in May the calculated and measured ground water depths were almost equal. Poplar prefers wet soil conditions even with periodic inundations, thriving in flood-prone areas. It assumes 150-200 cm ground water depth in spring, and/or surface inflow from the neighbourhood (Mátyás, 1996; Nagy et al, 2007). The ground water depths were deeper in certain periods about $50-100 \mathrm{~cm}$ in last two years than in 1991 the last year before the diversion. At Site1 neutron and capacitance probe data for the $0-100 \mathrm{~cm}$ soil layer were 
statistically differing but even here in the $100-200 \mathrm{~cm}$ layers and all other sites core sample data and moisture meter data were not different.

Table 1. Properties of soil layers, water flux to the root zone, measured and modelled ground water table depths of the sample sites and plant cover

\begin{tabular}{|c|c|c|c|c|c|c|c|}
\hline $\begin{array}{c}\text { Soil } \\
\text { layers } \\
(\mathrm{cm})\end{array}$ & $\begin{array}{c}\theta \text { at } \\
-20 \mathrm{kPa} \\
(\%)\end{array}$ & $\begin{array}{c}\theta \text { at } \\
-1.5 \\
\mathrm{MPa}(\%)\end{array}$ & $\begin{array}{c}\text { Clay } \\
\text { content } \\
(\%)\end{array}$ & Plants & $\begin{array}{c}\text { Water flux to } \\
\text { root zone } \\
(\mathrm{mm} \text { day }\end{array}$
\end{tabular}

At Site2 the grass field's water relations were optimal for pasture and lawn cultivation before diversion of the Danube. However, when the ground water sunk below $180 \mathrm{~cm}$ to the coarse gravelly sand horizon as it happened in 2008 and 2009 (Table 1), there was no capillary water transport up to the root zone. Consequently hay production of grass field here has become more and more weather type dependent. This is why model calculations are not shown in Figure. 1. In a wheat field such as in Site3 in 2008, the amount of water stored in the soil in early springtime has a decisive role in crop development. Wheat crop has two critical water supply periods i.e. shooting and grain filling, while maize has it from the time of floral initiation, during flowering, and to a lesser extent, during grain filling (Sárközy, 1989). Since there was $138 \mathrm{~mm}$ precipitation in July 2008, and $135 \mathrm{~mm}$ in June 2009, there was no water demand from capillary rise. Model calculated and measured ground water depths in Fig. 1 we can establish that Site3 area didn't suffer from water shortage either before or after diversion of the Danube. At this area ground water stays higher than before diversion (see Figure. 1).

\section{Conclusions}

Even a simple steady-state type calculation helps to estimate the ground water depth serving the plant water demand in the layered soil. At Site3 there is no detectable 
change in capillary water supply. However, in Site1 a slight hardly noticeable reduction in capillary water transport can be shown that soil resilience equalizes maintaining the wetland character. In Site 2 the grass meadow character has definitely become weather or precipitation dependent. It is probable, that soil resilience at this site is timely.

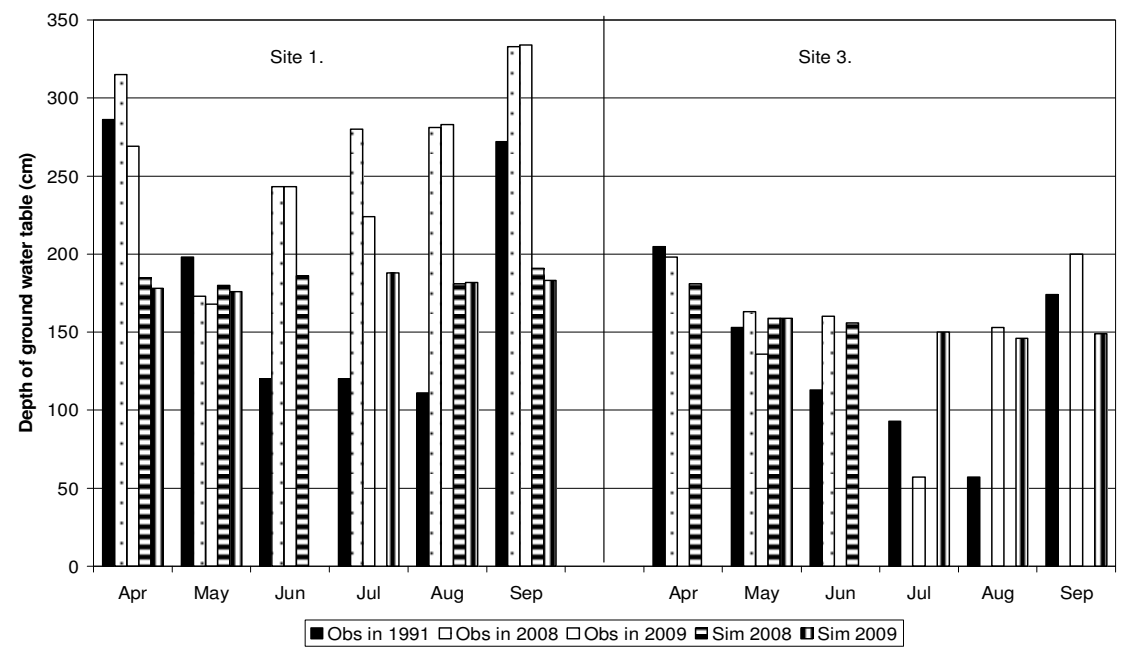

Figure 1. Measured (Obs) and modeled (Sim) ground water depths at study sites

\section{Acknowledgements}

The study was sponsored by the No XVI/10/2/6 project of the Ministry of Environment and Water Management and by Scientific Grant Agency VEGA Project No. 2/0170/09.

\section{References}

Anlauf, K.C. - Kersebaum, L.Y. - Ping, A. - Nuske-Schiiler, J.: 1990. Models for processes in the soil. Catena-Verl., Cremlingen. Germany.

Deák J. - László F. - Liebe P. - Szalai J.: 2004. Conformation of subsurface water supply and state of the ground water depth. Results of Szigetköz Interministerial Monitoring Program, (in Hungarian)

Mátyás Cs. (ed.): 1996. Forestry Ecology. Mezőgazda Kiadó, Budapest (in Hungarian)

Nagy V. - Stekauerova V. - Neményi M. - Milics G. - Koltai G.: 2007. The role of soil moisture regime in sustainable agriculture in both sides of river Danube in 2002 and 2003. Cereal Res. Com. 35: 821-824

Nagy V. - Stekauerova V. - Milics G. - Lichner L. - Neményi M.: 2008. Harmonisation of different measuring metods of soil moisture used in Žitnŷ Ostrov (Sk) and Szigetköz (Hu). Cereal Res. Com. 36: 1475-1478.

Sárközy P. (ed.): 1989. Agriculture in numbers IV. Agroinform-Stagek. Budapest. (in Hungarian)

Várallyay Gy.: 1980. The role of groundwater in the moisture regime of soil and the moisture supply of plants. (In Hungarian) Tudomány és Mezőgazdaság, 18. (5) 22-29.

Várallyay, Gy. - Rajkai K.: 1989. Model for the estimation of water (and solute) transport from the groundwater to overlying soil horizons. Agrokémia és Talajtan 38. 641-656.

Várallyay Gy.: 1992. The soil conditions of the Szigetköz region and its environment, with special regard to their water management. (In Hungarian) Acta Ovariensis 34. (1) 65-73.

Vinczeffy I.: 1993. Pasture and lawn economy. Mezőgazda Kiadó. Budapest. (in Hungarian)

Visser, W. C.: 1966. Progress in the knowledge about the effect of soil moisture content on plant production. Inst. Land Water Management. Res. Wageningen, Techn.Bull. 45. 


\title{
SOIL WATER STORAGE TRESHOLD VALUE IN PROCESSES OF AGRO-ECOSYSTEM DISRUPTION
}

\author{
Július ŠÚTOR ${ }^{1}$ - Štefan REHÁK ${ }^{2}$ - Peter STRADIOT ${ }^{2}-$ Karol KALÚZ $^{3}$ \\ ${ }^{1}$ Institute of Hydrology, Slovak Academy of Sciences, Račianska 75, Bratislava, Slovakia, \\ e-mail: sutor@uh.savba.sk \\ ${ }^{2}$ Water Research Institute, Nábrežie arm. Gen.L.Svobodu 5, Bratislava, Slovakia, \\ ${ }^{3}$ Department of Biometeorology and Hydrology, Horticulture and Landscape Engineering Faculty, Slovak \\ University of Agriculture, Tulipánová 7, Nitra, Slovakia
}

Abstract: The water storage in the aeration zone of soil is a disposable water resource for agro-ecosystems, thus determining their existence. Agro-ecosystems indicate resistance and vulnerability of this water resource under conditions of integral impact of meteorological effects, vegetation cover and ground water table. On the conventional base specific points of the soil moisture retention curve are used in assessment of the vegetation canopy interactions with the soil water supply. Especially the wilting point (WP) defined as insufficient permanent soil moisture at which the vegetation for lack of water wilts away, corresponding to $\mathrm{pF}=4,18$. The point of decreased availability (PDA), describing the soil moisture at which the plants physiological processes are limited by insufficiency of water, corresponding to $\mathrm{pF}=3,3$ and the point of field capacity (FC), related to soil moisture lasting for a relatively longer time in the soil profile, with sufficient soil aeration for plants further development, corresponding to $\mathrm{pF}=2,0$ to 2,7 . It is necessary to mention that the soil water storage in the aeration zone between the FC and the WP (FC-WP) represents an „existence“ water storage interval for vegetation canopy, in the given land locality. This is because the soil water in this interval is the only accessible for plants. This paper deals with the soil water storage interval in which the adaptation of the vegetation cover to change of water storage is flexible up to the WP. Thresholds value of soil water storage was estimated for Žitny ostrov area (South Slovakia) at which an agro-ecosystem disruption corresponds to soil water storage at the WP, respectively when the actual transpiration $\left(\mathrm{T}_{\mathrm{a}}\right)$ equals zero.

Keywords: soil water storage, monitoring of soil moisture, soil moisture regime

\section{Introduction}

Water supply in the soil aeration zone is the water resource for the vegetation cover of soil. This supply has not character of the free water. Plants in order to use it, must have developed root system and such suction pressure that is able to break the bindings between water and soil. Energetic bindings of water and soil are quantified by the soil moisture retention curve (SMRC). Its characteristic points are the field capacity (FC), the point of decreased availability (PDA) and the wilting point (WP). They determine the availability of soil water for canopy root system. The course of the soil water storage in the aeration zone of soil can be obtained by direct monitoring. By comparing these values with characteristic SMRC points we obtain the state of water supply with respect to availability of water for vegetation (Štekauerová and Nagy, 2006). In this framework the wilting point corresponds to the most critical state of the soil water supply. Decrease in the soil water storage below the WP activates the threshold of the destruction processes in the agro-ecosystem. Characteristics of related hydrological processes determined by climatic conditions are often used in evaluation of anthropogenic and climate change impact (Tall, 2007; Koltai et al., 2008). They are the potential evapotranspiration $\left(\mathrm{E}_{\mathrm{to}}\right)$, actual evapotranspiration $\left(\mathrm{E}_{\mathrm{ta}}\right)$, precipitation $(\mathrm{P})$ and their mutual algebraic combinations, i.e. $\left(\mathrm{E}_{\mathrm{to}} / \mathrm{E}_{\mathrm{ta}}\right),\left(\mathrm{E}_{\mathrm{to}}-\mathrm{E}_{\mathrm{ta}}\right)$ and $\left(\mathrm{P} / \mathrm{E}_{\mathrm{to}}\right)$. Threshold value in processes of agro-ecosystem disruption corresponds to the relative evapotranspiration $\left(\mathrm{E}_{\mathrm{r}}\right)=\mathrm{E}_{\mathrm{to}} / \mathrm{E}_{\mathrm{ta}}$ under soil moisture content corresponding to the wilting point. 
While the soil moisture content at the WP is agreed and corresponding to $\mathrm{pF}=4,18$ (convention), values of $\mathrm{E}_{\mathrm{r}}$ are changing according to the type of vegetation in the agroecosystem (Kandra and Gomboš, 2008; Várallyay, 2008).

In this study both approaches for quantification of the agro-ecosystem disruption threshold value are compared at location Trstená na Ostrove (Žitný ostrov).

\section{Materials and methods}

The soil moisture content in the aeration zone of soil was vertically monitored in $10 \mathrm{~cm}$ discrepancy with the help of the direct monitoring from the surface to the depth $100 \mathrm{~cm}$. During the organized series of observations in the period 1988-1994, soil moisture regime datasets were obtained for particular soil layers by two measurement methods, i.e. the gravimetric method, and the TDR method (Nagy and Igaz, 2009). Then the soil water storage was determined for the $100 \mathrm{~cm}$ soil horizon. The soil type at the studied location was classified as loam (according to the USDA classification system). Alongside the soil moisture monitoring the ground water table depth was measured resulting in max-min interval $(361 \mathrm{~cm}-226 \mathrm{~cm})$ and the mean value of $294 \mathrm{~cm}$. Simultaneously there were worked-out the soil hydrophysical, vegetation, meteorological, and other characteristics in order to use them as inputs to the soil water regime model GLOBAL. In 1996 vegetation period the Zea mays was cultivated here.

\section{Results and discussion}

Set of measured soil moisture contents in the $100 \mathrm{~cm}$ soil profile at Trstená na Ostrove location is on Figure 1. The wilting point evaluated from soil moisture retention curve reaches the value of $17,04 \%$ volumetric water content.

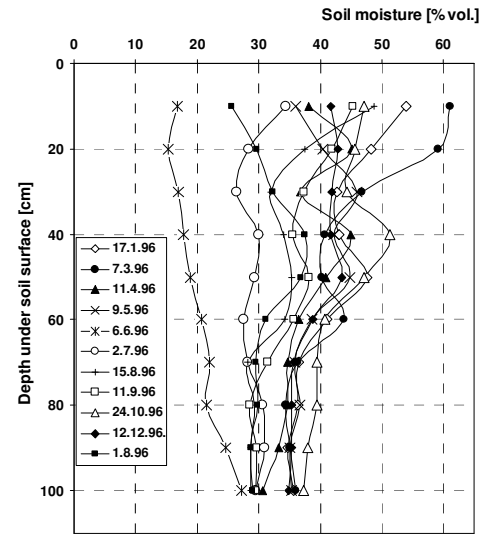

Figure 1. Measured soil moisture content for the $100 \mathrm{~cm}$ aeration zone in the monitoring period 17.1.-12.12. 1996. 
Measured values of soil moisture $\theta=\mathrm{F}(\mathrm{z})$ (Fig.1) were processed for average monthly soil water storage in the aeration zone and for particular time horizons of monitoring $\mathrm{Wp}_{\text {-mon }}=\mathrm{F}(\mathrm{t})$. Results are presented in Figure 2.

The soil aeration zone water balance and its particular elements i.e. $E_{t o}, E_{t a}, E_{r}$ were obtained by numerical simulation on the mathematical model GLOBAL.

Average monthly values of the soil water storage were also obtained by numerical simulation $\mathrm{Wp}_{\text {-mod }}$ and presented on Figure 2 together with the soil water storage $\mathrm{Wp}_{\text {-mon }}$ resulting from the direct monitoring techniques.

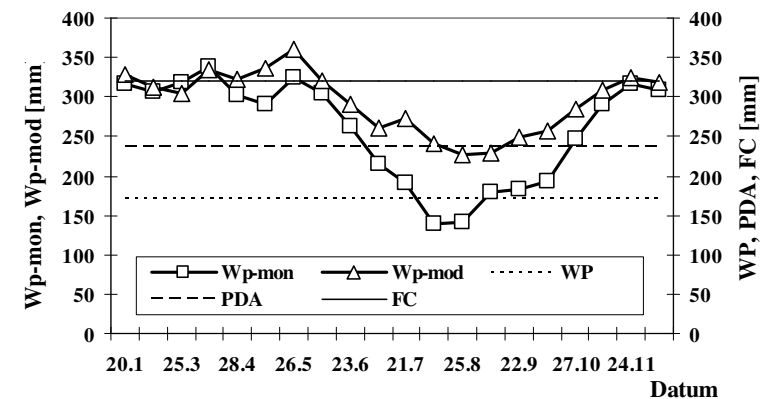

Figure 2. Monitored and modeled soil water storage and its relation to hydrolimits (WP, PDA, FC) for 100 cm aeration zone of soil in location Trstená na Ostrove 1996.

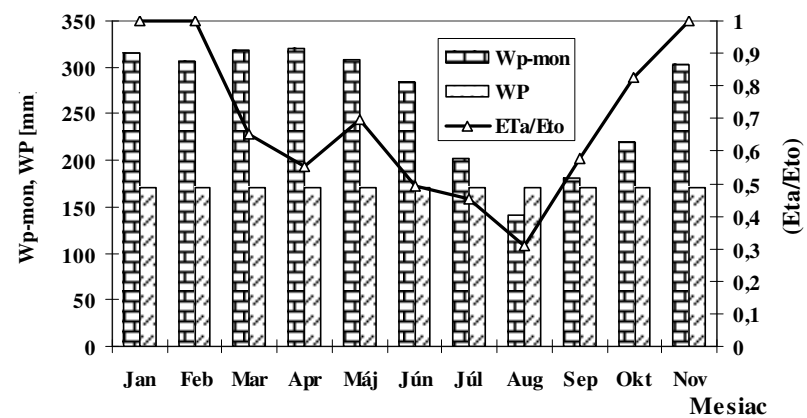

Figure 3. Average monthly water supply in aeration zone $\mathrm{Wp}_{\mathrm{p} \text {-mon }}$ and its influence on course of average monthly relative evapotranspiration $\left(\mathrm{E}_{\mathrm{ta}} / \mathrm{E}_{\mathrm{to}}\right)$ with respect to wilting point.

On the Figure 3 it is shown, that the dependence of relative evapotranspiration $\mathrm{E}_{\mathrm{r}}=$ $\left(\mathrm{E}_{\mathrm{ta}} / \mathrm{E}_{\mathrm{to}}\right)$ copies the course of the soil water storage in the aeration zone of soil. In agrosystem the optimal state of the soil water supply is when $E_{r}=1$. It happens in the beginning and at the end of the year. When we compare monitored courses of water storage $\mathrm{Wp}_{\text {-mon }}$ with the Figure 2 we can see that:

In the period from March up to half of June, the values of $E_{r}$ are gradually decreasing to the value of $E_{r}=0,6$. This decrease in the soil water storage is in the interval of hydrolimits FC and PDA (see Figure 2). From the second half of June up to hydrolimit 
WP the value of $E_{r}$ is gradually decreasing to value 5. Furthermore the $E_{r}$ value continues decreasing below the threshold of destruction of agro-ecosystem up to turning point $\mathrm{E}_{\mathrm{r}}=3,2$. Moreover the $\mathrm{E}_{\mathrm{r}}$ is increasing due to increase in the soil water storage caused by the autumn precipitations. Based on the above mentioned facts the threshold value of the agro-ecosystem destruction fully corresponds with the soil water storage status and the critical amount of soil water related to the WP, respectively to the value of relative evapotranspiration $E_{r}=3,2$. This value is specified to vegetation cover formed by maize.

\section{Conclusions}

The existence of agro-ecosystem is limited by the state of soil water supply. It is possible to evaluate the vegetation canopy interaction with this water supply either from the aspect of the soil water contents corresponding to the hydrolimits of field capacity, point of decreased availability and wilting point, furthermore with the help of course of relative evapotranspiration $\mathrm{Er}=($ Eta/Eto $)$ specific for the vegetation canopy in given agro-ecosystem. Both approaches were applied in the southern Slovakia location Trstená na Ostrove (Žitný ostrov) for climatological conditions in the year 1996. Monitored course of soil water storage was quantified with respect to soil water contents corresponding to hydrolimits FC, PDA and WP. Decrease in the soil water storage to the value of WP in August 1996 is considered as threshold of nonsustainability in the existence of agro-ecosystem, i.e. start of its destruction. Simultaneously course of relative evapotranspiration $E_{r}=\left(E_{t a} / E_{t o}\right)$ was used, where particular elements of water balance $\mathrm{E}_{\mathrm{ta}}$ and $\mathrm{E}_{\mathrm{to}}$ were obtained by numerical simulation on mathematical model. For the agro-ecosystem with the maize canopy the disruption threshold value was estimated as $\mathrm{E}_{\mathrm{r}}=3,2$.

\section{Acknowledgements}

This work was supported by Science and Technology Assistance Agency No. APVV 0271-07 and Grand Agency VEGA (Project No.2/0120/08 and No. 1/319/09)

\section{References}

Kandra B. - Gomboš M.: 2008. Influence of Climatic Elements on the Water Regime in a Soil Profile. In: VII. Alps-Adria Scientific Workshop, Stara Lesna, Slovakia. 1187-1190.

Koltai G. - Milics G. - Neményi M. - Nagy V. - Rajkai K.: 2008. Plant Water Supply of Layered Alluvial Soils Under Different Water Conditions. In: VII. Alps-Adria Scientific Workshop Stara Lesna, Slovakia. $167-170$.

Nagy V. - Igaz D.: 2009. Use of the Gravimetric and TDR Methods for Characterizing Soil Water Storage Stress for the Vegetation. In: VIII. Alps-Adria Scientific Workshop, Neum, Bosnia-Herzegovina. 481484.

Stehlová K. - Štekauerová V.: 2008. Prognosis of Hydrological Balance Members in the Žitný Ostrov Region. In: VII. Alps-Adria Scientific Workshop, StaraLesna, Slovakia. 1451-1454.

Stekauerova V. - Nagy V.: 2006. Course of Soil Layer Water Content in Agricultural Cultivated soil During Years 1999 and 2000. Cereal Research Communications, 34: 1. 287-290.

Tall A.: 2007. Impact of Canopy on the Water Storage Dynamics in Soil. Cereal Research Communications, 35: 2. 1185-1188.

Várallyay G.: 2008. Extreme soil moisture regime as limiting factor of the plants water uptake. In: VII. AlpsAdria Scientific Workshop, Stara Lesna, Slovakia. 3-6 


\title{
STREAM REHABILITATION
}

\section{Use and restoration of natural resilience and resistance capacity of freshwater ecosystems in agricultural land}

\author{
Peter HALAJ ${ }^{1}$ - Dušan IGAZ ${ }^{2}$ - Ján HORÁK ${ }^{2}-$ Anna BÁREKOVÁ ${ }^{3}-$ Lubǒ̌ JURÍK $^{1}$ \\ ${ }^{1}$ Department of Landscape Engineering, Faculty of Horticulture and of Landscape Engineering, Slovak \\ Agricultural University in Nitra, Hospodarska 7, 94976 Nitra, e-mail: peter.halaj@uniag.sk \\ ${ }^{2}$ Department of Biometeorolgy and Hydrology, Faculty of Horticulture and of Landscape Engineering, \\ Slovak Agricultural University in Nitra \\ ${ }^{3}$ Department of Landscape Planning and Land Consolidation, Faculty of Horticulture and of Landscape \\ Engineering, Slovak Agricultural University in Nitra
}

\begin{abstract}
Human impacts of aquatic ecosystems causes that surface waters suffer significantly from hydromorphological and hydrological alterations, disconnection and changes of adjacent floodplains, alterations of surrounding infrastructure that impact water bodies status and therefore need to be addressed in future. Land use in basin of agricultural streams exhibited high loads of sediments and surface runoff that affect stream water quality. It leads to collapse of agricultural stream biota and permanent eutrophication from nutrient inputs. It represents common conditions that, once reached, make difficult to restore the integrity of freshwater ecosystems. The article presents an identification and analysis of impact level of abiotic factors on agricultural streams. Authors summarize the principles and methods of channel-floodplain geosystem restoration that enable to approach to the state of dynamic stability as a basic assumption for increasing of the ,absorbing capacity” of the freshwater ecosystems. They describe the principles of good management practices (GMPs) for agricultural environment where a pristine or minimally disturbed reference conditions can not be established to secure the sustainability of good ecological state of the streams.
\end{abstract}

Keywords: stream rehabilitation, channel morphology, agricultural land use

\section{Introduction}

The continuing anthropogenic stressors to the streams reduce the natural resilience and resistance of the freshwater ecosystems that enables them to recover from certain levels of perturbation. In many systems, the changes brought about through human activities have significantly altered the physical habitat and ecological functioning of the natural systems (Giller, 2005). Although some of the antrophogenic alterations provide important benefits for the human population, they often significantly degrade elements of freshwater ecosystems (i.e. outlets of soil drainage structures, flow regulation). Due to climate and land use changes as well as stream channel modification we may summarize the key impact items that on stream ecosystem: climate change-induced hydrologic alteration manifested by changes in stream discharge regime, channel geomorphological changes due to channel modification and excessive sediment inflow, riparian buffer reduction, floodplain and land use changes. Successful sustainable rehabilitation of stream is depending on identification and understanding of the key processes and anthropogenic induced changes that enable to determinate an appropriate longitudinal and lateral stream structure including stream habitat improvements at different scales. 


\section{Materials and methods}

Our study was undertaken in the $9.45 \mathrm{~km}^{2}$ Bocegaj creek subwatershed in the southeastern part of Slovakia located within cadastre of Zirany village. We analyzed the $1.994 \mathrm{~km}$ long stream channel that has been completely modified to trapezoidal cross section with fortified bed with concrete prefabs at seventieth. For watershed spatial analysis we used aerial photos, cadastre and topographic maps processed by software Terrain Tools ver. 4.162. A software HEC-RAS ver. 4.0 was applied for calculations of hydraulic parameters of stream channel and floodplain areas. The terrain survey data have added to complete the complex view on researched stream ecosystem.

\section{Results and discussion}

For hydrological impact assessment we evaluated long-term variability of the daily discharges of Bocegaj Creek in Kolinany profile in period 1973-1994. We analyze long-term flow average $\left(Q_{a}\right)$, and monthly minimum average flows $\left(Q_{\min }\right)$. Figure 1 shows clear decreasing of $\mathrm{Q}_{\min }$ flow that is measure of minimal discharge that is limited factor for biota survival. Annual long-term flow average $Q_{a}=0,043 \mathrm{~m}^{3} \cdot \mathrm{s}^{-1}$ decreased in analyzed period (1974-1993) to $\mathrm{Q}_{\mathrm{a}, 1974-1993}=0,028 \mathrm{~m}^{3} \cdot \mathrm{s}^{-1}$. Also there exists a trend of increasing of number of days with discharge less than biological discharge $\mathrm{Q}_{330 \mathrm{~d}}=0,005$ $\mathrm{m}^{3} \cdot \mathrm{s}^{-1}$ when 72 days was in 1974 and 107 days was in 1992.

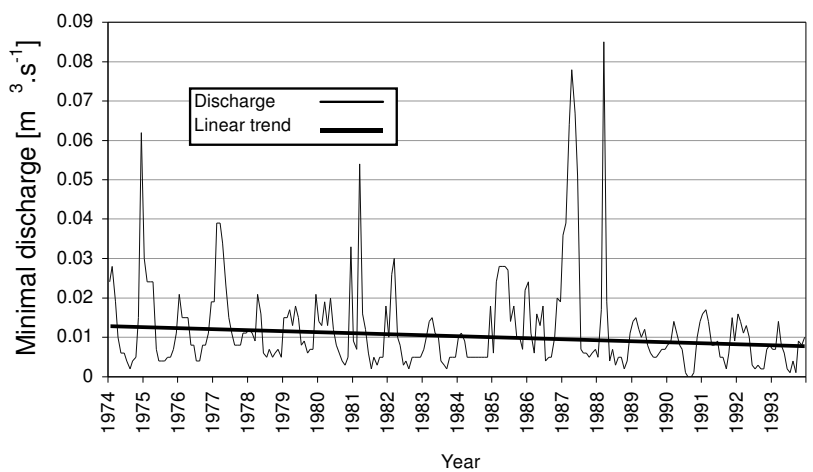

Figure 1. Course of monthly minimal discharges Qmin,month, 1974-1993 and linear trend in Bocegaj Creek for Kolinany gauge in period 1974-1993.

Geomorphological parameters of the recent and original channel state of Bocegaj Creek were analyzed on base of plan view and longitudinal profile drawings of project documentation from 1970 and field geodetic measurements. The hydraulic parameters of the creek's channel calculated by software HEC-RAS ver. 4.0 due to channel modification showed substantial change in channel capacity $\left(\Delta \mathrm{Q}=+3.89 \mathrm{~m}^{3} \cdot \mathrm{s}^{-1}\right.$, i.e. +49 $\%$ ). Stream channel plan view changes as result of sinuosity decreasing (from $\mathrm{Si}=1.21$ to $\mathrm{Si}=1$ ) evoked change of instream accumulated water volume for bankfull discharge of natural channel $\mathrm{Q}_{\text {Bankfull }}=\mathrm{Q}_{4 \text { year }}\left(\Delta \mathrm{V}=-4845 \mathrm{~m}^{-3}\right.$, i.e. $\left.-21 \%\right)$. Analysis of cadastral 
maps and recent aerial photos showed substantial decreasing of riparian vegetation (RV) area $\left(\Delta \mathrm{A}=-12660 \mathrm{~m}^{2}\right)$. Floodplain function change are documented by decreasing of inundation area for $\mathrm{Q}_{20 \text { year }}$ discharge from historical to recent modified state of stream channel $\left(\Delta \mathrm{A}=-74500 \mathrm{~m}^{2}\right)$. Land use changes dynamics represents area balance in cadastre of Zirany for period 1962 - 2002 with substantial increasing of urbanized areas from $0.359 \mathrm{~km}^{2}$ in 1962 to $1.02 \mathrm{~km}^{2}$ in 2002 (Huska et al., 2002). Detailed analysis of agricultural land structure showed $60 \%$ decreasing of grassland that is mainly located next to stream at flood-prone area. On base of field survey and performed analysis we generalized obtained results to identify the key disturbance, symptoms and describe appropriate rehabilitation measures in stream and riparian zones (table 1).

Table 1. Key disturbance, symptoms and appropriate rehabilitation measures in stream and riparian zones

\begin{tabular}{|c|c|c|}
\hline Disturbance and symptoms & Proposed rehabilitation measures & References \\
\hline $\begin{array}{l}\text { Runoff regime alteration: } \\
\text { - increased frequency of low flows } \\
\text { - increased magnitude of peak flow } \\
\text { - decreased groundwater recharge }\end{array}$ & $\begin{array}{l}\text { Instream structures, dead branch } \\
\text { restoration, soil drainage system } \\
\text { modifications, wetland } \\
\text { restoration, small reservoir } \\
\text { building, low flow management, } \\
\text { RV restoration, floodplain land } \\
\text { use changes }\end{array}$ & $\begin{array}{l}\text { Halaj, 2004; } \\
\text { Lake, } 2000\end{array}$ \\
\hline $\begin{array}{l}\text { Hydraulics alteration: } \\
\text { - decreased hydraulic diversity } \\
\text { - water flow acceleration }\end{array}$ & $\begin{array}{l}\text { Channel restoration, instream } \\
\text { structures, habitat reconstruction }\end{array}$ & $\begin{array}{l}\text { Halaj, 2004; } \\
\text { Holčík et al., } 2001\end{array}$ \\
\hline $\begin{array}{l}\text { Water quality decreasing: } \\
\text { - increased contaminant loads } \\
\text { - decreasing of self-cleaning process } \\
\text { intensity } \\
\text { - low dissolved } \mathrm{O}_{2} \text { concentration } \\
\text { - high level of suspended solids }\end{array}$ & $\begin{array}{l}\text { Riparian and grass buffer zone } \\
\text { reconstruction, wetlands } \\
\text { restoration, instream structures, } \\
\text { RV restoration, detention basins } \\
\text { construction, TMDL practices }\end{array}$ & $\begin{array}{l}\text { Halaj, 2004; } \\
\text { USEPA, } 1999\end{array}$ \\
\hline $\begin{array}{l}\text { Geomorphologic alteration: } \\
\text { - simplified channel form } \\
\text { - habitat simplification } \\
\text { - suspended sediment and bed-load } \\
\text { regime changes }\end{array}$ & $\begin{array}{l}\text { Channel and riparian maintenance } \\
\text { flow (CRMF), instream structure, } \\
\text { microhabitat reconstruction, } \\
\text { channel restoration }\end{array}$ & $\begin{array}{l}\text { Hill et al., 1991; } \\
\text { Macura, } 2000\end{array}$ \\
\hline $\begin{array}{l}\text { Floodplain modifications: } \\
\text { - land use and land cover changes }\end{array}$ & $\begin{array}{l}\text { Channel capacity decreasing, } \\
\text { CRMF }\end{array}$ & $\begin{array}{l}\text { Hill et al., } 1991 \\
\text { Muchova et al., } 2009 \\
\end{array}$ \\
\hline $\begin{array}{l}\text { Riparian vegetation alteration (RV): } \\
\text { - decreased eroded soil and nutrient } \\
\text { retention } \\
\text { - reduction, altered patterns } \\
\text { - quality of aquatic and terrestrial } \\
\text { habitat }\end{array}$ & $\begin{array}{l}\text { RV restoration, grass buffer zone } \\
\text { restoration }\end{array}$ & $\begin{array}{l}\text { Johnson, 2004; } \\
\text { Halaj, 2004; } \\
\text { Muchova et al., } 2009\end{array}$ \\
\hline $\begin{array}{l}\text { Ecological disturbances: } \\
\text { - decreased biodiversity } \\
\text { - altered patterns of nutrient and energy } \\
\text { cycling } \\
\text { - loss of hyporheic interstitial zone }\end{array}$ & $\begin{array}{l}\text { Low flow management, CRMF, } \\
\text { RV restoration, fixed fortification } \\
\text { removing, bed substrate } \\
\text { restoration, TMDL practices }\end{array}$ & $\begin{array}{l}\text { Hill et al., 1991; } \\
\text { Halaj, 2004; } \\
\text { USEPA, } 1999\end{array}$ \\
\hline
\end{tabular}

To achieve the goals of stream rehabilitation the good management practices should be applied at floodplain and watershed as well. The concept of Total Maximum Daily Load (TMDL) includes plans for rehabilitation of water bodies in order to provide good water quality (USEPA, 1999). TMDL represents assessment of maximal daily amount of polluting substances of the polluter that water body can receive without disturbing water

301 DOI: $10.1556 /$ Novenyterm.59.2010.Suppl.3 
quality standards. For pollutant budget estimation may be used export coefficient model (Lin, 2004). Thermal Load Management (TLM) approach maintains a optimal thermal regime of the stream that meets requirements of dominant fauna species. The goal may be, inter alia, achieved by optimal shading of water level by riparian vegetation (Johnson, 2004) Channel and riparian maintenance flow (CRMF) provide channel capacity maintenance, flushes of accumulated suspended sediments at gravel bar and riffle habitats, scouring accumulated sediments of pool habitats. Overbank flow by regulated inundation at floodplain provides lateral floodplain and riparian connectivity, floodplain maintenance and nutrient deposition, recruitment of organic material and woody debris (Hill et al., 1991).

\section{Conclusions}

Water Framework Directive requires (WFD) "good quality" for surface waters i.e. low level of changes as a result of human activities. Good status has been defined by biological, hydro-morphological and physical-chemical quality elements including integral approach in their assessments. Implementation of WFD requires analysis of current state of freshwater water ecosystem and human activities impact assessment that is necessary for integral water management application and appropriate measures design for aquatic and terrestrial zones of stream ecosystem.

\section{Acknowledgements}

The work was supported by the Research Support Scheme of the VEGA no. 1/0601/09, $1 / 0319 / 09$, no. $1 / 0624 / 09$, no. 1/0702/08, no. 1/0675/08 and by Slovak Research and Development Agency - APVV no. 0271-07.

\section{References}

Giller, P. S.: 2005. River restoration: seeking standards. Editors introduction. Journal of Appl. Ec., 42: 201207.

Halaj, P.: 2004. Stream rehabilitation. SAU, Nitra. 200. ISBN 80-8069-424-9. (in slovak)

Halaj, P. - Bárek, V. - Igaz, D.: 2005. Assessment of of geomorphological changes effect on level of flood control of surroundings areas next to modified agricultural streams. In: Proceedings of international Conference - Hydrological Days: hydrology and integrated management of water resources. Bratislava, SHMÚ 659-668. ISBN 80-88907-53-5. (in slovak)

Hill, M.T. - Platts, W.S. - Beschta, R.L.: 1991. Ecological and geomorphological concepts for instream and out-of-channel flow requirements. Rivers. 2(3): 198-210.

Holčik, J. - Macura, V.: 2001. Some problems with the interpretation of the impact of stream regulations upon the fish communities. Ekológia, Bratislava, 20: 423-434.

Húska, D. - Jureková, Z. - Jurik, L. - Ratajová, A.: 2002. Development of a Healthy Landscape. In: Proceedings of international Conference European Health and Social Welfare Policies. Évora, Portugal

Lake, P.S.: 2000. Ecological effects of perturbation by drought in flowing waters. Freshwater Biology 48, 1161-1172.

Lin, J. P.: 2004. Review of published export coefficient and event mean concentration (EMC) data, WRAP Technical Notes Collection (ERDC TN-WRAP-04-3), USA ERDC, Vicksburg.

Johnson, S.L.: 2004. Factors influencing stream temperatures in small streams: substrate effects and a shading experiment. Canadian Journal of Fisheries and Aquatic Sciences 61. 913-923.

Macura, V.: 2000. Discharge and channel parameters effect on aquatic stream zone. Acta horticultutrae et Regiotecturae. 3, special issue, 42-46. (in slovak)

Muchová , Z. et al.: 2009. Methodological design standards of land consolidation. SAU, Nitra. 397., ISBN 978-8-552-0267-9

USEPA: 1999. Protocol for developing nutrient TMDL's. EPA 841-B-99-007. Office of Water (4503F) United States Environmental Protection Agency, Washington, DC. 135. 


\section{SUGGESTED PRACTICES FOR USED THERMAL BATHING WATER DISPOSAL}

Gabriella HANCZ ${ }^{1}-$ Csaba ARADI $^{2}$

${ }^{1}$ Department of Civil Engineering, Faculty, University of Debrecen, 4028 Debrecen, Ótemető St.-2.-4., hancz.g@gmail.com

${ }^{2}$ Hortobágy National Park, 4024, Debrecen, Sumen u. 2., vagy 4002 Pf. 216 (52) 529-920 ;

aradicsaba@freemail.hu

Abstract: The current usual practice of disposing used thermal bathing waters in Hungary is to release them directly or indirectly - through the public sewer system or a conditioning pond - to the relevant drainage canal or other surface water body. In the region of the Great Hungarian Plain (GHP) solely there are eighty operating thermal baths using the surface waters as recipients. Conditioning ponds serve as reservoirs of used thermal waters of high salt content for the irrigation period. According to the recommended alternative solution used thermal waters would be released onto already saline - mostly landscape-conservation - areas which are spread all over the region of the GHP and they suffer from lack of water because of decreased water table level. Beside the introduction of the potential advantages of the conception the hydrological balance of the region of the examined GHP is developed in order to ensure that the quality of ground waters are not endangered and to estimate the potential

Keywords: preservation of drying wetlands, active management of resilience, water balance, sustainable thermal water use, drought, semi aridity

\section{Materials and methods}

1. Water scarcity in the Hungarian Lowland (figure 1):

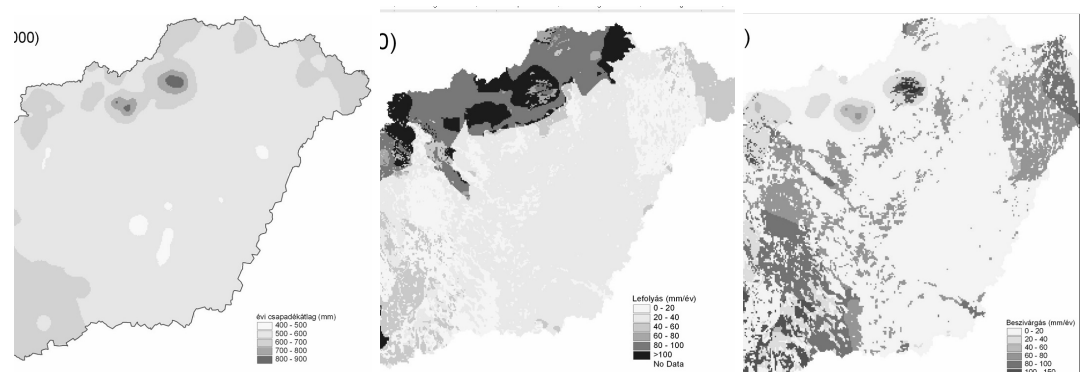

Figure 1. Annual mean precipitation, runoff nad infiltration in the GHP between 1991.-2000.

http://www.epito.bme.hu/vcst/oktatas/feltoltesek/BMEEOVK-SQ4/vizmerleg_uj2.ppt\#412,11,11. dia Seasonal differences make summer water shortages more severe compared to annual deficits. Water table fluctuations due to the river regulations resulted in the development of 750000 ha-s of secondary salinated area in addition to the already existing 400000 ha-s of genetic saline areas. The chronic water scarcity along with the given extreme continental - semi arid - climate of the GHP changes the landscape to a still more extreme direction (Horváth, 2003). Water scarcity within the GHP is the most severe in the middle part of the Danube-Tisza Interfluve, the „Hátság”. Ground waters percolate towards the valleys so it would not compensate lack of precipitation and surface runoff. The longest dry period of twelve years came about between 1983-1994 (Figure2). Anthropogenic effects is assumed to put out about 25\% (Pálfai, 2005) 


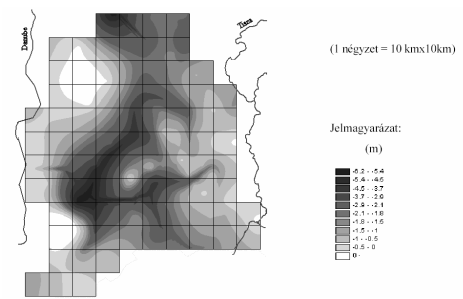

Figure2. Deviation from the average water table of years 1990-1974 in March,1995 Rakonczai, Kovács, 2008

A few weeks or months without rain in the vegetation period results in biomass reduction. Longer period without rain results in the deviant variation of the water table along with the changing of the natural flora. Longer - decadal scale - drought makes the soil transform along with the most apparent ecological and landscape alterations (Rakonczai, 2004). In semiarid regions like the GHP shallow groundwater is sensible to a long spell of dry weather. Sustained periods of drought result in increased water demand and decreased water resources (Istvánovics, Hahn, Somlyódy, 2000). Climate change is expected to cause a net increase in semi-arid lands (Yeo, 1998).

2. Adverse effects of current disposal practices (Hancz, 2004.) are different. They change significantly the natural regional water circle and pollute surface waters with salt generating secondary salinity of irrigated soils. The soil on one third of the GHP is saline, partly alkaline. Another one third is potentially saline, mainly due to irrigation. Only one third is not affected by salinization processes (Tóth et al, 2001).

3. Irrigation water demand in the GHP is not expected to lessen (Somlyódy, 2000), because irrigation is essential to mitigate drought in the agricultural areas.

Ecological water demand of wetlands is also a challenge. Prior to river regulations the floods had left behind stagnant water on areas without runoff. This is the origin of saline lakes and wetlands in the region. In summertime evaporation exceeds precipitation so these saline lakes are characteristically temporal, drying waters. Decline of wetland surfaces is demonstrable by remote sensing methods. The adverse process seems to be irreversible on $1500 \mathrm{~km}^{2}$ s. (Kovács-Rakonczai, 2008). The level along with the surface of the saline lakes has decreased significantly and saline grasslands are drying. The resilience of the wetlands have been reduced by human activities through altering disturbance regimes, like water table fluctuations (Gunderson, 2000).

4. EC (Electrical Conductivity) which is used to characterize the halobity (Felföldy, 2000) of waters and express salt concentration was measured on the watershed of river Kösely on the GHP (Figure 5). This river is loaded with used thermal bathing water all year long. According to measured EC data and requirements and ordinances regarding salt content, we can assess that the investigated water bodies do not meet the requirements for irrigation waters (Várallyay-Fejér, 1936), and according to the Hungarian Standard waters are mostly "tolerable", rarely "good" or "polluted" (Figure 4). 


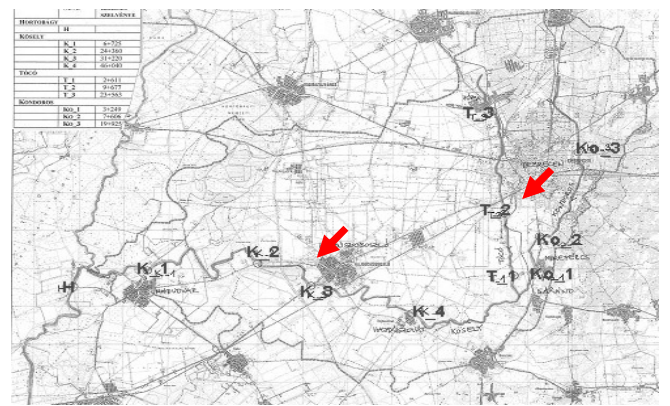

Figure 3. Investigated watershed of river Kösely in the Hungarian Lowland, within the Tisza River basin,own figure

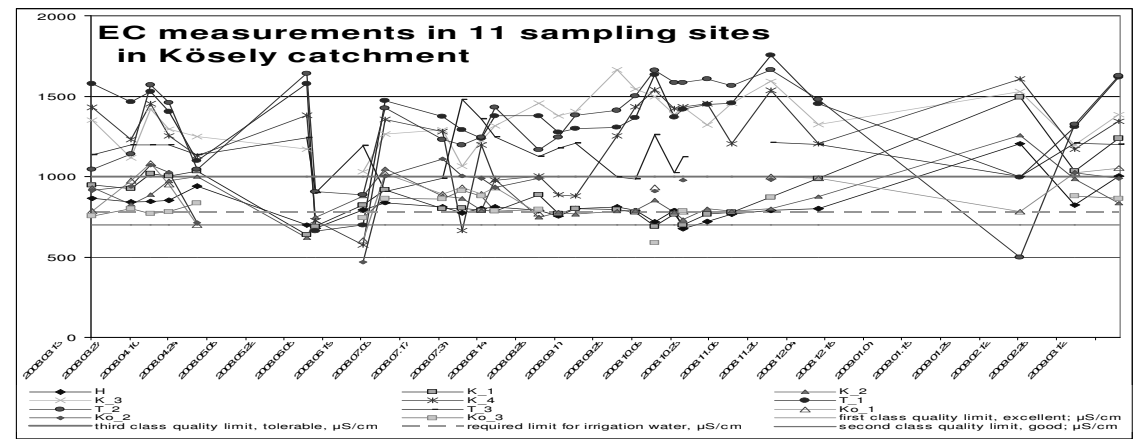

Figure 4. One year-long EC measurements on river Kösely and tributaries and water quality requirements, own figure

\section{Results and discussion}
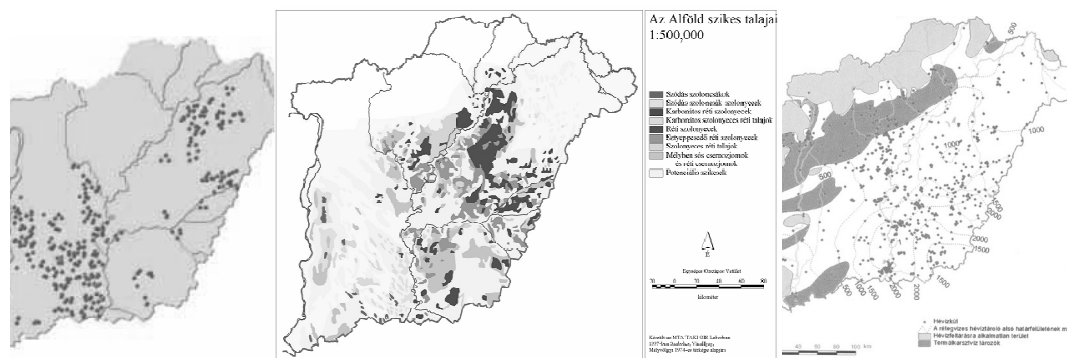

Figure 5. Point-map of saline lakes; map of saline soils and Geothermal wells in the GHP KöM TVH, Szikes tavak, Nemzeti Ökológiai Hálózat

KvvM, Thermal water resources in Hungary, their utilisation and protection

Saline wetlands need to be preserved and water quality protection and reuse is needed because degree of salinity is growing and water resources are reducing. We propose to release used thermal bathing waters onto saline lands or into temporal or permanent 
saline lakes in the surroundings. The feasibility is confirmed by the maps (figures 5 . ) of thermal baths and saline areas in the GHP and by the fact that saline areas are not suitable for agricultural utilisation but are long-term salt deposits.

Measurements should take place prior to discharge to prevent pollution of ground waters. In case of great sensitivity we may establish "evaporating pans" for continuous discharge of a shallow water layer excluding leaching. In case of non-sensible areas we may establish ponds serving for groundwater recharge and evaporation as well. Advantages of the proposed solution are as follows: active support of wetlands to regain or preserve their resilience; reverse the trend of loosing wetlands along with their environmental services; decrease the fragmentation of wetland habitats; help local governments to meet water quality requirements; improve surface water quality; and increase availability for irrigation water

\section{References}

Felföldy L.: 1981. A vizek környezettana: Általános hidrobiológia. - Mezőgazdasági Kiadó, Budapest

Gunderson H.L.: 2000. Ecological resilience - in theory and application Annual Review of Ecology and Systematics, 31. doi: 10.1146/annurev.ecolsys.31.1.425

Hancz, G..: 2009. A Kösely vízfolyás és mellékágainak sóterheléssel összefüggő minősége http://store1.digitalcity.eu.com/store/clients/release/musz_fuz_05.pdf

Hancz, G.: 2004. Adverse environmental impacts of thermal water utilization; Debreceni Müszaki Közlemények, III.évf.2. szám

Horváth, B..: 2003. A Tisza ökológiai szerepe; 6th Hungarian Kongress of Ecologists; Gödöllő

Istvánovics V. - Hahn I. - Somlyódy L.: 2000. A jövő vízgazdálkodása: kihívás a mérnök és az ökológua számára. Magyar Tudomány 45. 10. 1202-1200.

Kovács F. - Rakonczai J.: 2008. A szárazodás és környezeti hatásai az alföldön Szegedi Tudományegyetem Természeti Földrajzi és Geoinformatikai Tanszék; Acta Botanica Hungarica 50(1-2), 19-60. www.geo.uszeged.hu/publi/pdf/rj/b4_3.pdf

Pálfai I.: 2005. Vízháztartási változások és vízgazdálkodási feladatok a Duna - Tisza közén; Hidrológiai Tájékoztató, Magyar Hidrológiai Társaság

Rakonczai J.: 2004. A környezeti változások hatása az alföldi táj átalakulására II. Magyar Földrajzi Konferencia Szeged, 2004. szeptember 2-4 geography.hu/mfk2004/mfk2004

Somlyódy L. /Ed/ : 2000. A hazai vízgazdálkodás stratégiai kérdései. Magyar Tudományos Akadémia, Budapest.

Szikes tavak; Nemzeti Ökológiai Hálózat 4: 2002. www.kvvm.hu/cimg/documents/1231_szikestavakmagyar_2_3.pdf

Tóth T. - Kuti L. - Kabos S. - Pásztor L.: 2001. Az alföldi szikes talajok elterjedését meghatározó agrogeológiai tényezők térinformatikai elemzése 1:500 000 méretarányban. http://geography.hu /mfk2001/cikkek/TothKutiKabosPasztor.pdf

Várallyay G. - Fejér D.: 1936. Adatok az öntözővizek minőségi megítéléséhez. Kisérl. Közl., 39: 1-3..

Yeo, A.: 1998. Predicting the interaction between the effects of salinity and climate change on crop plants ; Plant Stress Unit, School of Biological Sciences, The University of Sussex Brighton, BN1 9QG UK 


\title{
THE CREATION OF PHYSIOLOGICAL STRESS OF PLANTS IN THE METEOROLOGICAL CONDITIONS OF SOIL DROUGHT
}

\section{Branislav KANDRA}

Institute of Hydrology, Slovak Acagemy of Sciences SAV, 07101 Michalovce, Hollého 42, kandra@uh.savba.sk

\begin{abstract}
Physiological stress of plant cover is, in term of water, balance defined as a threshold point. This point means the potential on the retention curve with $\mathrm{pF}$ value of 3,3 . At the moisture relevant to this potential a crop is getting into the stress and its hydrological processes are restricted for survival. Meteorological drought is most frequently defined as a negative deviation of precipitation from a normal period during a specific temporal one. In general meteorological drought leads to the deficiency of soil water that is available for the plant cover.

Non precipitation periods that led to the soil drought formation were separated from the time series of the vegetal periods during the years 1970-2008. Critical water regime elements were quantified in the process of physiological stress formation of the field crops. Furthermore the influence of initial soil water storage on its future development and availability for crop cover during non precipitation period were quantified as well.
\end{abstract}

Keywords: physiological stress, meteorological drought, soil drought, water storage

\section{Introduction}

From the stand of plant water availability we can say about optimal soil water state, that it does not have any negative influence on the physiological stress of plants, that could lead to worse economical profit. In case, when this optimal moisture limit is exceeded the plants have worse living and physiological stress is coming up. Physiological stress badge is a signifying start of soil drought (Gomboš, 2008; Gomboš and Pavelková, 2009, Šoltész and Baroková, 2003-2004). In term of soil moisture, the negative badge of soil profile drying starts in the threshold point (TP), that means the potential on the retention curve with $\mathrm{pF}$ value of 3,3 (Tall, 2007; Nagy at al., 2007). Soil water deficit is closely associated with badge of meteorological elements. Creation of soil drought starts with certain retardation as an issue of meteorological drought. Meteorological drought is most often defined as a negative deviation of precipitation from normal period during some time period.

The aim of this article is to analyse the longest rainless periods (RP) during investigated line of growing seasons of years 1970-2008. Critical elements of water regime were quantified in the process of physiological stress creation of field plants during separated rainless periods, that led to soil drought creation. Next, the influence of initial soil water storage on its consecutive development and availability for plant cover during rainless periods were analyzed.

\section{Materials and methods}

The rainless periods were chosen from the data obtained from the climatic station Milhostov situated in the central part of Eastern Slovakian lowland (ESL). Statistically relevant rainless periods with a total daily precipitation of $\mathrm{f}(0)=0,00 \mathrm{~mm}$ were separated in this locality from the investigated 38 years period (1970-2008) of vegetation seasons. Longest rainless periods, that started during vegetation season (April-September) were 
chosen for a detailed analysis. In the chosen case the days started in march and ran over the vegetation season. 5 longest rainless periods were finally ranged to the valuation. During this time of meteorological drought some water regime elements in the soil profile of Milhostov were analyzed. Quantification of these elements was realized numerically by the mathematical model GLOBAL with one day periodicity. Development of potential and actual evapotranspiration, water storage in $1 \mathrm{~m}$ of soil depth and ground water level were evaluated. Next step presented comparison between two parallel water storage curves during rainless period of vegetation season 1974. First soil content state reflected real conditions and second one was affected by simulated change of initial water storage on the level near full water capacity (FWC). In the above case, other soil water storage development with regard to expected betterment of water availability for the plant was pursued.

\section{Results and discussion}

Five rainless periods with its characteristics and excedance probability are selected in the tab. 1. These time periods present the time of meteorological drought when the soil water storage was going down. Dynamics of soil moisture changes with its intensity are defined by relative index $\mathrm{i}_{\mathrm{zz}}=\Delta \mathrm{WS} / \mathrm{d}\left[\mathrm{mm}\right.$.deñ $\left.{ }^{-1}\right]$. The soil water storage (WS) changes and its intensity $i_{z z}$ during rainless periods depends on the soil moisture at the beginning of meteorological drought, evapotranspiration and GWL position.

Table 1. Fundamental characteristics of examined rainless periods in term of water regime and exceeded probability ("d" - days count in period, "P" - values of theoretical exceeded curve of furthermost rainless periods during examined years 1970-2008 at Milhostov station," pr" - periodicity of furthermost rainless periods, "WS" - water storage in $1 \mathrm{~m}$ soil depth, "TP" - threshold point $(38,8 \mathrm{~mm})$, "ED" - evapotranspiration deficit $\left(\mathrm{ET}_{0}-\mathrm{ET}_{\mathrm{a}}\right)$, " $\Delta$ " - (start time-end time), " GWL" - ground water level)

\begin{tabular}{|c|c|c|c|c|c|c|c|c|c|}
\hline \multicolumn{10}{|c|}{ for daily precipitation amount $\mathrm{f}(0)=0,00 \mathrm{~mm}$} \\
\hline \multicolumn{2}{|c|}{ rainless periods $(\mathrm{RP})$} & $\mathrm{d}$ & $\mathrm{P}$ & $\mathrm{pr}$ & WS & WS & WS/TP & WS/TP & ED \\
\hline \multirow{2}{*}{$\begin{array}{l}\text { start } \\
\text { time }\end{array}$} & \multirow{2}{*}{$\begin{array}{l}\text { end } \\
\text { time }\end{array}$} & $\begin{array}{l}\text { days } \\
\text { count }\end{array}$ & $\begin{array}{l}\text { prob- } \\
\text { ability }\end{array}$ & $\begin{array}{l}\text { perio- } \\
\text { dicity }\end{array}$ & $\begin{array}{l}\text { start } \\
\text { time }\end{array}$ & $\begin{array}{l}\text { end } \\
\text { time }\end{array}$ & $\begin{array}{l}\text { start } \\
\text { time }\end{array}$ & $\begin{array}{l}\text { end } \\
\text { time }\end{array}$ & $\begin{array}{l}\text { start } \\
\text { time }\end{array}$ \\
\hline & & [days] & {$[\%]$} & years & {$[\mathrm{mm}]$} & {$[\mathrm{mm}]$} & {$[-]$} & {$[-]$} & {$[\mathrm{mm}]$} \\
\hline 18.3 .1974 & 14.4.1974 & 28 & 5,6 & 18,0 & 379,01 & 269,10 & 1,15 & 0,82 & 0,00 \\
\hline 5.8 .1976 & 31.8 .1976 & 27 & 6,8 & 14,6 & 171,88 & 126,72 & 0,52 & 0,39 & 0,37 \\
\hline 14.3 .1995 & 9.4 .1995 & 27 & 6,8 & 14,6 & 400,76 & 295,31 & 1,22 & 0,90 & 0,00 \\
\hline 24.3 .1999 & 12.4 .1999 & 20 & 23,8 & 4,2 & 512,83 & 482,34 & 1,56 & 1,47 & 0,00 \\
\hline 23.3 .2002 & 11.4 .2002 & 20 & 23,8 & 4,2 & 408,42 & 249,68 & 1,24 & 0,76 & 0,00 \\
\hline \multicolumn{2}{|c|}{ rainless periods $(\mathrm{RP})$} & ED & ED & $\sum E D$ & $\Delta \mathrm{WS} / \mathrm{d}$ & GWL & GWL & $\Delta \mathrm{GWL}$ & $\Delta \mathrm{GWL} / \mathrm{d}$ \\
\hline \multirow{2}{*}{$\begin{array}{l}\text { start } \\
\text { time }\end{array}$} & \multirow{2}{*}{$\begin{array}{l}\text { end } \\
\text { time }\end{array}$} & $\max$ & $\begin{array}{l}\text { end } \\
\text { time }\end{array}$ & - & - & $\begin{array}{l}\text { start } \\
\text { time }\end{array}$ & $\begin{array}{l}\text { end } \\
\text { time }\end{array}$ & - & - \\
\hline & & {$[\mathrm{mm}]$} & {$[\mathrm{mm}]$} & {$[\mathrm{mm}]$} & {$[\mathrm{mm} / \mathrm{d}]$} & {$[\mathrm{cm}]$} & {$[\mathrm{cm}]$} & {$[\mathrm{cm}]$} & {$[\mathrm{cm} / \mathrm{d}]$} \\
\hline 18.3 .1974 & 14.4 .1974 & 3,07 & 3,07 & 31,35 & 3,9 & $-152,81$ & $-166,48$ & $-13,67$ & $-0,1$ \\
\hline 5.8 .1976 & 31.8 .1976 & 3,70 & 2,31 & 57,11 & 1,7 & $-152,28$ & $-166,96$ & $-14,68$ & $-0,5$ \\
\hline 14.3 .1995 & 9.4 .1995 & 0,79 & 0,51 & 2,13 & 3,9 & $-153,10$ & $-149,83$ & 3,26 & 0,1 \\
\hline 24.3 .1999 & 12.4 .1999 & 0,00 & 0,00 & 0,00 & 1,5 & $-55,24$ & $-71,21$ & $-15,97$ & $-0,8$ \\
\hline 23.3 .2002 & 11.4 .2002 & 1,84 & 1,12 & 10,65 & 7,9 & $-108,40$ & $-117,93$ & $-9,53$ & $-0,5$ \\
\hline
\end{tabular}

Figure 1 shows a retardation of soil drought starting affected by the initial soil water storage $\left(\mathrm{WS}_{\mathrm{i}}\right)$ enhancement at the beginning of rainless period. Optimal soil moisture 
extends from 7 to 10 days. From the figure follows that if a soil profile is not under influence of GWL, the soil profile conversion to the soil drought state is connected with creation of evapotranspiration deficit $\sum E D$. There are also illustrated daily values of potential $\left(\mathrm{ET}_{0}\right)$ and actual $\left(\mathrm{ET}_{\mathrm{a}}\right)$ evapotranspiration, WS, GWL and TP during RP of vegetation season in 1974. Soil drought index $\mathrm{I}_{\mathrm{SD}}=\mathrm{WS} / \mathrm{TP}$ provides an identification of soil drought start. If the value is $\mathrm{I}_{\mathrm{SD}}=1$, the soil drought begins and plants are going to the physiological stress in consequence of water deficit. This state continues till $\mathrm{I}_{\mathrm{SD}}>1$.
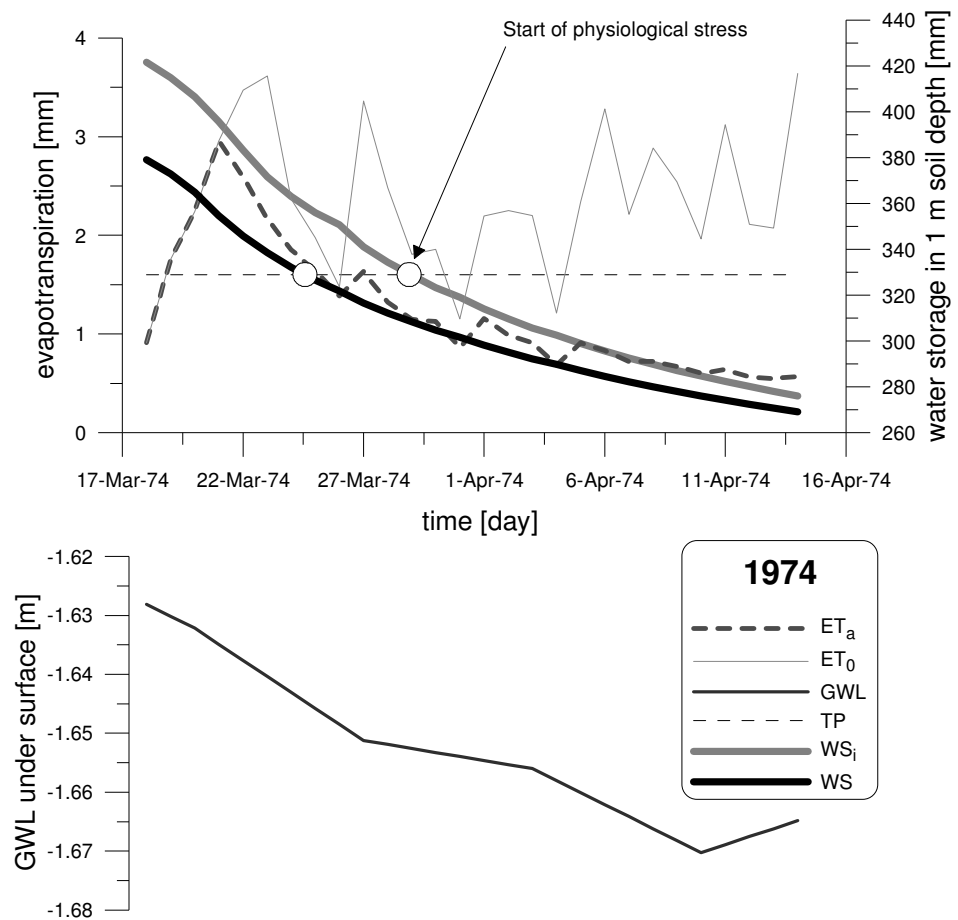

Figure1. Influence of initial water storage on the water availability for the plant cover $\left(\mathrm{WS}_{\mathrm{i}}, \mathrm{i}-\right.$ mounted initial water storage) and daily values of potential and actual evapotranspiration with relation to soil water storage and ground water level during the chosen rainless period with criterion of daily precipitation sum $(\mathrm{f}(0)=0,00 \mathrm{~mm})$

The soil moisture decreasing has two phases. During first phase the soil moisture is going down from FWC to TP. The second phase starts with moisture decreasing under TP. The soil profile is practically drying and the physiological stress of plants starts because there is worse water availability. The drying process begins at the value of ED $>0$, that means $\mathrm{ET}_{\mathrm{a}}<\mathrm{ET}_{0}$. The $\mathrm{ED}$ value increase is signifying the soil drought start and it meets TP. Soil drought identification by ED is more precise than by TP, but more difficult in regard of calculation and input database. 


\section{Conclusions}

The rainless periods in this article were analyzed during the separated vegetation periods of investigated range 1970-2008. The selected water regime elements and water storage in $1 \mathrm{~m}$ of soil depth under influence of GWL and initial soil moisture were quantified by numerical simulation during the longest rainless periods as lines of meteorological drought in the locality of Milhostov (Table 1). The main aim was an evaluation of rainless periods influence on the start and development of soil drought as reason of plant physiological stress creation. Soil water storage changes and its intensity during meteorological drought is minor, especially when GWL extends to the balanced soil layer and endows it by water. The soil moisture decreasing has two phases. During the first phase the soil moisture is going down from FWC to TP and $\mathrm{ED}=0\left(\mathrm{ET}_{\mathrm{a}}=\mathrm{ET}_{0}\right)$. The second phase starts with moisture decreasing under TP, when ED $>0\left(\mathrm{ET}_{\mathrm{a}}<\mathrm{ET}_{0}\right)$. The second phase leads to soil drought start and causes physiological stress of crop. Influence of initial soil water storage on the next advancement during RP illustrates WS in the year 1974 obr. 1 . Initial soil water storage near saturate state $(421,54 \mathrm{~mm})$ extends optimal soil moisture from 7 to 10 days.

\section{Acknowledgements}

The authors would like to thank for the kind support of the project VEGA 2/0130/09.

\section{References}

Gomboš, M. - Pavelková, D.: 2009. Analýza meteorologického sucha v centrálnej časti Východoslovenskej nížiny. In Acta Hydrologica Slovaca. ISSN 1335-6291, 2009, roč. 10, č. 1 69-74.

Gomboš, M.: 2008. Water storage dependability in root zone of soil. Cereal Research Communications 36 1191-1194.

Nagy V. - Sterauerova V. - Neményi M. - Milics G. - Koltai G: 2007. The role of soil moisture regime in sustainable agriculture in both side of river Danube in 2002 and 2003. Cereal Research Communications, 35. 2. 821-824.

Šoltész, A. - Baroková,D.: 2003-2004. Analysis, prognosis and control of groundwater level regime based on means of numerical modeling. George Halasi-Kun, editor: Pollution and Water Resources. Columbia Univ. Seminar Proc., Vol. XXXV, 334-347.

Tall, A.: 2007. Impact of canopy on the water storage dynamics in soil. Cereal Research Communications, $\mathbf{3 5}$ : 2. $1185-1188$. 


\title{
THE EFFECT OF GROUNDWATER LEVEL SINKAGE TO GW RELATED ECOSYSTEMS IN SOUTH DANUBE-TISZA INTERFLUVE, HUNGARY
}

\author{
Balázs KOVÁCS ${ }^{1}$ - János SZANYI ${ }^{2}$ - Katalin MARGÓCZI ${ }^{3}$ \\ ${ }^{1}$ Institute of Environmental Management, University of Miskolc, 3515 Miskolc-Egyetemvaros, \\ kovacs.balazs@gama-geo.hu \\ ${ }^{2}$ Dept. of Mineralogy, Geochemistry and Petrography, University of Szeged, 6722 Szeged, Egyetem u. 2-6. \\ szanyi@iif.u-szeged.hu \\ ${ }^{3}$ Department of Ecology, University of Szeged, 6726 Szeged, Közép fasor 52. margoczi@ bio.u-szeged.hu
}

\begin{abstract}
Vegetation is very sensitive to the depth of groundwater. Unfortunately the groundwater level fluctuates not only periodically but also there are trends showing regional decrease of the groundwater levels. One of the most vulnerable regions to groundwater sinkage in Hungary lies in South Danube-Tisza Interfluve. Our study aims to predict the shallow groundwater level changes due to decrease of precipitation and natural recharge caused by the climate change at different groundwater production scenarios on the study area. The groundwater regime was investigated using a regional numerical GW flow model based on a conceptual hydrogeologic model. Based on the model two sites of interest were chosen to investigate the changes of vegetation pattern, where significant drop of water levels may to happen. The botanical survey showed relevant changes of vegetation pattern after a few years of investigation. The main result of this study is to reveal the connection of hydrological processes and vegetation pattern.
\end{abstract}

Keywords: global climate change, groundwater modelling, vegetation pattern change

\section{Introduction}

In frame of the successfully completed "Sustainable development of Hungarian Serbian transboundary aquifer (SUDEHSTRA)" project a large scale regional groundwater flow model (Stevanovic et al., 2008) was developed which was expanded with a long-term botanic survey. Since groundwater resources within thick Tertiary aquifer layers deposited between the Danube and Tisa Rivers are vital for the economy and the society of the two countries, and almost one million of inhabitants along the border use them for drinking. The huge potable and industrial water needs, the decrease of natural recharge and the possible effects of climate changes lead to significant decrease of GW levels. The flow potential decrease at the highest points reached approx $10 \mathrm{~m}$, but at large regions it is over $1 \mathrm{~m}$ (Tóth - Almási, 2001). Large number of authors dealing with different effects of water related stresses on the flora (Morschhauser Milics, 2009; Başer et al., 2005, Nagy et al., 2007) but also on the potential effects of global climate change or weather related stresses in general (Földesi et al., 2005), but there are only a few where a direct investigation of interference of hydrogeological and botanical conditions was performed.

\section{Materials and methods}

The studied aquifer system is located between the Danube and Tisa (Tisza) Rivers and extends to the vicinity of Kiskunfelegyhaza on the Hungarian side (North) and to Vrbas in Serbia (South) (Figure 1.). The hydrodynamic model was built in Processing MODFLOW (Chiang - Kinzelbach, 2001) environment as a multi-layer model with ten layers (five aquifers and five semi permeable layers between them). Hydraulic parameters are approximated on the basis of provided documentation (Szücs et al., 
2006) as representative values for the whole layer. Due the quantity and quality of the available data the prognosis based only steady state flow conditions, thus, the prediction and forecasting done under this model can only be roughly approximated for some period covering next 15-20 years.

The numerical predictive computations involved two major scenarios: Climate changes which were attempted in the decrease of the recharge $(-10 \%$ or $-20 \%)$, and increase or decrease of groundwater production. Since the large GW exploitation in Serbia is due to low water price, the production's decrease is forecasted for the future. In Hungary it is also possible that the yield of wells is increasing in the future with up to $10 \%$, but it is also very possible that the efforts to make artificial recharge and to reduce surface runoff will happen. Using the model the most vulnerable areas were delineated and used for botanical investigation.

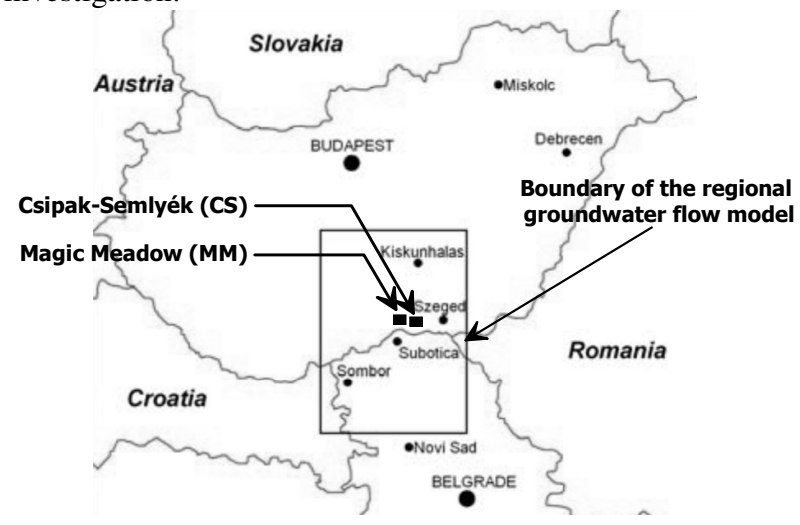

Figure 1. Overview of the investigated area

Two pieces of about 100-100 ha large dune slack meadows were chosen for detailed botanical and hydrogeological investigation: the Csipak-semlyék (CS), and the s.c. „Magic" Meadow (MM) (this nickname were given by botanists, because of its unusual richness in protected plants). Permanent transects were established in 2005, which crossed the stands of different vegetation zones in different elevation level, as marsh zone, transitional zone and dry steppe zone (Figure 2.) Cenological relevés were made along the transects, in $5 \times 5 \mathrm{~m}$ plots ( 42 plots in CS site, and 27 plots in the MM) by estimating the percent cover rate of plant species.
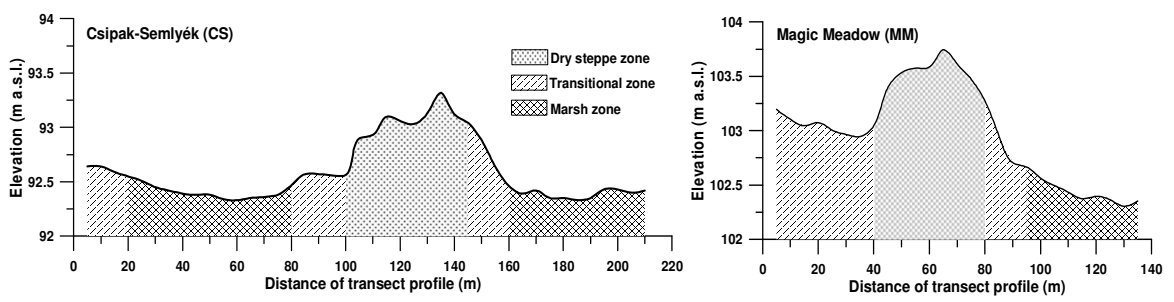

Figure 2. Profile of the transects in CS and MM sites, and the position of vegetation zones 
The survey was repeated in 2008 and 2009 in the same study plots. The occurring plant species were categorized by their relative ecological indicator values according to Borhidi (1993). The used soil moisture or water table indicator categories were: WB 810 Plants of wet, occasionally flooded soils; WB 5-7 Plants of fresh and moist soils; WB 2-4Xero-tolerant plants.

\section{Results and discussion}

The results of the prognosis were shown as hydraulic heads in all aquifer layers and as drawdown maps of the different water-bearing layers. Calculations showed that there are sites where in case of almost all scenarios the sinkage of GW level is above $1.5 \mathrm{~m}$ in the next 20 years (Figure 3). The botanical studies were performed in 2005, 2008 and 2009, parallel to this meteorological and hydrogeological data were also collected. The characteristics of precipitation and of duration curves of GW levels below ground surface are shown on Figure 4.) Independently from it causes the last 5 years showed a continuous sinkage of GW levels which was also detected in the change of vegetation pattern.

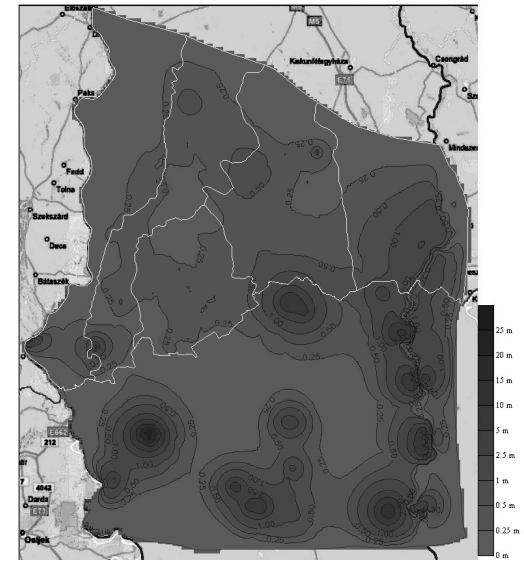

Figure 3. GW level decrease due to GW production and decrease of recharge

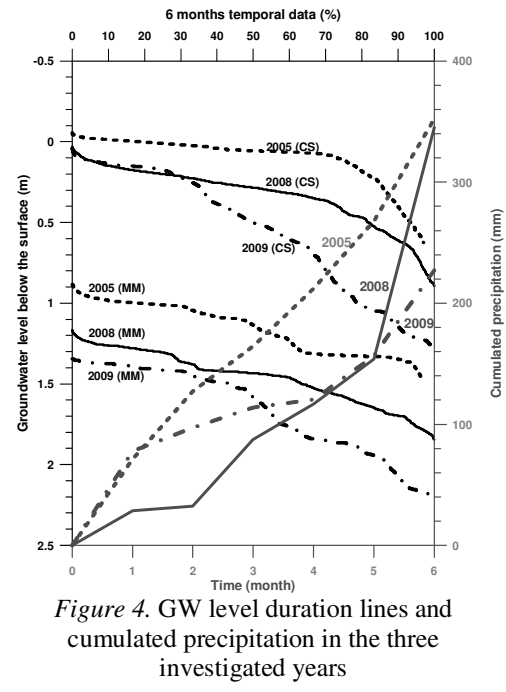

The plants of fresh and moist soils (WB 5-7) occupied the place of the plants of wet-, occasionally flooded soils (WB 8-10) in the relatively dry 2008 year, and further in the very dry 2009 year, especially in the transitional zone. In the MM site the vegetation of marsh zone was quite stable. In the steppe zone the cover of plants of fresh and moist soils (WB 5-7) slightly increased in the dry year. In the CS site the cover of vegetation of steppe zone is lower in the dry year. The vegetation change indicates the decrease of groundwater level even in the year, with higher precipitation just before vegetation survey (2008). The location of MM site is near to the top of the large sand tableland between 102 and 104 m elevation above Baltic Sea level, rather on a ,terrace” than in a 
depression. The CS site is on lower level, toward to the feet of the tableland between 91.5 and $93.5 \mathrm{~m}$, and really in a depression. The vegetation has been adapted to the formerly decreased groundwater level in MM site, but the vegetation change is continuous in the CS site (Figure 5.).

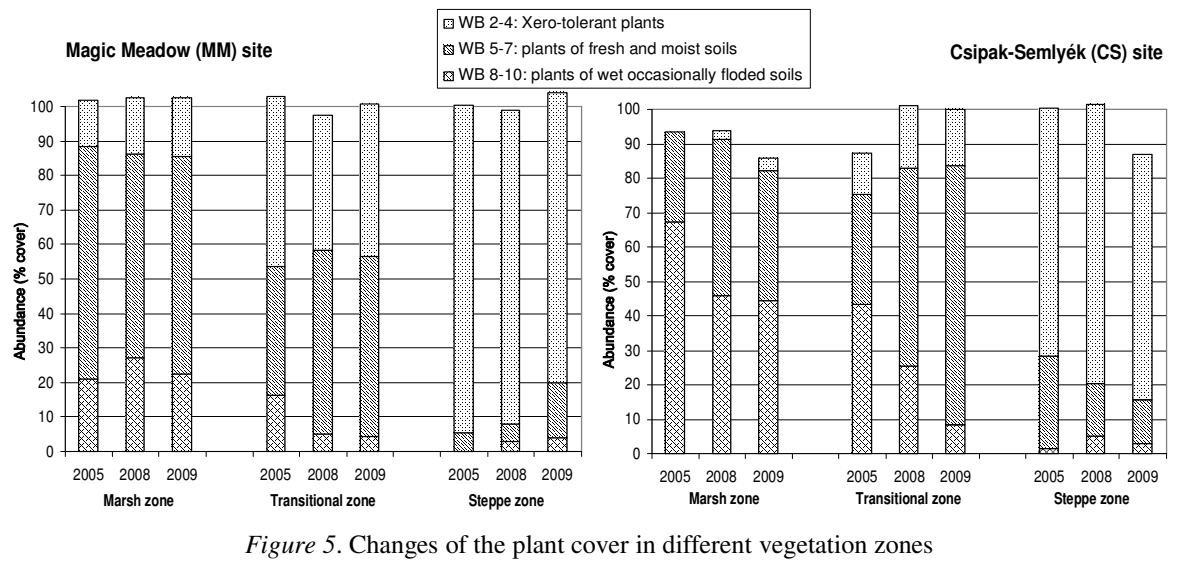

\section{Conclusions}

GW flow modelling show large regions in the Hungarian Plain, where decrease of GW levels - and as our vegetation pattern analysis proved - also alteration of vegetation is foreseen in the near future. Since wetlands are very sensitive to water related stresses, relevant reversible and also potentially irreversible changes of vegetation are predicted. Since the trend of GW level sinking seems to be monotonous we will have to adjust our agricultural and nature protective activities to the new conditions.

\section{References}

Başer, I. - Şehirali, S. - Orta, H. - Erdem, T. - Erdem, Y.: 2004. Effect of different water stresses on the yield and yield components of winter wheat, Cereal Research Comm. 32.: 2. 217-223.

Borhidi A.: 1993. Social behaviour types of the Hungarian flora, its naturalness and relative ecological indicator values. (in Hungarian), Pécs.

Chiang, W-Hs. - Kinzelbach, W.: 2001. 3D-Groundwater Modelling with PMWIN, A Simulation System for Modeling Groundwater Flow and Pollution, Springer-Verlag Berlin, Heidelberg, ISBN 3-540-67744-5

Földesi P. - Singh, Mahesh Kumar - Skov, F. - Jolánkai M. - Gyuricza Cs.: 2005. Changing climate struck biodiversity in Asia and the Pacific: an overview, Cereal Research Comm. 33: 1. 201-203.

Morschhauser T. - Milics G.: 2009. Mapping stress in natural and artificial ecosystems. Cereal Research Communications 37. 577-580.

Nagy V. - Stekauerova V. - Neményi M. - Milics G. - Koltai G.: 2007. The role of soil moisture regime in sustainable agriculture in both side of river Danube in 2002 and 2003. Cereal Research Communications, 35. 2. 821-824.

Stevanovic - Kozák - Lazic - Szanyi - Polomcic - Kovács - Török - Milanovic - Hajdin - I. Vass: 2008. Towards sustainable management of transboundary Hungarian-Serbian Aquifer, Proc. IV. Int. Symp. on Transboundary Waters Management, Thessaloniki, Greece

Szucs P. - Civan F. - Virag M: 2006. Applicability of the most frequent value method in groundwater modeling, Hydrogeology Journal 14: 31-43. Springer-Verlag

Tóth J. - Almási I.: 2001. Interpretation of absorbed fluid potential patterns in a deep sedimentary basin under tectonic compression: Hungarian Great Plain, Pannonian Basin. Geofluids 1. 11-36. 


\title{
WATER MANAGEMENT IN ARID AREAS
}

\author{
Ivett SZÉLES ${ }^{l}$ - Sándor J. ZSARNÓCZAI ${ }^{2}$ - Lajos SZABÓ ${ }^{3}$ \\ ${ }^{1}$ e-mail: szeles.ivett@gtk.szie.hu, PhD Student \\ 2 e-mail: zsarnoczai.sandor@gtk.szie.hu, Assoc. Prof, Dr. (CSc) \\ 3 e-mail: szabo.lajos@gtk.szie.hu, Professor, DR (DSc) \\ Institute of Regional Economics and Rural Development, Faculty of Economic and Social Sciences, Szent \\ István University, 2103 Gödöllő, Páter Károly u. 1. HUNGARY,
}

Abstract: In an arid region groundwater is a very special element in the water resources of communities and political economies. Both surface waters and soil water are susceptible to natural losses which reduce their availability for human use. Water can be quickly transmitted through alluvial aquifers by-human made pumping equipment. Rock aquifers hold much less water and movement through them is slow, except for the lime stones, which have features resembling underground rivers.

Based on the process of saturated alluvial aquifers this can hold 20 per cent of their volume of water, this means that water can be transmitted quickly. Water content can vary from less than five per cent in parts of the formation to 100 per cent in sub-surface lakes.

Even so, only about $10 \%$ of total supply for the region comes from underground sources. However, the more important point that water availability per capita is decreasing in every country of the MENA region. The hydro-potential of the Nile system is enormous, but the energy demand in the Nile basin countries is still small at present, with the exception of Egypt. Before the implementation of year-to-year storage at the Aswan high dam, the Nile floods brought silt to the fields of Egypt containing potassium and phosphorous and could also leach away accumulated salts.

The fine-grained alluvial soils of the Nile valley do not drain easily and need artificial drainage. Because of the hot-arid climate, irrigation water evaporates quickly, leaving behind salt which causes primary salinization. Apart from desalination or imports, the only ways to improve the situation significantly are to: (1) improve water efficiency in existing uses; and (2) shift water from sectors of low to sectors of high water productivity.

Keywords: arid region, groundwater, heavy metal, alluvial aquifers, alluvial soils

\section{Introduction}

In an arid region groundwater is a very special element in the water resources of communities and political economies. Both surface waters and soil water are susceptible to natural losses which reduce their availability for human use.

The growth of population needs much more food production and in consequence of which, water use within unfavourable dry weather conditions based on the global warming process (Ligetvári et al., 2006).

These formations contain very little water. Saturated alluvial aquifers can hold 20 per cent of their volume as water and water can be transmitted through them quickly. By its nature, however, alluvium tends to be found in flat areas and there are no gradients to induce flow. Water can be quickly transmitted through alluvial aquifers by-pumping. Rock aquifers hold much less water and movement through them is slow, except for the limestone, which have features resembling underground rivers. In limestone the volumes stored vary widely across the aquifer according to the arrangement of the dissolved caves. Water content can vary from less than five per cent in parts of the formation to 100 per cent in sub-surface lakes. 


\section{Materials and methods}

Rivers are the best known sources of water, and those in our region include two of the greatest in the world, the Nile and the Euphrates. As well many short streams or ephemeral valleys (in Arab wadis) occur, typically led by springs in the mountains and spilling into the sea. Aquifers of various types are also common. Some are replenished regularly by rainfall and thus constitute renewable resources; others contain water buried in sediments eons ago and thus constitute non-renewable resources; a few others occur along fracture zones. Over time, as surface sources have become fully committed and as technology has permitted deeper drilling, there has been a shift from surface to underground water. Even so, only about $10 \%$ of total supply for the region comes from underground sources. The share of underground water approaches $100 \%$ in the Arabian Peninsula.

\section{Results and discussion}

The construction of the Aswan high dam has affected the entire economy of Egypt, allowing reliable irrigation throughout the year and satisfying about $40 \%$ or less of the country's energy demands.

Also Egypt's irrigation practices require nearly $55 \times 10^{9} \mathrm{~m}^{3}$ of water from the Nile every year, which is the amount allotted to Egypt by the 1959 Nile Waters Agreement with Sudan. Sudan was allotted $18.5 \times 10^{9} \mathrm{~m}^{3}$ by the same agreement but has been using only $16.5 \times 10^{9} \mathrm{~m}^{3}$ per year in the $1970 \mathrm{~s}$. Monthly flows at various points along the Nile River have been recorded since the late 1800s. From 1871 to 1976 the flow records at Station Aswan were adjusted to account for Sudanese abstractions and evaporation losses. The water stored in the upper rule storage zone is considered to be live storage and can be released to meet irrigation demands or to prevent flooding. Reservoir storage is discredited into 18 states, varying from a maximum of $168.9 \times 10^{9}$ $\mathrm{m}^{3}$ (183-m elevation) to $89.2 \times 10^{9} \mathrm{~m}^{3}$ (168-m elevation).

Even if no more water is devoted to agriculture over the next few years, these countries are in trouble; their water use is unsustainable, which implies that their whole economy is unsustainable. Apart from desalination or imports, the only ways to improve the situation significantly are to: (1) improve water efficiency in existing uses; and (2) shift water from sectors of low to sectors of high water productivity. Before the implementation of year-to-year storage at the Aswan high dam, the Nile floods brought silt to the fields of Egypt containing potassium and phosphorous and could also leach away accumulated salts.

The fine-grained alluvial soils of the Nile valley do not drain easily and need artificial drainage. Because of the hot-arid climate, irrigation water evaporates quickly, leaving behind salt which causes primary salinization. Consequently, farmers had to apply more water to wash the accumulated salts into the ground below the root zone. Deep percolation thus caused a rise in the water table to a few decimetres below the surface level soon after the change to perennial irrigation. The soil then became waterlogged. When the water table is less than two meters deep, capillary forces 
lift it to the surface, where the salts accumulate after evaporation. This is known as secondary salinization. Thus, to avoid primary salinization it is essential to ensure quick infiltration of irrigated water, and to avoid secondary salinization the water table must be kept low.

The availability of water in the region between the Nile and the Euphrates Rivers varies widely in space and in time. Therefore, water management must focus on risk minimization, not maximum utilization. Water stress in the region stems from: (1) excessive demand for fresh water over the renewable supply; (2) pollution from growing volumes of waste; and (3) the natural flow of key water resources across (or under) international borders. The three forces interact, so any resolution must deal with all, together. Such resolution depends upon many changes, including reduction of the use of fresh water for irrigation, higher prices for water, charges for wastewater, greater efforts at water conservation, and institutions to promote joint, management of international water bodies, both surface and underground. Water may be the limiting factor for development throughout this region, but it is far cheaper to share water than to fight over it.

Third, in exactly the same way, we need to compare modern institutions for joint or shared management of trans-boundary water resources with older, but historically effective, institutions for community or common property management of water. In evaluating any of these institutions, as much attention must be paid to water quality as to water quantity; as much to wastewater removal as freshwater supply; and as much to relevance during periods of drought as to years closer to the long-term average.

The combination of such modern market approaches, with their emphasis on efficiency, and traditional institutional approaches, with their emphasis on equity, will prove to be superior in almost every way to any of the various mega projects under consideration to provide major increments of water supply for the region. Nevertheless, it would be useful to make a careful comparison among those mega projects to develop a preferred ranking of them for different nations under various conditions.

In 1982 almost all the irrigated area in Egypt was potentially affected by salt, and at least half of the area $\left(12,000 \mathrm{~km}^{2}\right)$ is already more or less affected. About $400 \mathrm{~km}^{2}$ are provided with drainage systems each year at a cost of US\$200 per hectare. Nevertheless, this is not sufficient to stop salinization. Farmers are unwilling to make this investment, and the government authorities have difficulty in keeping open the drainage channels that are essential for proper functioning of the tile drainage underneath the farmlands. Regulating the flow of the Nile at the Aswan high dam has immensely increased the costs of agriculture for the irrigated lands on the Nile delta by requiring artificial fertilization, drainage systems, and water lifting. On the other hand, some costs have been reduced, such as those for clearing the irrigation channels of silt.

Until high flows on the Blue Nile in 1990 saved the situation, Egypt was facing a national crisis as a result of nine years of falling water levels in the Nile and Lake

317 DOI: $10.1556 /$ Novenyterm.59.2010.Suppl.3 
Nasser. Countermeasures taken to avert the water crisis comprised the following three strategies:

- rationalization-improving irrigation systems to save 86 million $\mathrm{m}^{3}$ of water per year, and recycling agricultural drainage to recover 196 million $\mathrm{m}^{3}$ of water per year;

- river development-building a major new dam on the Nile at Rashid, near Alexandria, to reduce the Nile's flow into the Mediterranean;

- groundwater development - exploiting underground reservoirs to develop nonrenewable groundwater in the deep sandstone aquifers.

\section{Conclusions}

The MENA region is the least well endowed region in the world in terms of soil water. The soil water available each year to MENA farmers is incalculable. In the geographical core of the MENA region the volumes of soil water range from negligible in Egypt and countries of the Arabian Peninsula, to less than 20 per cent of the national water budget in countries like Jordan. In the northern part of the region Turkey, Syria and Iraq enjoy levels of rainfall which provide soil water resources for winter season dry land farming and grazing. This soil water supports significant proportions of the agricultural outputs of the respective economies.

Also for example the soil water can not play significant role of MENA region, it can be important to discover groundwater storage, which can ensure water resource for irrigation. Even this can be very important, when low rainfall can not ensure adequate agricultural yield (see in detailed in Dobó et al., 2006).

Also some experts decided that "Keeping partly the function of food production, agriculture may play a significant role in energy production or industrial raw material production. For this, a good example can be the utilization of biological materials (biomass) for heating. They can also be used for making fuels, as well as vegetable oils can be used in plastic industry, or medicine and different chemicals may also be made from them." (Fogarassy et al., 2007)

\section{References}

Dobó E. - Fekete-Farkas M. - Singh M. K. - Szücs I.: 2006. Ecological-economic analysis of climate change on food system and agricultural vulnerability: a brief overview. Cereal Research Communications. 34: 1. 777-781.

Fogarassy C. - Káposzta J. - Nagy H.: 2007. Externality aggregation of the field of biomass production. Engineering for Rural Development, 6th Scientific Conference, Latvia University of Agriculture - Jelgava 96-101.

Ligetvári F. - Várallyay Gy. - Schweitzer F.: 2006. Sivatagok és az elsivatagosodás nemzetközi éve, UNESCO 2006. Agrokémia és Talajtan, 55. 2. 487-498. 


\title{
WATER PRODUCTIVITY A USEFUL CONCEPT IN RISILIENCE WITHIN AGRO-ECOSYSTEMS
}

\author{
Borivoj PEJIĆ
}

Department of Field and Vegetable Crops, Faculty of Agriculture, University of Novi Sad, Sq. Dositeja Obradovića 8, 21000 Novi Sad, Serbia, e-mail: pejic@polj.uns.ac.rs

\begin{abstract}
The objective of this research was to analyze the productivity of water applied in irrigation and rainfed conditions, and to obtain more information that could improve the production of maize and sugar beet in the Vojvodina Province. The obtained results of irrigation water use efficiency (I/WUE) indicate that the applied irrigation schedule was cost-effective and appropriately designed to satisfy the water requirement of maize and sugar beet plants. The higher productivity of water applied in rainfed conditions (ETa/WUE) in relation to the values established in conditions with irrigation (ETm/WUE) underlined the supplementary character of irrigation in Vojvodina and confirm that only rational irrigation can ensure productive use of applied water without harmful effects and contribute to resilience within agro-ecosystems.
\end{abstract}

Keywords: agro-ecosystem, resilience, water productivity, maize, sugar beet

\section{Introduction}

Any form of agricultural activity disturbs the original equilibrium of the native ecosystem, and soil resilience can be invoked to connote the ability of management to maintain the performance of the soil (Eswaran, 1993; Berzsenyi, 2009). With increasing municipal and industrial demands for water, its allocation for agriculture is decreasing steadily. The major agricultural use of water is for irrigation, which, thus, is affected by decreased supply. Therefore, innovations are needed to increase the efficiency of use of the water that is available. Fundamentally, management practices should ensure that all the water used by evapotranspiration has to be steered towards transpiration as a productive part of water used by plants. Irrigation scheduling is one of the most important tools for developing best management practices for irrigated areas. Improving the precision of irrigation is, therefore, a prerequisite for increasing the efficiency of the water applied to avoid deterioration of crop yields and soil properties in order to reach sustainability and resilience within agro-ecosystems. Taking into consideration that irrigation in Vojvodina has a supplementary character, maize and sugar beet irrigation scheduling gain additional importance. The pre-irrigation soil moisture for those crops is $65-70 \%$ of the field water capacity (FWC), i.e. the irrigation should be applied when about two-thirds of available water in the soil layer to $0.6 \mathrm{~m}$ is spent (Bošnjak, 1982; Dragović, 2000; Mahmoodi et al., 2008). If irrigation schedule is not harmonized with crop requirements and water-physical soil properties, effect of irrigation may be negligible, or missing. Calculation of irrigation water use efficiency (I/WUE) and evapotranspiration water use efficiency coefficients (ETm/WUE and ETa/WUE) may offer a more realistic assessment of the applied irrigation schedules, i.e. the productivity of water in irrigation and rainfed conditions. If calculated values of I/WUE, ETm/WUE and ETa/WUE are below than those previously established for that region, a failure must have occurred in the management practices of crop production, primarily in the application of inadequate irrigation schedule. The objective of this research was to analyze the productivity of water in irrigation and rainfed conditions, in order to maximize the production of maize 
and sugar beet in Vojvodina on one hand, and to reach sustainability and resilience within agro-ecosystems on the other.

\section{Materials and methods}

The experiments were conducted at Rimski Šančevi experiment field of Institute of Field and Vegetable Crops in Novi Sad (N 45 19`, E 19 50`) on the calcareous chernozem soil on the loess terrace, in the period 2004-2006. The experiment was established in a system of random blocks and adapted to technical specifications of the sprinkler irrigation. The experiment included model with irrigation $\left(\mathrm{T}_{\mathrm{I}}-65 \%\right.$ and $70 \%$ of FWC for maize and sugar beet, respectively) and a non-irrigated, control model $\left(\mathrm{T}_{0}\right)$. Irrigation evapotranspiration (ETm) of maize and sugar beet during growing season were calculated using the procedure of water balance, and bioclimatic method using hydrophytothermic indexes. After determining the ETm value, the actual evapotranspiration (ETa) was calculated on the basis of precipitation data and prevegetation soil water reserve. Precipitation $(\mathrm{P})$ and temperature $(\mathrm{T})$ data were obtained from Rimski Šančevi Meteorological Station (Table 1 and 2). The irrigation water use efficiency (I/WUE, $\mathrm{Mg} \mathrm{ha}^{-1} / \mathrm{mm}$ ) coefficient was calculated on the basis of differences in maize and sugar beet yields obtained in models $T_{I}$ and $T_{0}$ in relation to irrigation water applied (I) (Bos, 1985):

$$
\mathrm{I} / \mathrm{WUE}=\mathrm{Y}_{\mathrm{I}}-\mathrm{Ydry}, \mathrm{T}_{0} / \mathrm{I}
$$

Evapotranspiration water use efficiency coefficients (ETm,a/WUE, $\mathrm{Mg} \mathrm{ha}^{-1} / \mathrm{mm}$ ) of maize and sugar beet were calculated on the basis of yields and evapotranspiration rates obtained in $\mathrm{T}_{\mathrm{I}}$ and $\mathrm{T}_{0}$ models (Bos, 1985):

$$
\mathrm{ETm}, \mathrm{a} / \mathrm{WUE}=\mathrm{Y} / \mathrm{ETm}, \mathrm{a}
$$

The experimental maize and sugar beet plots received conventional cultivation practices adjusted to the conditions of irrigation. Maize and sugar beet were harvested at technological maturity and yield was calculated in $\mathrm{Mg} \mathrm{ha}^{-1}$. Statistical processing of data was performed using analysis of variance (ANOVA), and Fisher's LSD test was used for any significant differences at the $\mathrm{P} \leq 0.05$ levels between the mean values.

\section{Results and discussion}

During the study period, on average, there were no statistically significant differences in maize and sugar beet yields between the irrigated and rainfed models. The irrigation increased the yield of maize and sugar beet by $9.9 \%$ or $1.26 \mathrm{Mg} \mathrm{ha}^{-1}$ and $9.6 \%$ or 8.22 $\mathrm{Mg} \mathrm{ha}^{-1}$ respectively (Table 1 and 2).

The value of the I/WUE coefficient of maize for the investigated period was $0.014 \mathrm{Mg} \mathrm{ha}^{-}$ $1 / \mathrm{mm}$, ranging within the interval from $0.010 \mathrm{Mg} \mathrm{ha}^{-1} / \mathrm{mm}$ in years favorable for maize production $(2005,2006)$ to $0.023 \mathrm{Mg} \mathrm{ha}^{-1} / \mathrm{mm}$ in years with scant rainfall (2004) (Table 1). Many authors reported different I/WUE values. Howell et al. (1997) reported that, in Texas, the I/WUE coefficient varied from 0.018 to $0.025 \mathrm{Mg} \mathrm{ha}^{-1} / \mathrm{mm}$, emphasizing that maximum values were obtained when some deficit of readily available soil water occurred during vegetative stage of the growing period of maize. Al-Kaisi and Yin (2003) for north- 
east Kolorado found values of I/WUE in the interval from $0.015-0.027 \mathrm{Mg} \mathrm{ha}^{-1} / \mathrm{mm}$ in conditions with sprinkling irrigation. Takac et al. (2008) obtained the I/WUE values of $0.022 \mathrm{Mg} \mathrm{ha}^{-1} / \mathrm{mm}$ in Slovakia.

The ETm/WUE coefficient value was averagely $0.031 \mathrm{Mg} \mathrm{ha}^{-1} / \mathrm{mm}$, ranging from 0.028 to $0.032 \mathrm{Mg} \mathrm{ha}^{-1} / \mathrm{mm}$, but the average value of ETa/WUE was $0.032 \mathrm{Mg} \mathrm{ha}^{-1} / \mathrm{mm}$, ranging within the interval from 0.030 to $0.035 \mathrm{Mg} \mathrm{ha}^{-1} / \mathrm{mm}$ (Table 1). In Slovakia, Takac et al. (2008) reported the ETm/WUE and ETa/WUE values of $0.018 \mathrm{Mg} \mathrm{ha}^{-1} / \mathrm{mm}$ and $0.021 \mathrm{Mg}$ $\mathrm{ha}^{-1} / \mathrm{mm}$, respectively. In Texas, Howell et al. (1997) found ETm/WUE values 0.020 to $0.030 \mathrm{Mg} \mathrm{ha} / 1 \mathrm{~mm}$ depending on irrigation methods. As a result of low values of ET in humid regions of south-east USA, the ETm/WUE values are very high, reaching $0.030 \mathrm{Mg}$ $\mathrm{ha}^{-1} / \mathrm{mm}$ (Hook, 1985).

Table 1. Corn yield $\left(\mathrm{Mg} \mathrm{ha}^{-1}\right)$ in irrigated $\left(\mathrm{T}_{\mathrm{I}}\right)$ and non-irrigated $\left(\mathrm{T}_{0}\right)$ conditions, precipitation $(\mathrm{P}, \mathrm{mm})$ and mean air temperatures $\left(\mathrm{T}^{0} \mathrm{C}\right)$ in the growing season, irrigation water applied (I mm), ETm $(\mathrm{mm}), \mathrm{ETa}(\mathrm{mm})$, I/WUE (Mg ha $\left.{ }^{-1} / \mathrm{mm}\right)$, ETm,a/WUE $\left(\mathrm{Mg} \mathrm{ha}^{-1} / \mathrm{mm}\right)$

\begin{tabular}{|c|c|c|c|c|c|c|c|c|c|c|}
\hline \multirow{2}{*}{ Year } & \multicolumn{2}{|c|}{ Yield } & \multirow{2}{*}{$\mathrm{P}$} & \multirow{2}{*}{$\mathrm{T}$} & \multirow{2}{*}{ I } & \multirow{2}{*}{ ETm } & \multirow{2}{*}{ ETa } & \multirow{2}{*}{$\begin{array}{c}\text { I } \\
\text { WUE }\end{array}$} & \multirow{2}{*}{$\begin{array}{l}\text { ETm } \\
\text { WUE }\end{array}$} & \multirow{2}{*}{$\begin{array}{c}\text { ETa } \\
\text { WUE }\end{array}$} \\
\hline & $\mathrm{T}_{\mathrm{I}}$ & $\mathrm{T}_{0}$ & & & & & & & & \\
\hline 2004 & 12.96 & 10.50 & 330 & "19.0 & 105 & "458 & 353 & 0.023 & "0.028 & "0.030 \\
\hline 2005 & 14.22 & 13.76 & 496 & 18.6 & 60 & 442 & 442 & 0.010 & 0.032 & 0.031 \\
\hline 2006 & 14.82 & 13.92 & 354 & 19.5 & 180 & 461 & 399 & 0.010 & 0.032 & 0.035 \\
\hline Aver & $13.99 \mathrm{~ns}$ & $12.73 \mathrm{~ns}$ & 393 & 19.0 & 115 & 454 & 398 & 0.014 & 0.031 & 0.032 \\
\hline
\end{tabular}

The I/WUE coefficient value of sugar beet for the investigated period was averagely $0.051 \mathrm{Mg} \mathrm{ha} / 1 \mathrm{~mm}$, ranging from $0.024 \mathrm{Mg} \mathrm{ha}^{-1} / \mathrm{mm}$ in years favorable for sugar beet production $(2005,2006)$ to $0.080 \mathrm{Mg} \mathrm{ha}^{-1} / \mathrm{mm}$ in years with scant rainfall (2004) (Table 2). Draycott (2006) reported the average value of I/WUE for sugar beet of $0.050 \mathrm{Mg} \mathrm{ha}^{-1}$. Kenan and Cafer (2004) reported the value of $0.047 \mathrm{t} \mathrm{ha}^{-1}$ for the conditions of Turkey, Kavazza (1976) the value of $0.055 \mathrm{t} \mathrm{ha}^{-1}$ for the conditions of Italy, Werker and Jaggard (1998) 0.059-0.065 $\mathrm{t} \mathrm{ha}^{-1}$ for England.

The average value of the ETm/WUE coefficient of sugar beet was $0.166 \mathrm{Mg} \mathrm{ha}^{-1} / \mathrm{mm}$, ranging from $0.156 \mathrm{Mg} \mathrm{ha}^{-1} / \mathrm{mm}$ in 2006 to $0.176 \mathrm{Mg} \mathrm{ha}^{-1} / \mathrm{mm}$ in 2004 , when the highest yield was obtained (Table 2). The average value of the ETa/WUE coefficient was 0.187 $\mathrm{Mg} \mathrm{ha}^{-1} / \mathrm{mm}$, with values ranging from $0.159 \mathrm{Mg} \mathrm{ha}^{-1} / \mathrm{mm}$ in 2005 to $0.210 \mathrm{Mg} \mathrm{ha}^{-1} / \mathrm{mm}$ in 2004 (Table 2). Takac et al. (2008) reported in Slovakia the values of ETm/WUE and ETa/WUE of $0.098 \mathrm{Mg} \mathrm{ha}^{-1} / \mathrm{mm}$ and $0.115 \mathrm{Mg} \mathrm{ha}^{-1} / \mathrm{mm}$, respectively.

Table 2. Sugar beet yield $\left(\mathrm{Mg} \mathrm{ha}^{-1}\right)$ in irrigated $\left(\mathrm{T}_{\mathrm{I}}\right)$ and non-irrigated $\left(\mathrm{T}_{0}\right)$ conditions, precipitation $(\mathrm{P}, \mathrm{mm})$, and mean air temperatures $\left(\mathrm{T}^{0} \mathrm{C}\right)$ in the growing season, irrigation water applied (I, mm), ETm $(\mathrm{mm})$, ETa $(\mathrm{mm}), \mathrm{I} / \mathrm{WUE}\left(\mathrm{Mg} \mathrm{ha}^{-1} / \mathrm{mm}\right)$, ETm/WUE $\left(\mathrm{Mg} \mathrm{ha}^{-1} / \mathrm{mm}\right), \mathrm{ETa} / \mathrm{WUE}\left(\mathrm{Mg} \mathrm{ha}^{-1} / \mathrm{mm}\right)$

\begin{tabular}{|c|c|c|c|c|c|c|c|c|c|c|}
\hline \multirow{2}{*}{ Year } & \multicolumn{2}{|c|}{ Yield } & \multirow{2}{*}{$\mathrm{P}$} & \multirow{2}{*}{$\mathrm{T}$} & \multirow[t]{2}{*}{$\mathrm{I}$} & \multirow{2}{*}{ ETm } & \multirow{2}{*}{ ETa } & \multirow{2}{*}{$\begin{array}{c}\text { I } \\
\text { WUE }\end{array}$} & \multirow{2}{*}{$\begin{array}{l}\text { ETm } \\
\text { WUE }\end{array}$} & \multirow{2}{*}{$\begin{array}{c}\text { ETa } \\
\text { WUE }\end{array}$} \\
\hline & $\mathrm{T}_{\mathrm{I}}$ & $\mathrm{T}_{0}$ & & & & & & & & \\
\hline 2004 & 99.95 & 87.54 & 330 & 19.0 & 180 & 569 & 4417 & 0.080 & 0.176 & 0.210 \\
\hline 2005 & 88.09 & 84.79 & 496 & 18.6 & 135 & 534 & 534 & 0.024 & 0.165 & 0.159 \\
\hline 2006 & 94.00 & 85.05 & 354 & 19.5 & 180 & 602 & 440 & 0.050 & 0.156 & 0.193 \\
\hline Aver & $94.01 \mathrm{~ns}$ & $85.79 \mathrm{~ns}$ & 393 & 19.0 & 165 & 568 & 464 & 0.051 & 0.166 & 0.187 \\
\hline
\end{tabular}


The I/WUE coefficient values for maize and sugar beet obtained during study period, corresponded to weather conditions of the year, first of all to precipitation amounts and arrangement. Based on the comparison of the I/WUE values obtained in the study period with those from the literature, it can be concluded that a cost-effective irrigation schedule was designed, taking into account the water requirement of plants and waterphysical soil properties as well. The higher productivity of applied water of maize and sugar beet at non-irrigated, control model ( $\mathrm{T}_{0}-\mathrm{ETa} / \mathrm{WUE} 0.032,0.185 \mathrm{Mg} \mathrm{ha}^{-1} / \mathrm{mm}$ ) in relation to the values established in conditions with irrigation $\left(T_{I}-E T m / W U E ~ 0.031\right.$, $0.164 \mathrm{Mg} \mathrm{ha}^{-1} / \mathrm{mm}$ ) underlined the supplementary character of irrigation in Vojvodina. In the variable climate conditions of Vojvodina, where precipitation cannot be predicted for a long term, negative effect of irrigation may occur if it is done before a heavy rain, because in that case the soil may become over moisture, and the excess water may percolate into deep soil layers taking the nutrients with it. In such years, the effect of irrigation on maize and sugar beet yield may be negligible or altogether missing. Takac et al. (2008) also emphasized the supplementary character of irrigation in Slovakia, as well as higher ETa/WUE $\left(0.187 \mathrm{Mg} \mathrm{ha}^{-1} / \mathrm{mm}\right)$ than ETm/WUE $\left(0.166 \mathrm{Mg} \mathrm{ha}^{-1} / \mathrm{mm}\right)$ values for sugar beet, attributing the differences to the fact that sometimes precipitation combined with irrigation do not contribute to higher water productivity.

\section{Conclusions}

The experimental results obtained in this study clearly underline vital importance of efficiency of water applied in irrgated agriculture and confirm that only properly managed agro-ecosystem were capable to resist the pressure of production demand and responded with resilience to applied cropping technology over the years.

\section{References}

Al-Kaisi M. M. - Yin M.: 2003. Effects of Nitrogen Rate, Irrigation Rate, and Plant Population on Corn Yield and and Water Use Efficiency. Agron. J., 95:1475-1482.

Berzsenyi Z.: 2009. New challenges approaches for crop production research. Növénytermelés, 58:1. 77-91.

Bošnak Dj.: 1982. Evaporacija sa slobodne vodene površine kao osnova zalivnog režima i njen odnos prema ETP kukuruza i soje. Doktorska disertacija. Poljoprivredni fakultet Novi Sad.

Bos M.G.: 1998. Summary of ICID definitions of irrigation efficiency. ICID Bull. 34: 28-31.

Dragović S.: 2000. Navodnjavanje. Naučni institut za ratarstvo i povrtarstvo Novi Sad, str. 179.

Draycott A.P.: 2006. Sugar beet. World Agriculture Series, Blackwell Publishing Ltd, p: 232.

Eswaran H.: 1993. Soil resilience and sustainable land management in the context of Agenda 21. In: Soil and Sustainable Land Use, eds. Greenland D.J. - Szabolcs I., Wallingford: CABI, 21-32.

Hook J.E.: 1985. Irrigated corn management for the costal plain: Irrigation scheduling and response to soil water and evaporative demand. Univ. Georgia Agric. Sci. Agron. Res. Pep. AY, 1-86.

Howel T.A. - Schneider A.D. - Evett, S.R.: 1997. Subsurface and surface microirrigation of corn - Southern High Plains. Trans. ASAE 40: 635-641.

Kavazza L.: 1976. Problems in irrigation at farm and field levels. IV International Symposium on Water Supply and Irrigation in the Open and Under Protected Cultivation. Acta Hort., 228: 78-93.

Kenan U. - Cafer G.: 2004. The Effect of Water Deficit on Yield and Yield Components of Sugar Beet. Turk. J. Agric. For. 28: 163-172.

Mahmoodi R. - Maralian H. - Aghabarati A.: 2008. Effects of limited irrigation on root yield and quality of sugar beet (Beta vulgaris L.). African Journal of Biotechnology, 7: 24, 4475-4478.

Takac J. - Nejedlik P. - Siska B.: 2008. Adagio, Cecilia, COST734 workshop, Jois, AT, Oct. 6-8

Werker A. R. - Jaggard K.W.: 1998. Dependence of sugar beet yield on light interception and evapotranspiration. Agric. Forest Meteorol., 89: 229-240. 